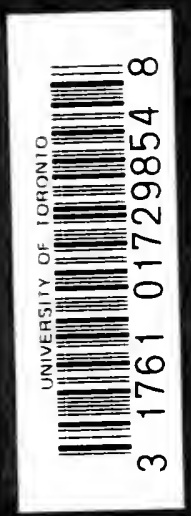

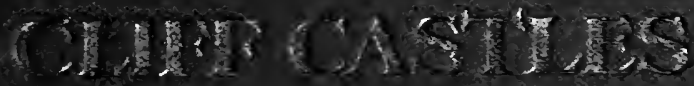

$$
\begin{aligned}
& \text { ANon: } \\
& \text { CANDE DWWUINUNGS } \\
& \text { G1351201\% }
\end{aligned}
$$

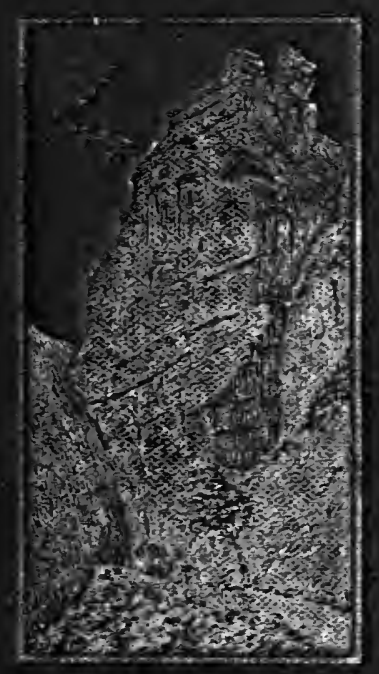

6. BARMa-comon 

CLIFF CASTLES AND CAVE DWELLINGS OF EUROPE 


\section{Cliff Castles and Cave Dwellings}

of Europe.

By S. BARing-Gould, M.A., Author of "Family Names and their Story," "The Tragedy of the Casars," "Curi. ous Myths of the Middle Ages," $\mathcal{S}^{2}$. With 54 Illustrations and Diagrams. Demy 8vo., I2s. 6d. net.

Seventeen Years Among the Sea Dyaks of Borneo.

A Record of Intimate Association with the Natives of the Bornean Jun. gles. By Edwin H. Gomes, M.A., Aushor of "The Sea Dyaks of Borneo," $\mathcal{E}^{*}$ c. With an Introduction by the Rev. John Perham, formerly Archdeacon of Singapore. With 40 Illustrations and a Map. Demy 8vo., 16s.

Among the Rajahs and Ryots of Northern India.

A Civil Servant's Recollections and Impressions of Thirty-seven Years of Work and Sport in the Central Provinces and Bengal. By Sir ANDrEw H. L. FRASER, K.C.S.I.,M.A., LL.D.; late Lieutenant-Governor of Bengal. With 34 Illustrations and a Map. Demy 8vo., 18 s.

\section{Second Edition.}

Fighting the Slave-Hunters in Central Africa.

A Record of Twenty-six Years of Travel and Adventure round the Great Lakes, and of the Overthrow of Tip-pu-tib, Rumaliza, and other Great Slave-traders. By Alfred J. Swans. With 45 Illustrations and a Map. Demy 8vo., 16s. net.

"This is an extraordinarily fascinating book."-Athenaum.

Family Names and their Story. By S. Baring-Gould, M.A. Demy 8 vo., $7 \mathrm{~s}$. $6 \mathrm{~d}$. net.

"This most entertaining of volumes."-Evening Standard.

\section{Third Edition.}

Among the Wild Tribes of the Afghan Frontier.

A Record of Sixteen Years' Close Intercourse with the Natives of the Indian Marches. By T. L. Pennele, M.D., B.Sc. F.R.G.S. With an Introduction by LORD ROBERTS, V.C. With 37 Illustrations and two Maps. Demy 8vo., x6s. net.

"This interesting and valuable book."-Manchestir Guardian.

The Childhood of Man.

A Popular Account of the Lives, Customs, and Thoughts of the Primitive Races. By Dr. Len Frobenius. Translated by Prof. A. H. KEANR, LL.D., F.R.G.S. With 4r5 Illustrations. Demy 8vo., I6s. net.

"The general reader will find much that is entertaining in "The Childhood of Man,' while the student cannot afford to overlook it." -Dr. A. C. Hadvon in The Nation. 
Digitized by the Internet Archive in 2007 with funding from Microsoft Corporation 


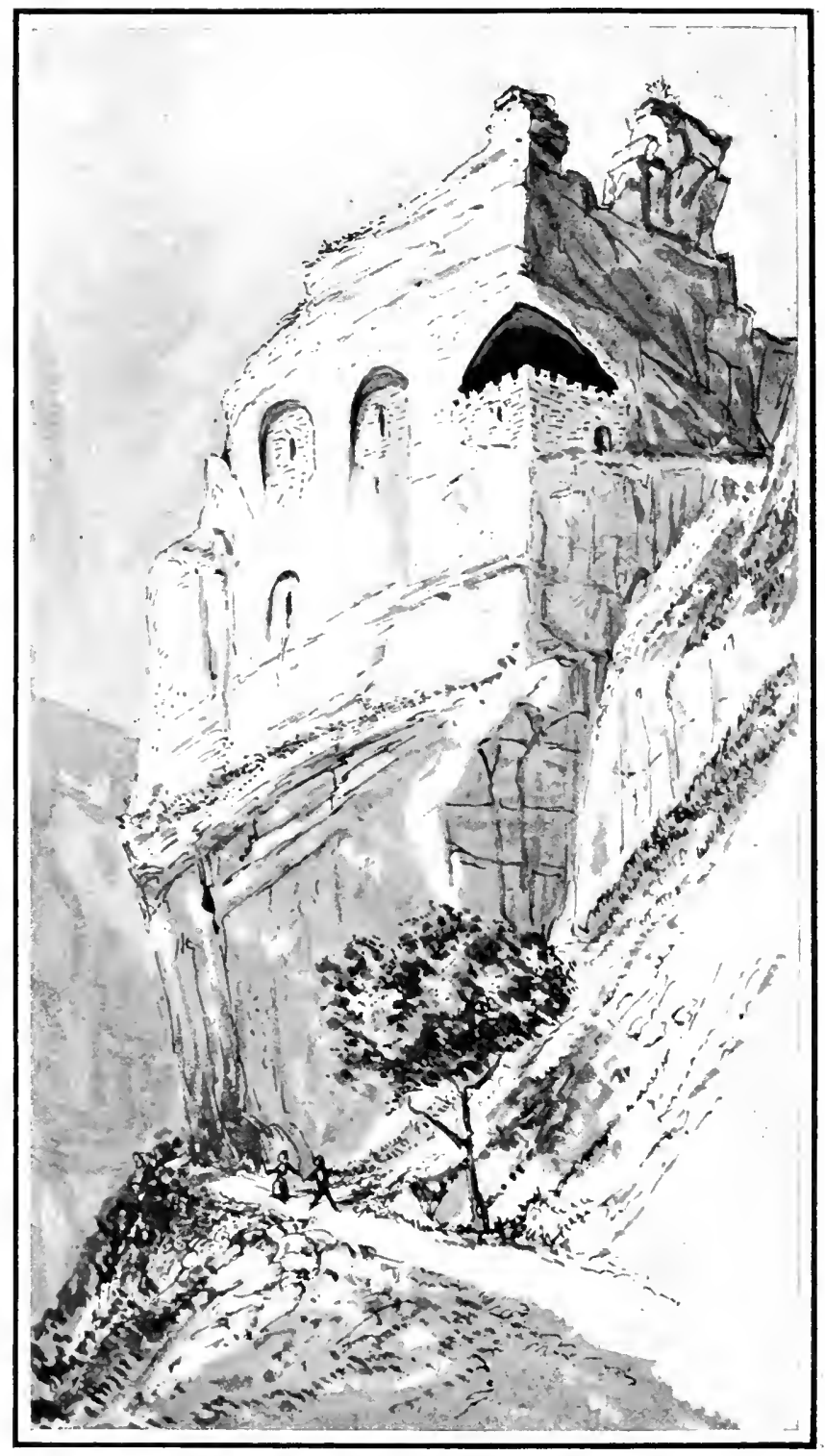

Cliff-Castle, Brengues

S. B.G.

In this castle the Bishop of Cahors took refuge from the English, to whom he refused to submit, and in it he died in 1367 . It was however captured by the English in 1377. 


\title{
CLIFF CASTLES AND CAVE DWELLINGS OF EUROPE
}

\author{
BY \\ $2 b^{2}$ \\ S. BARING-GOULD, M.A. \\ ACTHOR OF \\ "FAMILY NAMES \& THEIR STORY," "THE TRAGEDY OF THE CESARS, \\ "CURIOU'S MYTHS OF THE MIDDLE AGES," EC. E-C.
}

("The house it the rock

CrMbeline III. 3 .

WITH 5I ILLUSTRATIONS \& DIAGRAMS

LONDON

SEELEY AND CO. LIMITED

38 GREAT RUSSELL STREET

I9II 


\title{
FAMILY NAMES \& THEIR STORY
}

\author{
By the REv, S. BARING-GOULD, M.A.
}

\section{Demy 8vo, 7s. 6d. net}

"There can scarcely be a name that does not find its history chronicled in this exhaustive, picturesque and amusing volume." -Evening Standard.

"Extremely interesting and suggestive; written on popular lines and in lively style."-Scotsman.

"No living writer is more competent to deal with this subject than Mr. Baring-Gould."-Chutch Family Newspaper.

"An immense mass of detailed information."-Times.

"This most entertaining of volumes; of absorbing human interest."-Evening Standard.

"We might wander for hours among Mr. Baring-Gould's pleasant and instructive pages, and we heartily commend them to any one who wants to know what his own name means, or how much of the history of the country is enshrined in those of his friends."-Globe.

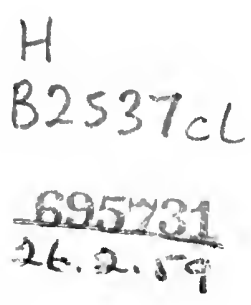




\section{P R E F A C E}

T THEN in 1850 appeared the Report of the Secretary of War for the United States, containing Mr. J. H. Simpson's account of the Cliff Dwellings in Colorado, great surprise was awakened in America, and since then these remains have been investigated by many explorers, of whom I need only name Holmes" "Report of the Ancient Ruins in South-West Colorado during the Summers of 1875 and 1876," and Jackson's "Ruins of South-West Colorado in 1875 and 1877." Powell, Newberry, \&c., have also described them. A summary is in "Prehistoric America," by the Marquis de Nadaillac, 1885 , and the latest contribution to the subject are articles in Scrilmer's Magasine by E. S. Curtis, 1906 and 1909.

The Pueblos Indians $d$ well for the most part at a short distance from the Rio Grande; the Zuñi, however, one of their best known tribes, are settled far from that river, near the sources of the Gila. In the Pueblos country are tremendous cañons of red sandstone, and in their sides are the habitations of human beings perched on every ledge in inaccessible positions. Major Powell, United States Geologist, expressed his amazement at seeing nothing for whole days but perpendicular cliffs everywhere riddled with human dwellings resembling the cells of a honeycomb. The apparently inaccessible heights were scaled by means of long poles with lateral teeth disposed like the rungs of a ladder, and inserted at intervals in notches let into the face of the perpendicular rock. The most curious of these dwellings, compared to which the most Alpine chalet is of easy access, 


\section{PREFACE}

have ceased to be occupied, but the Maqui, in North-West Arizona, still inhabit villages of stone built on sandstone tables, standing isolated in the midst of a sandy ocean almost destitute of vegetation.

The cause of the abandonment of the cliff dwellings has been the diminished rainfall, that rendering the land barren has sent its population elsewhere. The rivers, the very streams, are dried up, and only parched water-courses show where they once flowed.

"The early inhabitants of the region under notice were wonderfully skilful in turning the result of the natural weathering of the rocks to account. To construct a cavedwelling, the entrance to the cave or the front of the open gallery was walled up with adobes, leaving only a small opening serving for both door and window. 'The cliff houses take the form and dimensions of the platform or ledge from which they rise. The masonry is well laid, and it is wonderful with what skill the walls are joined to the cliff, and with what care the aspect of the neighbouring rocks has been imitated in the external architecture." 1

In Asia also these rock-dwellings abound. The limestone cliff's of Palestine are riddled with them. They are found also in Armenia and in Afghanistan. At Bamian, in the latter, "the rocks are perforated in every direction. A whole people could put up in the "Twelve Thousand Galleries' which occupy the slopes of the valley for a distance of eight miles. Isolated bluffs are pierced with so many chambers that they look like honeycombs." 2

That Troglodytes have inhabited rocks in Africa has been known since the time of Pliny.

But it has hardly been realised to what an extent similar cliff dwellings have existed and do still exist in Europe.

1 Nadaillac, "Prehistoric America," Lond. 1885, p. 205.

2 Reclus, "Asia," iii. p. 245. 


\section{PREFACE}

In 1894, in my book, "The Deserts of Southern France," I drew attention to rock habitations in Dordogne and Lot, but $I$ had to crush all my information on this subject into a single chapter. The subject, however, is too interesting and too greatly ramified to be thus compressed. It is one, moreover, that throws sidelights on manners and modes of life in the past that cannot fail to be of interest. The description giren abore of cliff dwellings in Oregon might be employed, without changing a word, for those in Europe.

To the best of my knowledge, the theme of European Troglodytes has remained hitherto undealt with, though occasional mention has been made of those on the Loire. It has been taken for granted that care-dwellers belonged to a remote past in civilised Europe; but they are only now being expelled in Nottinghamshire and Shropshire, by the interference of sanitary officers.

Elsewhere, the race is by no means extinct. In France more people live underground than most suppose. And they show no inclination to leave their dwellings. Just one month ago from the date of writing this page, I sketched the new front that a man had erected to his paternal cave at Villiers in Loir et Cher. The habitation was wholly subterranean, but then it consisted of one room alone. The freshly completed face was cut in freestone, with door and window, and above were sculptured the aces of hearts, spades, and diamonds, an anchor, a cogwheel and a fish. Separated from this mansion was a second, divided from it by a buttress of untrimmed rock, and this other also was newly fronted, occupied by a neat and pleasant-spoken woman who was vastly proud of her cavern residence. "Mais c'est tout ce qu'on peut désirer. Enfin on s'y troure très bien." 



\title{
CONTENTS
}

\author{
CHAPTER I
}

\section{PREHISTORIC CAVE-DWELLERS}

Formation of chalk-Of dolomitic limestone-Where did the first men live-Their Eden in the chalk lands-Migration elsewhere - Pit dwellings - Civilisation stationary-TroglodytesAntiquity of man-Les Eyzies-Hôtel dn Paradis-The first colonists of the Vézère Valley-Their artistic accomplishments -Painting and sculpture-Rock dwellings in Champagne-Of a later period-Civilisation does not progress uniformly-The earth - Book of the Revelation of the past-La Langerie Basse - Blandas - Conduché - Grotte de Han - The race of Troglodytes not extinct

\section{CHAPTER II}

\section{MODERX TROGLODYTES}

Troglodytes of the Etang de Berre-The underground town of $\mathrm{Og}$, King of Bashan-Troo-Sanitation-Ancient mode of disposing of refuse-The talking well-Les Roches-Château de Bandan -Chapel of S. Gervais-La Grotte des Vierges-RochambeauLe Roi des Halles-La Roche Corbon-Human refuse at EzySaumar-Are there still pagans among them? - BourréCourtinean - The basket-makers of Villaines - Grioteanx Sauliac-Cuzorn-Brantôme-La Roche Beaucourt-TheSwabian Alb-Sibyllen loch-Vrena Beutlers Höhle-SchillingslochSchlössberg Höhle-Rock village in Sicily-In the CrimeaIn Egypt-In volcanic breccia-Balmes de Montbrun-Grottoes de Boissière-Grottoes de Jonas-The rock Ceyssac-The sandstone cave-dwellings of Corrèze-Their internal arrangementCluseanx-Care-dwellings in England-In NottinghamshireIn Staffordshire-In Cornwall-In Scotland-The sarage in man-Reversion to savagery-The Gubbins-A stone-cutterDaniel Gumb-A gentleman of Sens-Toller of Clun Downs . 30-69

\section{CHAPTER III}

\section{SOUTERRAINS}

Prussian invasion of Bohemia - Adersbach and Wickelsdorf labyrinths-Refuges of the Israelites-Gauls suffocated in caves by Cæasar-Armenians by Corbulo-Story of Julius SabinusSaracen invasion-The devastation of Aquitaine by PepinRock refuges in Quercy-The Northmen-Persecution of the 


\section{CONTEN'TS}

Albigenses-The cave of Lombrive-The English domination of Guyenne-Two kinds of refuges-Saint Macaire-AlbanRefuge of Château Robin-Exploration-Methods of defence - Souterrain of Fayrolle-Of Saint Gauderic-Of Fauroux -Of Olmie - Aubeterre - Refuges under castles - Enormous number of souterrains in France-Victor Hugo's account of those in Brittany-Refuges resorted to in the time of the European War - Those in Picardy-Gapennes - Some comparatively modern-Condition of the peasantry during the Hundred Years' War-Tyranny of the nobles-Their barbarities -Refuges in Ireland - In England - The Dene Holes - at Chislehurst-At Tilbury-Their origin-Fogous in CornwallRefuges in Haddingtonshire - In Egg - Slaughter of the Macdonalds-Refuges in the Isle of Rathlin-Massacre by John Norris-Refuges in Crete-Christians suffocated in one by the Turks-Lamorcière in Algeria

\section{CHAPTER IV}

\section{CLIFF REFUGES}

Distinction between souterrain and cliff refuges-How these latter were reached-Cazelles-Peuch Saint Sour-Story of S. SourThe Roc d'Aucor - Exploration - How formerly reached Boundoulaou-Riou Ferrand-Cliff refuge near Brengues-Les Mées - Fadarelles - Puy Labrousse - Soulier-de-Chasteaux Refuges in Auvergne-Meschers-In Ariège-The Albigenses -Caves in Derbyshire-Reynard's cave-Cotton's cave-John Cann's cave-Elford's cave on Sheep's Tor . . . . 103-116

\section{CHAPTER V}

\section{ClifF CASTles. THE ROUTIERS}

The seigneural castle-Protection sought against the foes without and against the peasant in revolt-Instance of the Château Les Eyzies-Independence of the petty nobles-Condition of the country in France-In Germany-Weakness of the EmperorThe Raubritter-Italy-The nobles brought into the townsTheir towers-Division of the subject-Difference between the English manor-house and the foreign feudal castle-The English in France - The Hundred Years' War - Hopeless condition of the people-The Free Companies-How recruitedCrusade against the Albigenses-Barons no better than Routiers -Death of chivalry-Routiers were rarely Englishmen-Had no scruples as to whom they served-Disregarded treaties-The captains were Gascons or French-The nobles of the south on the English side-Nests in the rock-Depopulation and devastation-Insolence of the Companies-Bigaroque-Roc de TayacCorn-Roquefort-Brengues-The Bishop of Cahors dies thereChâteau du Diable at Cabrerets-Défilé des Anglais-Peyrousse -Les Roches du Tailleur-Trosky-The scolding women-The English not forgotten in Guyenne 


\section{CON'TEN'TS}

\section{CHAPTER VI}

\section{CLIFF CASTLES-Continued}

The difference between feudal castles and those of the RoutiersPAGES

Illustration of the character of the nobles-Two Counts of Perigord-The nobles in Auvergne- "Les grands Jours"-La Roche Saint Christophe-Surprised and destroyed-Reoccnpied by the Huguenots-Final destruction-La Roche Gageac-Its historyJean Tarde-Ravages of the Huguenots-Gluges-La Roche Lambert - Habichstein - Bürgstein - The spy-Kronmetz Corolo-Paxerloch-The shadowless man-Nottingham Castle -Arrest of Mortimer-Outmost castles-La Grotte de JiouxClovis crosses the Vienne-Le Gué du Loir-Antoine de Bourbon -Calvin at Saint Saturnin-His cave-La Roche Corail-Cave in which tbe "Institute of the Christian Religion" was written -Effects produced by this work-Preparation of Imen's minds for reform-Havoc wrought to art by the Calvinists-La Rochebrune-A cave-colander-Necessity for outlook stations-

Frontier fortifications . . . . . . . 142-172

\section{CHAPTER VII}

\section{SUBTERRATEAY CHURCHES}

Basilicas and catacumbal churches-Preference of the people for the latter-The cult of martyrs encouraged this-Crypts-Elevation of relics-Charch of SS. John and Paul on the Coelian HillTemples were originally sepulchres-Basilican churches converted into mausoleums-Dedications-Altars of wood changed for altars of stone-At first the bodies of martyrs were not dismembered-But dismemberment was made necessary by the transformation - The Martyrium of Poitiers - S. EmilionCarvings-Crypt-Aubeterre-A Huguenot stronghold-Orders issued by Jeanne d'Albret-Her extended powers-The mono. lithic church-Menaced by ruin-Rocamadour-Lirac-Mimet - Caudon-Natural cares used as churches-Gurat-LanmeurStory of S. Melor-Dolmen Chapel of the Seven Sleepers-Another at Cangas-de-Ones-Confolens-Subterranean churches in Egypt -In Crete-The sacred caves in Palestine-Revival of cave sanctuaries by the Crusaders-Springs of water in crypts . 173-195

\section{CHAPTER VIII}

\section{ROCK HERMITAGES}

Tibetian recluses-Christian hermits in Syria and Egypt-The Essenes and Therapentæ-Description by Philo of the latterBuddhist and Manichæan influence-Difference in motiveLikeness superficial-Possible necessity for the adoption of asceticism - Instance of extravagant asceticism in Syria- 


\section{CON'TENTS}

Extravagances in Ireland - In England - Early European solitaries-The Beatus Höhle-Grotto of S. Cybard-Decadence - Hermits in Languedoc-In Germany-A grocer hermitHermitage at S. Maurice-The Wild Kirchlein-The cave of S. Verena at Soleure-That of Magdalen at Freiburg-ObersteinHermitage at Brive-La Sainte Beaume-Sougé-VilliersMontserrat-Subiaco-La Vernia-Warkworth-Knaresborough -Robin Hood's stable-Roche-Anchor Church-Royston cave -Its carvings-Kindly remembrance of the hermit-The hermit a loss

\section{CHAPTER IX}

\section{ROCK MONASTERIES}

The hermits self-excommunicate-Liability to create a schismS. Paul-S. Mary of Egypt-S. Anthony-Enormous number of solitaries compels organisation into monasteries - Causes inducing flight to the desert-S. Athanasius at Trèves-Writes the "Life of S. Anthony"-Impulse given to flight from the world in the West-S. Martin-Desires to imitate the Lives of the Fathers of the Desert-At Poitiers-Founds Ligugé-Rock cells-Later history and ruin-Martin becomes Bishop of ToursFounds Marmoutier - History and ruin - Martin and the masqueraders-Present state-Baptistry-The Seven Sleepers -Brice elected bishop-Obliged to fly the see-Return and penance-Cave of S. Leobard-Abbey of Brantôme-Underground church-Other caves- " Papists' Holes" at Nottingham -Rock monastery of MIeteora-Der el Adra-Inkermann . 228-245

\section{CHAPTER $\mathrm{X}$}

\section{CAVE ORACLES}

Polignac-Greek oracles-Charonion-Cave of the Nymphs-Exhalations-Delos-Care of Trophonios-Experiences of Pausanius -Cave at Acharaca-Sibylline oracles-Destruction-Forged oracles-Oracles among the Jews-Story of Hallbjörn-Sounds issuing from caves-Echo-ELolian cave of Terni-Purgatory of S. Patrick-The Knight Owain-Visic by Sir William Lisle -By a monk of Eymstadt-Prohibited by Alexander VI.Prohibition rescinded by Pius III. - Destroyed in 1622-Revival of pilgrimages-Description by Gough-Friar Conrad-Lazarus Aigner-Roderic, King of the Goths-Sortes Sacra-Condemned by the Church-Nevertheless practised-Instances from Gregory of Tours-Incubation in pagan shrines-The cave of Cybele-Temples of Isis and Esculapius-Churches founded by Constantine dedicated to S. Michael-Incubation practiced in them-Instances-Churches of S. Cosmas and Damian-Practice at Caerleon-Superstition hard to kill-Grotto of Lourdes . 246-268 


\section{CONTENTS}

\section{CHAPTER XI}

\section{ROBBERS' DENS}

Humphrey Kynaston-His adventurous life-Cave at Ness CliffChinamen-David at Adullam-Bandit caves in PalestineLombrive-Surtshellir-Feruiden's cave-Gargas-La Crouzate -The baunts of Grettir-Dunterton-Precautions against burglary-Story of K. F. Masch-His capture-The Leichtweisböhle-Adersbach retreats-Babinsky-His capture . 269-294

\section{CHAPTER XII}

\section{ROCK SEPULCHRES}

Difference between the tombs of the Israelites and those of the Egyptians-The reason for this-Jewish catacombs at RomeChristian catacombs-Puticoli-Numerous catacombs-Those of Syracuse-Those of Paris-Crypts became vaults for kings and nobles-Desecration-That of Louis XI.-The instinct of immortality-Cave burials-In the Petit Morin-Scandinavian burials-Death regarded as suspended animation-Hervör at the cairn of Angantrr-The cairn-breaking of Gest-The barrow of Gunnar-Sigrun visits her husband in his cairn-The story of Asmund and Asvid-The same ideas in Christian timesMamertinus and Corcodemus-"De Miraculis Mortaorum"Ancestor worship-Persistence of usages derived from a remote antiquity-Neglect of thought of the dead-Double nature of man-The spiritual world-A walking postman-Conclusion 295-318

INDEX • • • • • . . . • • • 319-324 



\section{LIST OF ILLUSTRATIONS}

Cliff Castle, Brengues . . . . . . . . Frontispiece

PAGF

Cave Dwellers at Duclaik . . . . . . . . . 44

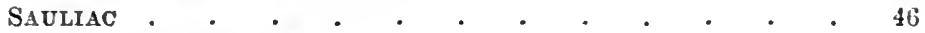

(Photo by GIRMA)

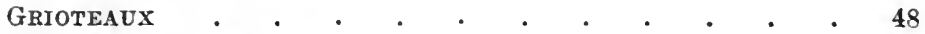

LA Rochebrune • • • . . . . . . . . . 48

Sketch Plax of Rock Stable, Commarques . . . 55

Plan of Rock Holes ix Nottingham PaRk . . . . 57

DRAKELOW . . . . . . . . . . . 60

AUbeterre . • • • . . . . . . . . 60

Play of the Refuge of Châtead Robin $\quad$ * . . . $\quad$ - 79

The Château of Fayrolles . . . . . . . . 83

Cluseau de Fauroux . . . . . . . . . . . . . 45

LA Roche Gageac . . . . . . . . . . 104

LE Peuch S. Sour . . . . . . . . . . 104

Caves of Meschers . . . . . . . . . . . . 112

Cave Refuge at Soulier de Chasteau . . . . . 112

Le Défilé des Axglais, Lot • • . . . . . 130

(Photo by BAUDEL, S. CÉRE)

Ch\&teau des Anglais, Breigues . . . . . . 132

Château du Diable, Cabrerets (Exterior) . . . . 132

" " " " • • • (INTERIOR) • 132

(Photo by BAUDEL, S. CÉRÉ)

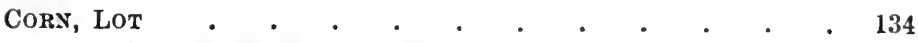

(Photo by BAUdel, S. CÉRÉ)

Château des Axglats, Autoire . . . . . . . 136

(Photo by Eacdec, S. Cérér)

Covolo . . . . . . . . . . . . . . . 138

LA Roche dU TAIlleUr . . . . . . . . . 138

KRONMET\%. . . . . 


\section{LIST OF ILIUSTRA'TIONS}

THR PUX PAGK

Tha PUXERLCH, STYRIA • • • • • • • • 152

Habichs'tein, Bohemia . . . . . . . . . 154

Rock Monastery, Nottingham Park . . . . 158

Rock Monastery, NottinghaM Park . . . . . 160

La Roche Coratl . • . • . . • • • • . 162

, " THE First HALL • • • • • • . . 162

GUE DE LOIR . . . . . . . . . . . . 164

LES RoChes . . . . . . . . . . . . . . . 164

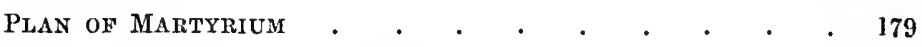

MoNolíthic ChurCh of S. EMILION • • . . • . 180

AubeterRe, Charente, Interior of Monolithic Church . 182

(Photo by Delagk)

Rocamadoul . . . . . . . . . . . . . . 184

(Photo by BAJdeL, S. CERÉ)

Aubeterre, Charente . . . . . . . . . . . 186

(Phato by DELAGE)

Subterranean Churcir, AUteterRe . . . . . . 188

(Photo by DrLage)!

Dolmen Chapel of the Seven Sleepers. . . . . 190

Plan of Dolmen Chapel near Plouarht • • . . 191

Plan of Chapel of S. Amadou . . . . . . . . . 215

ScUlpture in Royston CAVE . . . . . . . . 220

(Photo by R. H. ClaRK, Royston)

" " " • • • • • . . 222

(Photo by R. H. Clark, Royston)

ROYSTON CAVE • • • • • • • • • • • • • • • 226

(Photo by R. H. Clark, Royston)

Château de Rignac $\quad \cdot \quad \cdot \quad \cdot \quad \cdot \quad \cdot \quad \cdot \quad \cdot \quad \cdot \quad \cdot 226$

Le Trou Bourou . . . . . . . . . . . 234

Rock Baptisteir of St. Martin. . . . . . . 234

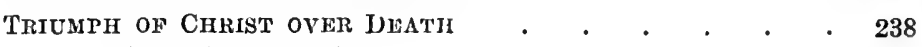

(Photo by LACRoIX)

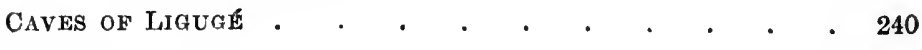

NesS ClIFF

Kynaston's Cave. . . . . . . . . . . . 268 


\title{
CLIFF CASTLES AND CAVE DWELLINGS OF EUROPE
}

\author{
CHAP'TER I \\ PREHISTORIC CAVE-DWELLERS
}

$\mathbf{N}$ a vastly remote past, and for a vastly extended period, the mighty deep rolled over the surface of a world inform and void, depositing a sediment of its used up living tenants, the microscopic cases of foraminiferæ, sponges, sea-urchins, husks, and the cast limbs of crustaceans. 'The descending shells of the diatoms like a subaqueous snow gradually buried the larger dejections. This went on till the sediment had attained a thickness of over one thousand feet. Then the earth beneath, heaved and tossed in sleep, cast off its white featherbed, projected it on high to become the chalk formation that occupies so distinct and extended a position in the geological structure of the globe. The chalk may be traced from the North of Ireland to the Crimea, a distance of about 11,140 geographical miles, and, in an opposite direction, from the South of Sweden to Bordeaux, a distance of 840 geographical miles.

It extends as a broad belt across France, like the sash of a Republican mayor. You may travel from Calais to Vendôme, to Tours, Poitiers, Angoulême, to the Gironde, and you are on chalk the whole way. It stretches through Central Europe, and is seen in North Africa. From the 


\section{PREHISTORIC CAVE-DWELLERS}

Crimea it reaches into Syria, and may be traced as far as the shores of the sea of Aral in Central Asia.

The chalk is not throughout alike in texture; hard beds alternate with others that are soft-beds with flints like plum-cake, and beds without, like white Spanish bread.

We are accustomed in England to chalk in rolling downs, except where bitten into by the sea, but elsewhere it is riven, and presents cliffs, and these cliffs are not at all like that of Shakespeare at Dover, but overhang, where hard beds alternate with others that are friable. These latter are corroded by the weather, and leave the more compact projecting like the roofs of penthouses. They are furrowed horizontally, licked smooth by the wind and rain. Not only so, but the chalk cliffs are riddled with caves, that are ancient water-courses. The rain falling on the surface is drunk by the thirsty soil, and it sinks till, finding where the chalk is tender, it forms a channel and flows as a subterranean rill, spouts forth on the face of the crags, till sinking still lower, it finds an exit at the bottom of the cliff, when it leaves its ancient conduit high and dry.

But before the chalk was tossed aloft there had been an earlier upheaval from the depths of the ocean, that of the Jurassic limestone. This was built up by coral insects working indefatigably through long ages, piling up their structures, as the sea-bottom slowly sank, straining ever higher, till at length their building was crushed together and projected on high, to form elevated plateaux, as the Causses of Quercy, and Alpine ranges, as the Dolomites of Brixen. But in the uplifting of this deposit, as it was inelastic, the strain split it in every direction, and down the rifts thus formed danced the torrents from higher granitic and schistous ranges, forming the gorges of the Tarn, the Ardêche, the Herault, the Gaves, and the Timée, in France. 


\section{PREHISTORIC CAVE-DWELLERS}

It has been a puzzle to decide which appeared first, the egg out of which the fowl was hatched, or the hen which laid the egg ; and it is an equal puzzle to the anthropologist to say whether man was first brought into existence as a babe or in maturity. In both cases he would be helpless. The babe would need its mother, and the man be paralysed into incapacity through lack of experience. But without stopping to debate this question, we may conclude that naked, shivering and homeless humanity would have to be pupil to the beasts to learn where to shelter his head. Where did man first appear? Where was the Garden of Eden? Indisputably on the chalk. There he found all his first demands supplied. The walls of cretaceous rock furnished him with shelter under its ledges of overhanging beds, flints out of which to fashion his tools, and nodules of pyrites wherewith to kindle a fire. Providence through aeons had built up the chalk to be man's first home.

Incontestably, the great centres of population in the primeval ages were the chalklands, and next to them those of limestone. The chalk first, for it furnished man with flints, and the limestone next when he had learned to barter.

He could have lived nowhere else, till, after the lapse of ages, he had developed invention and adaptability. Besant and Rice, in "Ready-money Mortiboy," speak of Divine Discontent as the motive power impelling man to progress. Not till the chalk and the limestone shelters were stocked, and could hold no more, would men be driven to invent for themselves other dwellings. The first men being sent into the world without a natural coat of fur or feathers, would settle into caves or under overhanging roofs of rock, and with flint picked out of it, chipped and pointed, secure the flesh of the beast for food and its hide for clothing. Having accomplished this, man would sit down complacently for long ages. Indeed, there are certain branches of the human 


\section{PREHISTORIC CAVE-DWELLERS}

family that have progressed no further and display no ambition to advance.

Only when the districts of chalk and limestone were overstocked would the overflow be constrained to look elsewhere for shelter. Then some daring innovators, driven from the favoured land, would construct habitations by grubbing into the soil, and covering them with a roof of turf. The ancient Germans, according to Tacitus, lived in underground cabins, heaped over with dung to keep them warm during the long winter. With the invention of the earthenware stove, the German Bauer has been enabled to rise above the surface; but he cherishes the manure round his house, so to speak, about his feet, as affectionately as when it warmed his head.

For a long time it was supposed that our British ancestors lived in pit dwellings, and whole clusters of them were recorded and mapped on the Yorkshire Wolds, and a British metropolis of them, Caer Penselcoit, was reported in Somersetshire. Habitations sunk deep in the rock, with only a roof above ground. But the spade has cracked these archæological theories like filberts, and has proved that the pits in the wolds were sunk after iron ore, or those in Somerset were burrowings for the extraction of chert. ${ }^{1}$ But the original paleolithic man did not get beyond the cavern or the rock-shelter. This latter was a retreat beneath an overhanging stratum of hard rock, screened against the weather by a curtain of skins. And why should he wish to change so long as these were available? We, from our advanced position, sitting in padded arm-chairs, before a coal fire, can see that there was room for improvement; but

1 Atkinson, "Forty Years in a Moorland Parish." Lond. 1891, p. 161, et seq. Some pits are, however, not so dubious. At Hurstbourne, in Hants, pit habitations have been explored ; others, in Kent and Oxfordshire, undoubtedly once dwelt in. In one of the Kentish pits 900 flakes and cores of flint were found. The Chysoyster huts in Cornwall and the "Picts houses" in Scotland were built up of stones, underground. 


\section{PREHISTORIC CAVE-DWELLERS}

he could not. The rock-dwelling was commodious, dry, warm in winter and cool in summer, and it cost him no trouble to fashion it, or keep it in repair. He had not the prophetic eye to look forward to the arm-chair and the coal fire. Indeed, at all periods, down to the present day, those who desire to lead the simple life, and those who have been reared in these nature-formed dwelling-places, feel no ambition to occupy stone-built houses. In North Devon the cottages are reared of cob, kneaded clay, and thatched. A squire on his estate pulled down those he possessed and built in their place brick houses with slated roofs. The cottagers bitterly resented the change, their old mud-hovels were so much warmer. And in like manner the primeval man would not exchange his abris for a structural dwelling unless constrained so to do.

The ancients knew that the first homes of mankind were grottoes. They wrote of Troglodytes in Africa and of cavedwellers in Liguria. In Arabia Petræea, a highly civilized people converted their simple rock-dwellings into sumptuous palaces.

I might fill pages with quotations to the purpose from the classic authors, but the reader would skip them all. It is not my intention to give a detailed account of the prehistoric cave-dwellers. They have been written about repeatedly. In 1882, Dr. Buckland published the results of his exploration of the Kirkdale Cave in Yorkshire in Reliquice Diluviance, and sought to establish that the remains there found pertained to the men who were swept away by Noah's flood. The publication of Sir Charles Lyall's "The Geological Evidences of the Antiquity of Man," in 1863, was a shock to all such as clung to the traditional view that these deposits were due to a cosmic deluge, and that man was created $400 t$ B.c.

At first the announcements proving the antiquity of man were received with orthodox incredulity, because, although 


\section{PREHISTORIC CAVE-DWELLERS}

the strata, in which the remains were found, are the most modern of all earth's formations, still the testimony so completely contravened traditional beliefs, that the most conclusive evidence was required for its proof. Such evidence has been found, and is so strong, and so cumulative in character as to be now generally accepted as conclusive.

Evidence substantiating the thesis of Lyall had been accumulating, and the researches of Lartet and Christy in the Vézère valley, published in 1865-75, as Reliquia Aquitanica, conclusively proved that man in Perigord had been a naked savage, contemporary with the mammoth, the reindeer and the cave-bear, that he had not learned to domesticate animals, to sow fields, to make pots, and that he was entirely ignorant of the use of the metals.

Since then, in the valley of the Vézère, Les Eyzies in the Department of Dordogne, has become a classic spot. I have already described it in another work, ${ }^{1}$ but I must here say a few more words concerning it. On reaching the valley of the Vézère by the train from Perigueux, one is swung down from the plateau into a trough between steep scarps of chalk-rock that rise from 150 to 300 feet above the placid river. These scarps have been ploughed by the weather in long horizontal furrows, so that they lean over as though desirous of contemplating their dirty faces in the limpid water. Out of their clefts spring evergreen oaks, juniper, box and sloe-bushes. Moss and lichen stain the white walls that are streaked by black tricklings from above, and are accordingly not beautiful-their faces are like that of a pale, dirty, and weeping child with a cold in its head, who does not use a pocket-handkerchief. Jackdaws haunt the upper ledges and smaller caves that gape on all sides chattering like boys escaped from school, and anon a raven starts forth and hoarsely calls for silence.

At the foot of the stooping crags, bowing to each other 1 "The Deserts of Southern France." Lond., Methuen, 1894. 


\section{PREHISTORIC CAVE-DWELLERS}

across the stream, lie masses that have broken from above, and atop and behind these is to be seen a string of cottages built into the rock, taking advantage of the overarching stratum of hard chalk; and cutting into it are russet, tiled roofs, where the cottagers have sought to expand beyond the natural shelter: they are in an intermediate position. Just as I have seen a caddis-worm emancipating itself from its cage, half in as a worm, half out as a fly.

Nature would seem to have specially favoured this little nook of France, which must have been the Eden of primeral man on Gallic soil. There he found ready-made habitations, a river abounding in fish, a forest teeming with game; constrained periodically to descend from the waterless plateaux, at such points as favoured a descent, to slake their thirst at the stream, and there was the nude hunter lurking in the scrub or behind a stone, with bow or spear awaiting his prey-his dinner and his jacket.

What beasts did he slay? The wild horse, with huge head, was driven by hin over the edge of the precipice, and when it fell with broken limbs or spine, was cut up with flint knives and greedily devoured. The reindeer was also hunted, and the cumbersome mammoth enabled a whole tribe to gorge itself.

The grottoes perforating the cliff, like bubbles in Gruyère cheese, have been occupied consecutively to the present day. Opposite to Les Eyzies, hanging like a net or skein of black thread to the face of the precipice, is a hotel, part gallery, part cave-l'Auberge du Paradis; and a notice in large capitals invites the visitor to a "Course aux Canards."

When I was last there, reaching the tavern by a ladder erected in a grotto, I learned that an American couple on their honeymoon had recently slept in the guest-chamber scooped out of the living rock. The kitchen itself is a cavern, and in it are shelves, staged against the rock, offering Chartreuse, green and yellow, Benedictine, and Crème de 23 


\section{PREHISTORIC CAVE-DWELLERS}

Menthe. The proprietor also possesses a gramophone, and its strident notes we may well suppose imitate the tones of the first inhabitants of this den. Of the Roc de Tayac, in and against which this paradisaical hotel is plastered, I shall have more to say in another chapter.

'The first men who settled in this favoured valley under shelters open to the blaze of the sun, in a soft and pleasant climate, where the air when not in proximity to men, is scented with mint, marjoram and juniper, where with little trouble a salmon might be harpooned, must have multiplied enormously-for every overhanging rock, every cavern, even every fallen block of stone, has been utilised as a habitation. Where a block has fallen, the prehistoric men scratched the earth away from beneath it, and couched in the trench. The ground by the river when turned up is black with the charcoal from their fires. A very little research will reward the visitor with a pocketful of flint knives and scrapers. And this is what is found not only on the main artery, but on all the lateral veins of waterwherever the cretaceous rocks project and invite to take shelter under them. Since the researches of Lartet and Christy, it has been known as an established fact that these savages were indued with rare artistic skill. Their delineations with a flint point on ivory and bone, of the mammoth, reindeer, and horse, are so masterly that these men stand forth as the spiritual ancestors of Landseer and Rosa Bonheur. And what is also remarkable is that the race which succeeded, that which discovered the use of metal, was deroid of the artistic sense, and their attempts at delineation are like the scribbling of an infant.

Of late years fresh discoveries have been made, revealing the fact that the Paleolithic men were able to paint as well as to engrave. In Les Combarelles and at Font-de-Gaume, far in the depths, where no light reaches, the walls have been found turned into a veritable picture-gallery. In 21 


\section{PREHISTORIC CAVE-DWELLERS}

the latter are twenty-four paintings; in the former forty-two.

Doctor Capitan and the Abbé Breuil were the first to discover the paintings in Les Combarelles. In an account read before the Academy of Sciences, they say: "Most frequently, the animals whose contours are indicated by a black outline, have all the surface thus circumscribed, entirely covered with red ochre. In some cases certain parts, such as the head of the urochs, seems to have been painted over with black and red together, so as to produce a brown tint. In other cases the head of the beast is black, and the rest of the body brown. This is veritable fresco painting, and the colour was usually applied after the outline had been graven in the stone. At other times some shading is added by hatching supplied after the outline had been drawn. Finally, the contours are occasionally thrown into prominence by scraping away the surface of the rock around, so as to give to the figures the appearance of being in low relief."

These wall paintings are by no means unique. They have been found as well at Pair-sur-Pair in Gironde, and in the grotto of Altamira at Santillana del Mar, in the north of Spain.

Still more recently an additional revelation as to the artistic skill of primeval man has been made: in a cave hitherto unexplored has been discovered actual sculpture with rounded forms, of extinct beasts.

These discoveries appeared incredible, first, because it was not considered possible that paintings of such a vastly remote antiquity could remain fresh and distinguishable, and secondly, because it was not thought that paintings and sculpture could be executed in the depths of a rayless cavern, and artificial light have left no traces in a deposit of soot on the roof.

But it must be remembered that these subterranean 


\section{PREHISTORIC CAVE-DWELLERS}

passages have been sealed up from time immemorial, and subjected to no invasion by man or beast, or to any change of air or temperature. And secondly, that the artists obtained light from melted fat in stone bowls on the floor, in which was a wick of pith; and such lamps would hardly discolour ceiling or walls. Of the genuineness of these paintings and sculptures there can be no question, from the fact that some are partly glazed over and some half obliterated by stalagmitic deposits.

Another discovery made in the Mas d'Azil in Arriege, is of painted pebbles and fan-shells that had served as paintpots. ${ }^{1}$ The pebbles had been decorated with spots, stripes, zig-zags, crosses, and various rude figures; and these were associated with paleolithic tools. In the chalk of Champagne, where there are no cliffs, whole villages of underground habitations have been discovered, but none of these go back to the earliest age of all; they belong to various epochs; but the first to excavate them was the Neolithic man, he who raised the rude stone monuments elsewhere. He had learned to domesticate the ox and the sheep, had made of the dog the friend of man. His wife span and he delved; he dug the clay, and she formed it with her fingers into vessels, on which to this day her finger-prints may be found.

These caves are hollowed out in a thick bed of cretaceous rock. The habitations are divided into two unequal parts by a wall cut in the living chalk. To penetrate into the innermost portion of the cave, one has to descend by steps cut in the stone, and these steps bear indications of long usage. The entrance is hewn out of a massive screen of rock, left for the purpose, and on each side of the doorway the edges show the rebate which served to receive a wooden door-frame. Two small holes on the right and left were used for fixing bars across to hold the door fast. A good

1 Piette (E.), Les Galets colorrés du Mas d'Azil. Paris, 1896. 


\section{PREHISTORIC CAVE-DWELLERS}

many of these caves are provided with a ventilating shaft, and some skilful contrivances were had recourse to for keeping out water. Inside are shelves, recesses cut in the chalk, for lamps, and to serve as cupboards. But probably these are due to later occupants. The Baron de Baye, who explored these caves, picked up worked flints, showing that their primitive occupants had been men of the prehistoric age, and other caves associated with them that were sepulchral were indisputably of the Neolithic age. ${ }^{1}$

Mankind progresses not smoothly, as by a sliding carpet ascent, but by rugged steps broken by gaps. He halts long on one stage before taking the next. Often he remains stationary, unable to form resolution to step forward ; sometimes even has turned round and retrograded.

The stream of civilisation flows on like a river, it is rapid in mid-current, slow at the sides, and has its backwaters. At best, civilisation advances by spirals. The native of New Guinea still employs stone tools; whilst an Englishman can get a nest of matches for twopence, an Indian laboriously kindles a fire with a couple of sticks. The prehistoric hunter of Solutré devoured the horse. In the time of Horace so did the Concanni of Spain. In the reign of Hakon, Athelstan's foster son, horseflesh formed the sacrificial meal of the Norseman. At the present day, as Mr. Lloyd George assures us, the haggard, ill-paid German mechanic breaks his long fast on black bread with rare meals of horseflesh.

At La Laugerie Basse, on the right bank of the Vézère, is a vast accumulation of fallen rocks, encumbering the ground for at least thirty-five feet in height under the overhanging cornice. 'Ihe fallen matter consists of the disintegration of the projecting lip. Against the cliff, under the shelter of the rock, as already said, are cottages with lean-to roofs, internally with the back and with at

${ }^{1}$ De Baye (J.), L'Archéologie préhistorique. Paris, 1888. 


\section{PREHISTORIC CAVE-DWELLERS}

least half the ceiling composed of the rock. In one of these Lartet and Christy began to sink a pit, beside the owner's bed, and the work was carried on to conclusion by the late Dr. Massenat. 'The well was driven down through successive stages of Man; deposits from the sous dropped and trampled into the earth floor by the children of the cottagers till the virgin soil was reached; and there, lying on his side, with his hands to his head for protection, and with a block of fallen rock crushing his thigh, lay the first prehistoric occupant of this shelter.

On the Causse de Larzac is Navacelles, in Gard; you walk over the arid plain with nothing in sight; and all at once are brought to a standstill. You find yourself at the edge of a crater 965 feet deep, the sides in most places precipitous, and the bottom is reached only by a zig-zag path. In the face of one of the cliffs is the grotto of Blandas, that has been occupied since remote ages. A methodical exploration has revealed a spearhead of silex, a bronze axe, bone bracelets, a coin of the Hundred Years' War, and lastly a little pin-cushion of cloth in the shape of a heart, ornamented with metal crosses, the relic of some refugee in the Reign of 'Terror', hiding to escape the guillotine.

At Conduché, where the Célé slides into the Lot, high up in the yellow and grey limestone precipice is a cave, now accessible only by a ladder. Hither ascended a cantonnier when the new road was made up the valley, and here he found chipped flints of primeval man, a polished celt, a scrap of Samian ware, and in a niche at the side sealed up with stalactite, a tiny earthenware pitcher $2 \frac{1}{2}$ inches high, a leaden spindle-whorl, some shells, and a toy sheep-bell. Here a little shepherdess during the stormy times, when the Routiers ravaged the country, had her refuge while she watched her flock of goats, and here made her doll's house.

The stalactite cavern of Han in the Ardennes is visited 28 


\section{PREHISTORIC CAVE-DWELLERS}

yearly by crowds. You may see highly coloured illustrations of its interior illumined by Bengal lights in all the Belgian and many of the French railway stations. What is now a peepshow was in past ages a habitation and a home. In it the soil in successive layers has revealed objects belonging to successive periods in the history of mankind. Its floor has been in fact a Book of the Revelation of the Past, whose seals have been opened, and it has disclosed page by page the history of humanity, from the present, read backwards to the beginning.

At the bottom of all the deposits were discovered the remains of the very earliest inhabitants, with their hearths about which they sat in nudity and split bones to extract the marrow, trimmed flints, worked horn, necklaces of pierced wolf and bears' teeth; then potsherds formed by hand long before the invention of the wheel; higher up were the arms and utensils of the bronze age, and the weights of nets. Above these came the remains of the iron age and wheel-turned crocks. A still higher stratum surrendered a weight of a scale stamped with an effigy of the crusading king, S. Louis (1226-1270), and finally francs bearing the profile of a king, the reverse in every moral characteristic of Louis the Saint-that of Leopold of Congo notoriety. 


\section{CHAP'TER II}

\section{MODERN TROGLODY'TES}

$\mathrm{H}$

ERODOTUS, speaking of the Ligurians, says that they spent the night in the open air, rarely in huts, but that they usually inhabited caverns. Every traveller who goes to the Riviera, the old Ligurian shore, knows, but knows only by a passing glance, the Etang de Berre, that inland sea, blue as a sapphire, waveless, girt about by white hills, and perhaps he wonders that 'Toulon should have been selected as a naval port, when there was this one, deeper, and excavated by Nature to serve as a harbour. 'The rocks of S. Chamas that look down on this peaceful sheet of water, rarely traversed by a sail, are riddled with caves, still inhabited, as they were when Herodotus wrote 450 years before the Christian era.

The following account of an underground town in Palestine is from the pen of Consul Wetzstein, and describes one in the Hauran. "I visited old Edrei-the subterranean labyrinthic residence of King $\mathrm{Og}$ - on the east side of the Zanite hills. Two sons of the sheikh of the village-one fourteen and the other sixteen years of age-accompanied me. We took with us a box of matches and two candles. After we had gone down the slope for some time, we came to a dozen rooms which, at present, are used as goat stalls and storerooms for straw. The passage became gradually smaller, until at last we were compelled to lie down flat and creep along. This extremely difficult and uncomfortable progress lasted for about eight minutes, when we were obliged to jump down a steep well, several feet in depth. 30 


\section{MODERN 'TROGLODY'TES}

Here I noticed that the younger of my two attendants had remained behind, being afraid to follow us; but probably it was more from fear of the unknown European than of the dark and winding passages before us.

"We now found ourselves in a broad street, which had dwellings on both sides, whose height and width left nothing to be desired. The temperature was mild, the air free from unpleasant odours, and I felt not the smallest difficulty in breathing. Further along there were several cross-streets, and my guide called my attention to a hole in the ceiling for air, like three others which I afterwards saw, now closed from above. Soon after we came to a market-place, where, for a long distance, on both sides of the pretty broad street, were numerous shops in the walls, exactly in the style of the shops seen in Syrian cities. After a while we turned into a side street, where a great hall, whose roof was supported by four pillars, attracted my attention. 'The roof, or ceiling, was formed of a single slab of jasper, perfectly smooth and of immense size, in which $I$ was unable to perceive the slightest crack.

"The rooms, for the most part, had no supports. The doors were often made of a single square stone, and here and there $I$ also noticed fallen columns. After we had passed several cross-alleys or streets, and before we had reached the middle of the subterranean city, my attendant's light went out. As he was lighting again by mine, it occurred to me that possibly both our lights might be extinguished, and I asked the boy if he had any matches. 'No,' he replied, 'my brother has them.' 'Could you find your way back if the lights were put out?' 'Impossible,' he replied. For a moment I began to be alarmed at this underworld, and urged an immediate return. Without much difficulty we got back to the marketplace and from hence the youngster knew the way well enough. Thus, after a sojourn of more than an hour 31 


\section{MODERN 'TROGLODY'TES}

and a half in this labyrinth, I again greeted the light of day." 1

I have quoted this somewhat lengthy account because, as we shall see in the sequel, the subterranean dwellings and above all refuges in Europe, bear to this town of King $\mathrm{Og}$ of Bashan a marked resemblance.

Within four hours of Paris by Chartres and Sargé is the town of Montoire with a clean inn, Le Cheval Rouge, and next station down the Loir is 'l'rôo. The Loir, male, is the river, not La Loire of the feminine gender. Le Loir is a river that rises in the north-east, traverses the fertile upland plain of Beauce, and falls into and is lost in La Loire at Angers. It is a river rarely visited by English tourists, but it does not deserve to be overlooked. It has cut for itself a furrow in the chalk tufa, and the hospitable cliffs on each side offer a home to any vagrant who cares to scratch for himself a hole in the friable face, wherein to shelter his head.

Trôo bears a certain resemblance to the city of $\mathrm{Og}$. Originally it was all underground, but in process of time it effervesced, bubbled out of its holes, and is now but half troglodyte. The heights that form the Northern ideclivity of the valley of the Loir come to an abrupt end here, and have been sawn through by a small stream creating a natural fosse, isolating the hill of Trôo that is attached to the plateau only on the North. The hill rises steeply from the river to a crest occupied by a Romanesque church recently scoured to the whiteness of flour, and beside it is a mighty tumulus, planted with trees.

Formerly on this same height stood a castle, but this has been so completely broken down that nothing remains of it but a few substructures and its well.

Trôo was at one time a walled town, and as it was the key to the valley of the Loir, was hotly contested between

1 Reisebericht in Hauran, ii., pp. 47-48. 


\section{MODERN TROGLODY'TES}

the English and French during three hundred years, and later, between Catholics and Huguenots. The place was besieged by Mercader, the captain under Richard Cœur-deLion, who had flayed alive the slayer of his master under the walls of Caylus, although Richard had promised him immunity. Here Mercader met his death, and was buried under a mound that is still shown.

But what makes Trôo especially interesting is that the whole height is like a sponge, perforated with passages giving access to halls, some of which are circular, and into store-chambers; and most of the houses are wholly or in part underground. The caves that are inhabited are staged one above another, some reached by stairs that are little better than ladders, and the subterranean passages leading from them form a labyrinth within the bowels of the hill, and run in superposed storeys. In one that I entered was an oven, with a well at its side. A little further, in a large hall, a circular hole in the floor unfenced gave access by rope or ladder to a lower range of galleries. Any one exploring by the feeble light of a single candle, without a guide, might be precipitated down this abyss without knowing that there was a gaping opening before him. A long ascending passage, with niches in the sides for lamps, leads to where the fibres of the roots of the trees on the mound above have penetrated and are hanging down. It is said that the gallery led on to the castle, but since this latter has been ruined it has been blocked. In the holes whence flints have dropped spiders harbour, that feed on ghostly moths which flit in the pitch darkness, and when caught between the fingers resolve themselves into a trace of silver dust. But on what did these spectral moths feed? A pallid boy of sixteen who guided me about the town told me that he had been born in a cave; that he slept in one every night, and worked underground all day. His large brown eyes could see objects in the dark where all was of 33 


\section{MODERN 'TROGLODY'TES}

the crags, and the church has to curl itself like a dog going to sleep to fit the area allowed it. This rock forms perpendicular bluffs of chalk tufa, and masses of fallen stone lie at their fect. Some rocks overhang, and the whole of this cliff and the fallen blocks have been drilled with openings and converted into habitations for man and for beast. Doors and windows have been cut in the stone, which has been hollowed out as maggots clear out the kernel of a nut. Rooms, kitchens, cellars, stables have been thus contrived. The chimneys run up the rocks, and through them; and on the plateau above open as wells, but are surrounded by a breastwork of bricks to protect them against the rain, which night form a rill that would decant playfully down the opening in a waterfall. In winter, when all hearths are lighted, the smoke issuing from all these little structures has the effect of a series of steaming saucepans.

A little way up the river outside the walls is the Chatean de Boydan, half scooped out of the cliff, with pretty sixteenth century mullioned and transomed windows. At right angles to the rock a wing was thrown out to contain the state apartments with their fireplaces and chimneys. But unfortunately it was tacking on of new cloth to the old garment, and the face of the rock slid down carrying with it the side walls and windows, and has left the gable containing the handsome stone chimney-pieces and the chimneys as an isolated fragment. Just beyond, excavated in the bluff, is the chapel of S. Gervais, consisting of two portions, an outer and an inner chamber. But the cliff face had been cut for the windows too thin, and the whole slid away at the same time probably as the disaster happened to the castle, and has exposed the interior of this monolithic church. There are remains of frescoes on the wall painted with considerable spirit; a king on horseback blowing a hoin, and behind him a huntsman armed with 


\section{MODERN TROGLODYTES}

a boar-spear. Benches cut in the rock surround the sanctuary. Externally a niche contains a rude image of the saint.

Still nearer to Montoire, on the left bank of the Loir is Lavardin; high up on the side of the hill, completely screened by a dense wood, is a hamlet of Troglodytes. The principal excavation served originally as a hermitage, and is called La Grotte des Vierges. There is a range of rockdwellings in connection with it, some inhabited and some abandoned. The Grotte des Vierges is entered by steps descending into the principal chamber that is lighted by a window and is furnished with a fireplace. At one of the angles is a circular pit, six feet deep, with a groove at top for the reception of a cover. This was a silo for grain. From the first chamber entrance is obtained to a second much larger, that has in it a fireplace as well, and a staircase leading into a little oratory in which is an altar. The same staircase communicates with a lower chamber, probably intended as a cellar, for though the hernit might be frugal in meat there was no ban on the drink. The rock-dwelling nearest to the Grotte des Vierges on the left hand was of considerable proportions and pretence. It consisted of large halls, and was in several stages. The windows are broken away, the floors are gone, and it is reduced to a wreck. Below this series of cave-dwellings is the Fountain of Anduée of crystal water, supposed to be endowed with miraculous properties. The whole hill is moreover pierced with galleries and store-chambers, and served as a refuge in time of war, in which the villagers of Lavardin concealed their goods. The noble rum of the castle shows that it was once of great majesty. It was battered down by the Huguenots, who for the purpose dragged a cannon to the top of the church tower.

Nearer to Vendôme is the Château of Rochambeau. The present mansion that has replaced the ancient castle is a 


\section{MODERN TROGLODYTES}

very insignificant and tasteless structure. All the interest it possesses consists in its dependencies that are rock-hewn. The bass-court is reached through a long and lofty gallery bored athwart the rock, and issuing from it we find ourselves in a sort of open well, probably originally natural but appropriated and adapted by man to his needs. This vast depression, the walls of which are seventy-five feet high, is circular, and measures eighty feet in diameter. Round it are cellars and chambers for domestic purposes. Others are accessible from the gallery that leads to the court. One of them, the Cave-Noire, possesses a chimney bored upwards through the rock to the level of the surface. Another peculiarity of this cavern is that along one side, throughout its length, 120 feet, are rings cut in the rock showing tokens of having been fretted by usage. 'They are at the height of four feet above the soil, and are on an average four feet ten inches apart. A second range is three feet or four feet higher up. In an adjoining cavern are similar ranges of rings. A third is cut almost at the level of the soil. Precisely the same arrangement is to be found at Varennes hard by in artificial caves still employed as stables, and some as dwellings for families.

In the park is shown the cave in which the Duke of Beaufort, the Roi des Halles, was concealed when he escaped from the prison of Vincennes. François de Vendôme, Duke of Beaufort, was a grandson of Henri Quatre, a man of inordinate conceit and of very limited intelligence. During the regency that began in 1643 , he obtained the confidence of Anne of Austria, but his vanity rendered him insupportable, and he went out of his way to insult the regent, so that she sent him to Vincennes. Voltaire passes a severe judgment on him. He says of the Duke: "He was the idol of the people, and the instrument employed by able men for stirring them up into revolt; he was the object of the raillery of the Court, and of the Fronde as well. He was 38 


\section{MODERN TROGLODYTES}

always spoken of as the Roi des Halles, the Market-King." One day he asked the President Bellevue whether he did not think that he-Beaufort-would change the face of affairs if he boxed the ears of the Duke of Elbeuf. "I do not think such an act would change anything but the face of the Duke of Elbeuf," gravely replied the magistrate.

There are in the Quartier S. Lubin at Vendôme chambers still occupied in the face of the cliff, high up and reached by structural galleries.

At Lisle, on the river above Vendôme, are many caves, one of which was the hospital or Maladerie.

Above 'Tours and Marmoutier, on the road to Vouvray, is La Roche Corbon. The cliff is pierced with windows and doors, and niches for a pigeonry. This, till comparatively recently, was a truly Troglodyte village. But well-to-do inhabitants of 'lours have taken a fancy to the site and have reared pretentious villas that mask the face of the cliff, and with the advent of these rich people the humble cavedwellers have "flitted." One singular feature remains, however, unspoiled. A mass of the cretaceous tufa has slipped bodily down to the foot of the crag, against which it leans in an inclined position. 'This was eviscerated and converted into two cottages, but the cottagers have been ejected, and it is now a villa residence. An acquaintance at Tours has rented it for his family as a summer seat.

Some fifty or sixty years ago La Roche Corbon was "a village sculptured up the broken face of the rocks, with considerable skill, and what with creeping vines, snatches of hanging gardens, an attempt here and there at a division of tenements, by way of slight partitions cut from the surface, wreaths of blue smoke issuing out of apertures and curling up the front, and the old feudal tower, called Lanterne de la Roche Corbon, crowning the summit, the superincumbent pinnacle of excavated rock on which it stands looking sa if it were ready to fall and crush the whole population 39 


\section{MODERN TROGLODY'TES}

beneath, this lithographed village has altogether a curiously picturesque look." But at Beaumont-la-Ronce, north of Tours, may be seen a whole street of cave habitations still occupied, wreathed with vines and traveller's joy.

In the department of Mainc et Loire, and in a portion of Vienne, whole villages arc underground.

There is often very valuable vineyard land that has to be walled round and every portion economised. What is done is this: the owner digs a quarry in the surface; this forms a sort of pit accessible on one side, the stone taken from this being employed to fence round his property. 'Then, for his own dwelling, he cuts out chambers in the rock under his vineyard, looking through windows and a door into the quarry hole. For a chimncy he bores upwards, and then builds round the opening a square block of masonry, out of which the smoke escapes.

A whole village, or rather hamlet, may therefore consist of -as far as one can see-nothing but a series of chimneys standing on the ground among the vines. Those who desire to discover the inhabitants must descend into the quarries to these rabbit warrens.

In some villages the people live half above ground and half below. At St. Leger, near Loudun, is a fine mediæval castle, with a fosse round it cut out of the rock; and this fosse is alive with people who have grubbed out houses for themselves in the rock through which the moat (which is dry) has been excavated.

A very singular settlement is that of Ezy in the valley of the Eure, at the extreme limit of the department of that name. About a kilometre from the village, along the side of the railway, are numerous subterranean habitations in three storcys, with platforms before them which are horizontal. These were the dwellings of the owners of the vines which at one time covered the hill orerhead. But these vineyards failed, and the dwellings werc abandoned. However, after 


\section{MODERN TROGLODYTES}

their abandonment, it was customary at times for the villagers to resort to them for drinking and dancing bouts. 'Ihis tradition continues still in force, and on Easter 'I'uesday these cave dwellings are visited, and there is merrymaking in them. Between the cares at one time some little taverns had been erected, but these also fell into ruin some forty or fifty years ago.

Since then a range of these caverns has become the refuge of a special population of social and moral outcasts. There they live in the utmost misery. 'The population consists of about eighty persons, male and female and children.

The history of the adults will hardly bear looking into. None of these people have any fixed occupation, and it is difficult to discover how they subsist. In fact, the life of every one of them is a problem. One might have supposed that they maintained a precarious existence by thieving or by begging, as they are far below the ordinary tramp; for with the exception of perhaps two or three of them, these cave-dwellers possess absolutely nothing, and know no trade whatever. They sleep on dry leaves kept together by four pieces of wood, and their sole covering consists of scraps of packing cloth. Sometimes they have not even the framework for their beds, which they manufacture for the most part out of old broken chairs discarded from the churches. A visitor says: "In one of the caverns I entered there was but one of these squalid and rude beds to accommodate five persons, of whom one was a girl of seventeen, and two were boys of fourteen and fifteen. Their kitchen battery consists exclusively of old metal cases of preserved fruit or meats that they have picked up from the ashpits. The majority, but by no means all, have got hold, somehow, of some old stoves or the scraps of a stove that they have put together as best they could. They have a well in common at the bottom of the hill, whence they draw water in such utensils as they possess, and which they let down into the water on a wooden 


\section{MODERN TROGLODYTES}

crook. Every one has his crook as his own property, and preserves it near him in the cavern. The majority of these underground people have no clothes to speak of. Girls of fifteen and big boys go about absolutely without any linen. The rest-perhaps three or four-have only a few linen rags upon them. In the stifling atmosphere of these cave-dwellings it is by no means rare to see big children almost, if not absolutely, naked. I saw a great girl with a wild shock of uncombed hair, wearing nothing but a very scanty shift.

"These cave-dwellers live with utter improvidence, although deprived of sufficient food. Three or four couples there have some four or five children to each.

"These families have for the most part formed in the cave-dwellings. A young mother whom I saw there with four children, the only one dressed with an approach to decency, when interrogated by me told me that she had been brought there by her mother at the age of eight. That was tiventy-four years ago. She was fair, with tawny hair, and of the Normandy type. She had been born in a village of the neighbourhood, and her mother took refuge in the caverns, apparently in consequence of the loss of her husband.

"I heard of an individual who had been on the parish on account of his incurable laziness, till the mayor losing all patience with him, had him transported to these cavedwellings and left there. There he settled down, picked up a wife, and had a family.

"These people live quite outside the law, and are quit of all taxes and obligations. As to their marriages they are preceded and followed by no formalities. No attempt is made on the part of the authorities to get the children to school. One gentleman resident in the neighbourhood, a M. Frederic Passy, did take pains to ameliorate their condition. He collected the children and laboured to infuse 


\section{MODERN TROGLODYTES}

into their hearts and heads some sort of moral principle. But his efforts were ineffectual, and left not a trace behind. They recollect him and his son well enough, but confuse the one with the other. And two of those who were under instruction for a while, when I questioned them about it, allowed that they had submitted to be bored by them for the sake of profiting by their charity.

"I interrogated an old but still robust woman, who had lived in the caverns for three years. She had been consigned to them by her own children, who had sought by this means to rid themselves of the responsibility of maintaining her.

"The elements of this population belong accordingly to all sorts. I noticed only one woman of an olive tint and with very black hair, who may have come from a distance. But I was told she was a recent accession to the colony, and I might be sure of this, as her clothing was still fairly sound and clean. As she is still young and can work, her case is curious; one wonders what can have induced her to go there.

"I saw there also a couple without children; the man had the slouch and hang-dog look of an habitual criminal.

"I may give an instance which will show the degradation to which this population has fallen. An old beggar I visited, who has lived in a cavern belonging to his brother for forty-seren years, and who has had a wife, allowed a billiard ball to be rammed into his mouth for two sous (a penny) by some young fellows who were making sport of him. He was nearly killed by it, for they had the greatest difficulty in extracting the billiard ball." 1

At Duclair also, on the Seine, are rock dwellings precisely like those on the Loire, and still inhabited.

Along the banks of the Loire from Tours to Saumur are numerous care habitations still in occupation. Bell, in his

1 Zaborowski, "Aux Cares d'Ez5," in Revue Monsulle de lécole d'Anthropologie, Paris, 1897, i. p. 2T, et seq. 


\section{MODERN 'TROGLODY'TES}

"Wayside Pictures," says of those at Saumul: "Close to the town are residences, literally sculptured in the face of the naked rock. They are cut in the stone, which is the tufa, or soft gravel stone, and easily admits of any workmanship demanded by taste or necessity. There is no little care displayed in the formation of these strange habitations, some of which have scraps of gardens or miniature terraces before them; hanging from the doorways are green creeping things, with other graceful adjuncts, which help to give a touch of beauty to their aspect. In some cases, where the shelving of the rock will admit of it, there are chimneys, in nearly all windows; and it not unfrequently happens, especially higher up the road near 'Tours, where art has condescended to embellish the façades still more elaborately, that these house-caves present an appearance of elegance which is almost impossible to reconcile with the absolute penury of their inhabitants. 'The interiors, too, although generally speaking naked enough, are sometimes tolerably well furnished, having an air of comfort in them which, certainly, no one could dream of discovering in such places.

"'These habitations are, of course, held only by the poor and outcast, yet, in spite of circumstances, they live merrily from hand to mouth how they can, and by means, perhaps, not always of the most legitimate description. I have a strong suspicion that the denizens of these rocks are not a whit better than they should be ; that their intimate neighbourhood is not the safest promenade after dark: and that, being regarded and treated as Pariahs, they are born and baptized in the resentments which are contingent upon such a condition of existence. You might as well attempt to chase an eagle to his eyrie among the clouds, as to make your way to some of these perilous chambers, which are cut in the blank face of the rock, and can be reached only by a sinuous track which requires the fibres of a goat to clamber. There are often long lines of these sculptured houses piled in 


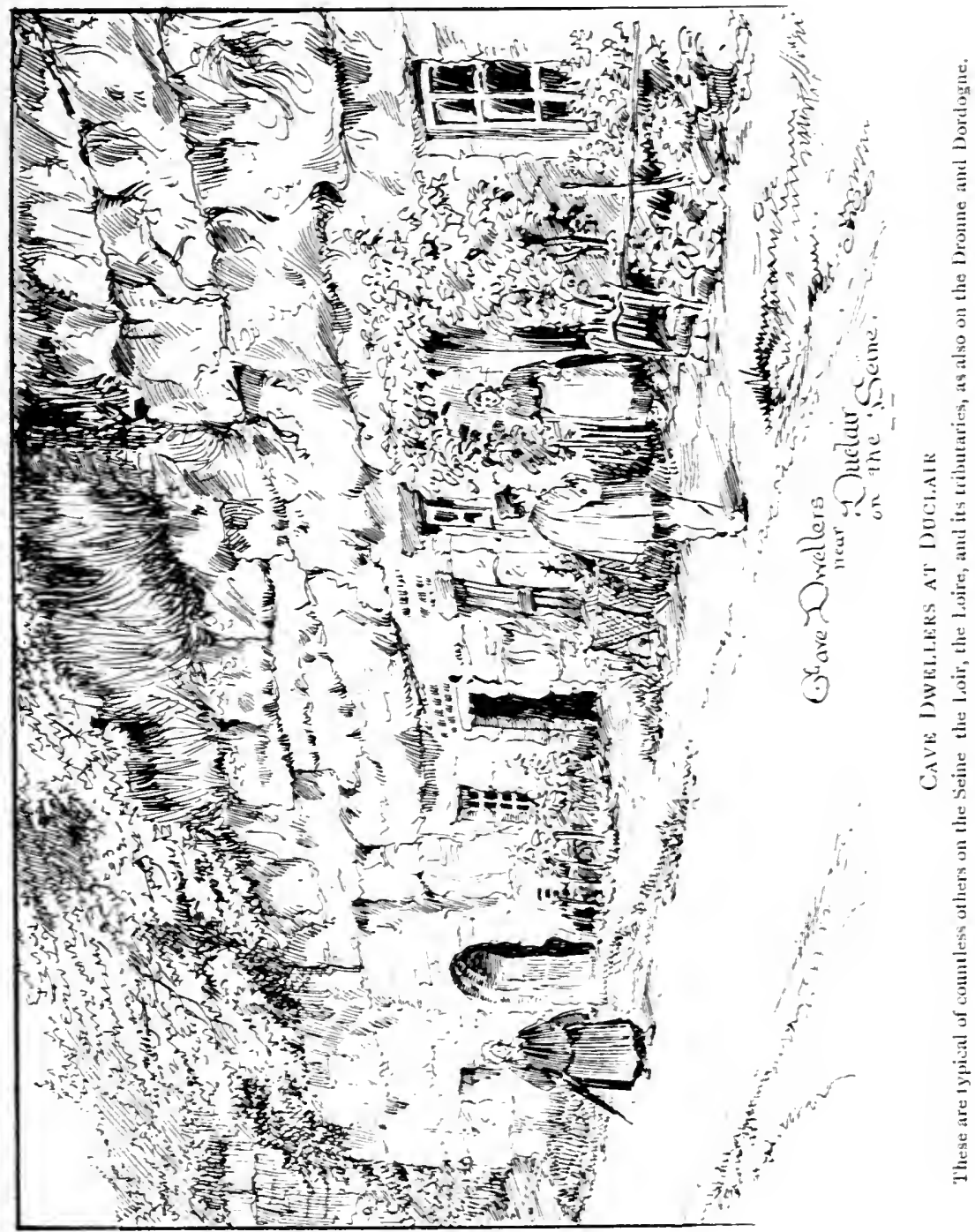





\section{MODERN 'TROGLODY'TES}

successive tiers above each other; sometimes with a view to architectural regularity, but in almost all cases they are equally hazardous to the unpractised foot of a stranger.

"Stroll down the spacious quay of Saumur in the dusk of the evening, when the flickering tapers of the temperate town are going out one by one. Roars of merriment greet you as you approach the cavernous city of the suburb. There the entertainments of the inhabitants are only about to begin. You see moving lights in the distance twinkling along the grey surface of the rock, and flitting amongst the trees that lie between its base and the margin of the river. Some bacchanalian orgie is going forward." 1

There was a curious statement made in a work by $\mathrm{E}$. Bosc and L. Bonnemère in 1882,2 reproduced by M. Louis Bousrez in $1894,{ }^{3}$ which, if true, would show that a lingering paganism is to be found among these people. It is to this effect: "What is unknown to most is that at the present day there exist adepts of the worship (of the Celts) as practised before the Roman invasion, with the sole exception of human sacrifices, which they have been forcibly obliged to renounce. They are to be found on the two banks of the Loire, on the confines of the departments of Allier and Saone-et-Loire, where they are still tolerably numerous, especially in the latter department. They are designated in the country as Les Blancs, because that in their ceremonies they cover their heads with a white hood, and their priests are vested like the Druids in a long robe of the same colour.

"They surround their proceedings with profound mystery ; their gatherings take place at night in the heart of large forests, about an old oak, and as they are dispersed through the country over a great extent of land, they have to start

1 Bell (R.), " Wayside Pictures," Lond. 1850, pp. 292-3.

2 Hist. des Gaulois sous Fercingetorix. Paris, 1882.

3 Les monuments Mégalithiques de la Touraine. Tours, 1894. 


\section{MODERN 'TROGLODY'TES}

for the assembly from different points at close of day so as to be able to reach home again before daybreak. 'They have four meetings in the year, but one, the most solemn, is held near the town of La Clayette under the presidence of the high priest. Those who come from the greatest distance do not reach their homes till the second night, and their absence during the intervening day alone reveals to the neighbours that they have attended an assembly of the Whites. 'Their priests are known, and are vulgarly designated as the bishops or archbishops of the Whites; they are actually druids and archdruids. ... We have been able to verify these interesting facts brought to our notice by $M$. Parent, and our personal investigations into the matter enable us to affirm the exactitude of what has been advanced."

If there be any truth in this strange story, we are much more disposed to consider the Whites as relics of a Manichæan or Albigensian sect than as a survival of Druidism. More probable still is it that they are or were a political confederation. But I suspect that the account is due to a heated imagination.

At Bourré (Loir et Cher) are extensive quarries in the face of the hill. Here the chalk is hard and of beautiful texture. The stone has been derived hence for the erection of several of the castles in the Touraine, as also for buildings in the towns of 'Yours, Blois, Montrichard, \&c. Most of the habitations of the villagers, who are nearly all quarrymen, are excavated in the rock, occupy old disused workings, or have been specially dug out to suit the convenience and dispositions of the occupants. In some of these old underground quarries, that are not open to the light of day, dances and revelries take place, when they are brilliantly illuminated. At Sainte Maure, on the road from Tours to Chatelherault, in a deep cleft of the Cande that is covered with the falun, an extensive deposit of marine and freshwater 46 


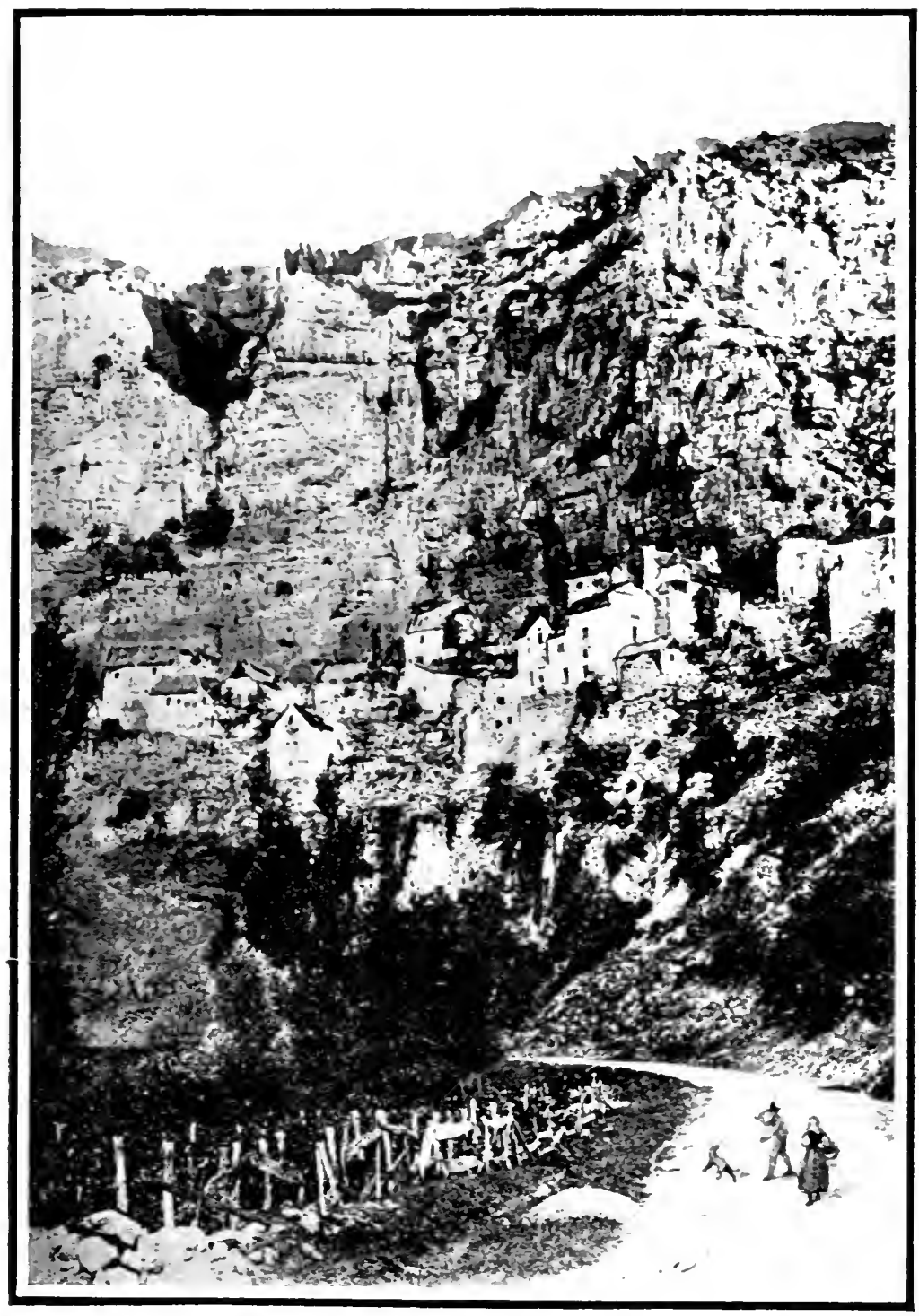

SACLIAC

A village in the valley of the Cèlé, Lot, built partly into the ro:ks, with chambers excavated out of the cliff. 



\section{MODERN TROGLODY'TES}

shells, marking the beach of an old estuary of the sea, is the village of Courtineau, wholly made up of Troglodyte habitations, and with its chapel also excavated in the rock.

At Villaines (Indre et Loire) the cliffs are pierced with cares that are inhabited by basket-makers, and the watercourses below are planted with willow, or else have cut osiers lying in them soaking to preserve their suppleness. In the caves, on the roads, in every house, one sees little else but baskets in process of making or cut osiers lying handy for use. The women split and peel the green rods, men and children with nimble fingers plait the white canes. All the basket-makers are themselves plaited into one co-operative association. From time inmemorial Villaines had made baskets, the osier of the valley being of excellent quality. But the products could not be disposed of satisfactorily; they were bought by regraders, who beat down the prices of the wares, and the workmen had no means of seeking out the markets, in which to sell with full advantage to themselves. In 1845 an old curé, whose name is remembered with affection, the Abbé Chicogne, conceived the idea of creating a co-operative society; and aided by the Count de Villemois, he grouped the workers, and drew up the statutes of the Association, that remain in force to the present day. All the products are brought together into a common store, and sold for the benefit of the associates. No member is permitted to dispose of a single piece of his workmanship to a purchaser; he may not sell in gross any more than he may in detail. The cave-houses are comfortably and neatly furnished, and their appearance and that of their inhabitants proclaims well-being, content and cheerfulness.

On the Beune, a tributary of the Vézère, is the hamlet of Grioteaux, planted on a terrace in a cave, the rock overhangs the houses. Above the cluster, inaccessible without a ladder, in the face of the cliff, is a chamber hewn out of the rock, and joist holes proclaiming that at one time a $4 \gamma$ 


\section{MODERN 'TROGLODY'TES}

wooden gallery preceded it. 'This cavern, that is wholly artificial, served in times of trouble as a place in which the community concealed their valuables.

The river Célé that flows into the Lot passes under noble cliffs of fawn and orange-tinted limestone, and the road here is called Le Défilé des Anglais, as the whole valley during the Hundred Years' War was in the possession of the Companies that pretended to fight for the Leopards. And it was down this defile that the cutthroats rode on their plundering expeditions. In this valley is the village of Sauliac, in an amphitheatre of rocks, where road and river describe a semicircle. The cliff runs up to a height of 300 feet. Houses are perched on every available ledge, grappling the rock, where not simply consisting of faced caverns. In the midst of this cirque stands the castle, buried in stately oaks. It was not built till 1460, when the long agony of the war was over, and nothing remained of the English save their empty nests in the rock, and their hated name.

A modern chapel, very white and not congruous with its surroundings, is perched above the road on a terrace under Le Roc Percé, so named from a natural cavern, very round, drilled through it, as though wrought by a giant's boring tool.

At Cuzorn, on the line from Perigueux to Agen, are very fine rocks in a meander of the Lemance, starting out of woods, and these contain caverns that have been, and some still are, inhabited. In this region are many quarries, not open to the sky, but forming halls and galleries under the hill, and some of these have been taken possession of and turned into habitations.

At Brantône on the Dronme a good many of the houses are against the rock, the caves built up in front with the usual window and door to each. More have their workshops in grottoes, in them blacksmiths have their forges, carpenters their planing benches, tinkers, tailors, cobblers 

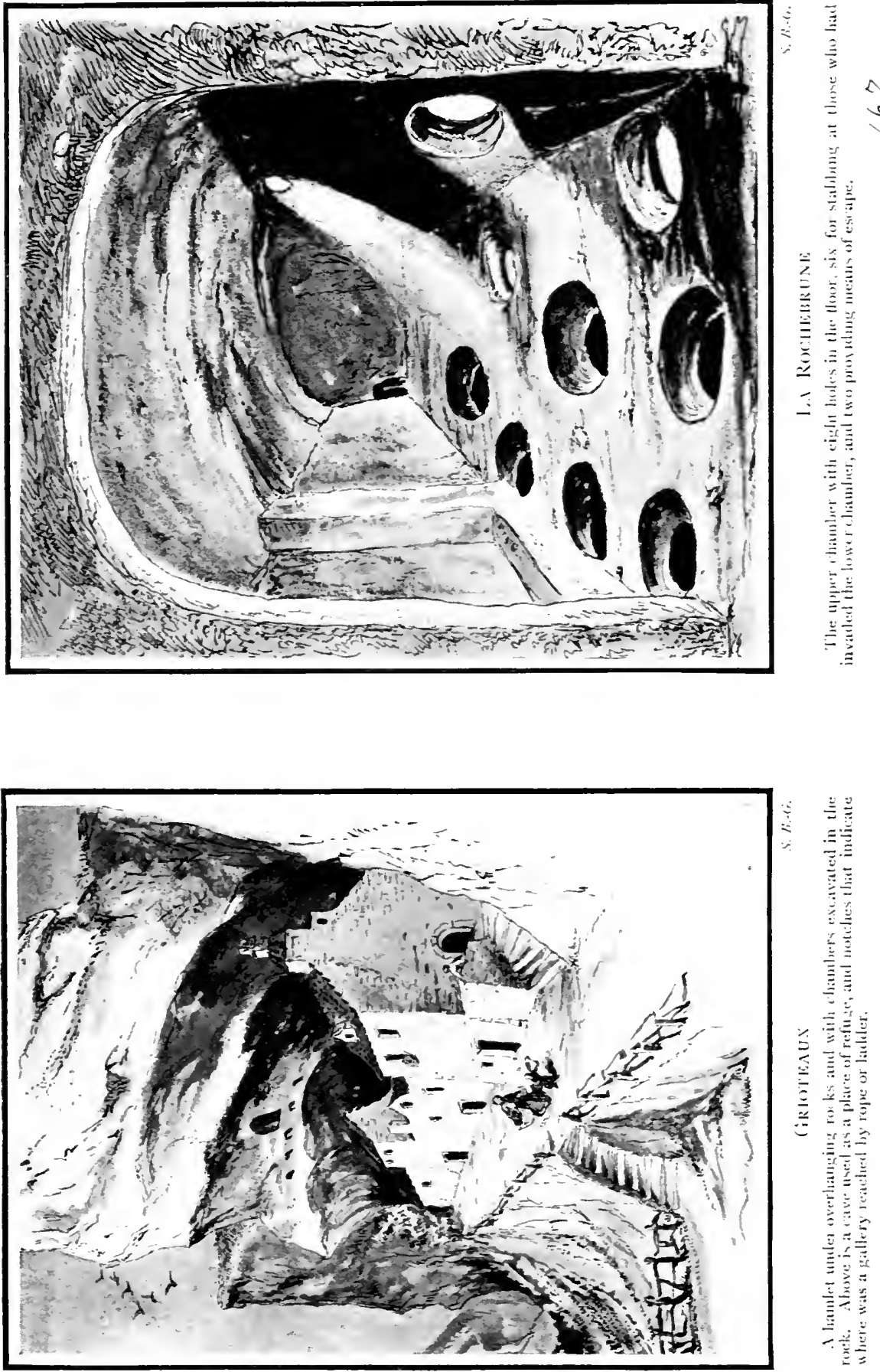

0
0 


$$
\text { . }
$$




\section{MODERN 'TROGLODYTES}

carry on their business in comparative obscurity. The superior stratum of rock is of so hard and tenacious a quality that it holds together with very few piers to support it. When a citizen wants to enlarge his premises, he merely digs deeper into the hill; he has no ground-rent to pay. Some caves open a hundred feet wide without a support.

Any one motoring or going by rail from Angoulême to Périgueux should halt half-way at La Roche Beaucourt, where the rock l'Argentine contains a nest of cave-dwellings, with silos in the floors and cupboards in the walls.

That the savage is not extinct in these out-of-the-way parts may be judged from this-that at Hautefaye near by, the peasants in $18 \% 0$ laid hold of M. de Moneis, who objected to the prosecution of the war with the Prussians after Sedan, cruelly maltreated him, and threw him alive on a bonfire in which he expired among the flames.

The whole south-east angle of the Isle of Sicily is full of underground cities, of which that of the Val d'Ispica is the most famous. These excavations are vulgarly called Ddieri, but they are not in most cases tombs, but dwellingplaces for the living, as is shown by the handnills for oil and corn that are found in them.

The Val d'Ispica is a narrow valley situated between Modica and Spaicaforno; and throughout its entire length of about eight miles, the rock walls are pierced on both sides with countless grottoes, all artificial, and showing the marks of tools on their walls. They are scooped in the calcareous rock. Some consist of as many as ten or twelve chambers in succession, and are seldom more than 20 feet deep by 6 feet high, and they are of the same breadth. At the bottom of the valley flows a little stream that supplied the inhabitants with water, and irrigates wild figtrees and pink-flowered oleanders. On a higher level grow broad-leaved acanthi and wild artichokes, and thick festoons of cactus hang down from the top of the rock and 49 


\section{MODERN TROGLODYTES}

shade the entrances to the grottoes. A portion of the rock wall on the right bank of the stream has fallen, and exposed to sight the internal arrangement of the dwellings. But previous to this, ascent could only have been made by ladders or by notches in the rock for the insertion of toes and fingers, as among the cliff-dwellers in Arizona. There are ranges of these habitations on several stages, and steps cut in the rock allowed communication between them; but above all is a ledge or gallery open to the sky and commanding a magnificent prospect. This could be reached only by a ladder, and probably formed the rendezvous of the women of the Troglodyte town in an evening to enjoy the cool air, and exercise their tongues. It may also have served as the last refuge of the inmates of the caverns, who, after escaping to it could withdraw the ladder.

One dwelling of three storeys, with flights of steps in good preservation, is called the Castle by the peasants. Parthey, a German traveller, who investigated these dwellings, reckoned their number to be over 1500. He saw nowhere any trace of ornament about them. Doors and windows were mere rough holes cut through the limestone. Rings hewn in the stone which are found in the chambers probably served some purpose of domestic economy. Fragments of Samian ware and carved marble have been found in them, but are probably later than the construction of these habitations. Some contain graves, and these also may be later, but actually we know from history nothing about them. Rock tombs may have been utilised as dwellings or abandoned dwellings as tombs. To the present day some of them are still occupied, mainly by shepherds and poor peasants. The range in the Crimea from Cape Kersonese to the Bay of Ratla is formed of layers of limestone alternating with clay and argilaceous schist, a disposition of the strata that tends greatly to accelerate the disintegration of the cliffs. The clay gradually washed out 50 


\section{MODERN TROGLODY'IES}

by springs or eaten away by the weather forms great caverns in the sides, and these are liable to fall in when deprived of support. They have, however, been utilised as habitations. The Rock of Inkermann, the ancient Celamita, runs east of the town beyond the marshy valley of the Chernaya; it has been converted into a vast quarry which meriaces with destruction the old Troglodyte town that occupied the cliffs. The galleries of this underground town form a rabbit warren in which it is dangerous to penetrate without a. guide or a clue. Some of the chambers are large enough to contain five hundred people.

The rocks of Djonfont-kaleharri are also honeycombed, with still inhabited caves; some are completely cavernous, but others have the openings walled up so as to form a screen. Beneath an overhanging rock is a domed church used by this Troglodyte community.

If we cross the Mediterranean to Egypt, we see there whole villages of cave-dwellers. The district between Mansa-Sura and Cyrene is full of grottoes in the very heart of the mountains, into which whole families get by means of ropes, and many are born, live and die in these dens, without ever going out of them.

The volcanic breccia as well as chalk and limestone has been utilised for the habitation of man. There is a very interesting collection of cave-dwellings all artificial, the Balmes du Montbrun, a volcanic crater of the Coiron, near S. Jean le Centenier in the Vivarais. The crater is 300 feet in diameter and 480 feet deep; and man has burrowed into the sides of porous lava or pumice to form a series of habitations, a chapel, and one that is traditionally said to have served as a prison. This rock settlement was occupied till the close of the eighteenth century.

The Grottoes de Boissière are twelve in number, on the side of the Puy de Châteauneuf, commanding the road from Saint Nectaire to Marols, Puy de Dôme. They are 


\section{MODERN 'TROGLODYTES}

excavated in the volcanic tufa, and are all much of the same dimensions; one, however, measures 28 feet by 12 feet, and is 7 feet high. Below the grottoes the slope of the hill is parcelled out into small fields or gardens by means of walls of stones laid one on another without mortar, showing that the inhabitants of these caves lived there permanently and cultivated the ground below their dwellings. ${ }^{1}$ More curious still are the Grottoes de Jonas on the Couze, also in Puy de Dôme, near Cheix. They are in stages one range above another to the height of from 90 to 120 feet. The face of the mountain is precipitous, and is of a porous tufa full of holes. As many as sixty of these artificial caves remain; but there were at one time many more, that have been destroyed by the fall of the very friable volcanic rock. It is impossible to determine the period at which these caves were excavated; they were probably prehistoric to begin with, but were tenanted during the Middle Ages when-if not later-the tracks leading to them were cut in the tufa and stairs to connect the several stages. Then paths were bordered by walls as a protection, and fragments of the parapet remain. Probably it was during the English occupation of Guienne which extended into Auvergne, that a castle and a chapel were sculptured out of the living rock. At the same time a remarkable spiral staircase was contrived in like manner. Numerous relics of all periods-flint tools, bronze weapons, statuettes, and coins-have been found among the rubbish thrown out from these dens. ${ }^{2}$

On the Borne, in Haute Loire, dug out of the volcanic rock are several cave-dwellings. The cares at Conteaux are fourteen in number, the largest is divided into three com-

1 There are others, Les Grottes de Rajah, in the same mass of rock, with near them an isolated rock carved about and supposed to have been an idol.

2 G. Tournier, Les Mégalithes et les Grottes des environs de S. Nectaire. Paris, 1910. 


\section{MODERN TROGLODY'TES}

partments; each is $\mathbf{4 5}$ feet deep and 11 feet wide, but the usual dimension is from 28 to 36 feet. In all, the vault is rather over 6 feet high. An opening in the roof of one gave vent to smoke.

The rock of Ceyssac is curious. Formerly a barrier of volcanic tufa stretched across the valley of the Borne; this barrier had been ejected from the volcano of La Denise. 'The river, arrested in its onward course, was ponded back and formed a lake that overflowed the dam in two places, leaving between them a fang of harder rock. When the water had spilled for a considerable time over the left-hand lip, and had worn this down to a depth of about 70 feet, it all at once abandoned this mode of outlet and concentrated its efforts on the right-hand portion of the dam where it found the tufa less compact. It eventually sawed its way completely through till it reached its present level, leaving the prong of rock in the middle rising precipitously out of the valley with the river gliding peacefully below it, but attached to the mountain side by the neck it had abandoned. The fang was laid hold of, burrowed into, and converted into a village of Troglodytes. In it are cave-dwellings in five superposed storeys, stables with their mangers, with rings for tying up cattle, a vast hall, that is circular, and chambers with lockers and seats graven out of the sides of the walls. There is also a subterranean chapel, with the entrance blocked by a wall that contains an early Romanesque doorway. 'The Polignacs seized on the spike of rock and built on the summit a castle that could be reached only by a flight of steps cut in the face of the rock. By degrees the inhabitants have migrated from their caves to the neck of land connecting the prong with the hill, and have built themselves houses thereon. 'They have even abandoned their monolithic church and erected in its place an unsightly modern building.

There are other care-dwellings in the rolcanic rocks of 53 


\section{MODERN TROGLODYTES}

the Cevennes and Auvergne, but the above account must suffice.

I will now say something about the Troglodyte dwellings in the sandstone in Corrèze, in the neighbourhood of Brive, caves that have been inhabited from the time of the man who was contemporary with the mammoth, to this day. Some have, however, been abandoned comparatively recently.

They do not run deep into the rock; usually they face the south or south-west, and are sometimes in a series at the same level; sometimes they form several storeys, which communicated with each other by ladders that passed through holes cut in the floor of the upper storey, or else by a narrow cornice, wide enough for one to walk on. Sometimes this cornice has been abraded by the weather, and fallen away; in which case these cave-dwellings can be reached only by a ladder. There are caves in which notches cut in the rock show where beams had been inserted, and struts to maintain them, so as to form a wooden balcony for communication between the chambers, or between the dwellings of neighbours.

The doorways into these habitations are usually cut so as to admit a wooden frame to which a door might be attached; and there are deep holes bored in the rock, very much as in our old churches and towers, for the cross-piece of timber that effectually fastened the door.

The grottoes are cut square, the ceilings are always sensibly horizontal, and the walls always vertical. But where a natural hollow has been artificially deepened, there the opening is usually irregular. Moreover, in such case, the gaping mouth of the cave was in part walled up. The traces of the tool employed are everywhere observable, they indicate that the rock was cut by a pick having a triangular point. Small square holes in the sides, and long horizontal grooves indicate the position of shelves. Square hollows of considerable size served as cupboards, and oblong rectangular 


\section{MODERN TROGLODYTES}

recesses, 18 inches above the floor, and from 3 feet 9 inches to 4 feet 6 inches high and a foot deep were benches. Bedplaces were also cut in the rock.

There are also indications of a floor having been carried across in some of the loftier caves, and there are openings in the roofs through which ascent was made to the series of chambers on the upper storey. Holes pierced in the ceiling served for the suspension of articles liable to be

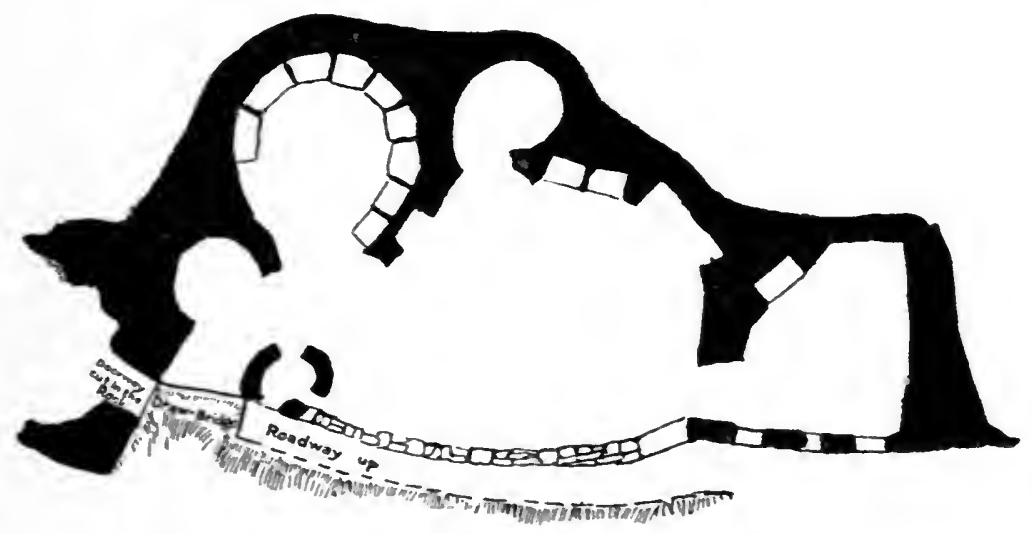

Sketch Plan of Rock Stable, Commarques.

injured by proximity to a damp rock. A string was attached to the middle of a short stick, that was thrust into the hole. The string was then pulled and it was fast. Another plan was that of boring holes at an angle into the rock at the side. Into these holes rods were thrust and what was required to be kept dry was suspended from them.

Some of the grottoes served at once for man and beast and fowl. Not only are there chambers for the former, but also mangers for cattle, and silos to contain the fodder; and there are nooks for pigeons in an adjoining cave. In many cases there are cisterns ; in one is a well. The cisterns had to be filled laboriously. They are provided with bung55 


\section{MODERN 'IROGLODY'IES}

holes for the purpose of occasional cleaning out. The walls are scored with concave grooves slanting downwards, uniting and leading into small basins. The moisture condensing on the sides trickled into these runnels and supplied the basins with drinking water. The mangers have holes bored in the stone through which passed the halters. There are indications that the cattle were hauled up by means of a windlass.

That these were not places of refuge in times of danger, but were permanent habitations, would appear from the fact that those of Lamouroux contain mural paintings, and that in them, in addition to stables, there is a pigeonry. In one or two instances the piers that support the roof have sculptured capitals, of the twelfth or thirteenth century. In the cave-dwelling still tenanted at Siourat is cut the date, I.D. 1585, surmounted by a cross. ${ }^{1}$

I have given the plan of the caves of Lamouroux in my "Deserts of Southern France."

How general rock habitations were at one time in Perigord may be judged by the prevalence of the place-name Cluseau, which always meant a cave that was dwelt in, with the opening walled up, window and door inserted; roffi is applied to any ordinary grotto, whether inhabited or not.

It would be quite impossible for me to give a list of the cave-dwellings in France still inhabited, or occupied till comparatively recent times, they are so numerous and are to be found in every department where is the chalk or the limestone, sandstone or volcanic tufa.

They are to be met with not only in those parts of France from which the above specimens have been taken and described, but also in Var, Bouches du Rhone, Aveyron, Gard, Lozère, Cantal, Charente, Vienne, \&c.

There is a good deal of sameness in the appearance of

1 Lalande (Ph.), Les Grottes artificiclles des environs de Brive. In Mímoircs de la Soc. de Spélioloyic. Paris, 1897. 


\section{MODERN TROGLODY'TES}

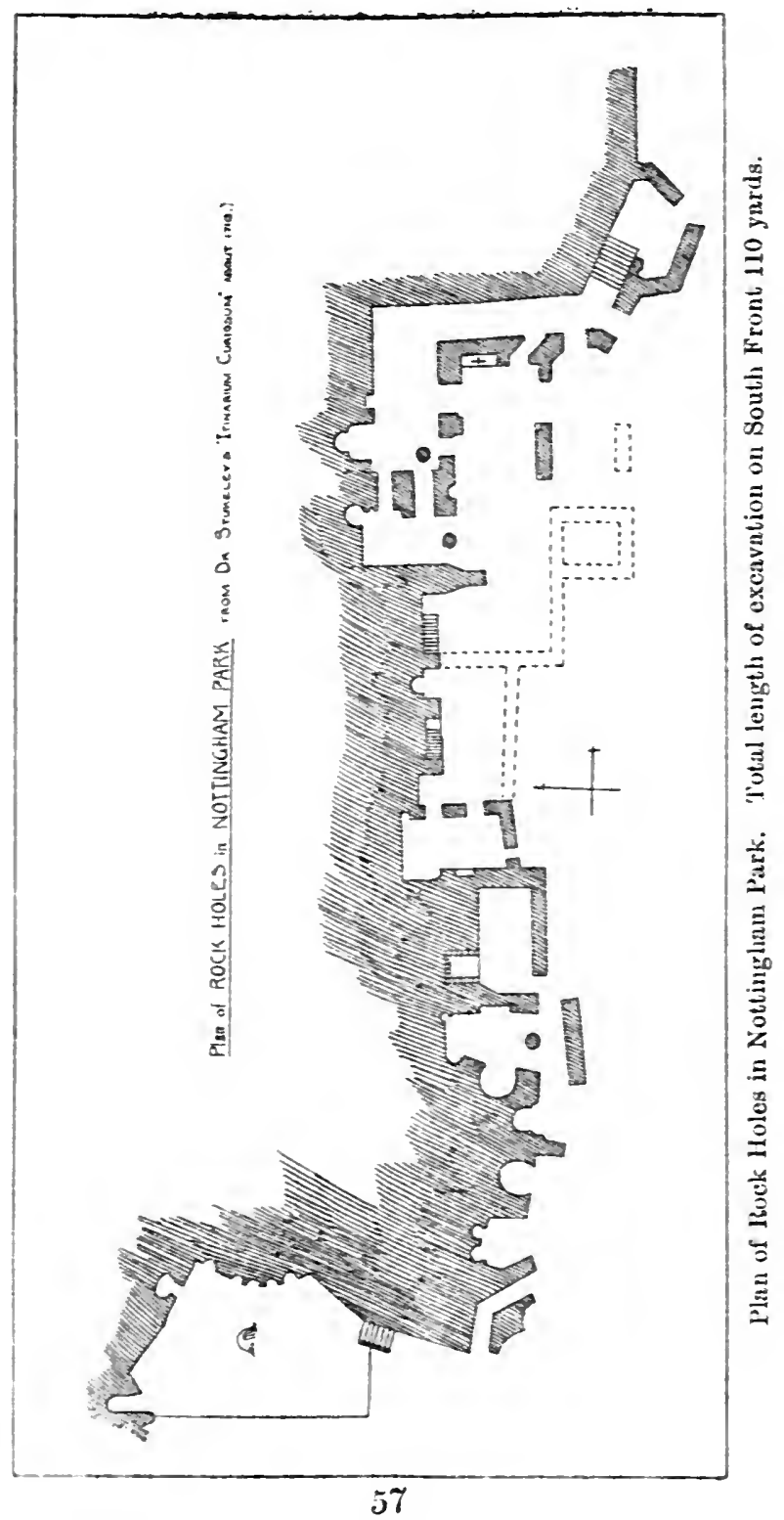




\section{MODERN TROGLODYTES}

those still inhabited - a walled face, a mask, with window and door, and above a chimney of brick rising out of the rock.

In England, Nottingham drew its ancient British name of Tigguocobauc (House of Caves) from its troglodyte habitations; at Mansfield in that county such caves exist, and were associated with a class of inhabitants somewhat nomadic, who obtained their living by making besoms from the heather of the adjoining forest and moorland. They established a colony on the roadside waste, and sank wells in the rock for water. Nottingham enjoyed possibly the largest brewing and malting business in the country, and those trades were nearly wholly carried on in chambers and cellars and kilns cut out of the living rock. Mr. W. Stevenson, author of "Bygone Nottinghamshire," writes to me: "Last week I was with an antiquarian friend exploring an ancient passage in the castle rock, originally made as a sallyport to the castle, but at some later period when bricks came on the scene, converted or enlarged into a set of malt offices with malt kilns complete. Their original use and locality have been lost for a century, and their recovery is just being brought about. 'Their situation, high over the adjoining meadow, and their presence in the very heart of the rock that rises abrupt to the height of $\mathbf{1 3 3}$ feet is truly romantic. The foot of the range of cliffs, with a south aspect, was a favoured site. Here we find communities of monks dwelling for centuries, hermits spotted about, and a great part of the town-dwellers, tanners, dyers, and other trades where water was largely required. A peculiarity of these houses was their fresh-water supply. The denizens sank holes in their living apartments with steps cut in the rock until they got down to the water level, where they had little pools of fresh water. The system was known as Scoop-wells, and must have been very ancient. Those who lived on higher levels burrowed into the sides of sunken roads, and the track-lines 


\section{MODERN TROGLODYTES}

of ancient military defences. In deeds of transfer of property it was customary to describe tenements as below or above ground. Old writers have said that they doubted if the erections above ground would fill the space excavated below ground; and to-day, when erecting new buildings, it is necessary to drill down into the rock a yard or more to ascertain that the foundations are not to be laid above the crowns of hidden vaults, chapels, or unknown habitations."

'Thoroton, in his history of Nottinghamshire, 1797, gives an illustration of rock-dwellings at Sneynton, adjoining Nottingham, but they have recently been cleared away for railway extension.

The sanitary authorities have done their best to sweep the tenants out of the Nottingham cave habitations, but in Staffordshire at Kinver there are still troglodytes.

Holy Austin's Rock is a mass of red sandstone, a spur of the bluff of Kinver Edge, that is crowned by the earthworks of what is supposed to have been a camp of Penda. But it has been broken through by wind and rain and perhaps sea, and now stands out unattached. It is honeycombed with habitations. I have been into several. They are neat and dry, and the occupants are loud in praise of them, as warm in winter and cool in summer. They are in two stages. At Drakelow also there are several, also occupied, somewhat disfigured by hideous chimneys recently erected in yellow and red bricks. One chimney is peculiarly quaint as being twisted, like a writhing worm, to accommodate itself to the shape of the overhanging rock. Another series of these habitations is now abandoned, but was occupied till a comparatively recent period, and other houses have their stables and storerooms excavated out of the rock.

Although Derbyshire abounds with caverns, some natural, some the work of miners, from Roman times, they do not appear to have been inhabited, at least since prehistoric times, except as occasional refuges. 


\section{MODERN TROGLODYTES}

But there is a rock hermitage at Dale Abbey that has been lived in till recently, and when Mr. St. John Hope was excavating the Abbey ruins, one of his workmen informed him that he had been born and bred in it.

A writer in The Cornish Magazine gives the following account of some Cornish cave-dwellers.

"People in the habit of frequenting the shore of Whitsand Bay, between Lore and Dowderry, are familiar with the sight of a couple of women moving about among the rocks exposed at low tide. They are shell-fish gatherers, who live in a small cave a little to the west of Seaton. The illustration shows almost the extent of this cleft in the shady cliff, and any one who examines the place must wonder how two human beings can exist there. Along one side is a strip of sand, and from that the floor slopes upwards at an angle of about sixty degrees. Whether by years of practice the women have attained such perfection in the art of balancing their bodies that they go to sleep on the slanting rock without fear of falling, or whether they rest on the sand (wet when I saw it from a late storm), I was not informed; but it is evident that they know no comfort at any time. When I came suddenly upon the cave one morning in October, the smouldering ashes of a drift-wood fire, a kettle, a teapot, and two cups were dotted about just inside. Further up the floor their 'cupboards'-a couple of iron boilers-were standing, and in a niche near the fre was a pipe-short, dark, and odorous. The women who have made this their dwelling are Irish widows, "born in Ireland and married in Ireland,' as one of them said. 'They are between fifty and sixty years of age, and for the last thirty years have manager to gain a subsistence by gathering limpets week after week and taking them to Plymouth. When the sea is rough they obtain few or no fish, but under favourable circumstances the two sometimes get fourteen shillings a week between them. In fine weather, when from 


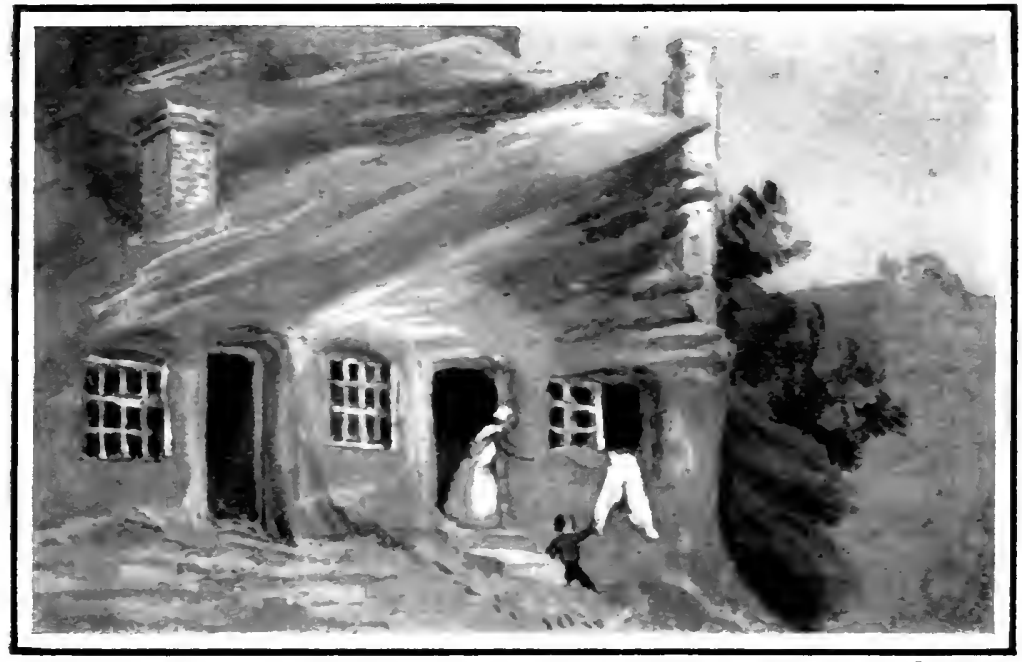

DRAKELOW IX KINTER, SHROPSHIRE

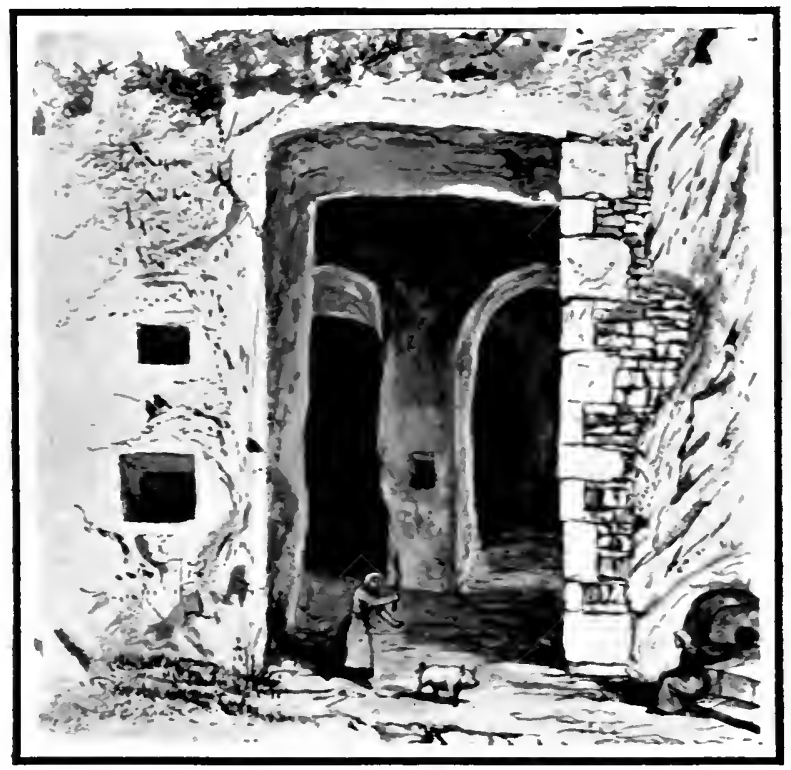

ALBETERRE

$S, B, G$.

One of the subterranean excavations at Aubeterre on the Dronne, serving as stables, storehouses, etc. At the side on the right may be seen an oven for bread, scooped out of the rock. 


\section{MODERN TROGLODY'TES}

Rame Head to Looe Island the sea lies calm and glistening under a summer sky, this smoke-blackened cave is an uninviting hovel; and in the winter, especially when there is a gale from the south-east, the women must be almost blown out of the hollow or frozen to death. On such occasions they are forced to leare the cave, and then they go to a disused pigsty near by. In talking with them while they dexterously chipped limpets from the weedmantled rocks, I mildly remarked that workhouses were now very comfortable. Inmediately the younger woman stood erect, and with something akin to pride and determination, exclaimed in a voice more than tinctured by the Irish patois, "Never, sir, will us go to the workhouse while us can get as much as an crust in twenty-four hours." Hitherto I had seen her only in a stooping attitude, and I was surprised to see how tall a woman she was, and what strength of character was indicated by her features. As she stood there amongst the sea-weed, with feet and legs bare, and her hair confined by a handkerchief, beating the palm of one hand with the knuckles of the other to emphasise her words, it dawned upon me that I had named the thing against which these two women had fought grimly for more than a quarter of a century." 1

Sir Arthur Mitchell describes some troglodytes in Scotland. ${ }^{2}$ "In August 1866, along with two friends, I visited the great cave at the south side of Wick Bay. It was nine at night, and getting dark when we reached it. It is situated in a cliff, and its mouth is close to the sea. Very high tides, especially with north-east winds, reach the entrance and force the occupants to seek safety in the back part of the care, which is at a somewhat higher level than its mouth.

"We found twenty-four inmates-men, women, and

1 The Cornish Magazine, i. (18i8), pp. 394-5.

2 "The Past in the Present," Edin. 1880, pp. 73-7. 


\section{MODERN TROGLODYTES}

children-belonging to four families, the heads of which were all there. They had retired to rest for the night a short time before our arrival, but their fires were still smouldering. They received us civilly, perhaps with more than mere civility, after a judicious distribution of pence and tobacco. 'lo our great relief, the dogs, which were numerous and vicious, seemed to understand that we were welcome.

"The beds on which we found these people lying consisted of straw, grass and bracken, spread upon the rock or shingle, and each was supplied with one or two dirty, ragged blankets or pieces of matting. Two of the beds were near the peat-fires, which were still burning, but the others were further back in the cave where they were better sheltered.

"On the bed nearest the entrance lay a man and his wife, both absolutely naked, and two little children in the same state. On the next bed lay another couple, an infant, and one or two elder children. Then came a bed with a bundle of children, whom I did not count. A youngish man and his wife, not quite naked, and some children, occupied the fourth bed, while the fifth from the mouth of the cave was in possession of the remaining couple and two of their children, one of whom was on the spot of its birth. Far back in the cave-upstairs in the garret, as they facetiously called it-were three or four biggish boys, who were undressed, but had not lain down. One of them, moving about with a flickering light in his hand, contributed greatly to the weirdness of the scene. Beside the child spoken of, we were told of another birth in the cave, and we heard also of a recent death there, that of a little child from typhus. The Procurator-Fiscal saw this dead child lying naked on a large flat stone. Its father lay beside it in the delirium of typhus, when death paid this visit to an abode with no door to knock at. 


\section{MODERN TROGLODYTES}

"Both men and women, naked to their waists, sat up in their lairs and talked to us, and showed no sense of shame. One of the men summoned the candle-boy from the garret, in order that we might see better, and his wife trimmed the dying fire, and then, after lighting her pipe, proceeded to suckle her child.

"In the afternoon of the next day, with another friend, I paid a second visit to this cave, when we found eighteen inmates, most of whom were at an early supper, consisting of porridge and treacle, apparently well cooked and clean. One of the women was busy baking. She mixed the oatmeal and water in a tin dish, spread the cake out on a flat stone which served her for a table, and placing the cake against another stone, toasted it at the open fire of turf and wood. This was one of three fires, all situated about the centre of the wider part or mouth of the cave, each with a group about it of women and ragged children.

"There was no table, or chair, or stool to be seen, stones being so arranged as to serve all these purposes. There was no sort of building about the entrance of the cave to give shelter from the winds, which must often blow fiercely into it. Yet this cave is occupied both in summer and winter by a varying number of families, one or two of them being almost constant tenants.

" I believe I am correct in saying that there is no parallel illustration of modern cave life in Scotland. The nearest approach to it, perhaps, is the cave on the opposite or north side of the same bay. Both of these caves $I$ have had frequent opportunities of visiting, and I have always found them peopled. Only occasional use is made of the other cares on the Caithness and Sutherland coasts. Of these, perhaps the cave of $\mathrm{Ham}$, in Dunnet parish, is the most frequented. It is the nearness to a large town which gives to the Wick caves their steady tenants. The neighbouring population is large enough to afford 


\section{MODERN 'TROGLODYTES}

room for trading, begging, and stealing - all the year round.

"The occupants of the Wick caves are the people commonly known by the name of Tinkers. They are so called chiefly because they work in tinned iron. The men cut, shape, hammer, while the women do the soldering.

"The Tinkers of the Wick caves are a mixed breed. There is no Gipsy blood in them. Some of them claim a West Island origin. Others say they are true Caithness men, and others again look for their ancestors among the Southern Scotch. They were not strongly built, nor had they a look of vigorous bodily health. Their heads and faces were usually bad in form. Broken noses and scars were a common disfigurement, and a revelation at the same time of the brutality of their lives. One girl might have been painted for a rustic beauty of the Norse type, and there was a boy among them with an excellent head. It is possible that one or both of these may yet leave their parents, from dissatisfaction with the life they lead."

'These cave-dwellers of Wick were the offscourings of society, such as might be found in any town slum. "Virtue and chastity exist feebly among them, and honour and truth more feebly still; they neither read nor write; they go to no church, and have scarcely any sort of religious belief or worship. They know little or nothing of their history beyond what can be referred to personal recollection."

These, like the slum dwellers of a town, are recruited from outside, they do not constitute a race; they are the dregs of a race-persons who have dropped out of the line of march.

An amusing story was told by Mr. Grant Allen. A missionary society had captured, converted, and educated a black man. He was such a promising pupil, and looked so respectable in black clothes and a white tie, that he 


\section{MODERN TROGLODYTES}

was advanced to the ministry, and in due course consecrated bishop, and sent out shovel-hat, lawn sleeves, rochet, and all complete, to the Gold Coast, to found a church there among the natives.

Now Bishop Black got on for a little while decorously; but one day the old wild blood in him boiled up-away went shovel-hat and boots, he peeled off his gaiters and knee-breeches, tore his lawn sleeves to rags, and dashed off a howling sarage, stark naked, to take to himself a dozen wives, and to go head-hunting. What was born in the bone would come out in the flesh.

Probably there is an underlying rein of the sarage in all of us, but it is kept in control by the restraints of habit accumulated through generations of civilisation. Yet there it is. A quiet, well-conducted dog will sometimes disappear for a few days and nights. It has gone off on a spree, to poach on its own account. Then, when it has had its fling, it returns, and is meek, docile, and orderly as before.

There is something of this in man. He becomes impatient of the trammels of ordinary life, its routine and matter-of-fact, and a hunger comes over him for a complete change, to shake off the bonds of conrentionality, escape the drudgery of work, and live a free, wild life. Among many this takes the form of going to the Colonies or to Wild Africa or Western Canada, to shoot game, to camp out, and be a savage for a while. Among the artisan class it takes another form-the great army of tramps is recruited thus. 'The struggle to maintain a family, the dry uninteresting toil, drives the man into a fit of impatience, and he leaves his work, his wife and bairns, and becomes a wanderer; idle, moving on from place to place, never starving, never very comfortable-in dirt and idleness, and often in drink-but with no ties, and going here, there, and every where as he lists. 


\section{MODERN TROGLODY'TES}

Not many years ago there was a man who lived by the Devil's Dyke, on the South Downs of Sussex, in a shelter under a hedge, picking up coppers from visitors to the Dyke, dressed like Ally Sloper, but living in a manner more squalid and under a worse shelter than would be endured by most savages in the darkest parts of Africa. What his history was no one knew.

It is now somewhat longer since a medical man, in an excess of impatience against civilisation, constructed for himself a hovel out of hurdles thatched with reeds, in South Devon. He lived in it, solitary, speaking to no one. Occasionally he bought a sheep and killed it, and ate it as the appetite prompted, and before it was done the meat had become putrid. At length the police interfered, the stench became intolerable in the neighbourhood, as the hovel was by the roadside. The doctor was ordered to remove, and he went no one seems to know whither.

In Charles the First's time there were men living in the caves and dens of the ravines about Lydford in South Devon. 'They had a king over them named Richard Rowle, and they went by the name of the Gubbins. William Browne, a poet of the time, wrote in 1644 :-

"The town's enclosed with desert moors,

But where no bear nor lion roars,

And naught can live but hogs;

For all o'erturned by Noah's flood,

Of fourscore miles scarce one foot's good,

And hills are wholly bogs.

And near hereto's the Gubbins' cave ;

A people that no knowledge have

Of law, of God, or men ;

Whom Cæsar never yet subdued,

Who've lawless liv'd; of manners rude;

All savage in their den. 


\section{MODERN TROGLODYTES}

By whom, if any pass that way,

He dares not the least time to stay,

For presently they howl;

Upon which signal they do muster

Their naked forces in a cluster

Led forth by Roger Rowle."

I extract the following from the Daily Express of May 10,1910 :-

"It was stated at an inquest held on Richard Manford at Market Drayton yesterday, that he was over eighty years of age, and had for the greater part of his life dwelt in a cave near Hawkstone. He was found dying by the roadside."

Elsewhere ${ }^{1}$ I have given an account of the North Devon savages, to whom Mr. Greenwood first drew attention. Till a very few years ago there lived on the Cornish moors a quarryman - he nay be living still for aught $I$ have heard to the contrary-in a solitary hut piled up of granite. He would allow no one to approach, threatening visitors with a gun. His old mother lived with him. By some means the rumour got about that she was dead, but as the man said nothing, it was not till this rumour became persistent that the authorities took cognisance of it, and visited the hovel. They found that the old woman's bed had been a hole scooped out of the bank that formed part of the wall; that she had been dead some considerable time, and that her face was eaten away by rats. Daniel Gumb was a stone-cutter who lived near the Cheese Wring on the Cornish moors in the eighteenth century. He inhabited a cave conlposed of masses of granite. It is an artificial cell about twelve feet deep and not quite that breadth. The roof consists of one flat stone of many tons weight. On the right hand of the entrance is cut "D. Gumb," with a date

1 “An Old English Home," Methuen, 1898. 


\section{MODERN 'TROGLODY'TES}

1733 (or 5). On the upper part of the covering stone channels are cut to carry off the rain. Here he dwelt for several years with his wife and children, several of whom were born and died there.

How instinctively the man of the present day will revert to primitive usages and to the ground as his natural refuge may be illustrated by a couple of instances. Mr. Hamerton, in "A Painter's Camp," says that near Sens on a height is a little pleasure-house and the remnant of a forgotten chapel dedicated to $\mathrm{S}$. Bondus. This belonged of late years to a gentleman of Sens who was passionately attached to the spot. "Near my tent there is a hole in the chalk leading to the very bowels of the earth. A long passage, connecting cells far apart, winds till it arrives under the house, and it is said that the late owner intended to cut other passages and cells, but wherefore no man knows. One thing is certain, he loved the place, and spent money there for the love of it. Night and day he came up here from his little city on the plain, sat in his pleasant octagon room, and descended into his winding subterranean passages, and hermit-like visited the hollow cells." On his death he bequeathed it to the Archbishop of Sens. ${ }^{1}$

Another instance is from our own country. Mr. L. P. Jacks' very remarkable book, "Mad Shepherds," gives an account of one 'Toller of Clun Downs, who went deranged, took to the moors and lived for a considerable time, stealing sheep and poultry. "Beyond the furthest outpost of the Perryman farm lie extensive wolds rising rapidly into desolate regions where sheep can scarcely find pasture. In this region Toller concealed himself. About two miles beyond the old quarry, on a slaty hillside, he found a deep pit; and here he built himself a hut. He made the walls out of stones of a ruined sheepfold; he roofed them with a sheet of corrugated iron, stolen from the outbuildings of 1 "A Painter's Camp," Lond, 1862, Bk, iii. c. 1. 


\section{MODERN TROGLODYTES}

a neighbouring farm, and covered the iron with sods; he built a fireplace with a flue, but no chimney; he caused water from a spring to flow into a hollow beside the door. Then he collected slates, loose stones and casks; and by heaping these against the walls of the hut, he gave the whole structure the appearance of a mound of rubbish. Human eyes rarely came within sight of the spot; but even a keen observer of casual objects would not have suspected that the mound represented any sort of human dwelling. It was a masterpiece of protective imitation.... His implements were all of flint, neatly bound in their handles with strips of hide. 'There was an axe for slaughter, a dagger for cutting meat, a hammer for breaking bones, a saw and scrapers of various size-the plunder of some barrow on Clun Downs." There Toller lived for several months, and there he died, his hiding-place being known to one other shepherd, and to him alone; and there after his death he was buried. "My 'usband dug his grare wi' his own hands," said the widow of this shepherd, "close beside the hut, and buried him next day. He put the axe and slings just as he told him, wi' the stones and all the bits of flint things as he found 'em in the hut." 1

1 “Mad Shepherds, and other Human Studies," Lond. 1910, p. 137 et seq. 


\section{CHAPTER III}

\section{SOUTERRAINS}

I the year 1866 the Prussian Army of the Elbe broke into Bohemia, when it was found that the inhabitants of a certain district had vanished along with their cattle and goods, leaving behind empty houses and stables. It had been the same during the Thirty Years' War, and again in the Seven Years' War, when the invaders found not a living soul, and contented themselves with destroying the crops and burning the villages and farms. Even the Government officials had disappeared. Whither had they gone? Into the rock labyrinths of Adersbach and Wickelsdorf, each accessible only through a single gap closed by a door. The mountain of what the Germans call Quadersandstein is four miles long by two broad, and was at one time an elevated plateau, but is now torn into gullies, forming a tangled skein of ravines, wherein a visitor without a guide might easily lose himself. The existence of this labyrinth was unknown save to the peasants till the year 1824, when a forest fire revealed it, but for some time it remained unexplored. ${ }^{1}$

As Adersbach and Wickelsdorf lie on the frontier of Bohemia and Silesia, the existence of this region of cliffs and natural refuges had been kept secret by the natives, who looked upon it as a secure hiding-place for themselves and their chattels when the storm of war swept over the Riesen Gebirge. But the fatal fire of 1824 betrayed their secret to the world, and after a little hesitation, thinking to

1 It had indeed been mentioned by Dr. Kausch in bis Nachrichten über Böhmen, 1794 ; but he lamented its inaccessibility. 


\section{SOUTERRAINS}

make profit out of it as a show-place, paths were cut through it, and it was advertised in 1847. When, in 1866, the Prussians passed by, they incurred neither the risk nor the trouble of hunting out the refugees from their place of concealment.

The rocks run up to 200 feet, the loftiest being 280 feet. They assume the most fantastic shapes. The passage through the fissures is so narrow that in some places it can be threaded by one man alone at a time, the others following in single file. A rivulet, clear as crystal, traverses the network of gullies, and in one place forms a tiny cascade. One nook is called the Southern Siberia, because in it the snow lies unmelted throughout the summer.

At intervals the rocks fall back and form open spaces, and at one describe an amphitheatre upon a vista of rolling forest.

But if this "petrified forest," as it has been called, served as a refuge for the peasants in troublous times, it has also been employed by brigands as their fastness whence to ravage the country and render the roads perilous. But of their exploits I shall have more to say in the chapter on robber-dens.

Caverns, as well as chasms, have always served this same purpose.

There is something remarkably human and significant in the prophecy of Isaiah relative to the coming of the Judge of all the earth: "They shall go into the holes of the rocks, and into the caves of the earth, for fear of the Lord, and for the glory of his majesty." And in the Book of Revelation: "And the kings of the earth, and the great men, and the rich men, and the chief captains, and the mighty men, and every bondman, and every free man, hid themselves in the dens and in the rocks of the mountains."

As the first men found their refuges and homes in caves 71 


\section{SOUTERRAINS}

and rock shelters, so the last men, with the instinct implanted in them from the first and never eradicated, will fly to the earth as a hiding-place, just as a frightened child flies to the lap of its mother.

When Ahab persecuted the prophets, Obadiah hid them by fifties in a cave. After the battle of Bethhoron the five kings of the Amorites hid themselves in the cave of Makkedah. When the Midianites oppressed Israel, the latter "made them the dens which are in the mountains, and caves and strongholds." From the Philistines "the people did hide themselves in caves and in thickets and in high places, and in pits." 'Twice did Elijah take refuge in a cave.

What took place in Palestine, took place in every part of the world wherever there are limestone and chalk and volcanic breccia and sandstone. It would seem as though a merciful Providence had not only provided the first shelters for man against the inclemency of the weather, but had also furnished him with places of secure refuge against the violence of his fellow-man. As sure as the rabbit runs to its hole on the sight of the sportsman, so did the oppressed and timorous when the slayer and the maruuder appeared.

In the South of France, where caves abound, the unhappy Gauls fled from Cæsar and concealed themselves in them. $\mathrm{He}$ bade his lieutenant Crassus wall up the entrances. When the Armenians fled before Corbulo-_fuere qui se speluncis et carissima secum abderent"-he filled the mouths of the caverns with faggots and burned them out. ${ }^{1}$

When Civilis rose in insurrection against Vespasian, he was joined by a young native, Julius Sabinus from Langres, who boasted that, in the great war with the Gauls, his great-grandmother had taken the fancy of Julius Cæsar, and that to him he owed his name.

$$
\begin{aligned}
& 1 \text { Tacit., "Annals," xvi. } 23 . \\
& 72
\end{aligned}
$$




\section{SOUTERRAINS}

After the death of Nero, the Druids had come forth from the retreats where they had remained concealed since their proscription by Claudius, and proclaimed that "the Roman Empire was at an end, and that the Gallic Empire was come to its birth." Insurgents rose on every side, and Julius Sabinus assumed the title of Cæsar. War broke out; confusion, hesitation, and actual desertion extended through the Colonies, and reached the legions. Several towns submitted to the insurgents. Some legions yielding to persuasion, bribery, or discontent, killed their officers and went over to the rebels. The gravity of the situation was perceived in Rome, and Petilius Cerealis was despatched to crush the revolt. The struggle that ensued was fierce but brief, and Civilis was constrained to surrender. Vespasian being disinclined to drive men or matters to an extremity, pardoned him ; but no mercy was to be extended to Julius Sabinus. After the ruin of his cause, Sabinus took refuge underground in one of those retreats excavated in the chalk beneath his villa, and two of his freedmen were alone privy to the secret. The further to conceal him, they set fire to his house, and gave out that he had poisoned himself and that his dead body had been consumed in the flames. His young wife, named Eponia, was in frantic despair at the news; but one of the freedmen informed her of the place of his retreat, and advised her to assume the habit and exhibit the desolation of widowhood, so as to confirm the report they had disseminated. "Well did she play her part," says Plutarch, " in this tragedy of woe." She visited her husband in his cave at night, and left him at daybreak, but at last refused to leave him at all. At the end of seven months, hearing talk of the clemency of Vespasian, she set out for Rome taking her husband with her, disguised as a slave, with shaven head and a dress that rendered him unrecognisable. But friends who were in her confidence dissuaded her from prosecuting the journey. The imperial clemency was not 


\section{SOUTERRAINS}

a quality to be calculated upon with confidence. They accordingly returned to their subterranean abode. There they lived for nine years, during which, " as a lioness in her den," says Plutarch, "Eponia gave birth to two young whelps, and suckled them at her own breast." At length they were discovered, and Sabinus and his wife were brought before Vespasian.

"Cæsar," said Eponia, showing him her children, "I conceived and suckled them in a tomb, that there might be more of us to entreat thy mercy." But the Emperor was not disposed to be clement to one who pretended to inherit the sacred Julian blood, and he ordered Sabinus to be led to the block. Eponia asked that she might die with her husband, saying: "Cæesar, do me this grace, for I have lived more happily underground and in darkness than thou hast done in the splendour of thy palace."

Vespasian fulfilled her desire by sending her also to execution; and Plutarch, their contemporary, expressed the general feeling in' Rome, when he adds: "In all the long reign of this Emperor there was no deed done so cruel, and so piteous to look upon; and he was afterwards punished for it, for in a brief time all his posterity was cut off."

In 731 the Saracens, masters of the peninsula, poured over the Pyrenees, and entered the Septimania. They had come not to conquer and pillage, but to conquer and occupy. They had brought with them accordingly their wives and children. They took Narbonne, Carcassone and Nimes, besieged Toulouse, and almost totally destroyed Bordeaux. Thrusting up further, they reached Burgundy on one side and Poitou on the other. Autun was sacked, and the church of S. Hilary in Poitiers given to the flames. The Christians, wherever met with, were hewn down with their curved scimitars; they passed on like a swarm of locusts leaving desolation in their wake. Those of the natives who 


\section{SOUTERRAINS}

escaped did so by taking advantage of the subterranean refuges either natural or artificial that abounded. And that they did so is shown by the relics of Merovingian times that have been found in them.

The Mussulmans were routed at Poitiers by Charles Martel. Three hundred thousand Saracens, say the old chroniclers, with their usual exaggeration, fell before the swords of the Christians. The rest fled under the walls of Narbonne.

Between 752 and 759 Pepin the Short resolved on the conquest of Septimania, i.e. Lower Languedoc. The Goths there had risen against the Arabs and appealed for his aid. Nimes, Agde, Beziers, Carcassonne opened their gates, but Narbonne resisted for seven years. When it surrendered in 759, the Empire of the Franks for the first time touched the Eastern Pyrenees. Pepin now picked a quarrel with Waifre, Duke of Aquitaine, and crossing the Loire made of the unhappy country a hunting-ground for the Franks. He delivered the land over to a systematic devastation. From the Loire to the Garonne the houses were burnt, and the trees cut down. "The churches, the monasteries, and secular buildings were reduced to ashes. Vineyards and fields were ravaged, and the inhabitants put to the edge of the sword. Only a few strong places escaped the fury of the soldiers. . . . Ihe city of Cahors fell into the power of the conqueror and was reduced to the same pitiable condition into which it had been brought by the Saracens. The inhabitants of Quercy who survived owed this to the subterranean retreats which they had made and to the caverns in the rocks that had served them as refuges during the incursion of the infidels. The principal caves are situated on the Banks of the Lot at Cami, Luzech, Vers, Bouzier, S. Cirq, La Toulsanie, Larnagol, Calvignac, S. Jean de Laur, Cajarc and Laroque- Toirac, to above Capdenac; on the banks of the Célé, at Roquefort, Espagnac, Brengues, 


\section{SOUTERRAINS}

S. Sulpice, Marcillac, Liauzun, Sauliac, Cabrerets; on the banks of the Dordogne at Belcastel, La Cave, Le Bon Sairon, Mayronne, Blansaguet, Montvalent, Gluges, Saint Denis, \&c., and between the rivers, Autoire, Gramat, S. Cirq d'Alzou, Rocamadour, S. Martin de Vers, Crass Guillot, to Vers among the high cliffs athwart which runs the Roman aqueduct, which in certain places, behind its high walls, could shelter a great number of the inhabitants. These caverns are still called Gouffios, Gouffieros, or Waiffers, from the name of Duke Waifre. ' 'They were closed by a wall, of which there are remains at Canis, at Brengues, and at S. Jean de Laur, on the rock that commands the abyss of Lantoui. This last cavern is the most remarkable of all, as it is at but a little distance from the castle of Cénevières, which was one of the principal strongholds of the Duke of Aquitaine in Quercy." 2

'The wretched country had to suffer next from the expedition of the Northmen, who pushed up every river, destroying, pillaging, and showing no mercy to man or beast. 'Ihe most redoutable of these pirates was Hastings, who ravaged the banks of the Loire between 843 and 850 , sacked Bordeaux and Saintes and menaced 'Tarbes. In 866 he was again in the Loire, and penetrated as far as Clermont Ferrand. There seemed to be no other means of appeasing him than by granting him the country of Chartres. But this did not content his turbulent spirit, and at the age of nearly seventy he abandoned his county to resume his piracies.

An Icelandic Saga relating the adventures of a Viking, Orvar Odd in Aquitaine, describes how he saw some of the natives taking refuge in an underground retreat, and how he pursued and killed them all. ${ }^{3}$

1 Lacoste's derivation is absurd; Gouflieros comes from Gouffre, a chasm.

${ }^{2}$ Lacoste, Histoire lc Quercy, Cahors, 1883, i. pp. 267-8.

3 Fornmanna Sögur, Copenhagen, 1829, ii. p. 229. 


\section{SOU'TERRAINS}

In the persecution of the Albigenses at the instigation of Pope Innocent III. the unfortunate heretics fled to the caves, but were hunted, or smoked out and massacred by the Papal emissaries. Nevertheless, a good many escaped, and in 1325, when John XXII. was reigning in Avignon, he ordered a fresh battu of heretics. A great number fled to the cave of Lombrive near Ussat in Ariège. It consists of an immense hall, and runs to the length of nearly four miles. In 1328 the papal troops, to save themselves the trouble or risk of penetrating into these recesses after their prey, built up the entrance, and left from four to five hundred Albigenses along with their bishops to perish therein of starvation. Of late years the bones have been collected, removed, and buried. From 1152, the Bordelois, Saintonge, Agenois, Perigord, and the Limousin were nominally under the English crown. But the people did not bear their subjection with patience, and often rose in revolt, and their revolts were put down with ferocity. As to the Barons and Seigneurs of Guyenne, they took which side suited their. momentary convenience, and shifted their allegiance as seemed most profitable to then. But the worst season was after the Treaty of Bretigny in 1360 , when a vast part of France, from the Loire to the Pyrenees was made over to the English. 'The Hundred Years' War was the consequence, of which more shall be said in the fifth chapter. Froissart describes the condition of the country: "Matters were so woven together there and the lords and knights were so divided, that the strong trampled down the weak, and neither law nor reason was measured out to any man. Towns and castles were intermixed inextricably; some were English, others French, and they attacked one another and ransomed and pillaged one another incessantly."

Under these circumstances it may well be understood that if Nature herself had not of her own accord furnished the miserable, harassed people with refuges, they would them- 


\section{SOU'IERRAINS}

selves have contrived some. As we shall see they did this, as well as make use of the natural provision supplied for their safety.

Of refuges there are two kinds, those patiently and laboriously excavated under the surface of the soil, and those either natural or contrived high up in the face of inaccessible cliffs.

Each shall be dealt with; they are different in character. The town of Saint Macaire on the Garonne is walled about. But the walls did not give to the citizens all the security they desired; the ramparts might be battered down, escaladed, or the gates burst open. Accordingly they excavated, beneath the town, a complete labyrinth of passages, chambers, halls, and store-rooms into which they might either retreat themselves or where they might secure their valuables in the event of the town being sacked.

At Alban in Tarn there are retreats of like nature under the houses, refuges at one time of the persecuted Albigenses, at another of the inhabitants secreting themselves and their goods from the Routiers. At Molières in Lot they are beneath the church, and the approximate date can be fixed when these were excavated, as Molières was founded in 1260 .

Bourg-sur-Garonne is likewise honeycombed with such retreats, so is Aubeterre, of which more hereafter. The network of underground galleries and chambers is now closed, because the soft chalk rock has fallen in in several places. At Ingrandes-sur-Vienne there are three groups of these refuges, extending to a considerable distance. At Chateau Robin in the 'Touraine is a chalk cliff that rises above the road to the height of sixty feet and is crowned by a tumulus. In its face are two sets of caves, one superposed over the other. This upper cave or shelter is the most ancient, and dates from prehistoric times, but has been utilised much later. The lower cave is exposed by the 78 


\section{SOU'TERRAINS}

widening of the road which has obliterated the original face of the cliff and the original entrance, having made three openings by cutting into a chamber to which formerly there was but a single entrance. The plan of the excavation was made by M. Antoine and communicated to the "Bulletin de la Société Archéologique de Touraine," in 1858, but I will give a description from the pen of a later visitor.

"The upper rock-shelter has been dug out or enlarged with a pick. The stone is a tender tufa, containing a quantity of little cores of black silex, giving it a spotty appearance. It was quite impossible to cut the stone so as to give a smooth surface.

"The most mysterious portion, however, of the whole is certainly the lower range of vaults, a subject of terror to the inhabitants of the neighbourhood, who believe them to be the abode of the devil. Some persons have visited them, but very few have explored them. Having calculated on the assistance of a poacher of some repute as a fearless fellow, he pointblank refused to accompany me when I proposed an expedition into the cave. I applied to a man of more resolution, a landowner at Arzay-le-Rideau, who readily volunteered his assistance; but when we arrived on the spot, contented himself with showing me the entrance, but declined to adventure himself within, though he assured me he had visited the interior some five-and-twenty or thirty years ago.

"These excavations have now several openings upon the road; the two principal are accessible enough, if one is suitably dressed, for beyond the entrance one has to crawl on hands and knees, and this is but the initiation of other discomforts.

"The entrances are, so to speak, in the ditch of the road to Azay. The most practicable of them, and that by which M. Antoine and I penetrated, is the easternmost of the three, and is marked $\mathrm{A}$ on the plan, and it gives access to a 


\section{SOUTERRAINS}

small triangular chamber $\mathrm{C}$; but the entrance is so low that one can only enter on one's knees or in a doubled position. Further on it is loftier. On advancing to the end one leaves

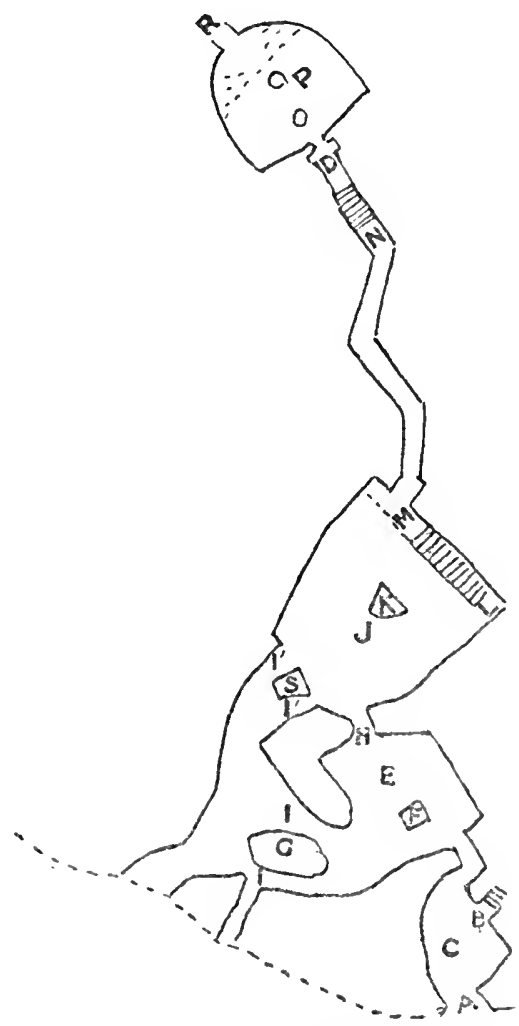

Plan of the Refuge of Château Robin

(Indre et Loire). on the right a sort of staircase $B$ cut in the rock, but very worn, which formerly ascended spirally to the upper cave, but is now without issue.

"At the bottom of the chamber $\mathbf{C}$ a very narrow passage turns at a right angle and gives access to a large hall $\mathrm{E}$ that is sustained by a pillar F. This pillar is three feet square and the vaulted chamber may be 15 to 18 feet square and 5 feet high. On the left a great pier $G$ allows of two passages I I which lead to the other openings that gape upon the road, and turning to the right give access to the further depths of the underground retreat. A passage $\mathrm{H}$ is, however, the most direct means of communication between the cavern $\mathrm{E}$ and the larger hall $\mathrm{J}$ to which also access is obtained through the openings I I separated by the pillar $\mathbf{S}$.

"'The caver'n $\mathrm{J}$, the largest of all, is 25 feet long by 15 feet wide at the one end and 24 feet at the other. It is supported by the pillar $\mathbf{K}$, shaped to suit the widening of 80 


\section{SOUTERRAINS}

the hall. At the bottom of this chamber is a staircase $\mathrm{I}$, descending from the floor and without any breastwork to protect it, and therefore dangerous, as it goes down 6 feet, and is but about a foot and a half wide. 'This staircase is 12 feet long, and the passage $\mathbf{M}$ that is a continuation of it is hardly more than 4 feet high, at the entrance, and is nearly 20 feet long, so that one has to creep along it, bent double, assisted by one's hands.

"In this position it is absolutely impossible for one to turn round, so narrow is the passage. At this point a difficulty that is not anticipated arrests many a visitor. Water rises through the stones that form the floor and contributes to reduce the height of the gallery. If one elects to continue, there is no choice but to take a bath that reaches to one's middle. At a distance of nearly 7 feet comes a right angle, and the passage goes on for 6 feet, then turns to the left by an obtuse angle and pursues its course for 12 feet, then again turns to the right by another obtuse angle, and for 15 feet more one is still half under water, till $\mathbf{N}$ is reached, after which the level of the floor rises, as does also the ceiling; one is able to stand erect alongside of another person. In face of one, the wall is cut perpendicularly and seems abruptly to close the passage. However, at a few inches above the soil is a little opening $\mathrm{D}$, formed like the mouth of an oven, and giving indications of a space beyond. In diameter it is about 1 foot 6 inches; by crawling through this hole, an achievement difficult to accomplish, as one cannot even use the elbows to work one's way forward, the explorer descends into a semicircular hall $P$ whose vault is arched and is supported by two oval pillars, 7 feet high. The hall is 24 feet deep and 18 feet wide at the entrance, and is rounded at the further extremity. The soil in this chamber is encumbered with stones and rubbish thrown in from an opening at $R$, which seems to communicate with other subterranean excavations." 


\section{SOUTERRAINS}

Nothing was found in these chambers and passages that could give an approximate date, but in the upper "abris" was some Gaulish pottery. The water that had half filled the lower passage is due to the river having been dammed up for a mill, and so having raised the level considerably. Originally the passage was certainly dry.

Although this souterrain réfuge is curious, yet it does not present some of the peculiarities noticeable in others-that is to say, elaborate preparations for defence, by contriving pitfalls for the enemy and means of assailing him in flank and rear.

'The usual artifice for protection was this. The entrance from without led by a gallery or vestibule to an inner doorway that opened into the actual refuge. 'The passage to this interior doorway was made to descend at a rapid incline, and as it descended it became lower, so that an enemy entering would probably advance at a run, and doubled, and would pitch head foremost into a well, from 20 to 30 feet deep, bottle-shaped, sunk in the floor immediately before the closed and barred door, and which was gaping to receive him. Such a well-mouth would usually have a plank crossing it, but in time of danger this plank would be removed. To make doubly sure of precipitating the assailant into it, a sidechamber was contrived with slots commanding the doorway, through which slots pikes, spears and swords could be thrust.

Beside these contrivances there were also lateral recesses in which the defenders might lurk in ambush, to rush forth to hew at the enemy, or at least to extinguish his torch. Almost invariably these hypogees have two exits or entrances, so that those within could escape by one should the enemy force the other, or endeavour to smoke them out. Moreover, to keep up a circulation of air, and to obviate the contingency of being smoked out, these underground retreats are almost invariably supplied with ventilating shafts. The marks made by the implements 


\section{SOUTERRAINS}

employed in hewing the rock are always distinctly recognisable. Moreover within, sunk in the floor, are silos for the storage of grain, the soil often somewhat higher about their orifices than elsewhere, and sometimes provided with covers. Niches for lamps may be seen, also cupboards for
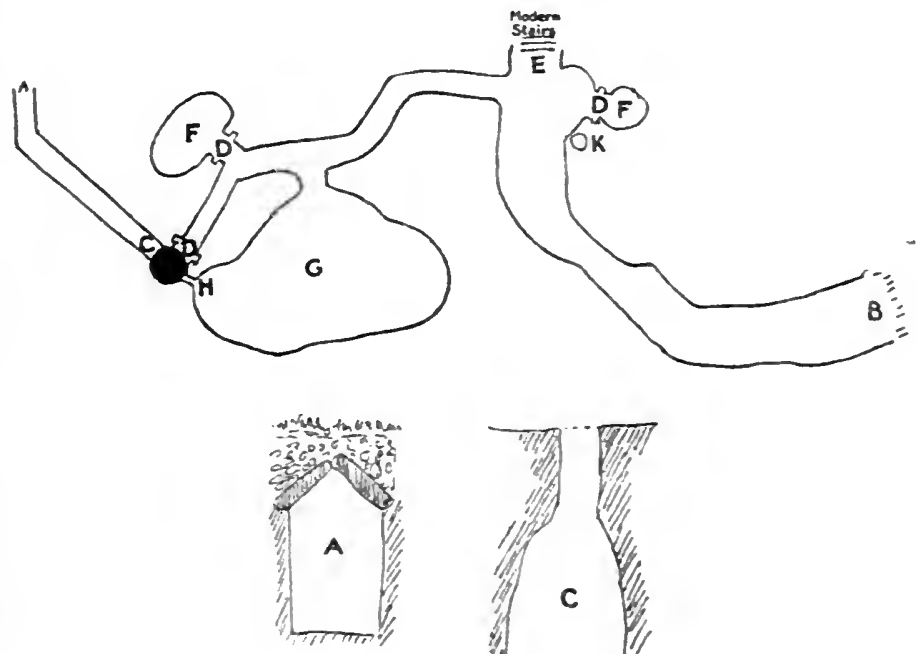

Sections.

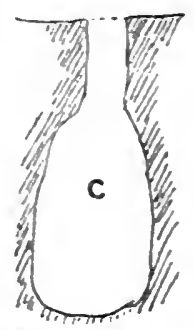

Chateau of Fayrolle (Dordogne).

A. Entrance.

B. Continuation, anexplored.

C. Shaft.

DD. Doorways.

E. Modern entrance.
FF. Store chambers.

G. Large chamber.

H. Slot for stabbing assailants.

K. Fentilating shait.

provisions, in which have been found collections of acorns, walnuts, hazel-nuts and chestnuts carbonized by age.

A typical souterrain réfuge is that of the Château de Fayrolle, not far from Riberac on the Dordogne.

It was accidentally discovered when the proprietor was levelling for terraces and gardens. A glance at the plan will save a description. 


\section{SOUTERRAINS}

A refuge at $\mathrm{S}$. Gauderic has been explored. The region is one of lacustrine deposits called the Sandstone of Carcassonne; it is friable, argilaceous marl. The opening into the hypogee is in the middle of a field, and there are no indications around of the deposition of the material extracted in the formation of the retreat, so as to betray its presence. The visitor descends by a dozen steps into a long corridor, sinuous, and inclining downwards, about 1 foot 8 inches wide, and 4 feet 6 inches high. The passage exhibits rebates in several places, into which door-frames had been fitted, as well as square holes into which the beams were run that fastened the doors. It leads past several side-chambers into which the defenders might retire, so as to burst forth suddenly and unexpectedly on the foe, smite him and extinguish any torch he bore. The corridor leads to a rectangular hall 22 feet long and 7 feet high, vaulted and ventilated by three circular airholes, 6 inches in diameter. There are numerous silos in the floor, and fragments of coarse grey pottery turned on the wheel have been found there. ${ }^{1}$

M. L. Druyn, in his La Guyenne Militaire, Bordeaux, 1865, gives the following account of a refuge he explored. "Ascending the valley that separates the castle of Roquefort from the church of Lugasson, after having passed the village of Fauroux, one reaches, on the left side of the road, a splendid quarry of hard stone, but a few paces further on, upon the same side, the stone becomes soft. Here on the right, in a little coppice beside the road, is found a place of refuge of which I give the plan as accurately as it was possible for me to take it where one had to crawl on hands and knees, and sometimes wriggle forward lying on one's stomach, over earth that was damp and rubble fallen from above, and in corridors completely filled by one human body.

"'The entrance is at $A$ on a level with the soil outside against the rock, but this cannot have been the original

- Révue de l'Art Chretienne, Paris, 1868, p. 498 et seq. 


\section{SOUTERRAINS}

place of admission. It is a round hole and very narrow. The real entrance was at $K$, where one can distinguish a circular opening like the orifice of a silo, but which is now in the open and is choked with stones; or else at the end of the gallery H B. The chamber $\mathrm{Y}$ containing silos for preservation of grain must have been the furthest extremity. It is 6 feet 3 inches high, and the floor is higher above the

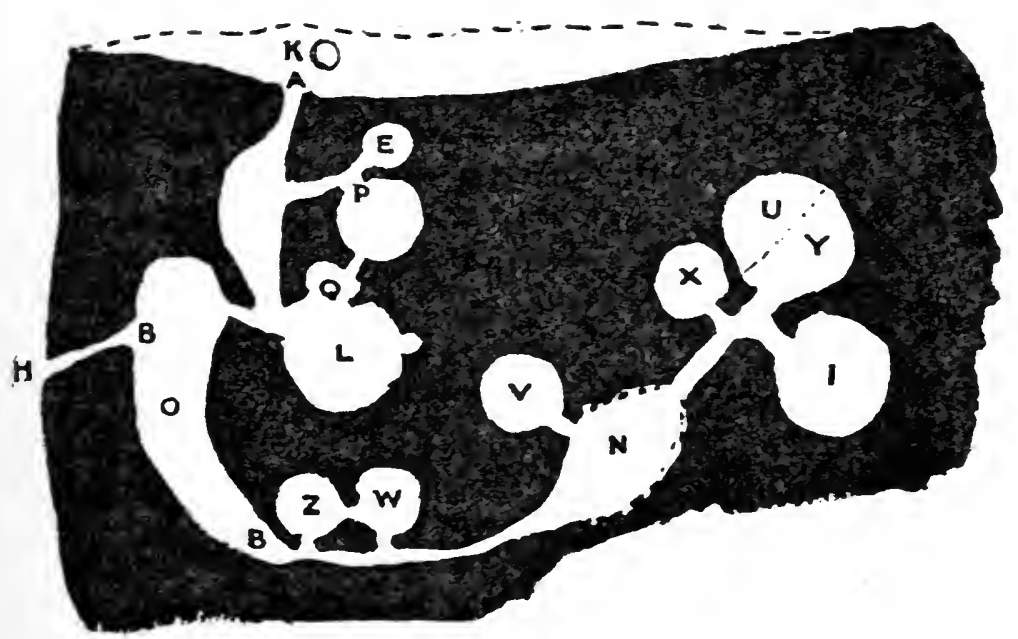

Clusean de Fauroux.

mouth of the silos than elsewhere. The carern is hewn out of the rock. All the chambers are circular. They are vaulted for the most part in the form of low cupolas. The domes of some are so low that one cannot stand upright in them. The corridors are still lower than the chambers, and one can only get along them by creeping. The extremities of the corridors and the entrances to the chambers had doors originally. One can see the notches for the reception of the closing beams. I saw no trace of hinges. The passages are all arched over in semicircle."

Lacoste, speaking of the Saracen invasion and derastation 


\section{SOUTERRAINS}

of Quercy, says that " in Lower Quercy, where caverns are not common as they are in Upper Quercy, the inhabitants dug souterrains with a labour that only love of life could prompt. Three of vast extent have been discovered at Fontanes, Mondoumerc, and Olmie. That of Mondoumerc is cut in the tufa, and is about 20 feet deep. It consists of an infinity of cells, or small chambers, united by a corridor. But the vastest and most remarkable for its extent and the labour devoted on it, is that of Olmie. 'The chambers are scooped out of a very hard sandstone. In some of them are little wells or reservoirs that were filled with water as a precaution against thirst, if refugees were obliged to remain long in this asylum. The passages, with their turns, constitute a veritable labyrinth whence it would be hard to find one's way out without the assistance of a guide."

The entrance to these hiding-places was either under a ledger stone in a church, or through a cellar, or half-way down a well, or in a thicket.

It must be remembered that it was the duty of every feudal seigneur to provide for the safety of his vassels, and the security of their goods. Consequently a great number of such souterrains are under castles or in the grounds of a feudal lord. The rock on which his towers stood was often drilled through and through with galleries, chambers, and store places, for this purpose. On the alarm being given of the approach of an army marching through the land, of a raid by a marauding neighbour, or the hovering of a band of brigands over the spot, within a few hours all this underground world was filled with ploughs, looms, bedding, garments, household stuff of every description, and rang with the bleating of sheep, the lowing of oxen, the neighing of horses, and the whimpering of women and children. At Vendôme, the rock on which stands the castle is riddled with passages and halls, access to which is obtained not from the castle, but from the town. At Lavardin by 


\section{SOUTERRAINS}

Montoire it is the same. At Paulin in Tarn is a noble castle standing on a rock 300 feet high, and in this rock are storerooms, halls, a kitchen, a winding staircase. At MontvalonTauriac, in the same department, under the castle are refuges and granaries. At Murat in Cantal is the castle of Anterroche, and the rocks about it are traversed with galleries leading to chambers containing silos. At Salles-la-Source in Aveyron, in a cleft of the plateau, is the castle of the Count of Armagnac, and here also there is the same provision. At S. Sulpice in Tarn are the remains of a castle built in 124\%, with its chapel over crypts and galleries carved out of the living stone. At Contigne, in Maine-et-Loire, is the manor of Gâtines, underneath which are souterrains that extend for a mile, with store-chambers and chapels, hewn out of the tufa. I might mention a hundred more. But all these pertain to a period before the feudal system had sunk into one of oppression, and when the rassals had confidence in their seigneur. In process of time the conditions altered, and then they contrived their own private hiding-places from their lords and masters.

The stories everywhere prevalent where there are castles, that there are under them passages connecting them with a church, a river, or another castle, are probably due to the fact of there having been these subterranean retreats intended for the use of the vassals. But when these latter ceased to look to their lords to protect them, and cast about instead to shelter themselves from their lords, the original purport of these souterrains was forgotten and misinterpreted.

One has but to look through the brief notices of towns and villages in Joanne's Departmental Geographies to see what a number of these refuges are already known to exist in France. And he records, be it remembered, only the most interesting. There are thousands more that have either not yet been discovered or remain unexplored. Some are revealed by accident; a peasant is ploughing, when his 


\section{SOUTERRAINS}

oxen are suddenly engulfed, and he finds that they have broken through the roof of one of these hiding-places. A gentleman is building his château, when in sinking his foundations he finds the rock like a petrified sponge--but not like a sponge in this, that the galleries are artificial. A paysan lets himself down his well to clean it out, as the water is foul. He finds that in the side of the shaft is the opening of a passage; he enters, follows it, and finds a labyrinth of galleries.

As an instance of the abundance of the souterrains in France, I will take the department of Vienne and give in a note below a list of the communes where they are known to be, from De Longuemar, Géographie du dep. de la Vienne, Poitiers, 1882, and also from several editions of Joanne's Geography. ${ }^{1}$

Victor Hugo, in his Quatrevingt Treise, speaking of the war in La Vendée, says: "It is difficult to picture to oneself what these Breton forests really were. They were towns. Nothing could be more secret, more silent, and more savage. There were wells round and small, masked by coverings of stones or by branches. 'The interiors at first vertical, then carried horizontally, spread out underground like tunnels, and ended in dark chambers." These excavations, he states, had been there from time immemorial. $\mathrm{He}$ continues: "One of the wildest glades of the wood at Misdon, perforated by galleries and cells, out of which came and went a mysterious society, was called 'The Great City.' 'I'he gloomy Breton forests were servants and accomplices of

1 Natural grottoes that may have served as refuges are not included. Availles, Bellefonds, Béthines, Béruges, Bonnes, Bussières, Château Garnier, Champniers, Curzay, Civeaux, Gouex, Ingrandes, S. Julien Lars, Jazneuil, Leugny-sur-Creuse, Loudun, Lautiers, Lusignan, Marnay, Mairéle-Gautier, S. Martin-Lars, S. Martin-la-Rivière, Maslou Montmorillon, Mazerolles, Mondion, Maulay, Montreuil-Bonnin, Naintré, Prinçai, Romagne, S. Remy-sur-Oreuse, Saulgé, Nouvaille, Persac, S. Savin, Sossais, Thuré, Usson, Varennes, Le Vigean, Vénièrs, Vellèches, Verrières, Venneuilsur-Biard. Several of these are under churches, others under castles. At some of these places are three or more distinct souterrains. 


\section{SOU'TERRAINS}

rebellion. The subsoil of every forest was a sort of sponge, pierced and traversed in all directions by a secret highway of mines, cells and galleries. Each of these blind cells could shelter five or six men. Usually the cover, made of moss and branches, was so artistically fashioned that, although impossible on the outside to distinguish it from the surrounding turf, it was very easy to open and close from the inside. In several of these forests and woods there were not only subterranean villages grouped about the burrow of the chief, but also actual hamlets of low huts hidden under the trees. These underground belligerents were kept perfectly informed of what was going on. Nothing could be more rapid, nothing more mysterious, than their means of communication. Sometimes they raised the cover of their hiding-places and listened to hear if there was fighting in the distance." He mentions the ability of the ambushed men to spring up, as it were, under the feet of the armies sent against them. And to show the numbers of the concealed forces, he continues: "There are in existence lists which enable one to understand the powerful organisation of that vast peasant rebellion. In Isle-etVillaine, in the forest of Pertre, not a human trace was to be found, yet there were collected 6000 men under Focard. In the forest of Meullac, in Morhiban, not a soul was to be seen, yet it held 8000 men. These deceptive copses were filled with fighters, lurking in an underground labyrinth."

On March 26, 1807, Napoleon demanded a fresh conscription of 80,000 men. This was the third levy that had been called for since the Prussian War began. The three conscriptions supplied no less than 240,000 men in seven months, and the call for the third produced consternation throughout France. The number of young men who reached the age of eighteen annually in half a year, more than the entire annual generation, had been swept off to lay their bones in the East of Europe. Great numbers of young 


\section{SOUTERRAINS}

fellows fled to the woods, caves, and secret refuges, and concealed themselves; and the gendarmes were employed in hunting them out, but not often with success unless aided by a traitor. Again in 1812, when Napoleon meditated an invasion of Russia, fresh calls were made on the male population. Every male capable of bearing arms was forced to assume them, and again, as in 1807, the young men disappeared as rabbits underground. It is quite possible that the peasants, who have found these refuges so convenient in the past, should know more about them and where they are situated than they pretend, thinking that at some future time, another revolution or another German invasion, the knowledge may prove serviceable.

And now let us turn to Picardy, perhaps the one of the ancient provinces of France most undermined. On the night of February 13, 1834, after heavy rains, a portion of the wall of the apse of the parish church of Gapennes, half-way between Aussy-le-Château and S. Ricquier, collapsed, and in the morning the inhabitants of the commune were stupefied to see the desolation of the holy place. Not only was a large breach gaping in the sanctuary, but all the walls of the chancel were fissured, and the pavement of the nave was upheaved in places and in others rent.

At first it was supposed that this was the result of an earthquake, but after a while the true cause was discovered. The church had been erected over a vast network of subterranean passages and chambers, and the roofs of some of these had given way. 'This led to an exploration, and the plan of this subterranean refuge-for such it had beenwas traced as far as possible.

But Gapennes is not the only place where such retreats exist throughout the province. Something like a hundred have been found, and more are every now and then coming to light. Indeed, it may safely be said that there is scarcely a village between Arras and Amiens and between Roye 


\section{SOUTERRAINS}

and the sea, betwixt the courses of the Somme and Authie, that was not provided with these underground refuges. The character of all is very much the same. They consist of passages communicating with square or circular chambers that served as stores. They have been described at length by M. Bouthers in Mémoires de la Société d'Archéologie du département de la Somme, Amiens, 1834, t. i.

To what date, or period rather, do they belong?

Some doubtless are of extreme antiquity, but the majority are comparatively modern. It is a significant fact that the entrance to perhaps the majority is in the sacristy of the parish church, and in that at Gapennes care was taken not to undermine the tower of the church. M. de Carpentin, who explored and reported on the excavation at Gapennes, remarks on the care taken to so distribute the chalk brought up from these passages and vaults that no heaps were anywhere visible.

"The motive that can hare induced the undertaking of such an extensive rork can only have been that necessity drove the inhabitants to create for themselves a refuge in time of war." In it he found two pieces of common pottery, a lock and a hinge of iron, some straw and leather soles of women's shoes. He adds: "At the entrance of several of the chambers the stone is worked to receive doors, and here portions of decayed wood were found. And many of the chambers had their walls blackened by smoke as of lamps."

At Naours in Somme, the underground galleries have been explored thoroughly; there are several circular chambers for stores, and corn has been found in them, also fourteen gold coins of Charles VI or Louis XIV. In all there are 201 galleries and 300 chambers and the labyrinth extends to the distance of 6000 feet. At Santerre, which possesses three of these refuges, that portion of its territory was called Territorium Sancta Libertatis.

The north-east of France, Picardy and Artois, were 


\section{SOUTERRAINS}

always exposed to attack from pirates by sea, Northmen and Saxon, and from invaders over the border. But none of these can have exceeded in barbarity that of 1635 to 1641 , when Spanish armies-the first under. John de Werth and Piccolomini, 40,000 in number, and made up of Germans, Hungarians, Croats as well as Spaniards-poured over the provinces committing the most frightful atrocities. And precisely to this period some of the refuges may be referred.

A MS. account of this invasion, by a priest of Hiermont, named Claude Goddé, leaves this in no manner of doubt. He says: "The Spaniards committed grcat outrages in Picardy, as they did later in 1658. These wars compelled the inhabitants of Hiermont in 1647 to construct the quarry which we now see. This quarry or cavern, which is a great masterpiece, was first undertaken by five or six of the inhabitants"-he gave their names. "They first of all dug out the entrance in 1647 , but owing to its having given way several times, had to be repaired, and was not completed till 1648 . The other inhabitants, seeing its great utility, wanted also to have their chambers, but they were not admitted unless they contributed to the cost of the undertaking, and to this they willingly agreed. This quarry was of great service to the inhabitants in the Wars of Louis XIV. against England, Holland, and the Empire during the years 1708, 1709, 1710 and 1711, which were the days of Marlborough. It was accordingly made by the inhabitants of Hiermont, to hide themselves, their cattle, their grain and their furniture, to preserve them from pillage by the soldiers, whether of the enemy or French. Each family had its own chamber."

In a procès of 1638 , one of those interrogated, a nun named Martha 'Tondu, stated that at Reneval and the neighbouring villages "the peasants are on the look out, and if alarmed, retire and conceal their cattle in ditches and quarries, without abandoning their houses or neglecting their agricultural work." 


\section{SOU'TERRAINS}

Some, accordingly, of these subterranean refuges are of comparatively late date; but this does not apply to all. At every period of danger, instinctively the peasants would take advantage of the nature of the chalk to form in it suitable hiding-places, and although some of the finds in these labyrinths are of recent date, others go back to the Gallo-Roman period. In the Arras and Cambrai Chronicle of Balderic (1051), we are told that in the fifth century in those parts a persecution of the Christians occurred, on the invasion of the barbarians, and that the priests celebrated the Divine Mysteries in secret hiding-places. "Many," he adds, "were suffocated in caves and in subterranean passages."

There is, in fact, evidence both from archrology and from history that these refuges were taken advantage of, and doubtless extended from a remote antiquity down to the eighteenth century.

It was not against the foreign foe only that the peasants excavated their underground retreats. Froissart paints the chivalry of his time in the brightest colours, and only here and there by a few touches lets us see what dark shadows set them off. Who paid for the gay accontrements of the knights? Who were the real victims of the incessant war's? From whom came the ransom of King John and of the nobles taken at Creçy and Poitiers? From the peasant. The prisoners allowed to return on parole came to their territories to collect the sums demanded for their release, and the peasant had to find them. He had his cattle, his plough and tumbril. They were taken from him; no more corn was left him than enough to sow his field. He knew how he would be exploited, and he hid his precious grain that was to make bread for his wife and children. The seigneur endeavoured to extort from him the secret as to where it was concealed. He exposed the man's bare feet before the fire; he loaded him with chains. But the peasant 


\section{SOUTERRAINS}

bore fire and iron rather than reveal the hiding-place. Here is Michelet's account of the seigneur in the first half of the fifteenth century. "'The seigneur only revisited his lands at the head of his soldiery to extort money by violence. He came down on them as a storm of hail. All hid at his approach. Throughout his lands alarm resounded -it was a sauve-qui-peut. The seigneur is no longer a true seigneur; he is a rude captain, a barbarian, hardly even a Christian. Écorcheur is the true name for such, ruining what was already ruined, snatching the shirt off the back of him who had one; if he had but his skin, of that he was flayed. It would be a mistake to suppose that it was only the captains of the écorcheurs-the bastards, the seigneurs without a seigneurie, who showed themselves so ferocious. The grandees, the princes in these hideous wars, had acquired a strange taste for blood. What can one say when one sees Jean de Ligny, of the house of Luxembourg, exercise his nephew, the Count of Saint-Pol, a child of fifteen, in massacring those who fled? They treated their kinsfolk in the same manner as their enemies. For safetybetter be a foe than a relation. The Count d'Harcourt kept his father prisoner all his life. 'The Countess of Foix poisoned her sister; the Sire de Gial his wife. The Duke of Brittany made his brother die of starvation, and that publicly; passers-by heard with a shudder the lamentable voice pleading piteously for a little bread. One evening, the 10th of January, the Count Adolphus of Gueldres dragged his old father out of bed, drew him on foot, unshod, through the snow for five leagues to cast him finally into a moat. It was the same in all the great families of the period-in those of the Low Countries, in those of Bar, Verdun, Armagnac, \&c. The English had gone, but France was exterminating herself. The terrible miseries of the time find expression, feeble as yet, in the 'Complaint of the poor Commoner ; and of the poor Labourers.' It comprises 


\section{SOUTERRAINS}

a mixtare of lamentations and threats; the starving wretches warn the Church, the King, the Burgesses, the Merchants, the Seigneurs above all, that "fire is drawing nigh to their hostels.' They appeal to the king for help. But what could Charles VII. do? How impose respect and obedience on so many daring men? Where could he find the means to repress these flayers of the country, these terrible little kings of castles? 'They were his own captains. It was with their aid that he made war against the English." 1

Thus, the subterranean refuges that had served at one time as hiding-places against Saracens, Normans, English, became places of retreat for the wretched people against their own masters. They no longer carried their goods into the souterrains under the castles, but into refuges contrived by themselves in the depths of forests, known only to themselves; hidden, above all, from their seigneurs.

The peasantry might have said then, what was said long after by Voltaire: "Il faut être dans ce monde enclume ou marteau; j'étais né enclume." Voltaire, however, speedily became a hammer, and after 1789 the Tiers État also became a hammer, and the Noblesse the anvil.

In Iceland there were underground retreats, as we learn from the same Saga that tells us of those in Aquitaine. Orvar Odd found a king's daughter concealed in one. So, also, a very large one in Ireland is spoken of in the Landnama Bok. In England we have, both in Essex and in Kent, subterranean passages and chambers very similar to those described in Picardy and in Aquitaine. These also are excavated in the chalk. They are the so-called Dene Holes, of which there are many in Darenth Wood and near Chislehurst, and they have given occasion to a lively controversy. Some have supposed them to be retreats of the Druids, some that they were places of refuge during the invasions of the Saxons first, and then of the Danes, and others again con-

1 Hist. de France, v. p. 184 et seq.

95 
tend that they were merely quarrics for the excavation of chalk to burn into lime.

Here is an account of the Dene Hole at Chislehurst by Mr. W. J. Nichols." "At the foot of the hill is a gap, which is the present entrance to the caves. A guide meets us here, who, unlocking a door, and switching on the electric light, introduces the visitor to a gallery or tunnel, about 150 feet long, 10 feet to 12 feet high, and with a width of 12 feet to 15 feet, narrowing to about 7 feet at the roof. 'This, and the galleries so far explored, have been cut through the chalk bed, at a depth of about 6 feet below the Thanet sand which covers it. At the end of the gallery, extending both right and left, are passages of like character. These again open into others so numerous that the visitor is fairly bewildered, and loses all idea of the direction in which he is travelling. The effect of the coloured electric lamps on the old chalk walling is remarkably beautiful. Proceeding on our way we get beyond the range of the electric lamps. Here candles or hand-lamps are lighted; and we pass, in Cimmerian gloom, through a succession of galleries of various dimensions, some of which, being only 4 feet wide and 5 feet high, are possibly of earlier construction than those already described. There is one gallery of the lastmentioned height and width 63 feet long, with several sharp turns which formerly terminated in a chamber about 12 feet high and 10 feet wide, and a like length, and near it is a seat cut into an angle of the walling. At no great distance from this chamber and near a Dene-hole shaft is a short gallery, at the end of which is a shaft originally level with the flooring, but now bricked round and further protected by an iron cover. On removing the cover and lowering a lamp, a well of excellent workmanship is discovered. Owing to the quantity of material thrown down from time to time

${ }^{1}$ Nichols (W. J.), "The Chislehurst Caves," Journal of the Archæological Association," Dec. 1903. 


\section{SOUTERRAINS}

by explorers, its present depth is no more than 43 feet. Further progress is made, and presently we notice a streak of daylight some distance ahead; here we find that we have reached the foot of a shaft 85 feet deep, which, though now partly covered in, had its mouth in what is at the present time the garden of a modern villa."'

There are numerous other Dene Holes or Danes' Pits at East Tilbury, Crayford, and Little Thurrock. As to the theory that they were places of Druidical worship, we may dismiss it as not deserving serious consideration.

At East Tilbury the entrance to the Danes' pit is from above, by narrow passages that widen and communicate with several apartments, all of regular forms. One of these pits consists of a shaft descending to chambers arranged like a sixfoiled flower. The shaft is 3 feet in diameter and 85 feet deep. 'This may be likened to one at Douéla-Fontaine (Maine et Loire), where a descent is made under a private house into an area from which radiate on all sides chambers, some of which contain tombs.

That these Dene Holes were used as hiding-places when the sails of the Danish Vikings appeared on the horizon is probable enough, but originally they were chalk quarries - some very ancient-for British coins have been found in them. The existence of old lime-kilns near the Chislehurst caves places their origin beyond a doubt. Chalk was largely exported in early times from the Thames to Zealand, whence it was passed through the Low Countries and used in dressing the fields. Altars to Nethalennia, the patroness of the chalk quarries, have been found in the sand on the coast of Zealand; some bear votive inscriptions from dealers in British chalk, and Pliny, writing of the finer quality of chalk (argentaria) employed by silversmiths, obtained from pits sunk like wells, with narrow mouths, to the depth of a hundred feet, whence they branch 


\section{SOU'IERRAINS}

out like the adits of mines, adds, "Hoc maxime Britannia utitur." I

In Cornwall, moreover, there are what are locally called fogous. These are either excavated in the rock with passages leading to the sea or to houses, or else they are built of stone slabs standing erect, parallel and covered with other slabs leading to chambers similarly constructed, and all buried under turf or sand. Of the former description there is a very interesting example at Porthcothan in S. Ervan; of the latter the most remarkable is at Trelowaren. The former may have been excavated by smugglers. An interesting account of the excavation of two caves at Archerfield, in Haddingtonshire, is given in the Proceedings of the Society of Antiquaries of Scotland for 1909. Both caves are natural, but one had been walled up in front, with a doorway and window and with oven; both had paved hearths in the centre, and there was evidence that they had been tenanted some time after the Roman occupation of Britain, as among the fragments of pottery found was some Samian ware. It would appear that both had been inhabited simultaneously, but not consecutively, for a lengthy period, and no doubt can exist that they were mere rock refuges. In a note to the article we read: "On the coast of Island Magee (Ireland) there is a cave, south of the Gobbins, which has been frequently used as a place of refuge. So late as 1798 it was inhabited by outlaws, who constructed a kind of fortification at the entrance, the remains of which still exist." 2

A cave in the Isle of Egg, one of the Hebrides, has a very narrow entrance, through which one can creep only upon hands and knees, but it rises steeply within and soon becomes lofty, and runs into the bowels of the rock for

1 Roach Smith, Collectanea Antiqua, vi. p. 243, "British Archæological Assoc. Journal," N.S., ix.-x. (1903 and 1904).

\& Cree (J. R.), "Excavation of Two Caves," in "Proceedings of the Soc. of Arch. of Scotland," Edin., 1909, vol. xliii. 


\section{SOUTERRAINS}

225 feet. 'The stony, pebbly bottom of this cavern was for long strewn with the bones of men, women and children, the relics of the ancient inhabitants of the island, two hundred in number, of whose destruction the following account is given. "The Macdonalds, of the Isle of $\mathrm{Egg}$, a people dependent on Clanranald, had done some injury to the Lord of Macleod. The tradition of the isle says that it was by a personal attack on the chieftain, in which his back was broken; but that of the two other isles bears that the injury was offered by two or three of the Macleods, who, landing upon Egg and behaving insolently towards the islanders, were bound hand and foot, and turned adrift in a boat, which the winds safely conducted to Skye. To arenge the offence given, Macleod sailed with such a body of men as rendered resistance hopeless. The natives, fearing his vengeance, concealed themselves in the cavern; and, after strict search, the Macleods went on board their galleys after doing what mischief they could, concluding the inhabitants had left the isle. But next morning they espied from their vessels a man upon the island, and immediately landing again, they traced his retreat by means of a light snow on the ground to the cavern. Macleod then summoned the subterranean garrison, and demanded that the inhabitants who had offended him should be delivered up. This was peremptorily refused. The chieftain thereupon caused his people to dirert the course of a rill of water, which, falling over the mouth of the cave, would have prevented his purposed vengeance. He then kindled at the entrance of the cavern a large fire, and maintained it until all within were destroyed by suffocation." 1

A no less horrible deed was committed during the campaign of Essex against the Irish rebels in 1575. This shall be given in the words of Froude.?

1 Lockhart's "Life of Sir Walter Scott," Edin., 1944, p. 285.

" "Hist. of England," 1s70, x. p. 527 et seq. 


\section{SOU'LERRAINS}

"On the coast of Antrim, not far from the Giant's Causeway, lies the singular island of Rathlin. It is formed of basaltic rock, encircled with precipices, and is accessible only at a single spot. It contains an area of about 4000 acres, of which a thousand are sheltered and capable of cultivation, the rest being heather and rock. The approach is at all times dangerous; the tide sets fiercely through the strait which divides the island from the mainland, and when the wind is from the west, the Atlantic swell renders it impossible to land. The situation and the difficulty of access had thus long marked Rathlin as a place of refuge for Scotch or Irish fugitives, and besides its natural strength it was respected as a sanctuary, having been the abode at one time of Saint Columba. A mass of broken masonry on a cliff overhanging the sea is a remnant of the castle, in which Robert Bruce watched the leap of the legendary spider. To this island, when Essex entered Antrim, Macconnell and the other Scots had sent their wives and children, their aged, and their sick, for safety. On his way through Carrickfergus, when returning from Dublin, the Earl ascertained that they had not yet been brought back to their homes. The officer in command of the English garrison was John Norris, Lord Norris's second son. 'Three small frigates were in the harbour. The sea was smooth; there was a light and favourable air from the east; and Essex directed Norris to take a company of soldiers with him, cross over, and kill whatever he could find. The run up the Antrim coast was rapidly and quietly accomplished. Before an alarm could be given the English had landed, close to the ruins of the church that bears Saint Columba's name. Bruce's castle was then standing, and was occupied by a detachment of Scots, who were in charge of the women. But Norris had brought cannon with him. 'The weak defences were speedily destroyed, and after a fierce assault, in which several of the garrison were killed, the chief who 


\section{SOUTERRAINS}

was in command offered to surrender if he and his people were allowed to return to Scotland. The conditions were rejected; the Scots yielded at discretion, and every living creature in the place, except the chief and his family, who were probably reserved for ransom, were immediately put to the sword. Two hundred were killed in the castle. It was then discovered that several hundred more, chiefly mothers and their little ones, were hidden in the caves about the shore. There was no remorse-not even the faintest perception that the occasion called for it. They were hunted out as if they had been seals or otters, and all destroyed. Surleyboy and the other chiefs, Essex coolly wrote, 'stood upon the mainland of Glynnes and saw the taking of the island, and was likely to have run mad for sorrow, tearing and tormenting himself, and saying that he had there lost all that ever he had.' According to Essex's own account, six hundred were thus massacred. $\mathrm{He}$ described the incident as one of the exploits with which he was most satisfied; and Queen Elizabeth in answer to his letters bade him tell John Norris, "the executioner of his well-designed enterprise, that she would not be unmindful of his services." 'The neighbourhood of Gortyna in Crete has a mountain labyrinth, and during the revolt of the Cretans against the Turks in 1822-28, the Christian inhabitants of the adjacent villages, for months together, lived in these caves, sallying forth by day to till their farms or gather in their crops, when it was safe so to do. None could approach within range of the muskets pointed from the loopholes at the entrance without being immediately shot down; nor could either fire or smoke suffocate or dislodge the inmates, as the caves have many openings.

Less happy were the Christian refugees in the care of Melidoni. In 1822, when Hussein Bey marched against the neighbouring village, the inhabitants, to the number of three hundred, fled to the cave, taking their valuables 


\section{SOUTERRAINS}

with them. Hussein ordered a quantity of combustibles to be piled at the entrance and set on fire. 'The poor' wretches within were all smothered. The Turks waited a few days, and then entered and rifled the bodies. A week later, three natives of the village crept into the cavern to see what had become of their relatives. It is said that they were so overcome by the horror of what they witnessed, that two of them died within a few days. Years after, the Archbishop of Crete blessed the cavern, and the bones of the victims of Turkish barbarity were collected and buried in the outer hall, which has in its centre a lofty stalagmite reaching to the summit, and the walls on all sides are draped with stalactites.

We must not pass over without a word the treatment of the Arabs in Algeria by the French troops, when General Lamorcière suffocated the unfortunate refugees in the caves whither they had fled, in the same way as Casar's general had suffocated the Gauls. 


\section{CHAP'TER IV}

\section{CLIFF REFUGES}

T HAVE divided Refuges into two classes-those that have been burrowed under the soil, and those that open in the face of a cliff. Occasionally they run one into another, and yet they materially differ. The first have their entrances elaborately concealed, whereas the latter are bare to the face of day, and no concealment is possible or attempted. Those who had recourse to the first trusted in being able, should the entrance be discovered or betrayed, to defend themselves by various devices, whereas those who resorted to the latter relied on their inaccessibility.

Where a cliff stood up precipitous or overhanging, and in its face gaped caverns, those who sought refuge in time of danger naturally looked to them, and contrived means of reaching them, therein to ensconce their goods and secure their persons. They might have to contemplate the devastation of their fields, and their farms burning, from their eyries, but they knew that their persons were safe. There were various ways by which these caves could be reached; one was by cutting notches in the face of the cliff for fingers and toes, so that it could be climbed to from below, but not accessible to an enemy exposed to the thrust of pikes, and to stones being cast down upon him. Or else the notches were cut laterally from an accessible ledge, but if so, then this mode of approach was carefully guarded. A second method was by ladders, but as some of these caves are so high up that no single ladder could reach their mouths, a succession was contrived notched below and above into 103 


\section{CLIFF REFUGES}

the rock where ledges either existed naturally or were contrived artificially, so as to enable the climber to step from one ladder to the next. In the event of danger the ladders could be withdrawn. A third method was by a windlass, rope and basket, and this was employed where the ascent by finger and toe notches was peculiarly perilous, for the conveyance of goods or of children and old people. But cattle had also to be saved from the depredators, and in some of the cliff refuges are stables for horses and cowstalls, with mangers and silos; places also where the windlass was fixed and there the sharp edge of the rock has been smoothed to an easy slope to facilitate the landing of the beasts, that were hauled up by bands placed under their bellies. Provision was also made for the baking of bread and the storage of water, this latter in the same way as already described in the account of the contrivances for permanent rock-dwellings. 'These cliff refuges can have been had recourse to only on emergencies, on account of their inaccessibility.

At Cazelles in the commune of Sireuil (1)ordogne) is a cliff 1200 feet long, and about 150 feet high. It has been worn into a deep furrow some twenty or thirty feet from the top, horizontal and running its entire length. The whole cliff' overhangs its base. The entire groove has been occupied as a refuge, and there have been excavations in the back of the groove for additional chambers. In front, moreover, there must have been a balcony of wood, sustained by beams and props. In three places the edge of the terrace has been cut through for the convenience of hauling up cattle and farm produce. At the time when this was in use there was a hamlet at the foot of the cliff, as is shown by the furrows cut in the rock into which the tile roofing was let, and notches for the reception of the roof timbers.

No trace of a stair remains; in fact no stair could have been cut in the face of a rock that overhangs as does this. 



\section{CLIFF REFUGES}

Another very remarkable cliff-refuge is Le Peuch Saint Sour on the Vézère. It is not mentioned in any chronicle as having been a resort of the English in the Hundred Yeprs' War, and we may accordingly conclude that it was a refuge for the inhabitants of the hamlet at its feet.

S. Sorus or Sour was a hermit, born about the year 500 ; he set off with two companions, Amandus and Cyprian, to find a desert place where he might take up his abode. I will quote from the Latin life. "All at once in their wanderings they arrived at a place in the midst of vast forests, and dens of wild beasts, a place so barren and abrupt, of access so difficult, that surely no one had ever hitherto ventured to reach it either to dwell there, or for pleasure, even to visit it for curiosity. A rock very lofty furnished him above with a shelter that sufficed; out of the flanks of the rock issued a spring and watered the little valley that was on the other side surrounded by the Yézère."

I think that it was in the Peuch S. Sour that the hermit settled, though afterwards through the farour of King Gontram he moved to lands granted him at 'Terrasson. And now for a story. Here he resolved to live alone, and here he parted with his companions. But before they separated, "Let us have a love feast together," said he. But he had with him only a bit of fat bacon. He divided it into three parts, and gave a share to each of his companions. Now it was Lent, and one of them was scandalized at the idea of eating bacon in Lent, so he put the bit of meat into his bosom, where it was at once transformed into a serpent, which enwrapped him in its coils. Terrified, he screamed to Sour to deliver him, which the hermit did, and the monster was at once resolved into a bit of bacon. "Eat it," said the hermit, "and remember that Charity is above all rules."

The description of the place so well accords with the Peuch that bears his name, that I cannot doubt but that 


\section{CLIFF REFUGES}

Sour occupied for some years the cave high up in the cliff, and only to be reached by crawling to it sideways, holding on to the rock by fingers and toes. But afterwards it was greatly enlarged to serve as a place of retreat by the peasants of the hamlet below. It consists of three groups of chambers cut in the rock, one reached by a very long, forty-round ladder, when a chamber is entered which has a hole in the roof through which, by another ladder, one can mount to a whole series of chambers communicating one with another. The face of some of these was originally walled up. A second group is now inaccessible. A third is reached by

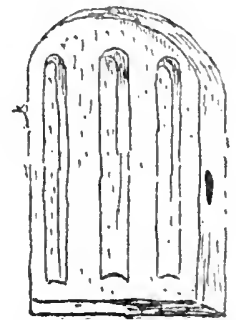

Beginning of a Gallery.

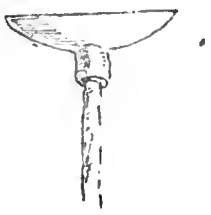

The Pick employed.

climbing along the face of the cliff, with fingers and toes placed in niches cut in the cleft to receive them.

A recess at the foot of the crag, arched above, contains three perpendicular grooves. This was the beginning of another artificial cave, never completed, begun maybe in 1453 and suddenly abandoned, as the glad tidings rang through the land that the English had abandoned Aquitaine and that the Companies were disbanded.

At the Roc d'Aucor, in the valley of the Vers (Lot), a gaping cave is visible far above where any ladder could reach and inaccessible by climbing from the top of the crag, as that overhangs like a wave about to break. Nevertheless, athwart the opening are, and have been from time immemorial, two stout beams let into the rock horizontally. 106 


\section{CLIFF REFUGES}

Dimly visible in the depth of the cavern is some tall white figure, and the peasants declare that it is that of a man-a statue in marble, keeping guard over a golden calf.

In 1894, M. Martel and three friends, taking with them Armand, the trusty help in descending avens, pot-holes, and exploring the course of subterranean rivers, resolved on an attempt at the exploration of this mysterious cavern.

The mouth is 90 feet from the ground, and its floor is about 95 feet from the summit of the cliff, 1 which is crowned by the oppidurn of Murcens, the best preserved of all Gaulish strongholds in France, and was held by the English in 1370. The only possible way to obtain access to the interior would be from above, as the plumb-line let down from the summit fell 44 feet wide from the base of the cliff. Accordingly a rope ladder was attached to a tree on the top, and Armand descended furnished with a plumbline, the end of which was attached to a cord. "Having descended $7 \gamma$ feet, he swung free in the air at the level of the transverse poles. Then he endeavoured to throw the lead-weight beyond one of the poles. He succeeded only after the seventh or eighth attempt, and was well pleased when the weight running over it swung down to our feet, as the position of the poles and the slope of the floor of the fissure did not allow it to rest in the cavern. 'Pull the cord,' shouted Armand. 'What for?' 'You will soon see. Pull' - and speedily the string drew after it one of our stout ropes. 'Now do you understand?' asked Armand. 'I have fastened my rope ladder to the cord that goes over the pole. Four or five of you pull and draw me in towards that pole, and so we shall get the better of the situation. When I have fixed the ladder to the pole you may all mount by the grand stair.',

By good fortune that beam held firm, and first Armand got into the cave and then the others mounted from below.

1 Martel (A.), Le Réfuge du Roc d'Aucor, Brive, 1895. 


\section{CLIFF REFUGES}

What made the entrance treacherous was that the floor at the orifice sloped rapidly downwards and outwards.

When within, it was seen that the posts were still solid and firmly planted in notches cut in the rock on both sides. In line with them were two rows of similar notches for the reception of beams extending inwards for about twenty feet, as though at one time there had been rafters to divide the cave into two storeys, but of such rafters none remained. The back of the cave was occupied by a gleaming white stalagmitic column that certainly from below bore some resemblance to a human figure, but the floor of the cavern was so deep in birds' nests, and droppings of bats, leaves and branches, that it was not possible at the time to explore it. 'This, however, was done by M. Martel in 1905, but nothing of archæological interest was found. However, he noticed a sort of ascending chimney that extended too far to be illumined to its extremity by the magnesium wire, and he conjectured that it extended to the surface of the rock above, where was the original entrance, now choked with earth and stone.

But an investigation by M. A. Viré has solved the mystery of how access was obtained to this refuge. The beams visible from below are, as already said, two in number. The upper and largest is square, and measures seven by eight inches. 'The lower is nearly round and is four inches in diameter, and shows distinct traces of having been fretted by a rope having passed over it. It must have been used for the drawing up of food or other objects likely to excite the cupidity of robbers and routiers. The number of notches for beans of a floor in the sides of the cave is remarkable, but no floor can have been erected there, otherwise it would not have rotted away, whilst the two cross-beams at the entrance remain sound. The chimney supposed by Martel to communicate with the surface does not do so. Spade work at the foot of the rock revealed the manner in which 


\section{CLIFF REFUGES}

the cavern had been reached. A tradition existed in the Vers valley that at one time there had been a tower at the foot of the rock, and old men remembered the removal of some of its ruins for the construction of a mill. By digging, the foundations of the tower were disclosed. It had been square and measured 44 feet on each side. It had stood about 60 feet high, and had been topped with a lean-to tiled roof resting against the uppermost beam in the cave and thereby masking it. ${ }^{1}$

A somewhat similar cave is that of Boundoulaou in the Causse de Larzac (Lozère). Although this has an opening in the face of the precipice, which is partly walled up, it can be entered from another and more accessible cave. At a considerably lower level flows a stream that at one time issued from it, but has worked its way downwards, and now gushes forth many feet below. However, apparently in times of heavy rain, the orerflow did burst forth from the upper carern, for in it were found the skeletons of a whole family that had perished on one such occasion.

At nearly 180 feet up the face of a sheer perpendicular cliff near Milau is the cave of Riou Ferrand, 45 feet below the brow of the precipice. The mouth of the grotto is partly blocked by a well-constructed wall. It has been entered from above and explored. It yields delicately fine pottery and a spindle-whorl, so that a woman must have taken refuge here, and here sat spinning and looking down from this dizzy height on the ruffians ravaging the valley below and setting fire to her house. Bones of sheep and pigs in the cave showed that it had been tenanted for some time, and tiles of distinctly Roman character indicated the period of its occupation. The only possible means of entering this cavern is, and was, by a rope or a ladder from above. ${ }^{2}$

1 "Le Roc d'Aucour," in Bulletin de la Soc. des Antiquaires de Quercy, Cahors, 1901, t. xxri.

2 Martel, Les Abines, Paris, 1894. 


\section{CLIFF REFUGES}

I was in the valley of the Célé in 1892 with my friend M. Raymond Pons, a daring explorer of avens and caves. There was one cavern in a precipice on the left bank near Brengues that showed tokens of having been a refuge, from having a pole across the entrance. M. Pons obtained a stout rope, and the assistance of half-a-dozen peasants, and was let down over the brink, and by swinging succeeded in obtaining a foothold within. He there found evident traces of former occupation. But how was it entered and left in ancient times? From below it was quite inaccessible, and from above only by the means he employed-a rope.

At Les Mées in the Basses-Alpes is a very similar cave, with two beams across fastened at the ends into the rock, which is a conglomerate, at the height of 350 feet, and quite inaccessible. They are mentioned by the historian Bartel in 1636 as inexplicable by him, and by the residents in the place.

A not less perplexing rock shelter is that of Fadarelles in the Gorges of the Tarn.

Of this M. Martel writes: "In a superb cliff of dolomitic limestone of the cirque of the Beaumes Chauds, M. l'Abbé Solanet was good enough to conduct me beneath the Baume des Fadarelles, a chasm inaccessible, at the height of something like $17 \% 0$ feet in the face of the precipice, something like the openings of Boundoulaou, but much narrower.

"In it one can see three coarse beams or rather trunks of trees from which the boughs have been cut away, each about 12 feet long. As this opening might well have been that of discharge of a stream, now choked, for the Baumes Chauds and its adjoining fissures, one is led at first to suppose that water had brought down these logs that had fallen into some pot-hole. But this hypothesis is untenable, for it can be seen that these poles have been artificially pointed at each end, and that they have been made firm by 


\section{CLIFF REFUGES}

cross pieces of metal, either bronze or iron. This may be the remains of a roof or a floor destined to supplement the insufficiency of the overhanging rock-and of the size of the fissure, so as to convert it into some sort of shelter. To study the matter, a ladder of nearly 50 feet would be needed (to be let down from above). In the absence of all tradition, these beams of Les Fadarelles remain a mystery. As the face of the cliff is absolutely smooth above the opening, below and on both sides, completely devoid of anything like a ledge by which access could be obtained to it, the question presents itself to one for the third time, as at Boundoulaou and at Riou Ferrand, were these cliff$\mathrm{d}$ wellers in the Causses like those in the Cañon of Colorado, or has the demolition of ledges by weather on these limestone cliffs proceeded with great rapidity?"

Two apparently inaccessible caves, that have been the habitation of man as a temporary lefuge, and that have been explored by M. Philibert Lalande, show that there was a way in which some, though by no means all, were reached. The grottoes of Puy Labrousse near Brive, comprising five or six chambers, have isolated from the rest one that opens in the face of a sheer precipice at a considerable height above the valley. It can be entered only from behind, by a very small oval opening, preceded by a gallery very narrow, and masked at the entrance by enormous rocks, and which could be barricaded by stout beams, hollows for the reception of which are visible.

The other is at Soulier-de-Chasteaux on the Couze, an affluent of the Vézère. Here are two caverns excavated by the hand of man. The most curious is on the right bank near the top of a Jurassic cliff that is absolutely precipitous, and this also can be entered a retro. A narrow path leads to an opening very small, excavated in the vault of the cavern, through which a man could squeeze himself so as to descend into it by means of a ladder. The gaping mouth 


\section{CLIFF REFUGES}

of this grotto, which is from 15 to 18 feet square, is in part closed by a breastwork of stone.

Below this cave is a very large shelter cut out squareheaded in the cliff, but not deep; and this is used by the peasants of Soulier as a place for stacking their hay. Square hollows wrought in the rock show that formerly some building was accommodated to it, and the roof ran back under it. In Auvergne are many souterrains that have served as places of concealment in times of war. The Puy de Clierson occupies the centre of an area of four volcanoes. It is shaped like a bell, the slopes are covered with brushwood, and a ring of broken rocks forms the precipitous wall of the circular and flattish cap. The hill is composed of trachyte, and the upper portion is perforated in all directions by galleries and vaults that served formerly as a quarry for the extraction of stone of which the Romans formed their sarcophagi, in consequence of its powers of absorption of the moisture exuding from the bodies laid in their' stone chests. 'The same may be said of Le Grand Sarcoui, shaped like a kettle turned bottom upwards. In some of the galleries are unfinished sarcophagi. But although originally quarries, they were used as refuges in later times. At Corent, on the Allier near Veyre-Mouton, are refuges in caves, so also at Blot-l'Eglise near Menat, which served the purpose during the troubles of the League.

Meschers is a village in Charante Inférieure, lying in the lap of a chalk hill that extends to a bluff above the Gironde. This cliff is honeycombed with caves, excavated perhaps originally as quarries, but several certainly served as habitations; the several chambers or dwellings are reached by a ledge running along the face of the cliff, but the chambers of each particular cave-house have doors of intercommunication cut through this rock. The Grottes de Meschers are said to have been used by the Huguenots at a time when it was perilous to assemble in a house for 

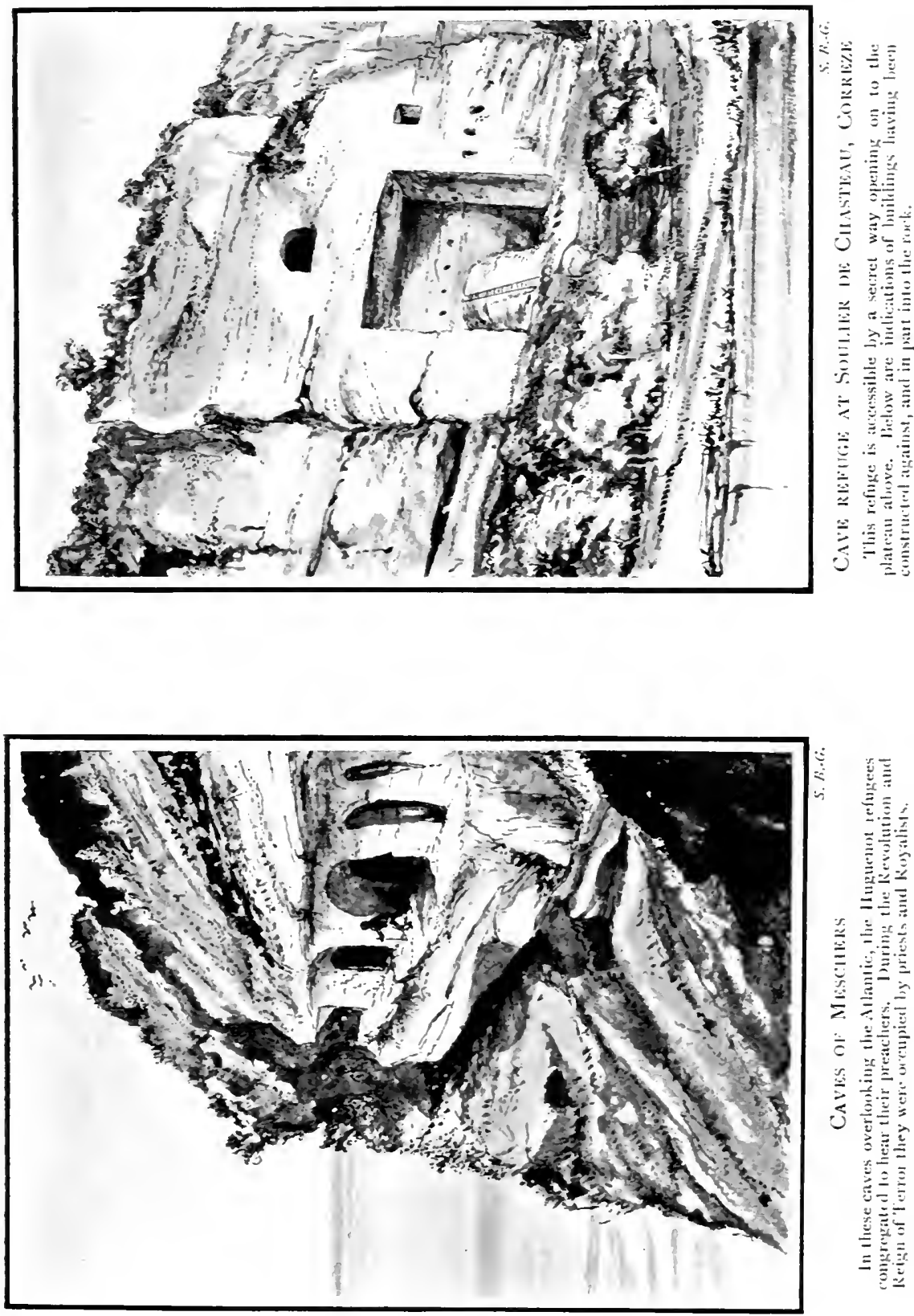


\section{CLIFF REFUGES}

preaching or psalm-singing. But it is also quite possible that they served as refuges as well to the Catholics, when the Calvinists had the upper hand; as, indeed, they had for long. Their attempts at proselytising was not with velvet gloves, but with fire-brand, sword, and the hangman's rope. In that horrible period, exceeding far in barbarity that of the routiers in the Hundred Years' War, it is hard to decide on which side the worst atrocities were committed.

Later still, in the Reign of Terror, the grottoes may have harboured priests and nobles hiding for their lives. But now they shelter none but the peaceful dreamer, who sits there at eventide looking out over the yellow waters of the Gironde, ever agitated by the tide, at the setting sun that sends shafts of fire into these recesses-and sets him wishing that the light would reveal the details of tragic stories connected with these caves.

In the department of Ariège are a vast number of natural caverns, many of which have served as places of retreat for the Albigenses. Between Tarascon and Cabannes are some that were defended by crenellated walls, and are supposed to date from the Wars of Religion, but probably go back beyond the time of the English occupation. It is also said that the Huguenots met in them for their assemblies. In the country they go by the name of gleizetos, or petites eglises. They are found on the left bank of the Ariège. In the fourth century the Priscillianist heretics expelled from Spain settled in the mountains on the north slope of the Pyrenees, and propagated their doctrines throughout the country and among the population more than half pagan, and this explains the spread of Albigensian Manichæism later. In 407 the Vandals, Suevi and Alani, during three years in succession swept the country, committing frightful ravages, as they passed on their way into Spain; and no doubt can be entertained that at this 


\section{CLIFF REFUGES}

time the numerous grottoes were used by the natives as refuges. In 412 there was another influx of barbarians, this time Visigoths; their king Walla made Toulouse his capital, and gave over two-thirds of the land to his followers. After the battle of Voulon, in 507, Clovis took possession of Toulouse. In 715 the Saracens poured through the gaps in the Pyrenees, occupied the basin of the Ariège, and destroyed the city of Couserans. In 731 more arrived in a veritable invasion of multitudes, and ravaged all the south of France. Again the caves served their end as places of hiding. The south of France, rich and dissolute, was steeped in heresy. 'This heresy was a compound of Priscillianism, the dualism of Manes, Oriental and Gnostic fancies, Gothic Arianism, and indigenous superstition, all fused together in what was known as Albigensianism, and which was hardly Christian even in name. The terrible and remorseless extermination of these unfortunate people, who knew no better, by order of Innocent III. and John XXIII., presents one of the most horrible passages in history. The country reeked with the smoke of pyres at which the heretics were burnt, and was drenched with their blood. In 1244 their last stronghold, the Montsegur, was taken, when two hundred of them were burnt alive. Only some few who had concealed themselves in the dens and caves of the earth survived this terrible time. The last heard of them is in 1328, when some of the proscribed took refuge in the grottoes of Lombrive, when 500 or 600 were walled in and starved to death, as already related.

In Derbyshire are numerous caves-at Castleton, Bradwell Eyam, Matlock, and Buxton-but they are all natural, except such as are old mine-workings.

Poole's Hole, the Buxton cavern, may be traced underground for the distance of something like half a mile. It is now lighted with gas, its inner ways have been made smooth, and it is even possible for invalids in bath-chairs 


\section{CLIFF REFUGES}

to enter. But it was at one time the haunt of an outlaw named Poole, in the reign of Henry IV., who made it his home, and here accumulated his stores. But it was inhabited long before his time, and proves to have been a prehistoric dwelling-place, and was later occupied by the Romans.

Reynard's Cave is high up on the Derbyshire side of Dove Dale, and the way to it is steep and dangerous. It is approached through a natural archway in a sheer cliff of limestone, about 20 feet wide and twice as high, beyond which a difficult pathway gives access to the cave itself. Near it is a smaller cavity, called Reynard's Kitchen. This cavern has undoubtedly served as a shelter, it is said, to persecuted Royalists. Here it was that the Dean of Clogher, Mr. Langton, lost his life a century ago. He foolishly tried to ride his horse up the steep side of the Dale to the cave, and carry a young lady, Miss La Roche, behind him. The horse lost its foothold among the loose stones, and the rash equestrian fell. The Dean died two days afterwards, but the young lady recovered, saved by her hair having caught in the thorns of a bramble bush. High up, among the rocks on the Staffordshire side in a most secluded spot, is a cleft called Cotton's Cave, which extends something like 40 feet within the rock. Here it was that Charles Cotton, the careless, impecunious poet, the friend of Isaac Walton, was wont to conceal himself from his creditors. On the top of Lovers' Leap, a sheer precipice, is what was once a garden where the two anglers sat and smoked their pipes. Close by is an ancient watch-tower, from which was seen Cotton's wife's beacon-fire lit to announce to him that the coast was clear of duns, and to light him home in the black nights of winter.

'Thor's Cave is in a lofty rock on the Manifold River. The cliff rises to an altitude of four or five hundred feet, terminating in a bold and lofty peak; and the cave is situated about half-way up the face of the precipice. The cave is arched at the entrance, a black yawning mouth in 


\section{CLIFF REFUGES}

the white face of the limestone. It is a natural phenomenon, but appears to have been enlarged by cave-dwellers. It has been explored by a local antiquary, and has yielded evidence of having been inhabited from prehistoric times.

The name of Thor's Cavern carries us back to the time when the Norsemen occupied Deira and Derbyshire, and Jordas Cave in Yorkshire does the same-for the name signifies an Earth-Giant.

In the crevices of Bottor Rock in Hennock, Devon, John Cann, a Royalist, found refuge. He had made himself peculiarly obnoxious to the Roundheads at Bovey Tracey, and here he lay concealed, and provisions were secretly conveyed to him. Here also he hid his treasure. A path is pointed out, trodden by him at night as he paced to and fro. He was at last tracked by bloodhounds to his hidingplace, seized, carried to Exeter and hanged. His treasure has never been recovered, and his spirit still walks the rocks.

At Sheep's Tor, where is now the reservoir of the Plymouth waterworks, may be seen by the side of the sheet of water the ruins of the ancient mansion of the Elfords. The Tor of granite towers above the village. Among the rocks near the summit is a cave in which an old Squire Elford was concealed when the Parliamentary troopers were in search of him. Polwheel in his "Devon" mentions it. "Here, I am informed, Elford used to hide himself from the search of Cromwell's party, to whom he was obnoxious. Hence he could command the whole country, and having some talent for painting, he amused himself with that art on the walls of his cavern, which I have been told by an elderly gentleman who had visited the place was very fresh in his time." None of the paintings now remain on the sides of the rock.

The cave is formed by two slabs of granite resting against each other. It is only about 6 feet long, 4 wide, and 5 feet high, and is entered by a very narrow opening. 


\section{CHAP'TER V}

\section{CLIFF CASTLES. THE ROUTIERS}

$\mathrm{F}$ ROM a very early period in the Middle Ages-in fact from the dissolution of the Carlovingian dynastywe find communities everywhere grouped about a centre, and that centre the residence of the feudal chief to whom the members of the conmunity owed allegiance and paid certain dues, in exchange for which he undertook to protect his vassals from robbery and outrage. By the Edict of Mersen, in $84 \%$, every freeman was suffered to choose his own lord, whether the King or one of his vassals, and no vassal of the King was required to follow him in war, unless against a foreign enemy. Consequently the subjects were able to make merchandise of their obedience. In civil broils the King was disarmed, helpless; and as he was incapable of defending the weak against their oppressors, the feeble banded themselves under any lord who could assure them of protection. The sole token that the great nobles showed of vassalage to the Crown was that they dated their charters by the year of the Sovereign's reign.

As the security of the community depended on the security of the seigneur, it behored that his residence should be made inexpugnable. To this end, where possible, a projecting tongue of land or an isolated hill was selected and rendered secure by cutting through any neck that connected it with other high ground, or by carving the sides into precipices. Like a race of eagles, these lords dwelt on the top of the rocks, and their vassals crouched at their feet.

But although the dues paid to a seigneur were fixed by $11 \%$ 


\section{CLIFF CASTLES}

custom, it not infrequently happened that the receipts were inadequate to his wants. He had to maintain armed men to guard his castle and his tenants, and these armed men had to be paid and kept in good humour. The lord accordingly was disposed to increase the burdens laid on his serfs, and that to such an extent as to drive them into revolt. $\mathrm{He}$ on his part was not unaware of the fact that he held a wolf by the ears, and his impregnable position was chosen not solely as a defence against foreign enemies, but also against his rebellious vassals.

The village of Les Eyzies is dominated by the ruins of a castle of the tenth or eleventh century, that was restored in the fifteenth, when a graceful turret was added. The keep is planted on a precipitous rock, and rises to the overhanging roof of chalk that is pierced with rafter-holes for the reception of roof beams, and with openings only to be reached by ladders leading to caves that served as storehouses. At the junction of the Beune with the Vézère, a little further down is a rock standing by itself, shaped like a gigantic fungus. This is called the Roche de la Peine, as from the top of it the Sieur de Beynac, who was also lord of Les Eyzies, precipitated malefactors. But under that designation he was disposed to reckon all such as in any way offended him. In 1594 the Sieur, to punish two of his peasant vassals who had committed a trifling offence, killed one, and dragged the other over stones, attached to the tail of his horse. 'This act of barbarity roused public indignation, and a deputation waited on the seneschal of Perigord to demand retribution. But having received no satisfaction from this officer, in 1595, the peasants took the matter into their own hands, revolted and besieged the castle. As they failed to take it, they turned on the property of the seigneur, tore up his vines, cut down his woods, and burnt his granges.

The incessant wars that swept France, its dismemberment 118 


\section{CLIFF CASTLES}

into duchies and counties and seigneuries, practically independent, and above all the English domination in Guyenne for three hundred years, enabled the petty nobles to shake off the very semblance of submission to their liege lords, and to prosecute their private feuds without hindrance. After Poitiers, 1356, and the captivity of King John, anarchy reigned in the land; bands of plunderers ranged to and fro, threatening persons and ravaging lands; and the magistrates could not, or would not, exercise their authority. Local quarrels among rival landowners, the turbulent and brutal passions of the castle-holders, filled the land with violence and spread universal misery, from which there seemed to be no escape, as against the wrongdoers there was no redress. After the Treaty of Bretigny in 1360, Aquitaine ceased to be a French fief, and was exalted in the interests of the King of England into an independent sovereignty, together with the provinces of Poitou, the Saintonge, Aunis, Agenois, Perigord, Limousin, Quercy, Bigorre, Angcumois and Rouergue, greatly to the dissatisfaction of the people, who remonstrated against being handed over to a foreign lord. Charles V. and Charles VII. sought on every available occasion to escape from its obligations, and the towns were in periodic revolt. William de Nangis says of the condition of the country under Charles V.: "There was not in Anjou, in 'Touraine, in Beauce, in Orleans, and up to the very approaches of Paris, any corner of the country that was free from plunderers. They were so numerous everywhere, either in little castles occupied by them, or in villages and the countryside, that peasants and tradesmen could not travel except at great expense and in mighty peril. 'The very guards told off to protect the cultivators of the soil and the travellers on the highways, nost shamefully took part in harassing and despoiling them. It was the same in Burgundy and the neighbouring countries. Some knights who called themselves friends of the King, whose names I 


\section{CLIFF CASTLES}

am not minded to set down here, kept brigands in their service, who were every whit as bad. What is more strange is that, when these ruffians went into the cities, Paris, or anywhere else, everybody knew them and pointed them out, but none durst lay hands on them."

The condition of Germany was but little superior to that of France. 'The central authority, if that can be called central which was always shifting its position, was unequal to restrain the violent. Its pretensions were in inverse proportion to its efficiency. 'The Emperor was too far off to see to the policing of the Empire, too weak to enforce order; and his long absences in Italy left the German lords and lordlings to pursue their own courses unrestrained. When the Emperor Frederick Barbarossa visited the Baron van Kingen in his castle near Constance, the freiherr received him seated, because, as he said, he held his lands in fee of none but the sun. Although he was willing to receive the Emperor as a guest, he refused to acknowledge him as his lord. If this was the temper of the petty nobility in a green tree, what must it have been in the dry. After that the great houses of Saxony and Swabia had been crushed out by the policy of the Papacy, it was to the interest of the electors to keep the Emperor weak; and the fact that the Imperial Crown was elective enabled the electors to sell their votes for extended privileges. At last, against the raids of the petty nobles, whom the Emperor could not control, the cities leagued together, took the matter in hand, attacked the fortresses, levelled them and gave to the inmates short shrift, a halter and a tree. In Italy the towns proceeded in a less summary manner. Surrounded as they were on all sides by a serried rank of castles, where the nobles held undisputed sway over their serfs and controlled the arteries of trade, the cities were compelled to proceed against them; but instead of sending them to the gallows, they contented 


\section{CLIFF CASTLES}

themselves with forcing them to take up their residence within the town walls. But though the feudal lordship of these nobles had been destroyed, their opulence, their lands, the prestige of their names remained untouched, and in place of disturbing the roads they filled the streets with riot. They reared in the towns those wonderful towers that we still see at Bologna, San Gemigniano, Savona, \&c. "From the eighth to the thirteenth century," says Ruskin, "there was little change in the form;-foursquare, rising high and without tapering into the air, storey above storey, they stood like giants beside the piles of the basilicas and the Lombardic churches ... their ruins still frown along the crests of every promontory of the Apeninnes, and are seen from far away in the great Lombard plain, from distances of half a day's journey, dark against the amber sky of the horizon." 1

I propose dividing my subject of cliff castles into four heads :-

1. Those that were seigneural strongholds.

2. Those that with castle and town occupied a rock.

3. The fastnesses of the routiers, the Companies in the Hundred Years' War.

4. Outpost stations guarding fords, roads into a town, and passes into a country.

And I shall begin with No. 3-The Castles of the routiers.

The face of a country is like that of a woman. It tells the story of its past. The many-windowed English mansion sleeping among turfy lawus to the plash of a fountain, and the cawing of rooks in the beechwood, tell of a tranquil past life-record broken only by transient unrest; whereas the towers on the Continent with their meurtrières and frowning machicolations, bristling on every hill, frequent as church spires, now gutted and ruinous, proclaim a

\section{Lectures on Architecture, 1853.}




\section{CLIFF CASTLES}

protracted reign of oppression and then a sudden upheaval in resentment and a firebrand applied to them all. The old English mansion has its cellars, but never an oubliette, its porch-door always open to welcome a neighbour and to relieve the indigent. It was not insulated by a dyke, and its doors clenched with a portcullis. 'Ihe spoils of the chase were not a drove of "lifted" cattle taken from a peasant left stark upon his threshold, but foxes' masks and the antlers of deer. The pigeons coo about the English gables and the peacock dreams in the sun on the balustrade of the terrace, as in past centuries, but the castle of the French noble and the burg of the German ritter are given over to the bats and owls, and are quarries whence the peasants pick out the heraldic carvings for the construction of their pig-styes.

Nowhere did tears so stain and furrow the face of the land as in that portion of France that was ceded to England. De Quincey says: "Within fifty years in three pitched battles that resounded to the ends of the earth, the chivalry of France had been exterminated. Her oriflamme had been dragged through the dust. The Eldest Son of Baptism had been prostrated. The daughter of France had been surrendered on coercion as a bride to her English conqueror. The child of that marriage, so ignominious to the land, was King of France by the consent of Christendom; that child's uncle domineered as regent of France; and that child's armies were in military possession of the land. But were they undisputed masters? No!-under a perfect conquest there would have been repose; whereas the presence of the English armies did but furnish a plea, making strong in patriotism, for gathering everywhere of lawless marauders, of soldiers that had deserted their banners, and of robbers by profession. This was the woe of France more even than the military dishonour." I

1 Essay on Charles Lamb.

192 


\section{CLIFF CASTLES}

The Hundred Years' War, that has left ineffaceable traces in the south of France, began in $\mathbf{1 3 3 6}$ before the conclusion of the Treaty of Bretigny, which was in 1360, and it lasted till 1443 - over a century, though not without interruption; and it desolated the fields of Perigord, Quercy, and to a less degree Rouergue and the Limousin, and wrought havoc to the gates of Paris.

The close of the fourteenth century saw no hope anywhere, only gathering storms. In France, to the prudent Charles V. succeeded the mad fool Charles VI. In England the strong King Edward III. was followed by the incompetent Richard II. In Germany the Emperor Charles IV., a statesman, had as his successor the drunken sot Wenceslas. In England the Wars of the Roses were looming in the future. Agincourt proved more disastrous to England than to France. There was hopeless turmoil everywhere. As Luther said when a somewhat similar condition existed in Germany"God, tiring of the game, has thrown the cards on the table." In France the free Companies ran riot unrestrained. About them one word.

The engagement of mercenaries in the war between England and France had begun early. As Michelet says: "The population of the North saw appear among them mercenary soldiers, the routiers, for the most part in the service of England. Some came from Brabant, some from Aquitaine; the Basque Marcader was one of the principal lieutenants of Richard Ccur-de-Lion. The mountaineers of the South, who to-day descend into France and Spain to ain a little money by huxtering, did so in the Middle Ages, ut then, their sole industry was war. They maltreated priests as they did peasants, dressed their wives in consecrated vestments, beat the clergy, and made them sing mass in mockery. It was also one of their amusements to defile and break the images of Christ, to smash the legs and arms, treating Him worse than did the Jews. These routiers were 


\section{CLIFF CASTLES}

dear to the princes precisely on account of their impiety, which rendered them insensible to ecclesiastical censures." 1

From 1204 to 1222 was the period of the Crusade against the Albigenses. Pope Innocent III. poured over that beautiful land in the south of France-beautiful as the Garden of God-a horde of ruffians, made up of the riffraff of Europe, summoned to murder, pillage and outrage, with the promise of Heaven as their reward. After committing atrocities such as people Hell, these scoundrels, despising the religion they had been summoned to defend, with every spark of humanity extinguished in their breasts, looked about for fresh mischief, and found it, by emrolling themselves under the banner of England; their tiger cubs grew up with the lust of blood and rapine that had possessed their fathers. Generation after generation of these fiends in human form ranged over the soil of France committing intolerable havoc. A carpenter of Le Puy formed an association for the extermination of these bands. Philip Augustus encouraged him, furnished troops, and in one day slaughtered ten thousand of them. But so long as the English claim on so large a portion of the soil of France was maintained, the bands were incessantly recruited. The French King hired them as well as the King of England. So, later, did the Popes, when they quitted Avignon, and by their aid recovered the patrimony of $\mathrm{S}$. Peter.

The barons and seigneurs in the South were no better than the routiers. They transferred their allegiance from the Leopards to the Lilies, or vice rersâ, as suited their caprices. 'The Sieur de Pons went over to the side of France because he quarrelled with his wife, who was ardent on the English side. The local nobility helped the routiers, and the routiers assisted them in their private feuds.

1 Histoire de France, ii. p. 362. The first to introduce them was Henry Courtmantel when he rebelled against his father. On his death in 1163 they disbanded, and then reunited under elected captains, and pillaged the country. 


\section{CLIFF CASTLES}

The knights of the fourteenth century were no longer the protectors of the weak, the redressers of wrongs, loyal to their liege lords, observers of their oaths. They had reversed the laws of chivalry. Their main function was the oppression of the weak. They forswore themselves without scruple. The Sire d'Aubrecicourt plundered and slaughtered at random pour meriter de sa dame, Isabella de Juliers, niece of the Queen of England, "for he was young and outrageously in love." 'The brother of the King of Nararre plundered like the rest. When the nobles sold safe-conducts to the merchants who victualled the towns, they excepted such articles as might suit themselves-silks, harness, plate. A prince of the blood sent as hostage to England returned to France in defiance of treaties, and if King John surrendered himself, it was because of the ease and pleasures he enjoyed in London, and to be rid of cares. The name given to the Companies in the South was Raobadous (Ribauds) - the very name has come to us under the form of ribald, as indicative of all that is brutal, profane, and unseemly.

Among the commanders very few were English. There was the Welshman Griffith, whom Froissart calls Ruffin, who ravaged the country between the Seine and the Loire. Sir Robert Knollys, or Knolles, led a band of English and Navarrese, "conquering every town and castle he came to. He had followed this trade for some time, and by it gained upwards of 100,000 crowns. He kept a great many soldiers in his pay; and being very liberal, was cheerfully obeyed." So says Froissart. Sir Robert Cheney was another; so was Sir John Amery. Sir John Hawkwood was taken into the service of Pope Gregory XI., and sent to ravage in Italy. Bacon, a notorious brigand, may or may not have been English. The name is common in lower Brittany. "This robber," says Froissart, "was always mounted on handsome horses of a deep roan colour, apparelled like an earl, and very richly armed." 


\section{CLIFF CASTLES}

But usually the free Companies enrolled themselves under some bastard (Bourg) of a noble house in France or Guyenne. It was a bastard warfare on their side; they stood in the same relation to the regular forces that privateers do to a fleet of the Royal Navy. They paid no regard to treaties. As the Bourg d'Espaign told Froissart: "The treaty of peace being concluded, it was necessary for all men-at-arms and free Companies, according to the treaty, to evacuate the fortresses and castles they held. Great numbers collected together, with many poor companions who had learnt the art of war under different commanders, to hold councils as to what quarters they should march, and they said among themselves that, though the kings had made peace with each other, it was necessary for them to live. 'They marched into Burgundy, where they had captains of all nations-Germans, Scots, and people from every country - 'and they agreed to disregard the treaty and to surprise towns and castles as before.' A notorious Breton captain on his deathbed said: 'Such has been my manner of carrying on war, in truth, I cared not against whom. I did indeed make it under shadow of the King of England's name, in preference to any other; but I always looked for gain and conquest, wherever it was to be had." "

When they captured a town or castle, nominally for the English, they were quite ready to sell it to the French for a stipulated sum.

Froissart says that the Ribauds were "Germans, Brabantines, Flemings, Gascons, and bad Frenchmen, who had been impoverished by the war" (i. c. 204). He gives in one place the names of twenty of these captains, not one English. ${ }^{1}$ In another place he enumerates ten, all French or Gascons (ii. c. 10). Among those who harassed the

1 Robert King of Puy Guihhem was an Englishman, but an authorised governor and commander under the English crown. 


\section{CLIFF CASTLES}

Languedoc, Quercy and Perigord, not a single captain was English. The Bastard de Beby, the Bastard d'Albret, Amadeu de Pons, Benezet Daguda, De l'Esparre, Menard de Favas, l'Archipretre, Bertrand de la Salle, Le Non de Mauroux, Jean l'Esclop, Nolibarba, Bertrand de Besserat, Perrot de Savoie, Ramonet del Sort, and a score more, all base French or Gascon names. "These brigands," says Lacoste, "were mainly composed of French soldiers to whom the State had been unable to pay their wages." One whole company was entitled that "des Bretons."

But it was not the captains of the Companies alone who were Gascons, French, and Bretons. The nobles throughout Guyenne were more than half of them on the English side. The famous commander who did so much towards achieving the victory of Poitiers was a Frenchman, the Captal de Buch, Jean de Greuilly, Constable of Aquitaine for the English crown. Amandeu and Raymond de Montaut, the Sire de Duras, Petiton de Courton, Jean de Seignol, the Sire de Mussidan, and many more. "Following their interests or their passions, all these nobles passed from side to side, now that of the English, then that of the French; but they preferred the English side to the other, for war against the French is more pleasant than that against the English,"-that is to say, it was more profitable. The Livre de Vie of Bergerac under the date 5th April 1381, speaks of Perducat d'Albret as "loyally French." But his loyalty lasted but for a moment. Froissart has a characteristic passage upon the Gascons that deserves quotation. After giving a list of towns and castles on the Garonne and the Dordogne, he says: "Some of these being English, and others French, carried on a war against each other; they would have it so, for the Gascons were never, for thirty years running, steadily attached to any one lord. I once heard the Lord d'Albret use an expression that I noted down. A knight from Brittany inquired after his 


\section{CLIFF CAS'ILES}

health, and how he managed to remain steady to the French. He answered, 'Thank God my health is good, but I had more money at command, as well as my people, when I made war for the King of England, than I have now; for, whenever we took any excursions in search of adventures, we never failed meeting some rich merchants from 'Toulouse, Condom, La Réole, or Bergerac, whom we squeezed, which made us gay and debonair, but now all that is at an end.' On hearing this I concluded that the Lord d'Albret repented having turned to the French in the same manner as the Lord of Mucidens, who swore to the Duke of Anjou he would set out for Paris and become a good Frenchman. He did go to Paris, when the King handsomely received him; but he slunk away and returned to his own country, where he again became an Englishman, and broke all his engagements with the Duke of Anjou. The Lords of Rosem, Duras, Langurant, did the same" (iii. c. 21).

As with the captains of the Companies, so with the knights and seigneurs who fought in the South for the Crown of England-their names are for the most part French and Gascon, and not English. ${ }^{1}$

The Companies formed their nests in the rocks, which they fortified, or in castles they had captured, or in such as had been abandoned by the French, from inability to garrison them. The Causse was in their possession from

1 Let it not be forgotten that those who condemned Joan of Arc to be burnt were Frenchmen. The University of Paris denounced her as a heretic. Her judges were the Bishop of Beauvais, a Frenchman by birth, Jean Graveraut, Professor of 'Theology at the University of Paris, Grand Inquisitor of France, Jean Lemaitre, prior of the Dominicans at Rouen, Her bitterest accuser was the Canon Jean d'Estivet, general procurator. who after the execution drowned himself in a pool. The Bastard of Vendôme sold her to John of Luxembourg, and John of Luxembourg sold her to the English for 10,000 francs. Charles VII. and his friends did not raise a finger in her behalf. They forgot her at once, as a thing that had answered its purpose and was no longer of use. 


\section{CLIFF CASTIES}

the Dordogne to the Lot, and Perigord to the gates of the capital. They overran Aurergne, the Gevaudan, Poitou, the Angoumois, the Rouergue and the Saintonge, to speak only of provinces south of the Loire. The Government exhibited incredible feebleness towards them. In 1379 the Count d'Armagnac, Royal Lieutenant in the south, paid 24,000 francs to one of the routiers to evacuate the castle of Carlat, and 12,500 to the Bastard of Albret for five others. In 1387 he convened an assembly of the States of Auvergne, Velay, Gevaudan, Rouergue, Quercy, \&c., to debate what was to be done to rid the country of these pests. Instead of resolving on an united effort to put them down by force of arms, they agreed to pay them 250,000 francs to quit. They took the money, but remained. Every town, every village was forced to come to terms with the brigands, by means of a patis or convention to pay a certain sum annually, to save it from pillage. Should the covenanted money not be forthcoming to the day, the place was sacked and burnt.

At length the inhabitants, unable to endure the exaction of the routiers on one side and those of the King and the seigneurs on the other, migrated to Spain and never returned. In 1415, as all the inhabitants of Caudon had crossed the frontier, the curé applied to have his cure united to that of Domme. He had no parishioners left. Domme had been reduced from a thousand families to a hundred and twenty, and these would have abandoned their homes unless stopped by the Seneschal of Perigord.

In 1434 the inhabitants of Temniac and Carlux began to pack their goods for learing, but the citizens of Sarlat stopped them, by promising to feed them till the conclusion of the war. Some of the large towns had lost so many of their citizens that they were glad to receive peasants out of the country and enrol them as burgesses. In 1378, as the Causse of Quercy was almost denuded of its population 


\section{CLIFF CASTLES}

and nothing remained to be reaped, the Companies abandoned it for the Rouergue, the Gevaudan and the Limousin and Upper Auvergne. Thence the wretched peasants fled to the deserted limestone Causse of Quercy and occupied the abandoned villages and farms. They obtained but a short respite, for in 1407 the Companies returned to their former quarters. Charles VI. imposed a heavy tax on the whole kingdom to enable him to carry on the war against the English. But Quercy was wholly unable to meet the demands, and the King, in a letter dated the last day of February 1415, gives a graphic account of the condition to which the land had been reduced.

"Whereas, this land, at the time when it passed under the obedience of the King of England, was the richest and most populous in all the Duchy of Guyenne, and contained the finest cities, towns, and castles and fortresses in the said duchy, which were free and quit of all taxes and imposts, and with privileges conferred on them and confirmed by the King of France when they shook off the English yoke; and the said land of Quercy, after having returned to its legitimate sovereigns, has testified to them the greatest loyalty; yet have its inhabitants been grievously injured, assailed, beaten, robbed, pillaged, imprisoned, killed, maltreated by the English in divers ways, which enemies have since taken and occupied the greater part of the finest towns and fortresses of the land; on which account the land of Quercy has since continued in a condition of mortal warfare with the said enemies for the space of fifty-five years; and this carried on without aid from us, or from any one:- This unfortunate land has resisted to the utmost of its powers and is doing so still; and it has been surrounded for long by our said enemies, and is as it were destroyed and uninhabitable, and the greater number of its towns, castles, and strongholds have become desert and wild, covered with forest and scrub, inhabited by wild beasts, 


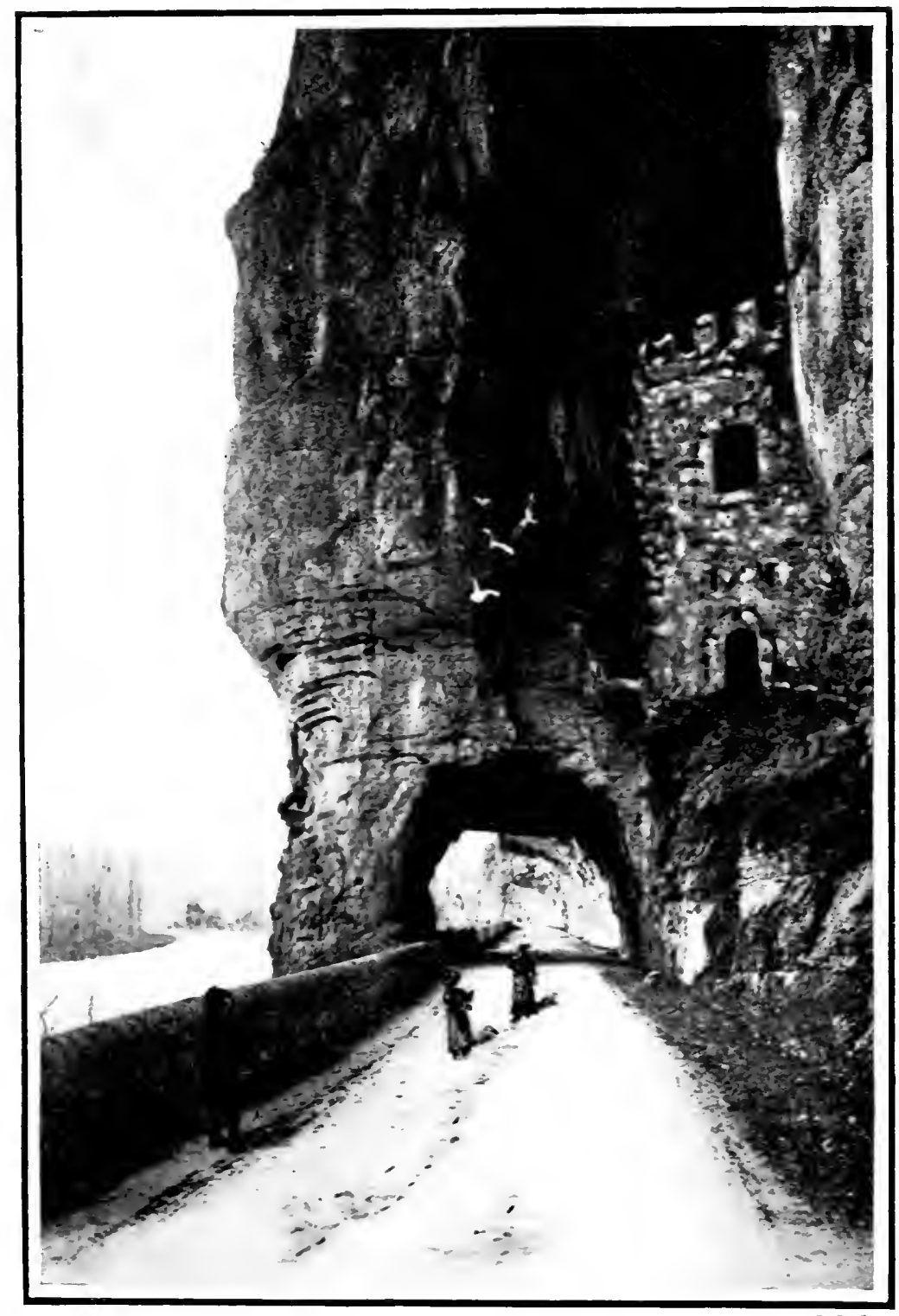

Le Defilé des A.Ngias, Lot.

A fortress of the English commanding the road ro Cahors. Several chambers are excavated out of the rock. 



\section{CLIFF CASTLES}

with the exception of some few small places that are very poor and miserable, and though at one time they were great and rich, they have been to such an extent depopulatedpartly through the war and partly through pestilences that have ensued-there are now hardly one hundredth part of the people remaining, and those who do remain are but poor labourers and men of servile class; and these are kept night and day harassed by watching against enemies, and yet are compelled to buy them off with patis and pensions, so that the greater portion of their substance is consumed in this way ;-therefore, \&c."

In 1450 the English were driven out of Guyenne, but a fresh attempt to recover it was made, that ended in the defeat and death of 'lalbot, in 1453. The Companies had then to dissolve. Out of a thousand churches in Quercy but four hundred were in condition for the celebration of divine service; many had been converted into fortresses. Most of the little towns in Upper Quercy had lost the major portion of their inhabitants; the villages were void of inhabitants. None knew who were the heirs to the deserted houses and untilled fields. ${ }^{1}$ An emigration from Limousin and the Rouergue was called for to repeople the waste places. Grammat, that had been a thriving town, in 1460 was left with only five inhabitants, Lavergne with but three. Lhern, once a flourishing place, was absolutely desert, the fields covered with briars and thorns, not one house tenanted, and in the church a she-wolf had littered her cubs.

Throughout the country can be distinguished the churches built when the war was over-quadrangular structures, without ornament.

Two of the strongest fortresses held by the English in

1 "Agros atque Lares proprios, habitandaque fana Apres reliquit, et rapacibus lupis,

Ire, pedes quocunque ferent." 


\section{CLIFF CAS'TLES}

Perigord were Bigaroque and the Roc de Tayac. The former belonged to the Archbishop of Bordeaux, staunch in his adhesion to the English cause, and he placed a garrison in it. The French did not, attempt a siege, but in 1376 they raised a large sum in the neighbourhood and bought the garrison out. Either they culpably neglected to place troops in it, or were too weak to do so, and in 1386 the English reoccupied it without a blow, and made it a centre whence they pillaged the country up to 1408 . In 1409 the Constable of France, however, laid siege to it and the garrison capitulated, on condition that all prisoners taken by the French should be set free. The French then demolished the fortifications, but did this so inefficiently that in 1432 the English had again established themselves therein. It was not recovered by the French till 1443; somewhat later the Companies disbanded, and then they so completely destroyed the fortress that of it nothing now remains.

The other stronghold was the Rock of Tayac. The white cliff streaked with black tears rises to the height of 300 feet, and is precipitous. Throughout the whole length it is lined and notched and perforated, showing tokens of having been a combination of cliff caves, and wooden galleries, connecting the caves, as also of structures at the base of the crag. These latter have disappeared, having been torn down when the castle was demolished, but the indications of the roofs remain. There were several storeys in the fortress. In one cave is a stable reached by a ladder, also a well that was driven from an upper cavern through the roof of the stable and through its floor to the level of the river. The oven of these freebooters hanging in mid-cliff remains, guard-rooms are still extant, and the,principal upper storey is now turned into a hotel, as already mentioned, but in so doing the stable has been injured and the well filled up. The hotel is reached by a ladder.

From this vultures' nest the Ribauds devastated the 132 


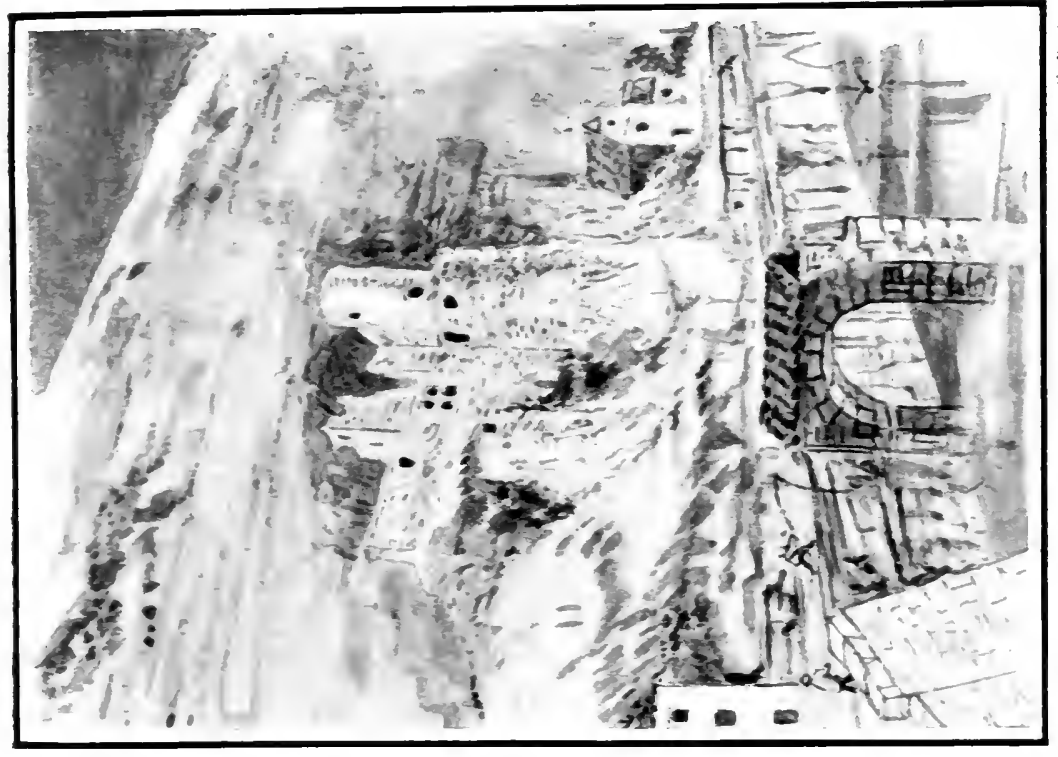

D.

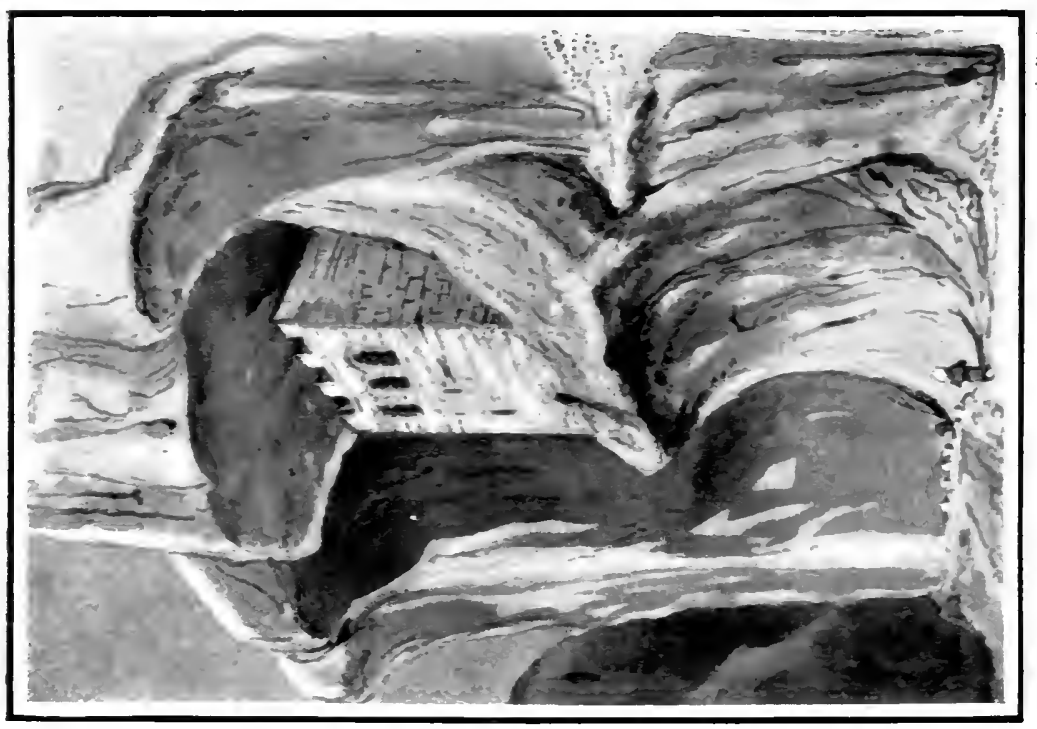

0 


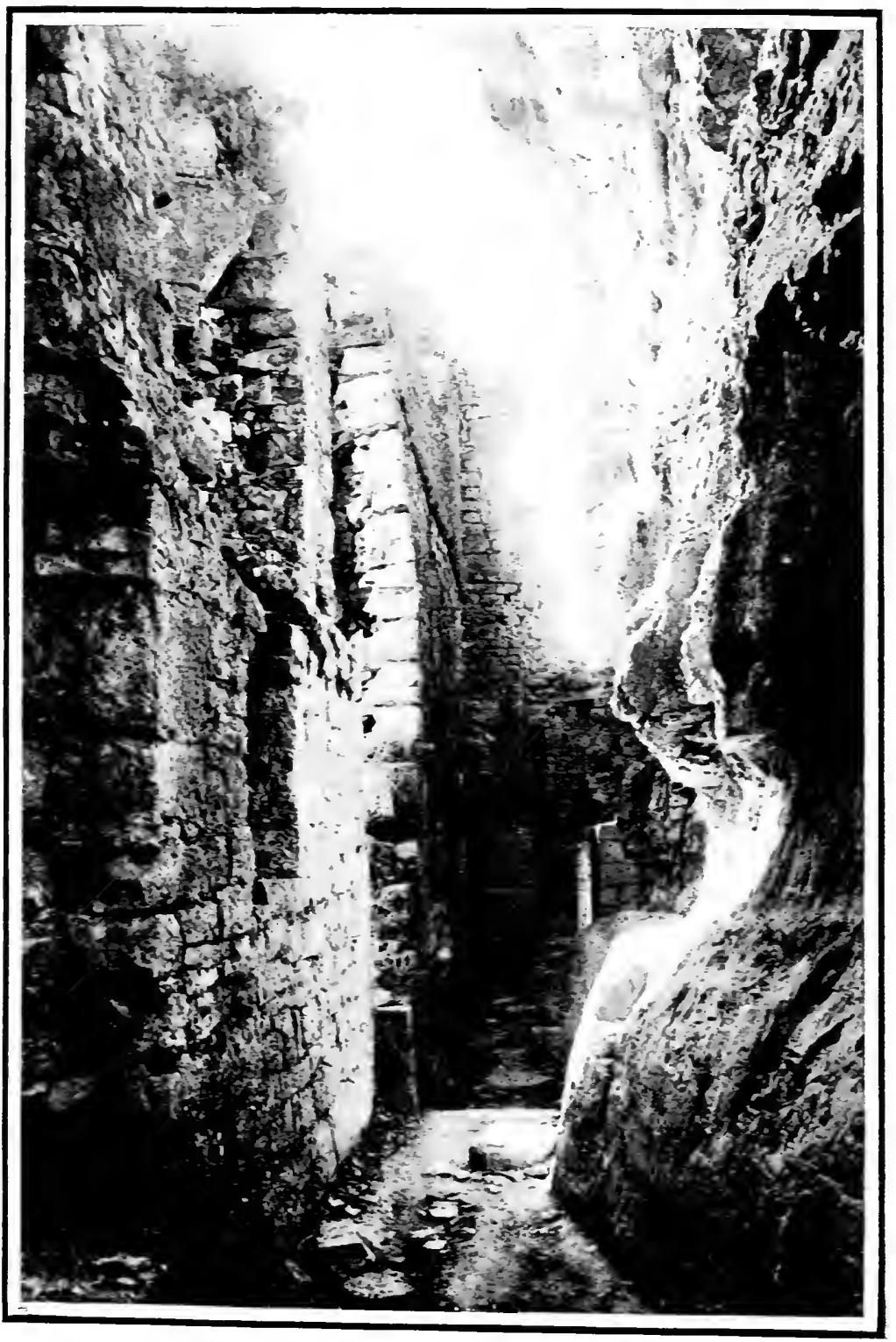

INTERIOR OF THE CHÂteAl DU DiAble, CABrerets

The rock is on one sice, the wall edying the precipice is on the other. 



\section{CLIFF CASTLES}

neighbourhood and the Sieur des Eyzies on the opposite side of the river, and who was on the French side, was powerless against them. In company with the garrison of Bigaroque they surprised Temniac near Sarlat, S. Quentin and Campagnac, in 1348, but were shortly after dislodged by the Seneschal of Perigord from these acquisitions.

In 1353 they surprised the church and fortress of Tursac and the castle of Palevez. The men of Sarlat hastened to recover Tursac, bringing with them some machines of war, named La Bride, Le Hop, Le Collard, and l'Asne, that flung stones and bolts and pots of flaming tar and sulphur. They managed to drive the English out of Tursac, but were unable to recover the other castle.

In 1401, at the solicitation of the Baron of Limeuil, they took and utterly destroyed the town and castle of La Roche Christophe, as shall be related in full in the sequel. On 4th December 1409, the Constable of France having ruined Bigaroque, besieged the Rock of Tayac, and it was taken after a gallant defence on 10th January 1410, demolished and reduced to the condition in which we see it now. Then a tax was levied throughout Perigord to pay for the cost of the sieges of Bigaroque and the Rock of Tayac.

We will now pass from Perigord to Quercy. Here the English Companies held the valley of the Lot from below Capdenac to the gates of Cahors, except the impregnable towns of Cajarc and Calvignac.

Flowing into the Lot at Conduché is the river Célé that descends from Figeac. This river was also in the grip of the English.

Below Figeac the limestone precipices first appear at Corm, and the cliff is full of caves in which there are remains of fortifications. The cliff is not beautiful, but is wondrous strange, white, draped with fallen folds of stalactite, black as ink, as though a tattered funeral pall had been cast over 


\section{CLIFF CASTLES}

it. Corn was a feof of the family of Beduer, one of the five most powerful in Quercy. In 1379 Perducat, the Bastard of Albret, an English Captain, occupied Corn, but sold it to John, Count of Armagnac, Seneschal of Quercy; after having marched out and pocketed his money, he turned round, marched in again, and set to work to fortify the caves. He made the citizens of Cajarc contribute to the expense of this proceeding, and even required them to send masons to assist him in the work; but as they were loyal subjects of the French King they demurred at this, and he substituted additional money payment for personal service. He then pushed down the Célé valley to Cabrerets near where it debouches into the Lot, and in 1383 he fortified the caves of Espagnac, Brengues, Marcillac, Sauliac, and built the château du Diable at Cabrerets. The Count d'Armagnac sent troops to dislodge him, but failed.

In the rock of Corn, a little higher up the river than the village, is the Grotto du Consulat, reached by a path along a narrow ledge. ''o this the villagers were wont to gather to elect their magistrates without interference from the Bastard of Albret. Within is a bench cut in the rock, and the roof is encrusted with stalactite formations like cauliflowers. Immediately above the village is a much larger cavern 72 feet high and 36 feet deep. It is vaulted like a dome, and tendrils of ivy and vine hang down draping the entrance. Violets grow in purple masses at the opening, and maiden-hair fern luxuriates within. At the extreme end, high up, to be reached only by a ladder of forty rungs, is another opening into a cave that runs far into the bowels of the Causse, to where the water falls in a cascade that now flows forth beneath the outer cave and supplies the village with drinking water and a place for washing linen. Hard by the great entrance is another cave situated high up, and called the Citadel, much smaller, access to which 134 


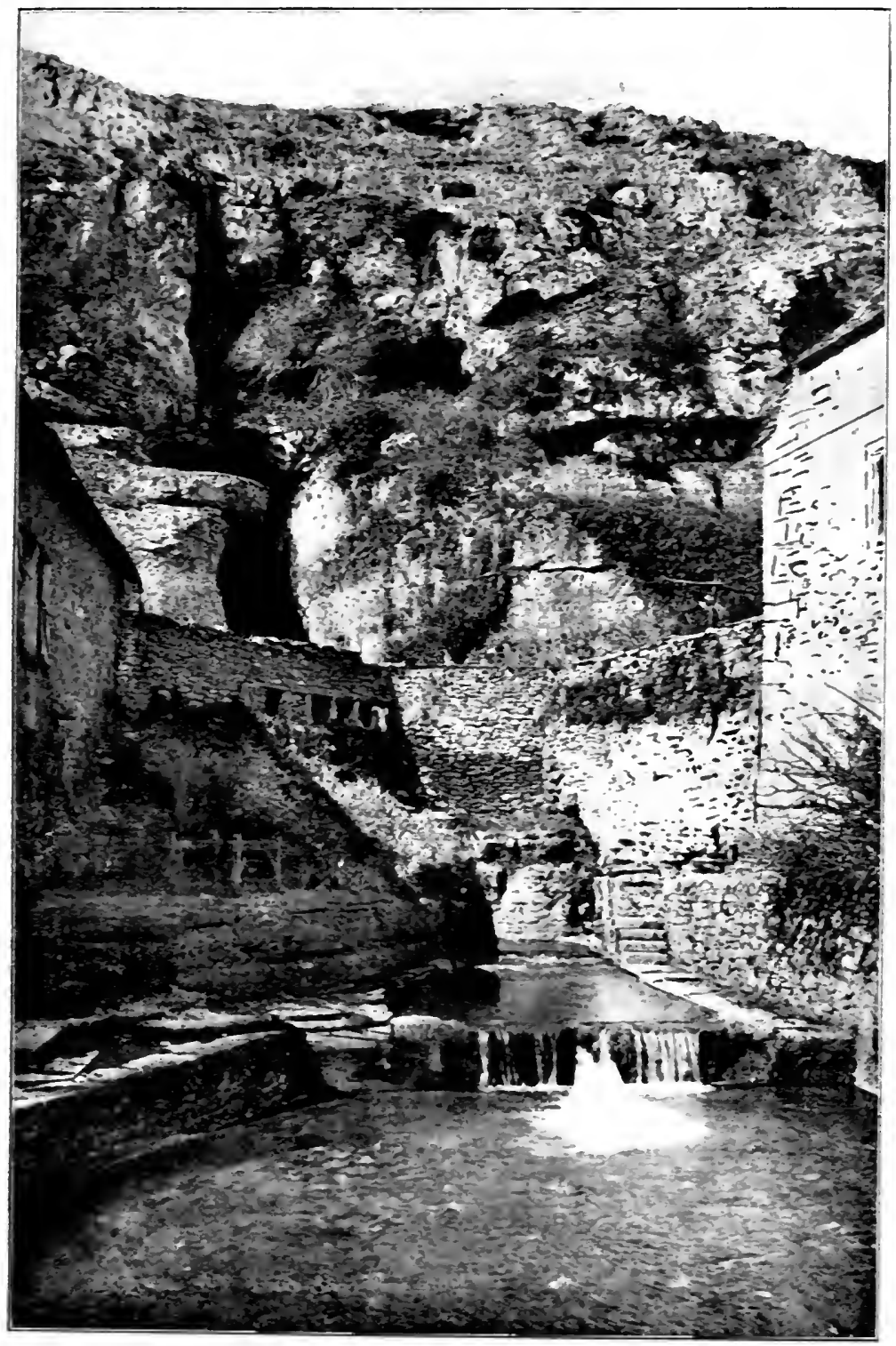

Cons, Lor

Caves arcupied by the Routiers. That above the large one was formeriy reacted by a grliery of wood. It contains the stone table at whin the Koutiers gambed and dran: 


$$
\text { . }
$$




\section{CLIFF CASTLES}

is obtained by a narrow track in the face of the rock, with notches cut in the limestone to receive the beams and struts that supported a wooden gallery which once provided easy access to the care. I did not myself climb up and investigate the citadel, not having a steady head on the edge of a precipice, and what information I give was received from the curé, who seemed very much amused at my shirking the scramble, and thought that the Englishman of to-day must be very different from the Englishman of the fourteenth century who crawled about these cliffs like a lizard. According to him, the cave within shows signs of having been occupied, and has in it a squared and smoothed block of stone nine feet long, at which Perducat and his ruffians doubtless caroused, as at a table.

In the village of Corn is the picturesque chateau of the family of Beduer built after the abandonment of the place by the English. It is now occupied by poor families. A little farther down the valley is the castle of Roquefort, which was also annexed by the Captain. It is near the Church of S. Laurent, where was a village that was destroyed by the Company. The church itself was blown up later by the Huguenots. Roquefort is dominated by a precipice, at the foot of which lies a huge mass of rock that has broken off from the cliff, and on this rock a castle has been erected. It belonged to the family of Lascasas. One of these fell at Résinières in a duel with the Seigneur of Camboulet; but his adversary survived him only a few minutes, and both were buried on the spot with three stones at their heads and two at their feet. When the new road was being made their skeletons were found. The stones remain in situ.

In 1361 Cahors was in possession of the English. The bishop unwilling to recognise the King of England as his sovereign retired to the Castle of Brengues in the Célé valley that pertained to his family, the Cardaillacs, and thence 


\section{CLIFF CAS'TLES}

governed his diocese. There he died 3rd February 1367, and his successor also occupied the Castle of Brengues. But in 1377 it was captured by an English Company under Bertrand de la Salle, and in 1380 it was held by Bertrand de Besserat, to whom it was delivered over by Perducat d'Albret.

There are two vel'y remarkable castles at Brengues; both were fortified by Perducat and Besserat. One hangs like a swallow's nest under the eaves of the overhanging rock, and is now wholly inaccessible, so much so that it is in perfect preservation. The river flows far below, and a talus of rubble runs up to the foot of the cliff, along which talus, on a narrow terrace, is a path. This path was defended both above and below the castle by gates that were battlemented and to which guard-rooms were attached. The pensile castle is not large. It was entered at one side, and has in its face three roundheaded windows.

The other castle of Brengues is perforated in an angle of rock, at a great elevation, and consists of several chambers. The cave at the angle was walled up and furnished with doorway and windows.

Near where the Céle flows into the Lot is the little town of Cabrerets. Here the precipice of fawn-coloured limestone overhangs like a wave, curling and about to break. On a ledge under it, and above the river and the road and the houses, is the Devil's Castle, built by Perducat d'Albret and Bertrand de Besserat. 'The latter held it from 1380 to 1390 , but then, at the entreaty of the neighbourhood, the Seigneur Hebraud de Saint-Sulpice at the head of levies laid siege to the castle and took it.

'The castle has one of its walls of rock; only that towards the river and the two ends are structural, as is also a round tower. A portion of the castle has been pulled down; it has served as a quarry for the houses beneath, but a good deal still remains. The tower is about 20 feet in diameter. 'The 136 


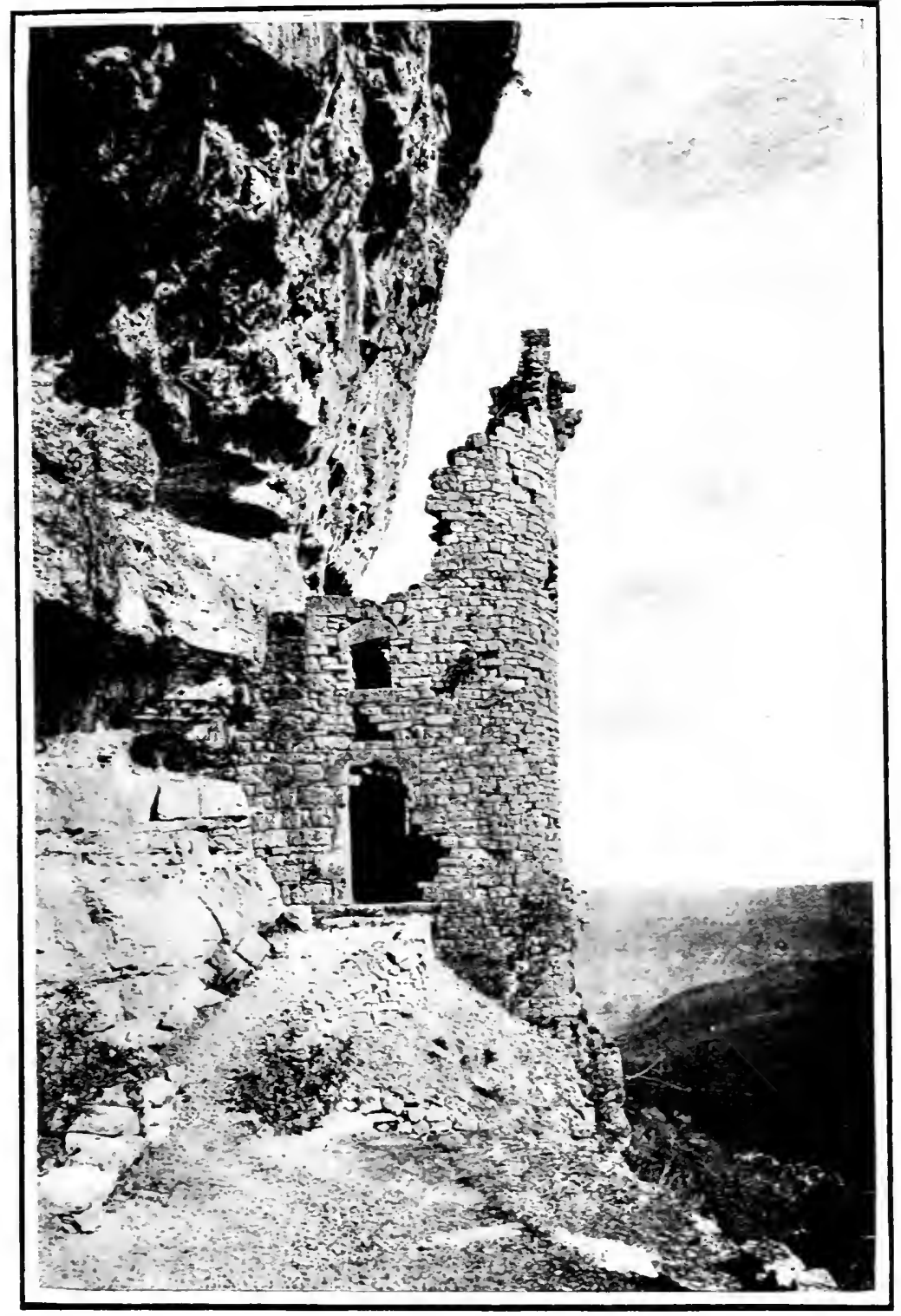

Château de: ANglais, AUtorre

Reached by a sharp scramble up a steep, and then by a led te in a precipice. Some chambers are scooped out $0^{*}$ the roch. When the English were besiezed, they escaped by a goat.path to a point whence hung a rope from a tree above, and up this they swarmed. 



\section{CLIFF CASTLES}

entrance hall, lighted by windows, is 70 feet long and 40 feet wide. A second hall, partly hewn out of the rock, with recesses for cupboards and seats and with fireplace, is 42 feet long. The oven remains in a ruinous condition. The castle is reached by steps cut in the rock.

Below Conduché, where the Célé enters the Lot, the road runs under tremendous precipices of orange and grey limestone, in which the track has been cut; and the road would be totally blocked by a huge buttress split down the middle had not a tunnel for it been cut. As the Roman road ran this way, the original tunnel was made by the Masters of the World, but it has been widened of late years. Commanding the road and the tunnel, planted in the cleft of the rock, is a castellated structure, that also owes its origin to the captains who fortified the Célé caves.

None could pass up or down the road without being spied and arrested, and made to pay toll by the garrison of this fort. ${ }^{1}$

The Cahors Chronicle says of this period: "Deinde fuit in praesenti patria mala guerra. Anglicis et Gallis hinc inde reprædentibus, unde evenit victualium omnium maxima caristia. Nullus civis Caturci villam exire erat ausus, omnia enim per injustitiam regebatur." If the merchants and provision wains for Cahors were not robbed at the Défilé des Anglais, they were subjected to toll. The interior of the chasm reveals a whole labyrinth of passages and vaults dug out in the heart of the calcareous rock. The chambers had openings as windows looking out upon a river, and the rock was converted into a barrack that could accommodate a large garrison.

The last of the rock fastnesses of the routicrs that I purpose describing is of a totally different character from the rest. It is at Peyrousse in the Rouergue, in the

1 So early as the eleventh or twelfth century there was not a small river, as the Célé and the Aveyron, on which tolls were not levied. 


\section{CLIFF CASTLES}

department of Aveyron. Peyrousse is a village, but was once a fortified town on a height, with its church and church tower standing on the highest point and visible from a great distance. It rises above a deep valley or ravine. The houses are all old, and many of them in ruins. The church, dating from 1680, is not ineffective; there are, however, the ruins of a Gothic church farther down the hill. One of the embattled gates of the town is still standing, as well as a tower erroneously supposed to be the bell tower of the ruined church, actually part of the fortification of the place. Projecting from the side of the hill on which stands Peyrousse, partly attached to it, but for the most part detached, is a ridge of schist starting 300 feet above the stream below, in one sheer precipice, and precipitous on every side. It is perhaps 300 feet long, and rises like a blade of an axe; at each extremity of this ridge is a lofty tower-one, the farthest, open at the side. To erect these towers it must have been necessary to level a portion of the sharp edge on which they rest. Between them one could walk only with a balancing pole like a tight-rope dancer, as there is a sheer fall on each side. The rock is called Les Roches du Tailleur, as having been appropriated by a captain who cut folk's coats according as he wanted the cloth. How the builders climbed to this height, how they managed to carry up their material, and how they achieved the building of these towers, is impossible to conjecture. The tradition is, that when the English quitted Peyrousse they destroyed the means of ascent, and since 1443 no human being has been able to climb the rock and visit the towers, that for nearly five bundred years have had no other denizens than ravens and jackdaws. But that is not all the puzzle of the 'l'ailor's Rock. It is supposed that there was a wooden castle between the towers. There is no indication of there having been a stone structure. 


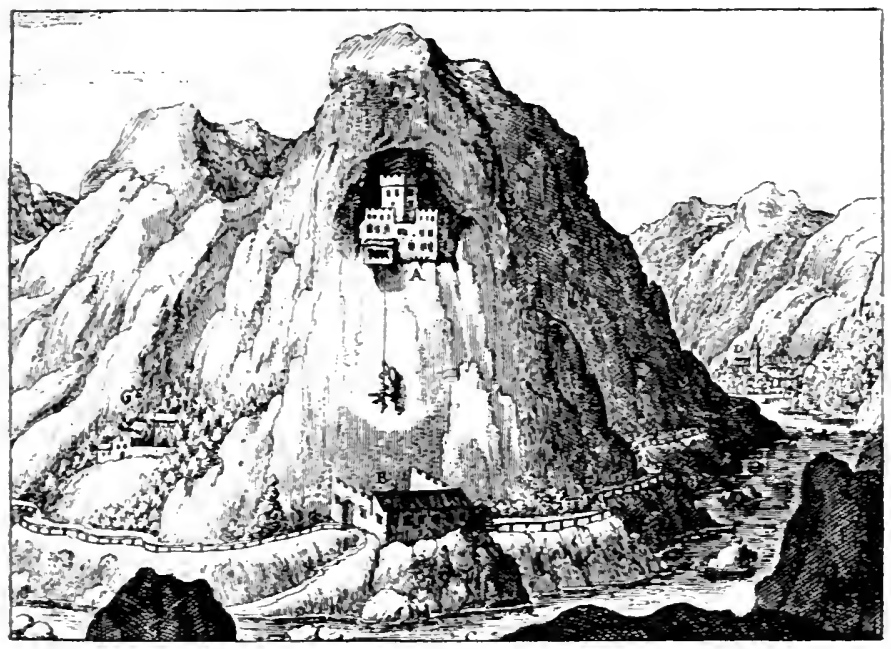

COVOLO, FROM A PRINT BY MERIAN, I6 40 -I 648

In the defile of the Brenta; roo feet above the road. It was capable of containing a garrison of 300 men. It was taken from the Venetians by Maximilian in 1509. It is between Primolano and Cismone.

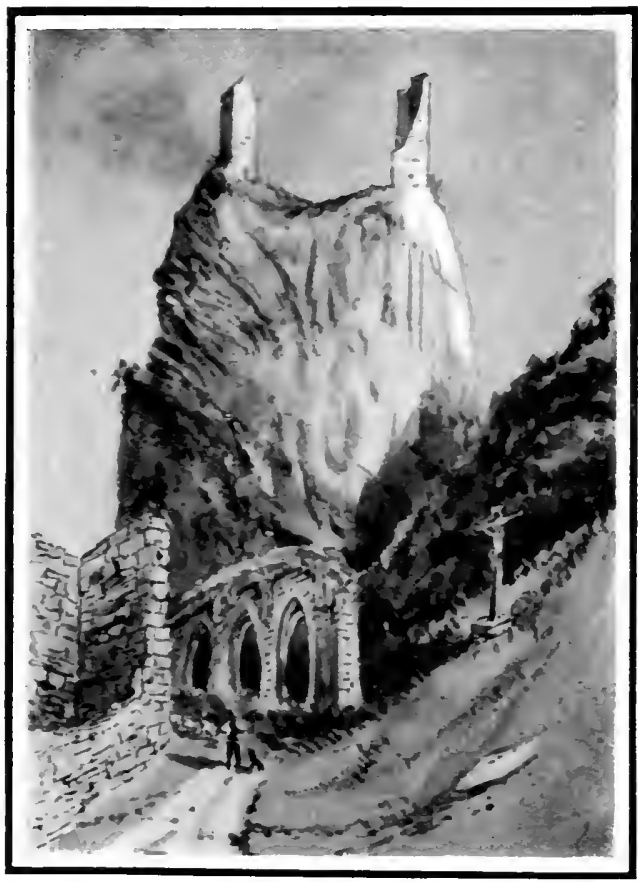

LA ROCHE DU TAILleUR

Remains of a castle on a precipitous rock at Peyrousse, Aveyron; it was held by the English Routiers, who, when they abandoned it, destroyed the means of access, since which time it has been inaccessible. 


\section{CLIFF CASTLES}

But if so, how was it balanced, or how secured? A plank cast across the blade would make a see-saw for an ogre and ogress, till cut through. I endeavoured with a glass to see whether notches had been hacked in the schist to receive stays, and others on the ridge to accommodate joists, but could distinguish none.

Peyrousse became a Calvinist stronghold in the Wars of Religion, when the churches were destroyed; but the Huguenots made no attempt to climb the 'Tailor's Rocks and restore the castle. At the foot of the crags are the remains of the chapel of the garrison. How did they descend to it and mount again? I presume by a knotted rope.

A cliff castle that bears a curious resemblance to Peyrousse is 'Trosky, in Bohenia, but in this latter case the rocks are of basalt, and between the two towers the connecting rock forms a deep depression. In 1415, Johann von Herzmanmiestetz and Otto Berka of Trosk sacked the monastery of Opatowitz, butchered most of the monks, tortured the abbot so that he died a few days later, and carried off all the plunder they could collect. With the spoil Otto Berka built a castle on the two spires of rock, a tower on each, and connected them with a crescent wall, and a gallery of communication. The walls were six feet thick, and the foundations clamped to the rock with iron. He also contrived a tunnel, cut in the rock to the bottom, to enable himself and his men to ascend and descend. In 1424, however, Otto Berka was there no more. The castle was besieged by the terrible one-eyed Hussite commander, Ziska with the Flail, and he succeeded in capturing the lower tower after great loss of life, but entirely failed to take the upper donjon. After the departure of Ziska the castle was taken as a residence by Margaret, widow of Otto Berka, who secured the lower tower, and her granddaughter Barbara occupied the 


\section{CLIFF CASTLES}

higher. These women hated each other as poison, and to personal hate was added religious rancour, for Barbara had embraced the party of the Utraquists. The theological quarrel was simply about the use of the chalice at communion. The Roman Church had withdrawn it from the people; the Utraquists asserted their right to it; and about this question the two parties fought and slaughtered each other, and burnt towns and castles. The tradition is that all day long, and part of the night, the two women screamed abuse at each other from their several towers, and desisted only for their meals, their devotions, and necessary sleep. Folk passing along the highway would halt and listen to the yelling and vituperation of the two shrews. Each had her own chapel at the foot of the cliffs, in which each ostentatiously followed the rite of which she approved; and to this day the chapels remain. According to the local story, the cries of the women were so strident and so continuous that all birds were scared away from 'lrosky. At length Margaret died, and Bertha had become so accustomed to scolding at the top of her voice, that she died soon after from dissatisfaction at having lost the object of her abuse.

In 1468 'Trosky was the property of William von Hasenburg, who sided with King Mathias against George Podjebrad. After the defeat of Mathias, Podjebrad captured Trosky, but as the owner came to terms, he was allowed to retain his castle. The towers are all that remain of the castle; the curtain wall has been broken down. 'Ihe lower tower can be reached by a climber with a steady head, but not without risk of life. 'The higher tower is quite inaccessible. From the height a magnificent prospect is obtained, with Prague in the distance.

To return once nore to the routiers.

Near Mont Dore is the Roche de Sanadoire, 3660 feet high, composed of phonolith and basaltic prisms. On the 140 


\section{CLIFF CASTLES}

top stood the fortress of the routiers, calling themselves English, under a Captain Chennel, from 1378 to 1386, when he was caught, conveyed to Paris, and broken on the wheel. It is not to be wondered at that the memory of the terrible times of the English domination, and its consequence, the reign of the routiers, should linger on in the memory of the people; that every cliff castle should be a Château des Anglais, or a Château du Diable-they mean the same thing. 'The peasant reads but little-history not at all; but Jean Bonhomme looks up at the cliffs and finds the story of the past graven there; and just as the twinge of a corn is still felt after the foot has been amputated, so - though the English rule has passed away, three hundred and fifty years have intervened-he still winces, and curses the haunts "de ces cochons d'Anglais," though in fact ces cochons were his own compatriots, doubled-dyed in iniquity, as traitors to their country and their King. 


\section{CHAP'TER VI}

\section{CLIFF CASTLES-Continued}

TOOK the third of the classes into which I have divided my subject of cliff castles, first of all; and now I shall take the others in the category.

The Seigneurs were not greatly, if at all, to be distinguished from the Captains of the routiers in their mode of life and in their fortresses, save only this, that the latter were elected by their followers, and the former were on their hereditary estates and could demand the services of their vassals. In the matter of scoundreldom there was not a pin to choose between them. But the routier chiefs were not tied to any one castle as their home; they shifted quarters from one rock to another, from one province to another as suited them, whereas the seigneur had his home that had belonged to his forefathers and which he hoped to transmit to his son.

I will give but an instance.

Archibald V. (1861-1397) was Count of Perigord. He was nominally under the lilies, but he pillaged indiscriminately in his county. Surrounded by adventurers he pianted his men in castles about Perigord, and from that of La Rolphie "hung over the city like the sword of Damocles," menaced Perigueux. One little town after another was pillaged. He intercepted the merchants on the roads. At S. Laurent-du-Manoir his captains added outrage to injury, for they took all the women of the place, and cut off their skirts at the knees; and one who made strenuous resistance they killed. 


\section{CLIFF CASTIES}

In 1385, the Seneschal of Perigord, in the name of the King of France, ordered Archibald to desist from his acts of violence. When he refused, his lands were declared confiscated. But who was to bell the cat? He mocked at the sentence, and was roused to fresh incursions and pillages. At last in 1391 the Parliament acted, and summoned the Count to appear along with twenty-three of his accomplices before its bar "to answer for having overrun with his troops the suburbs of Perigueux; for having assaulted the city, and neighbouring places; for having wounded and killed a great many persons; for having incarcerated others to extort a ransom from them; for having, like common highwaymen, seized cattle, fired granges, mills, houses; and for having committed crimes so infamous, so ferocious, that one would feel pain to disclose them."

Archibald paid not the slightest regard to the summons or to the sentence pronounced against him in contumaciam. The law could not enforce its judgment, and six years later in 1397 he died. The King refused to recognise his son Archibald VI. as Count of Perigord, but Archibald disregarded the refusal, and openly sided with the English. $\mathrm{He}$ successfully resisted the troops sent against him, and continued in the same courses as his father. At last he was brought to bay in Montignac, where he was constrained to capitulate. He was sent to Charles VI., but effected his escape and fled to London in 1399. Thence he returned in 1404, and captured Auberoche, much about the time of the English victory at Agincourt. He died in undisturbed possession of his county of Perigord in 1430.

Few portions of France so lent itself to the requirements of the feudal tyrants of the Middle Ages, as they did also to those of the routiers, as the volcanic district of Auvergne. There the floods of lava that flowed from the volcanoes have formed caps to hills, with precipices on every side, cut 


\section{CLIFF CASTLES}

through by the streams, that have separated portions from the main current. Every such peak or fragment of plateau was laid hold of by the seigneurs of old, as sites for their fortresses. From the number of these strongholds and the almost impregnable nature of most of them, the feudal tyrants of Auvergne were able to hold their own, long after the rest had been brought to their knees; and it was not until Richelieu with iron hand moved against them that their career of rapine and violence was curbed. Beginning in 1626, Richelieu ordered the demolition of all feudal fortresses that were not necessary for the defence of the frontiers, and which were a permanent menace to the King's authority, and an object of terror to town and country, and to the nobles afforded reminiscence of past lawlessness. The demolition was entrusted to the communes themselves. And in order to bring the culprits to speedy judgment, he renewed the institution of the Grand Jours; that of Poitiers in 1634 condemned over two hundred nobles convicted of exactions and crimes.

But it was impossible in many places, notably in Auvergne, for the communes to get hold of the castles and blow them up. There, for some thirty years longer, the seigneurs defied justice, and it was much the same elsewhere. On the 31st August 1665, the Grand Jours were announced for all the centre of France, but notice that they were to be held had been given so long before that the guilty were allowed plenty of time to escape out of the country, go into hiding or come to terms. Great were the expectations of the people. Right was at length to prevail over Might. The Day of Judgment was coming on the oppressors. The Mighty would be put down from their seat and the humble would be exalted in their room. A peasant wearing his cap before a noble, the latter knocked it off his head "Pick it up," said the peasant, "or the King will cut off your head." The seigneur obeyed. 


\section{CLIFF CAS'TLES}

But the result was disappointing. Only one noble had his head cut off. Few executions were carried into effect, many were on paper. One of the latter, a ruffian steeped in blood, defied the sentence and was banished. Fléchier in his amusing and instructive book, Les grands Jours d Auvergne, has given us a dramatic account of the trial.

Every description of intrigue was had recourse to, in order to neutralise the effect of justice. The fair ladies of Clermont, les chats fourrés, as Fléchier calls them, did their utmost to reduce the severity of the judges. The Great Days lasted three months, and ended in disappointment. Many of the worst offenders, convicted of atrocious crimes, entered the Royal service and fought in the armies of the King.

But if justice spared the culprits, the opportunity was accorded to destroy their strongholds, and now little remains of these 'Towers of Iniquity but the foundations, and some fragments of their massive walls, which were generally constructed of basaltic prisms taken from the rock that sustained the castles, laid horizontally. "Puzzolana was mixed with the mortar used in these constructions, and without the binding quality communicated by this ingredient, probably no cement would have taken effect on the smooth and iron surfaces of the prisms." 1

The King had indeed desired that greater severity should be used. He wrote to the judges: "You must manage to banish oppression and violence out of the provinces. You have begun well, and you must finish well." At the conclusion he had a medal struck representing a slave rising from the ground, under the protection of the sword of royalty, and with the expressive device, Salus provinciarum repressa potentorum audacia.

It was, however, rather the destruction of the nests than the punishment of the Vultures that effected the work.

1 Poulett Scrope, "The Extinct Volcanoes of Central France," Lond. 1858. 


\section{CLIFF CASTLES}

The Marquis de Canillac, one of the worst, escaped into Spain. He had maintained twelve ruffians, whom he called his Apostles, who catechised with sword and rod all who rebelled against his exactions. He levied taxes on necessary articles of food, and when his vassals abstained from food he fined them for not eating. He allowed none to marry without paying into his hands half the dot of the bride. His kinsman, the Vicomte Lamotte-Canillac, was the one culprit executed.

The river Vézère, opposite to the prehistoric caves of Moustier, makes a sudden bend about a wall of chalk 300 feet high and 1500 feet long. "Of all the rocks that have served for the habitation of man, this is the most striking for its dimensions and for the number of habitations it contained, if one may give that name to the excavations which the hand of man has appropriated to his use. Staircases were carved in the rock, carried half-way up the height, to where the cliff has been excavated, its recesses enlarged and divided into compartments." 1

This bluff is called La Roche S. Christophe. It arrests attention at once, for half-way up it is furrowed horizontally as though worked by a giant's tool. If the visitor approaches the cliff, he will find that the masses of rock that have fallen from above, as well as others that have formed spurs, have been extensively worked to form town walls, gateways, a church, a monastery, and dwelling-houses.

One gateway, bored through the rock, has a guard-room or sentinel's watch-chamber scooped out of a pinnacle. But not a roof remains, not a living soul is to be seen in the street, not a huxter's stall in the market-place, only tiles strewn about and white rocks blackened with smoke show that man lived there.

By a flight of stairs cut in the rock, the visitor can ascend to the furrow in the face of the cliff, and there he finds

1 De Roumejoux, Bulletin de la Soc. Hist. de Perigord. T. xix. 1892. 


\section{CLIFF CASTLES}

that the whole has been elaborately utilised. There are chambers excavated in the chalk that were formerly closed by wood partitions, with recesses for beds, cupboards, seats -clearly the bedrooms of ladies. The grooves into which the planks were fitted can be made out. Doors were fitted into rocky rebates to move on their hinges, the hinges being round prolongations of the door frame turning in holes sunk in floor and roof. The kitchen is there, the bakehouse with its oven; the guard-room with its benches for the troopers, cisterns, store-chambers, closets, cellars, a chapel, and the latrines. All but the last are on a level in one long row, with the cliff descending precipitately from the gallery that precedes the apartments and gave communication between them and which, in part, had been widened by means of a wooden balcony and railing. The chapel, if that be the walled structure in a hole of the rock, is now inaccessible. Its destination is uncertain. The peasants so designate it.

Fragments of earthenware vessels and of tiles lie on the floors. I could find nothing else.

Above the principal gallery are others of less importance that can only be reached from the top of the cliff.

This Roche Saint Christophe has a history. It was first fortified by Frotarius de Gourdon to resist the incursions of the Northmen. He was assassinated at Mourcinez in Coursac in 991. There was a priory in the town below, mention of which is found in a charter of $118 \%$.

The remarkable range of chambers and structures in the face of the precipice formed the castle of the family of Laroque. It was a worthy family, greatly respected in the neighbourhood, and loyal to the crown of France. The seigneur was the protector of the little town that lay below.

On Passion Sunday, 1401, the townsfolk and the occupants of the castle were gathered in the church, when a 


\section{CLIFF CASTLES}

cry was raised that the enemy had swarmed over the walls and were in the town. Adhémar de Laroque was the seigneur at the time. He hastened from the church, but already the street was full of English, and escape to his castle was cut off, as they had secured the stair.

Adhémar had a personal enemy, one Jean Ducos, a kinsman of the Baron de Limeuil. 'These men, calculating that the garrison of La Roque would be off its guard on that holy day, arranged with the English garrison of the Rock of rayac to surprise the town.

They came upon it unobserved, and breaking in, massacred the people and the guards; then ensued a general pillage, and a conflagration. Every house was fired after it had been ransacked, and the English Ribauds running along the platform with torehes in their hands, applied the flame to everything combustible-doors, galleries, partitions, rafters - all blazed, and the only portion of the castle and town that was left unconsumed were the latrines, to which they did not consider it worth their pains to apply their torches.

From that day to this the town of La Roche Saint Christophe has been abandoned. No cottager has ventured to repair the ruined habitations for his own use; as the place is esteemed haunted, notably on the night of Passion Sunday, when a ghostly train of the dead is seen flickering in and out of the rocks and ruins by the light of the Easter moon.

But the castle was again tenanted for awhile by a band of Huguenots, who committed such depredations in the neighbourhood that on 30th March 1588, the Viscount of Aubeterre, Governor of Perigord issued orders-" as the enemies of the King occupying this Castle are doing incredible mischief to the poor folk of the neighbourhood," that they should be expelled and the castle be utterly destroyed. ${ }^{1}$

1 La Roche S. Christophe is mentioned in the letters of Petrarch. Labbé. Frag. Ep. Petrarchi. 


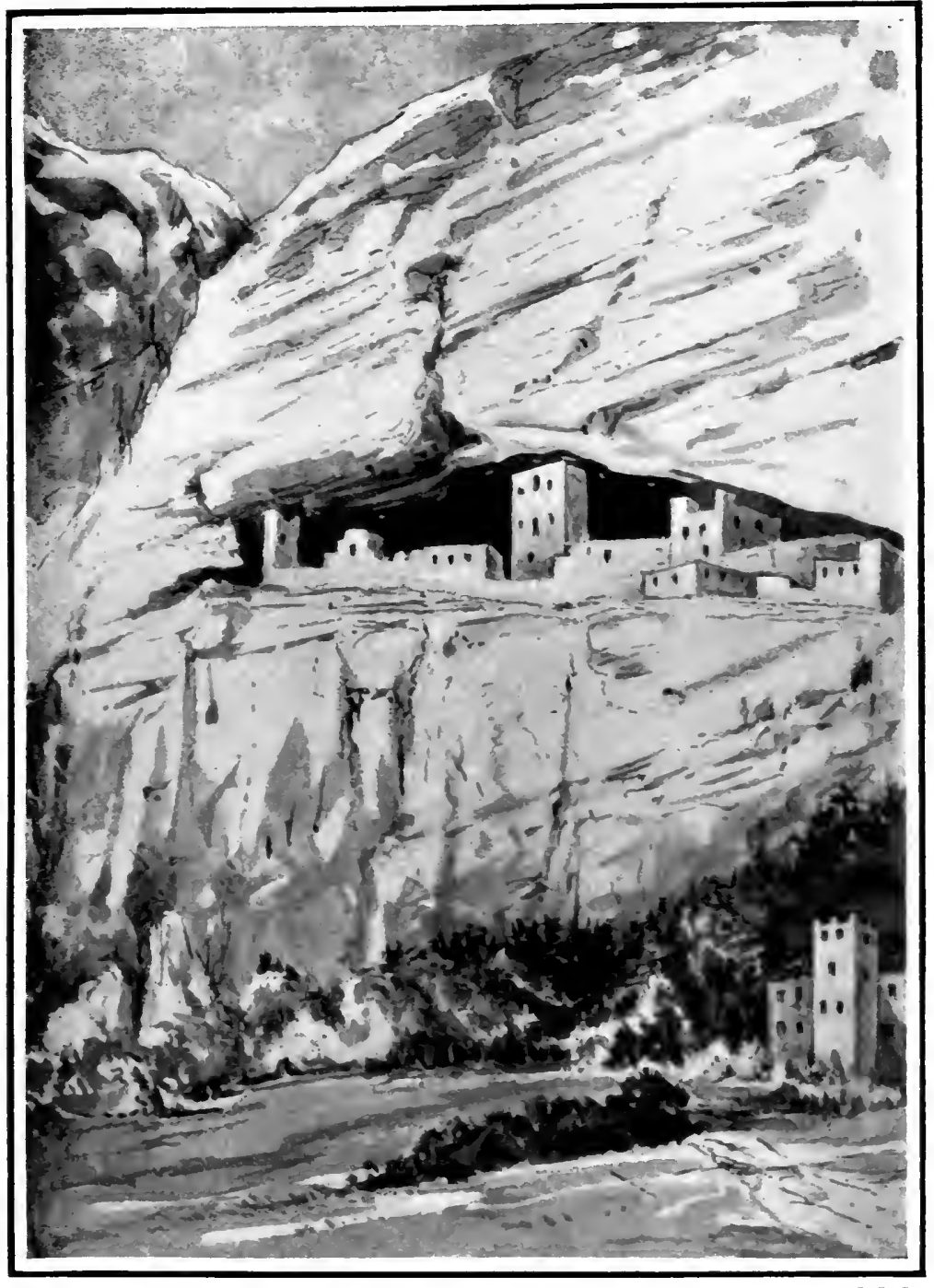

KRONMETZ

This cave castle was nominally held by nobles in feof to the lishop of Trent, but it actually became a den of robbers. It was taken by storm in 12to. Count $r$ Firmian, to whom it belongs, has built for himself a more convenient residence at the foot of the rock. 



\section{CLIFF CASTLES}

Quite as curious, and with a less tragic history is La Roche Gageac on the Dordogne, below Sarlat. "Ma chère patrie," wrote the old chonicler, Jean Tarde, " une petite ville bien close et très forte dépendant de la temporalité de l'evesque de Sarlet, la quelle ne fut jamais prinse par les Anglais."

'The white Jurassic limestone dappled orange, fawn colour, and silver grey, rises 250 fect above the river, the lower portion is in terraces, very narrow, on which are the houses clinging to the rock, cramped between the Dordogne and the cliff which rises 140 to 160 feet above. The old houses are echeloned along the face of the rock, superposed the one on the other, calcined by the sun as they face south, and the rock behind cuts off all northern winds and reflects the glare of the southern sun. This explains the vegetable precocity of the spot, where wallfowers, cactus, roses, luxuriate. It would be too hot were it not for the abundant springs, and the proximity to the Dordogne down which a cool air is wafted.

The habitations are either partly or wholly caves, they do not reach half-way up the rock which overhangs to the west. In the face of the cliff are two castles built into its recesses, one pertained to the Bishop of Sarlat, and the other to the Fénélon family. Both were ideals of a stronghold in the Middle Ages, impossible to escalade or to undermine. In the fifteenth century La Roche Gageac was a walled town containing five chateaux of noble families, juxtaposed and independent of each other, although comprised within the same enclosure. Originally indeed all were under the Bishop of Sarlat, but the Popes had set the example of jobbery for the benefit of their sons and nephews, and the Bishops were not slow to follow the lead. One Bishop made over the principal castle to his brother as a hereditary feof, and others disposed of the rest for money down, so that by the second half of the sixteenth century the town had been dis- 


\section{CLIFF CASTIES}

membered. Although it had held out against the English, when thus broken up among several, it could not defond itself against the Calvinists, who took, burned and sacked it in 15\%4. They killed three Sarlat priests. It was retaken by the Royal troops in $\mathbf{1 5 7 5}$, but it again fell into the hands of the Calvinists in 1588, and the wreckage of its ecclesiastical buildings dates from those two captures.

'The principal castle, that whichıbelonged to the Bishop of Sarlat, occupies one of the profound horizontal furrows in the face of the rock, that are so common in the limestone and chalk formations. It consists of three towers, two of which are square and one round, with curtains uniting them, and a gate-tower, to which a flight of steps cut in the rock gives access for a part of the way. But to reach this flight one has to mount by a series of posts serving as steps driven into sockets in the rock, with only here and there a sustaining iron bar. Below the structure are chambers, possibly prisons, but more probably store rooms dug out of the rock. In this castle one of the Bishops of Sarlat, in stormy times, lived continuously, and there died. How was his body carried down the stair? Probably it was lowered by ropes.

I cannot quit La Roche Gageac without a word on one of its most illustrious natives, Jean Tarde, born there in 1561 the friend of Galileo, and who, the first in France, five years after the great Florentine had begm to search the skies with his telescope, invented one year previously, erected his tube here at one of the openings of this eagle's nest, and during ten consecutive years pursued his astronomic studies. He was a remarkable man in many ways. He was the first to map his native Perigord, and the first to write a chronicle of the diocese of Sarlat, a valuable work for any who would compile a history of the Hundred Years' War, the first also to repudiate the accepted attribution of the dolmens as altars of sacrifice, and to indicate their true character as 


\section{CLIFF CASTLES}

sepulchres. His account of the ravages committed by the Huguenots is also valuable. The year before his birth, in 1560, at Lalande, the Calvinists got into the town through a hole in the wall, killed the first Consul, the Vicar, and six other priests, and massacred a hundred of the inoffensive citizens. Sixty took refuge in the church. The Calvinists forced such as could to ransom their lives, and slaughtered such as were too poor to do this. He was but six or seren years old when the Huguenot captain, the Sieur d'Assier, took La Roque, "killing the priests and burning the churches." He was aged twelve when Captain Vivant took Sarlat, suppressed the bishopric, and killed three of the canons and several of the citizens. At La Chapelle-Faucher in 1569 the heretics drove 260 peasants into the castle and massacred them all. He was made Vicar-General to the Bishop of Sarlat, and it was after having made a tour of the diocese in 1594 that the idea occurred to him to write the history of his country and repair as far as possible the loss of so many of the archives that had been burnt. In 1599 he was made honorary chaplain to Henry IV., and in 1626 was published his Description du pais de Quercy. His history of Sarlat, after remaining in MS. was at length published in 1887, but only 150 copies were printed. Happily one is in the British Museum, and I possess another.

Gluges is on the Dordogne near Martel, where high up in the cliff, difficult of access, is the fortified cave-castle of Guillaume Taillefer, son of Raymond IV., Count of Toulouse, who was created Lord of Quercy in 972. Nearly on the level of the river is a cave half walled up, with traces of fresco on the walls, of course much later than the time of Taillefer. A modern house has been built on the platform that has been levelled, and much of the wall demolished; the upper fortified cave has an opening in the wall, pointed, of the thirteenth or fourteenth century. In much the same condition is another cliff castle in the rocks of the 


\section{CLIFF CASTLES}

valley of the Alzou, between Grammat and Rocamadour, a little above the cascade of the mill Du Saut.

I have elsewhere ${ }^{x}$ given an account of the curious castle of La Roche Lambert at Borne in Haute Loire, built in a basaltic cleft through which roars the river. It is the theatre of George Sand's novel, Jean de la Roche. "I may say without exaggeration that $I$ was reared in a rock. 'The castle of my fathers is strangely incrusted into an excavation in a wall of basalt 500 feet high. The base of this wall, with that face to face with it, identically the same rock, forms a narrow and sinuous valley, through which winds and leaps an inoffensive torrent in impetuous cascades. The Château de la Roche is a nest of troglodytes, inasmuch as the whole flank of the rock we occupy is riddled with holes and irregular chambers which tradition points out as the residence of ancient. savages, and which antiquaries do not hesitate to attribute to a prehistoric people.

"'The castle of my fathers is planted high up on a ledge of rock, but so that the conical roofs of the tower just reach above the level of the plain. My mother having poor health, and having no other place to walk save one tiny platform before the castle on the edge of the abyss, took it into her head to create for herself a garden at the summit of the crag on which we were perched midway."

In Cantal at Roqueville are the remains of a castle excavated out of the rocks. Between Jung-Bumzlau and BöhmLeipa in Bohemia is the rock-castle of Habichstein. Two lakes lie in a basin of the hills that are well-wooded up their sides, but have bare turfy crowns. The upper lake is studded with islands. Between this and the lower lake stands an extraordinary hump of sandstone, on a sloping tahus. 'This hump has much resemblance to a Noah's Ark stranded on a diminutive Ararat. 'The rock is perforated

1 "A Book of the Cevennes," Lond., J. Long.

152 


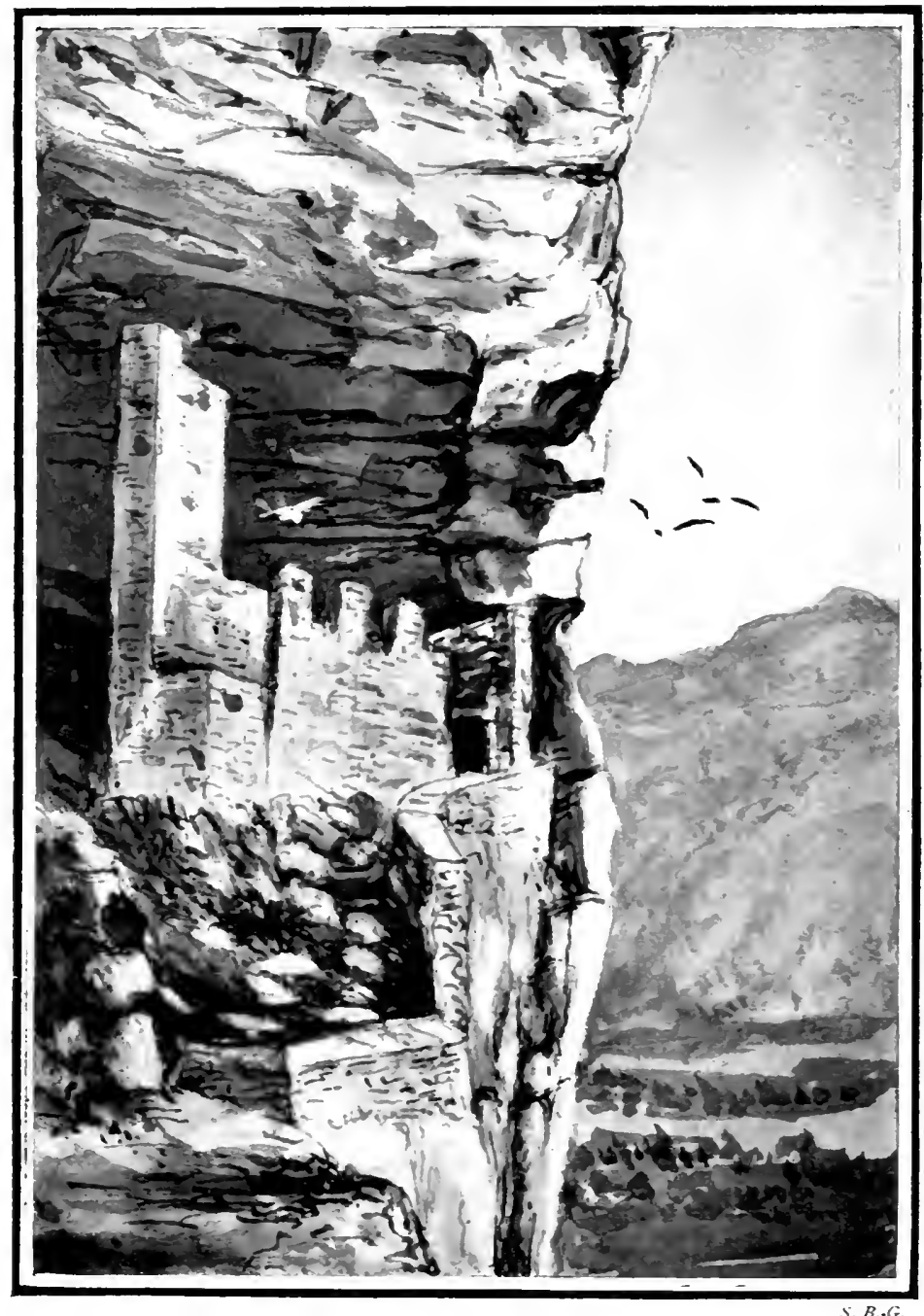

The Puxer Loch, Styria

Supposed to have been occupied by a sbadowless man. It was still inhabited. last century by an old mason. 



\section{CLIFF CASTLES}

in all directions with galleries and chambers, and contains a stable for horses and for cattle, which, howerer, is no longer accessible. On the summit of the rock rises a keep very nuch resembling a Pictish broch. Habichstein belongs to the Wallenstein family that possesses a stately schloss at the head of the upper lake. It has been abandoned for, probably, two hundred years, as it can never have been a comfortable residence; moreover, the sandstone is continually breaking away. Below the hill and castle is the village. In 1811 there was a fall of the rock, and again. in 1815, when it crushed three of the houses beneath.

Another and still more curious cliff castle in Bohemia is that of Burgstein. There are several on the frontier of the Wargau and the Hardt in North Bohemia, where the German and Czech languages meet, but it is not possible here to describe them all. Burgstein is the most curious. It consists of an isolated mass of sandstone springing out of level land, an outlying block of the Schwoik chain. Formerly it rose out of a lake or marsh, but this is now drained. The entrance is through a narrow gap in the rock by a flight of steps that lead into a court on all sides surrounded by sheer precipices except towards the North-west, where a gap was closed by a wall. Out of this court open caves, one was formerly the smithy, another the guard-room, a third the stable, and in a recess is the well. From the court access to the main structure is obtained by a rift in the sandstone commanded by the guard-room, and up which ascends a stair of 15 steps that leads to a second rift at right angles, up which leads a further stair of 76 steps, and from the landing $3 \tau$ descend to a lower portion of the rock, a platform with a breastwork of wall, important for defence of the entrance.

The steps lead to various chambers, and to an open court that looks out over the precipice, and has on one side scooped out of the rock a watchman's chamber, and on the 153 


\section{CLIFF CASTLES}

other an armoury, where pilasters on each side supported shelves on which helmets and breastplates were laid; and beyond this is a guard-room. The summit of the rock has on it a lantern that lights an underground chapel, and formerly contained a bell, also a modern summer-house. As the rock was commanded from the south by a spur of the Schwoik range, when cannon were introduced, a new mode of access was devised on the north side, a passage in loops was constructed leading to the upper court. The castle called in Czech, Stolpna, or the pillar, is first mentioned in the fourteenth century. 'The great highroad to and from Böhmisch-Leipa passed near it, and it became the stronghold of a Raubritter, Mikisch Passzer of Smoyn, who became such a terror to the neighbourhood that the Sixtowns league of Lausitz in 1444 attacked it with 9000 men, broke down the clam that held back the water, and made of the rock an islet in a lake and constrained Mikisch to surrender. Soon after, however, he recommenced his lawless proceedings, and was again attacked in 1445, and after a siege that lasted five weeks, forced to quit his fortress. At the end of the seventeenth century Burgstein was converted into a hermitage and Brother Constantine, the first hermit, either enlarged or dug out the present chapel and built the lantern above, through which it obtains light. He did more, he carved a figure of himself looking through a telescope, life size, and planted on the summit of the rock. On the occasion of the Prussian invasion of Bohemia the image was assumed to be a spy, and the Germans fired at it and greatly damaged the figure, and were much puzzled at being unable to prostrate the dauntless spy. The present possessor of the rock castle has had the figure restored. Burgstein remained the abode of a hermit till 1785, when the reforming Joseph II. abolished all hermitages, and turned out every hermit in his dominions. And now, back to the Jura limestone again. A few words must 154 


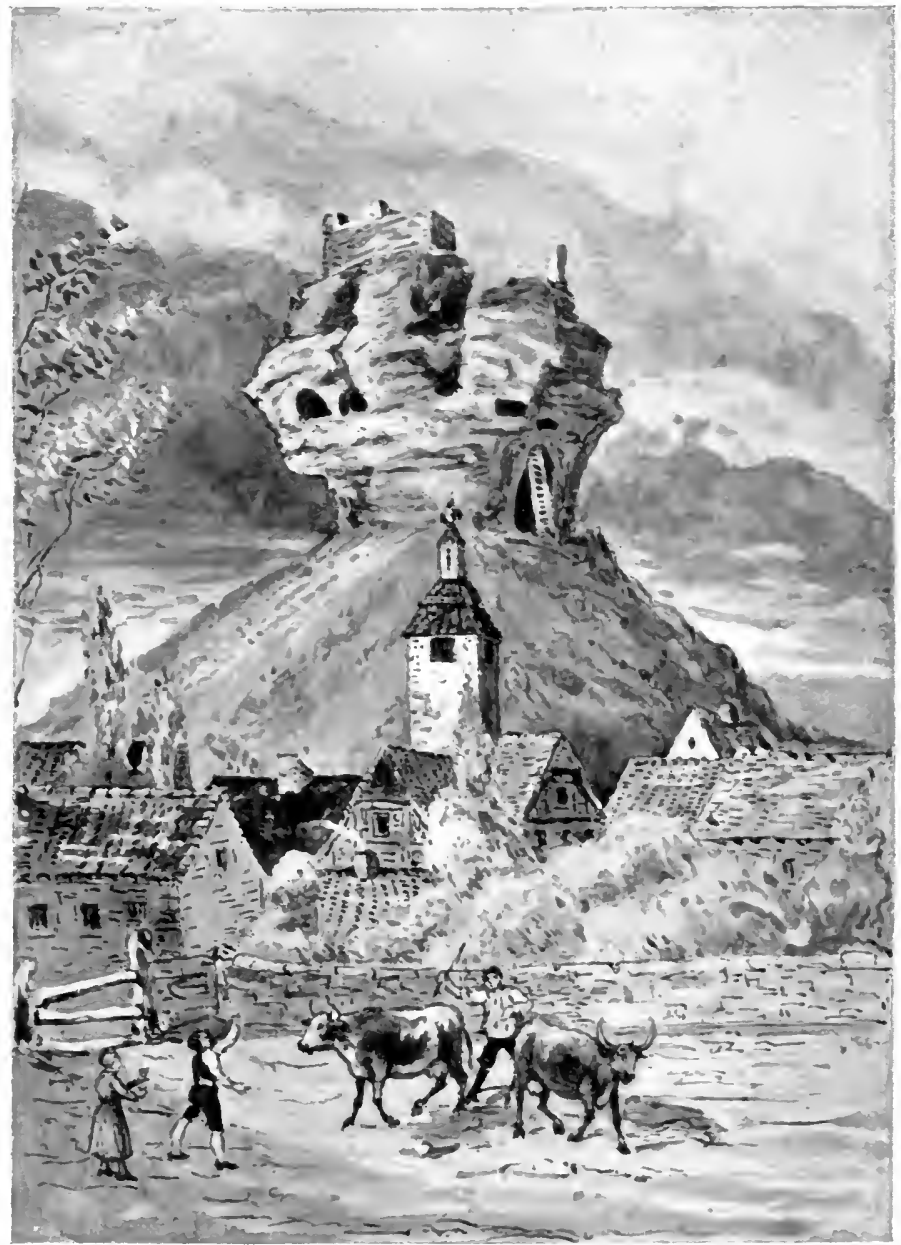

HabichSTEIN, BOHEMIA

S. B..G.

A castle belonging to Count Wallenstein, now abandoned owing to the falling away of portions of the rock. It contains stabes for horses and cattle, now inaccessible without ladders. 


$$
\text { - }
$$




\section{CLIFF CASTLES}

be given to Kronmetz in Tirol, at the month of the Val di Non, opening into the Etschthal.

This castle belonged to the Bishops of Trient, and was intended by them to serve as a place of "ward and custody" against invading or marauding bands.

But quis custodiet custodes? It was granted in fief to two brothers Von Leo, who turned it into a robbers' nest, so that the neighbourhood rose in arms in 1210 and stormed it. Then the bishops confided it to the Herren von Metz, and they carried on a feud with their orerlord, the bishop.

At last it came to the Counts von Firmian, who, in 1480 , built a more convenient mansion at the foot of the cliff, and turned the old castle into a hermitage.

The castle, that is in a fair condition, occupies a broad cleft in the rock, only accessible by a narrow path cut in the rocks on the west side. It consists of an outer court and an inner court, protected on the side of the precipice by a stout wall, behind which were originally chambers, as windows in the wall and beanholes show to have been the case. There is a doujon that reaches to the overhanging rock and a ruinous chapel with apsidal east end. The cleft runs further east, but is blocked with a wall.

Another cliff castle, of which Merian, in his Topographia, $1640-88$, gave a picture to arouse interest and wonder, is that of Covolo, at one time in 'Tirol, now over the Italian border. His description of it is as little accurate as his illustration. As a matter of fact, although it is certainly a cliff castle, constructed in a cave, it is accessible on foot, and it is by no means necessary to be conveyed to it by a windlass. Indeed it would not be easy to erect a crane on the platform of the castle that could haul up men and provisions from below.

A more famous fortress in a cave is that of Schallaun in the Puxerloch. Here is a grotto in the face of the precipice, 75 feet above the valley. The cliff itself is 4500 feet high. 


\section{CLIFF CASTLES}

The castle consists of two stages, the outer court is at a lower level than the face of the cliff, and the opening of the grotto. Entrance was obtained through this outer court that was rea'ched by a path cut in the rock, and from it by a stair also rock-hewn. A second court was reached, above this was again a third within the cave. On the right hand the cave branches out into a long inner cleft that was closed at one time by a door, and was probably used as a cellar. The main cavern also runs by a narrow passage deep into the heart of the rock to a pool of crystal clear water, never failing. The main building-hardly a donjon, was occupied till late in last century by an old mason who patched it up and made it habitable. At a little distance to the east is a smaller cave also with a wall in front of it, and this is said by the peasants to have been the kitchen of the castle, and to have been reached by a wooden gallery from the main building. According to tradition, Schallaun derives its name from Chalons. In the time of Charlemagne a knight of Chalons named Charlot eloped with a Saxon princess, and took refuge in this cave. It became a den of thieves, and Margaret Maultasch (Pouchmouth) took and dismantled it. According to another story the castle served as the haunt of a shadowless man. Unlike Camizzo's hero, he had not sold his shade to the devil, but by a lapse of nature had been born without one. This proved to him so distressing, and so completely interfered with his matrimonial prospects that he took refuge in the Puxerloch, where he was in shadow all day, and his peculiarity could not be noticed; he issued from it only on moonless nights, on one of which he carried off a peasant maid - and she never knew that he was shadowless, for he never allowed her to see his deficiency. Historically very little is known of the Schallaun castle, which is to its advantage, as when these castles are mentioned in chronicles, it is to record some deed of violence done by the occupants. In 1472 it belonged to the knightly family of 156 


\section{CLIFF CASTLES}

Sauran, but they sold it. It is now the possession of the Ritter von Franckh. ${ }^{I}$

Perhaps the nearest approach to the Puxerloch castle in France is the Roc de Cuze near Neussargues in Cantal. In the face of the cliff is a cave that has been converted into a castle, a wall closes the mouth, and there is a tower. Another fortress completely carved out of the rock is at Roqueville.

I will now deal with the third class, rock towns and castles combined. And I can afford space to treat of but one out of the many that would enter more or less into the category.

Although Nottingham town does not occupy the top of a rock, its castle that does cannot be passed by without notice, because that rock is perforated with galleries and has in it a subterranean chapel.

The castle, now bereft of its ancient splendour, of its coronet of towers, was built by William the Conqueror on the summit of a precipitous height rising above the river Leen. It was dismantled by Cromwell, and what remained was pulled down by the Duke of Newcastle, who erected on its site the uninteresting and unpicturesque mansion that now exists.

The castle was long considered impregnable; and to it Queen Isabel fled with Sir Roger Mortimer, whom she had created Earl of March, and she held it with a guard of one hundred and eighty knights. King Edward III. with a small retinue occupied the town. Every night the gates of the fortress were locked and the keys delivered to the Queen, who slept with them under her pillow. Sir William Montacute, with the sanction of the young king, summoned to his aid several nobles on whose fidelity he could depend,

1 In "Unser Vaterland, Steiermark," Stnttgart, n.d., p. 47, is a representation of the Puxerloch, but it resembles much more Kronmetz. It gives towers and walls and gates that do not exist in the Puxerloch. 


\section{CLIFF CAS'TLES}

and obtained Edward's warrant for the apprehension of the Earl of March. The plot was now ripe for execution. For a time, however, the inaccessible nature of the castle rock, and the vigilance with which the gates were guarded, appeared to present an insuperable obstacle to the accomplishment of their designs. However, Sir William Eland, Constable of the Castle, was won over, and he agreed to admit the conspirators. In the words of an old chronicler, the Constable said to Montacute, "Sir, woll ye unterstande that the yats (gates) of the castell both loken with lokys, and Queen Isabell sent hidder by night for the kayes thereof, and they be layde under the chemsell of her beddis-hede unto the morrow . . . but yet I know another weye by an aley that stretchith out of the ward, under the earthe into the castell, which aley Queen Isabell ne none of her meayne, ne the Mortimer, ne none of his companye knoweth it not, and so I shall lede ycu through the aley, and so ye shall come into the castell without spyes of any man that bith your enemies." On the night of October 19, 1340, Edward and his loyal associates before midnight were guided through the subterranean passage by Eland, and burst into the room where the Earl of March was engaged in council with the Bishop of Lincoln and others of his friends. Sir Hugh Trumpington, Steward of the Household, a creature of Mortimer, attempting to oppose their entrance, was slain. The Earl himself was seized, in spite of the entreaties of Isabel, who, hearing the tumult, rushed from her chamber, crying "Fair son, spare my gentle Mortimer!" Both were secured. The next day, Edward announced that he had assumed the government, and summoned a Parliament to meet at Westminster on the 26th November. No sooner had this Parliament met than a bill of impeachment was presented against Mortimer. 'The peers found all the charges brought against him to be "notorously true, known to them, and all the people." 


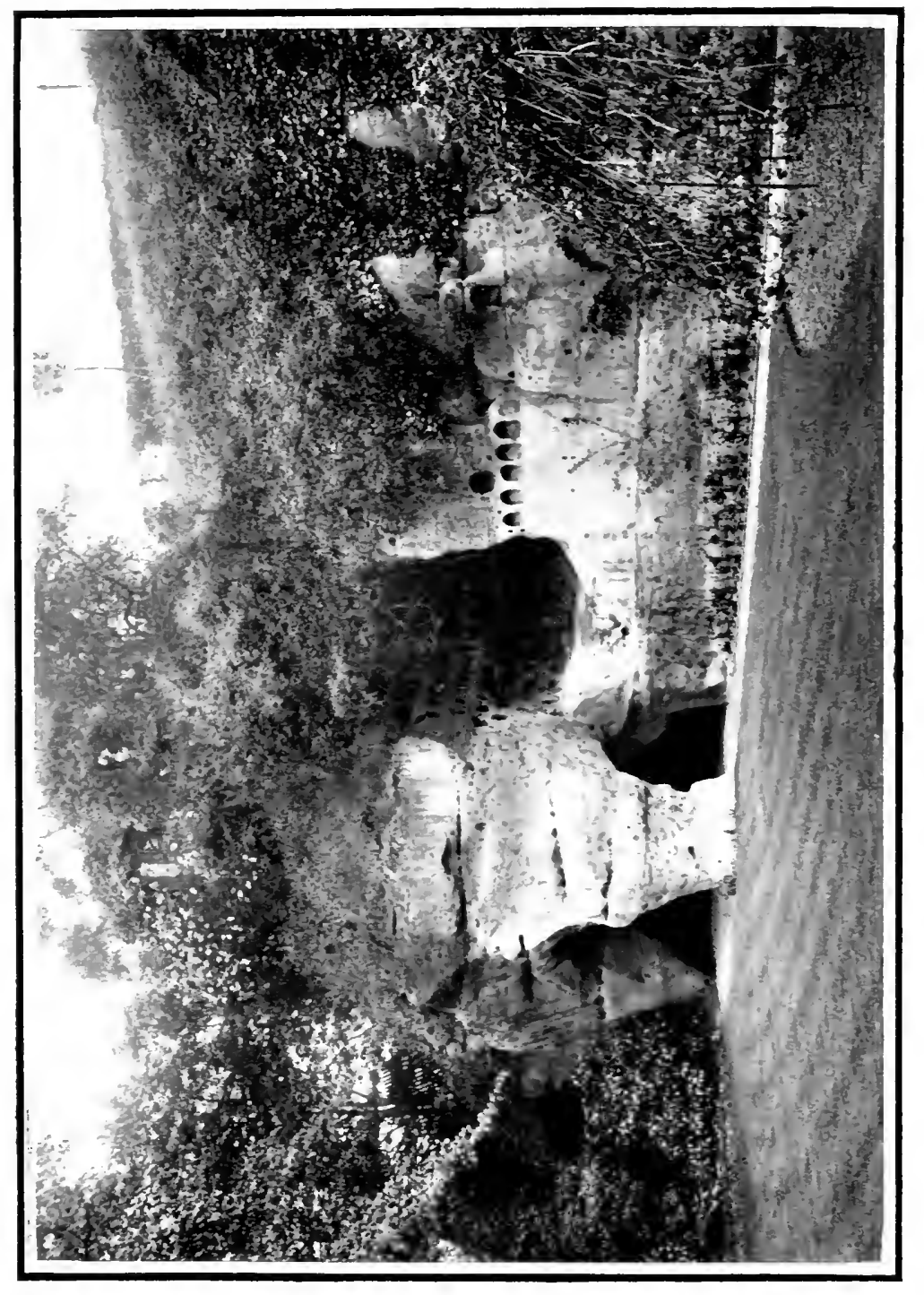

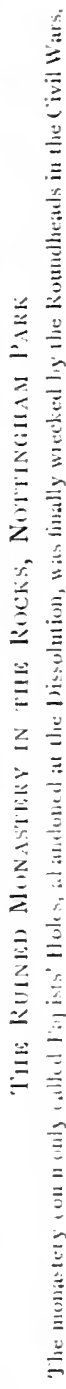





\section{CLIFF CASTLES}

And he was sentenced to be drawn and hanged as a traitor. Mortimer was executed at Tyburn, and the Queen Mother was sent under ward to the manor of Rising. The passage by which the conspirators entered, and by which the Earl was conveyed away, goes by the name of Mortimer's Hole to the present day.

If I were to attempt to deal with castles and towns on rocky heights I would have to fill pages with descriptions of Capdenac, Najarc, Minerve, Les Baux, San Marino, San Leo, and many another, but inasmuch as they are on rocks instead of being in rocks, I must pass them over.

A fourth class of cliff castle, neither the habitation of a routier nor the residence of a feudal seigneur, is that which commands an important ford, or the road or waterway to a town, and which was, in point of fact, an outpost of the garrison.

I can describe but a few.

The Emperor Honorius had conceded to the Visigoths all that portion of Gaul that lay between the Loire and the Pyrenees. The Visigoths were Arians. Far from imitating the Romans, who respected the religion of the vanquished, and cared only that the peoples annexed to the Empire should submit to their administrative and military organisation, the Visigoths sought to impose Arianism on the nations over whom they exercised dominion. The bishops and priests protested energetically against this tyranny, and the Visigoths sought to break their resistance by persecution and exile, but gained nothing thereby save bitter hostility. In the year 511 an erent took place that gave to the Aquitanians their religious liberty. 'The Franks were their deliverers.

Clovis, who coveted the rich provinces of the South, profited by the religious antagonism existing between the Aquitanians and the Goths to gain the confidence of the bishops to whom he promised the destruction of Arian 


\section{CLIFF CASTILES}

supremacy. And as he had obtained the strongest and most numerous adhesions in Poitou he resolved there to strike a decisive blow.

He prepared his expedition with such secrecy and moved with such celerity that Alaric II., King of the Visigoths, did not become aware of his peril till the army of Clovis was on the confines of his realm. He threw himself into Poitiers, and assembled all the forces he was able to call together. Clovis crossed the Loire at 'Tours, and directed his march towards Poitiers; he passed over the Creusse at Port de Pilles, and reached the Vienne. The season was the end of September, and there had been so much and such continuous rain that the river was swollen, and he could not cross. Accordingly he and his army ascended it on the right bank seeking for a ford.

He reached Chauvigny, where was a ford, but this was now found impracticable. On the left hand of the present road to Lussac-le-Chateau is a stony, narrow, waterless valley, up which formerly ran the old Roman highway. At the $2 \frac{1}{2}$ kilometre stone is a dense thicket of oak coppice, clothing the steep side of the valley. By scrambling down this, clinging to the oak-branches, one reaches a bluff of chalk rock, hollowed out by Nature at the foot to the depth of 10 feet, and running horizontally to the length of from 32 to 34 feet, and terminating in a natural barrier of rock. It contracts in one place so as to form two chambers. Now this gallery is closed towards the valley by a screen of six huge slabs 8 and 9 feet long, 8 and 9 feet high, and 4 feet thick. They have apparently been slung down from above, and caught and planted so as to wall up the open side of the recess. And at the north end another block, now broken, was set at right angles so as to half close the gallery at the end, leaving a doorway for access to the interior. The attempt to plant these huge slabs on a steep slope was not in every case successful, for a couple slid down the 160 


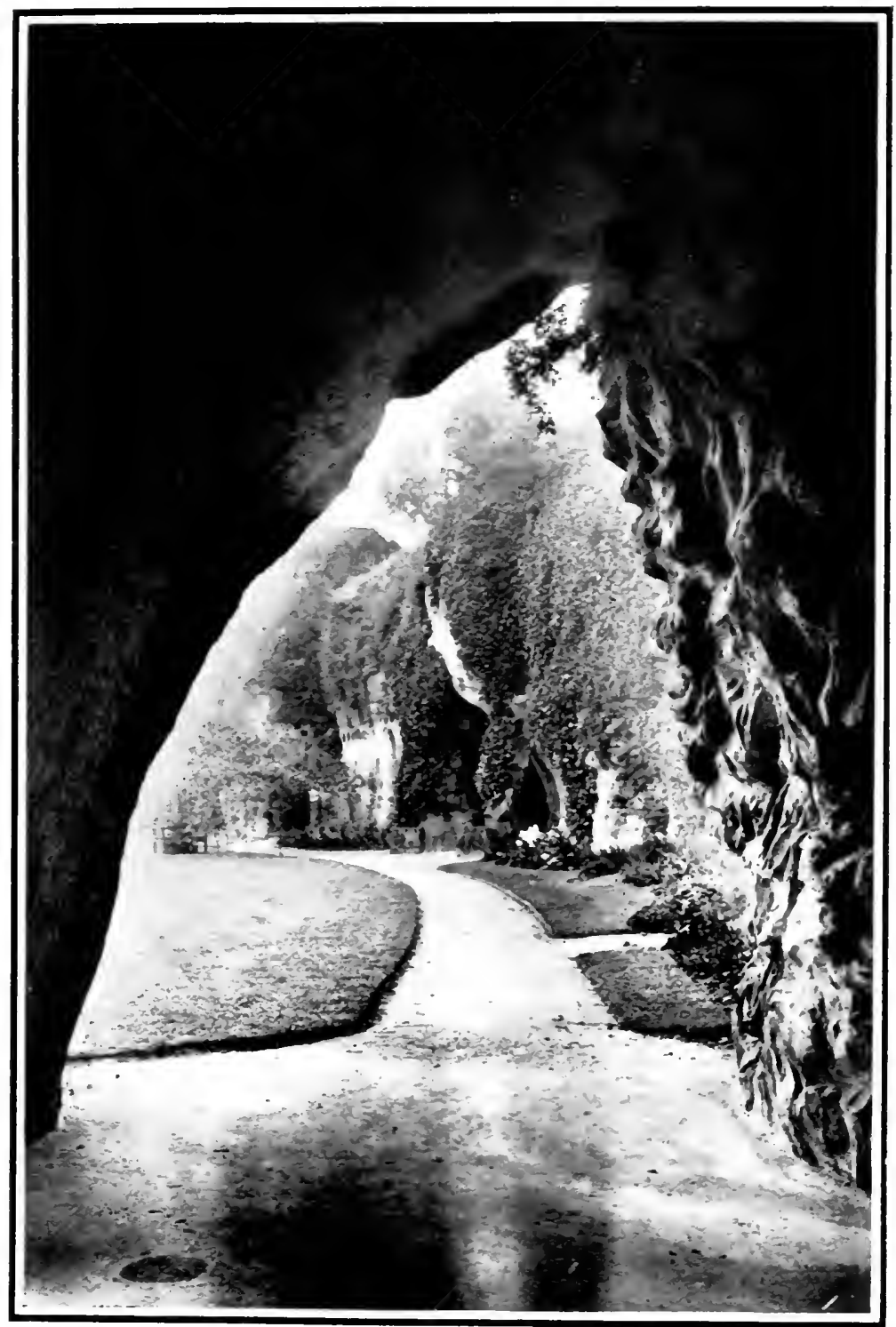

A Portion of the Rock Morastery, Nottingham Park 



\section{CLIFF CASTLES}

incline, but these served to form a heel-catch to those who did remain erect. Local antiquaries pronounce this to be a fortified cave, unique of its kind, devised to protect the road to Lussac, at the strategical point where it could best be defended. I have myself no manner of doubt that it was a so-called demi-dolmen, a tribal ossuary of neolithic man. Not only is it quite in character with his megalithic remains scattered over the country, but treasure-seekers who in digging displaced and brought down one of the side slabs found two diorite axes, one of which I was fortunate enough to secure. Persons in Gaulish or post-Roman times would not have dreamed of going to the enormous labour and attempting the difficult task of forming the sides with stone slabs, but would have closed the recess with a wall. The cave goes by the name of La Grotte de Jioux (of Jove) which in itselt hints its remote antiquity.

But, although I do not believe that this cave was constructed as a military vidette and guard-house, I have no doubt whatever that it may have been so used, and it is very probable that at this point took place the first brush of Clovis and his Franks with the enemy, for the valley bears the name of Le Vallon des Goths. Alaric knew, what Clovis did not, that there was a ford at Lussac, and if he had any military foresight, he would plant a body of men across the road in the throat of the valley to intercept the Franks on their way. As it was, the Franks pushed on, and seeing a deer wade across the river at Lussac, raised exultant shouts, plunged into the Vienne, and crossed. 'The result was the battle of Voulon, in which the Arian Goths were defeated, and their empire broken down. ${ }^{1}$ The Grotto of Jioux was but an accidental outpost, but those I

1 This decisive battle is located at Vonille to the north-west of Poitiers ; but local historians are convinced that the site was Voulon to the south of Poitiers. See Thibaudeau, Abrégé de l'Histoire de Poitou, Niort, 1889. 


\section{CLIFF CASTILS}

am about to describe were artificially contrived for that purpose.

In the broad valley of Le Loir below Vendôme, the great elevated chalk plateau of Beauce has been cut through, leaving precipitous white sides. At one point a buttress of rock has been thrown forward that dominates the road and also the ford over the river. Its importance was so obvious that it was seized upon in the Middle Ages and converted into a fortress. 'The place is called Le Gué du Loir. Not far off is the Château of Bonnaventure, where Antoine de Bourbon idled away his time drinking Surène wine, and carrying on an intrigue with a wench at le Gué, whilst his wife, Jeanne d'Albret, was sending gangs of bandits throughout her own and his territories to plunder, burn, and murder in the name of religion. But Antoine cared for none of these things. At Bonnaventure he composed the song:-

\footnotetext{
Si le roi m'avait donné

Paris, sa grande ville,

Et qu'il me fallait quiter

L'amour de ma mie,

Je dirai au roi Henri (III.)

Reprenez votre Paris,

J'aime mieux ma mie

Au Gué,

J'aime mieux ma mie.
}

Molière introduced a couplet of this lay into his Alceste.

'The rock has been excavated throughout, and in places built into, and on to. Two flights of steps cut in the cliff give access to the main portion of the castle. That on the right leads first of all to the Governor's room, hewn out of a projecting portion of the rock floored with tiles, with a good fireplace and a broad window, commanding the Loir and allowing the sun to flood the room. 'The opening for 


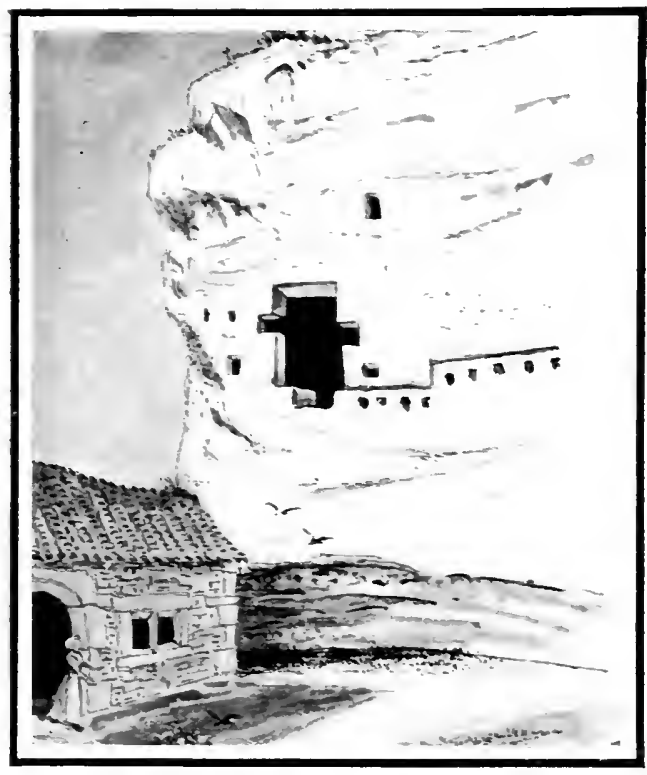

LA Roche CORAIL

S. B. G.

A cave fortress commanding the river Charante. The large opening is formed by brealing away a doorway and windows; the doorway communicated with a wooden balcony leading to other chambers in the rock.

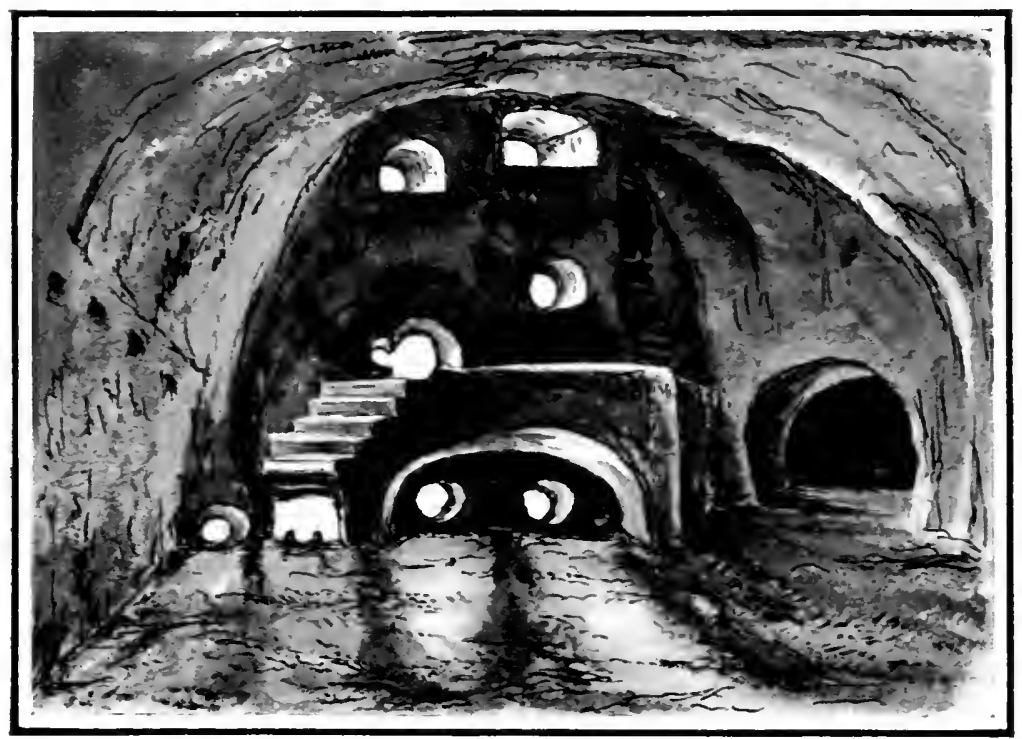

The First Hall. La Roche Corail.

Windows and slots for discharging missiles and for spearing those attempting to attack the garrison in its stronghold. 


\section{CLIFF CASTLES}

the window formerly contained a casement. There is a recess for a bed, and there are in the sides numerous cupboards and other excavations for various purposes. This chamber is entered through that of the sentinel, which was also furnished with a fireplace. The stair leads further up to a large hall artificially carved out of the chalk, but not wholly, for there had been originally a natural carern of small dimensions, which had a gaping opening. This opening had been walled up with battlements and loopholes, but the old woman to whom the rock or this portion of the rock belongs, and who is a cave-dweller at its foot, has demolished the wall to breast-height, so as to let the sun and air pour in, for she uses the cave as a drying place for her wash. From this hall or guard-room two staircases cut in the rock lead to other chambers also rock-hewn higher up.

The second main stair outside gires access to a second series of chambers.

Unfortunately, some rather lofty modern buildings have been erected in front of this cliff castle, so as to render it impossible to make of it an efiective sketch or to take a satisfactory photograph.

Still more interesting is La Roche Corail below Angoulême on the river Charente, opposite Nersac and the confluence of the Boeme with the Charente. Where is now a bridge was formerly a ford. The castle of Nersac commanded one side of the valley, and La Roche Corail the other. This cliff castle was at one time very extensive. 'The rock rises from a terrace partly natural and partly artificial, on which a comparatively modern château has been erected that masks the rock-face. But on entering the court behind the château the bare cliff is seen with a yawning opening halfway up, and indentations in the wall of rock show that at one time there were hanging barbacans and chambers suspended before the rock as well as others hewn out of it. 


\section{CLIFF CASTLES}

To reach the interior it is necessary to enter a grange that has been built at right angles to the rock, and in it to mount a ladder to another granary that occupies a floor of solid rock. Thence a second ladder leads into the caves. Formerly, however, the ascent was made by steps cut in the side of the cliff, and openings from within enabled the garrison with pikes to precipitate below any who were daring enough to venture up the steps uninvited.

'The ladder gives admission through a broken door cut in the rock into a long vaulted hall, that was formerly floored across so as to convert it into two storeys. ${ }^{1}$ 'The lower storey or basement opens on the left-hand side into a second cave, and the upper by a passage cut in the rock communicated with another range of chambers looking out of the face of the crag by artificial windows. Immediately in front of one entering the hall is the portal of admission to another very large hall that had originally well-shaped windows, and a door leading on to the wooden balcony, but this has all been broken away forming the ragged opening seen from below.

In 1534 Calvin was staying in the adjoining parish of S. Saturnin with a canon of the cathedral of Angoulême, who had a good library, and was disposed to favour him. The house is pointed out, but it has been rebuilt or altered. A cavern there is also shown to which Calvin retired to meditate on his Reform. It is now a cellar full of casks, wheelbarrows, and rubbish. It was never a very pleasing resort, and he preferred to come to La Roche Corail where, in the cavern just described, he had more space, and less likelihood of being disturbed. And here it was that he wrote his "Institute of the Christian Religion." One is disposed to rest here for awhile and muse, and consider

1 Actually the doorway and three lower openings look into the dark granary. In the illustration I bave shown them as letting light in, as intended originally. 


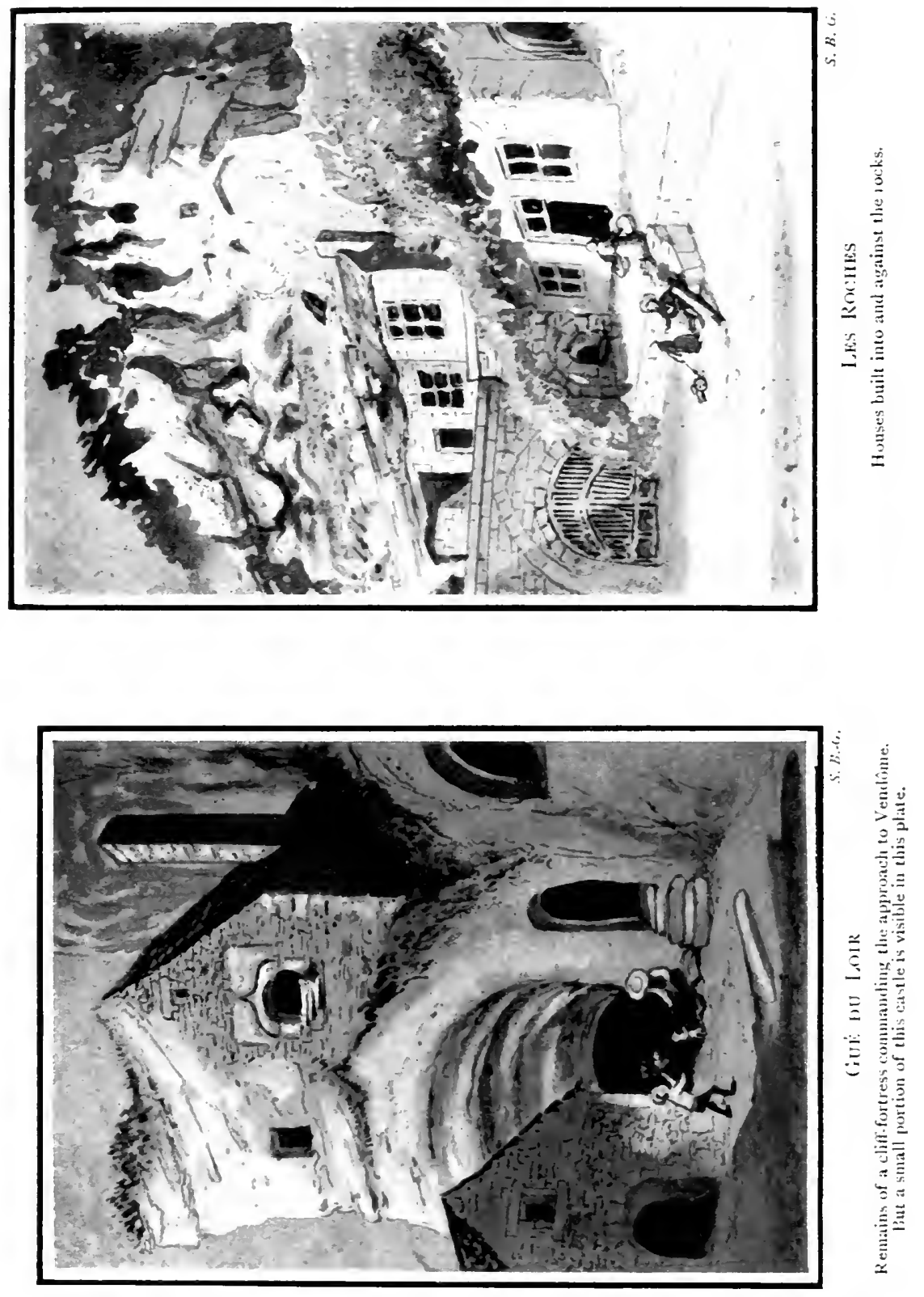




\section{CLIFF CASTLES}

what a manufactory of explosives this carern was. From this raulted chamber was launched that doctrine which was to wreck nearly every church in France and drench the soil in blood. I do not in the least suppose that Calvin saw any beauty in the view through the gap in the rock-not in the island below with its poplars and willows whose branches trail in the bottle-green waters of the Charentenot in the lush meadows with the yellow flags fluttering by the waterside-not in the grey towers of Nersac castle and church rising above dark woods, flushed orange in the setting sun against a purple sky. I do not suppose that he noticed the scent of the wallflowers growing out of every fissure wafted in on the summer air. There was logic thought in his head, but no poetry in his heart, no sweetness in his soul. He looked across in the direction of Angoulême, and wished he had a ladder and a hammer that he might smash the serene face of the Saviour looking down on the city from the western gable of the cathedral. Five and twenty years must elapse before that wondrous domed pile was to be wrecked by the Huguenots, his disciples. But here it was, in this cavern, that he elaborated his system of reform, treating Christianity as a French peasant treats an oak tree, pollarding it, and lopping off every lateral, natural outgrowth. Assuredly, many a volatile superstition had lodged in its branches, and many a gross abuse couched under its shadow. But these might have been scared away without mutilating the tree till it was reduced to a stump. He desired, doubtless, to bring back the Church to the condition in which he supposed it had been when born. But one cannot reduce an adult to the simplicity and innocence of childhood by stripping off all his clothes, and denying him the conventional figleaf.

Having shattered the Catholic faith by the crowbar of his logic, he sought to build up a grotto out of its fragments, 165 


\section{CLIFF CASTLES}

and call it a church. His "Institute of the Christian Religion" was published the following year. It produced the desired effect at once. 'There were many reasons why it should. Earnest and devout souls were troubled at the sight of a Christianity that was so in name but had little Christianity in its practice. They felt that the Church had drifted far out of its way and had grounded on quicksands, and they thought that the sole way of saving the hulk was to cast all its precious lading into the sea. Christ's Church had been founded on a rock, it had withstood the rain and the flood, but was crumbling down with dry rot. Calvin would have neither the rock nor the sand. Into the mud he drove the piles by the strokes of his genius, on which to erect the platform that was to uphold the conventicle of his followers, and if that did not stand, it would at least mark its site by their dejections. And dejections there are everywhere, where the Calvinists were, wrecked churches, mutilated monuments, broken glass, and shattered sculpture. Ruskin, remarking on some delicate carving at Lyons, under a pedestal, observes that the mediaval sculptors exhibited absolute confidence in the public, in placing their tenderest work within reach of a schoolboy's hand. Such, however, was the love of the beautiful generally diffused, that objects of art were safe from destruction or defacement. But with the outburst of Calvinism all those affected were inflamed with a positive hatred of the beautiful in art. If this had been confined to the destruction of images to which idolatrous worship was offered, it would be explicable and justifiable, but it extended to the most innocuous objects. Delicate tracery such as adorns the west front of the church of Vendôme, a lace-work of beautiful sculpture representing trailing roses and vines, birds and reptiles, was ruthlessly hacked. Churches, cathedrals, were blown up with gunpowder-such was the fate of the cathedrals of Montauban, Périgueux, and Orléans. Beza himself rolled the barrels of 166 


\section{CLIFF CASTLES}

gunpowder to explode under the great piers that sustained the central tower of Orleans. ${ }^{1}$

The cry for reform was loud, and rang from every quarter of Europe except from the Vatican, where the Pope, like Dame Partington with her mop, thought to stay its progress. The grandsons of the old routiers cried fie on this quiet life, and snuffed the air for rapine. The nobility were out of pocket and out at elbows, and looked with avaricious eyes on the fair and broad lands of the Church, and their fingers itched to be groping in her treasury, and they hoped to patch their jerkins with her costly vestments. 'Court favourites were abbots in commendam, held prebendaries, without being in holy orders, sixfold pluralists abounded, ecclesiastical hippopotami, that might fairly be hunted. All kinds of interests were enlisted against the Church, good and bad, sincere and hypocritical, only a spokesman was needed, a trumpet sound to call to the battle, and Calvin proved the spokesman, and his "Institute" was the trumpet note.

An outpost station that is curious and puzzling is La Rochebrune on the Dronne, below Brantôme. The road to Bourdeilles and Périgueux runs immediately below a chain of very fine chalk cliffs, and there is but just space for it between the steep slope below them and the river. At one point about a mile and a half below Brantome, the cliff is broken through, where a lateral valley opens on that of the Dronne : here there is a talus overgrown with box and juniper leading up to a rock, of inconsiderable height, with some holes in it, overhanging, and capped with brushwood that at one time also covered the slope below the rock.

By the roadside, immediately under this rock, is the opening into a cave that admits into another much larger,

1 In 1769 Montgomery was preparing to blow up the beautiful Cathedral of Condon, only consecrated thirty-eight years before, but accepted as its ransom from the inhabitants the sum of 30,000 livres. 


\section{CLIFF CAS'TLES}

and lighted from above, and in which at the extremity is a passage leading upwards, now choked with earth and stone.

The original entrance to the cave has been destroyed through the widening of the highroad, so that it is now impossible to tell whether it was effectually concealed or whether precautions had been taken for its defence.

At one spot only in the rocks above is there a gap, and through that gap, probably once walled up, access is obtained into a sort of circular courtyard, where there are traces of a fireplace, and where is a stone bench. From this court a spiral staircase, rock-hewn, leads to the platform on top of the rocks. In the wall on the right of the court is a doorway neatly cut in the chalk, square-headed and adapted for a framed door that could be strongly barricaded. Immediately within is a quadrangular pit sunk in the floor, now choked with stones. This, in such a position, could not be a silo, it probably was the opening through which those who entered the cave from below, by the road, made their way into the interior of the fortress. Stepping over this pit one enters a hall with six large round holes cut in the roof communicating with an upper chamber, and receiving a borrowed light through them. A spiral staircase at the side furnished with meurtrieres through which the besieged could stab at their enemies, leads to the upper hall or chamber, which is lighted by two rude windows, one high up, the other low down, and with a bench recess opposite them. But the strange and perplexing feature of this room is that it has in the floor eight round holes, each large enough to let a man fall through. Six communicate with the chamber below, but the other two open under the overhanging cornice, outside the castle. One of the holes-opening into the nether chamber, is precisely where would rest the feet of men seated on the bench. There is no trace of a groove to receive covers to these holes.

It has been conjectured that this strange construction 168 


\section{CLIFF CASTLES}

was a granary, in which the peasants concealed their corn ; but there are difficulties in accepting this theory. The Rochebrune commands the road, and a hiding place would assuredly be located in the depths of a wood, away from a highroad, in some secluded valley. It has been conjectured that the holes served for discharging the corn into the lower chamber. But why carry it by a narrow winding stair aloft to pour it down into a nether cave, when the latter, the supposed granary, itself was at once accessible through the doorway? Moreover, two of the holes open outwards, and not into the supposed store-chamber. It may be said that these were for hauling up the sacks of corn, but the incline on which they open is so steep, that it would be a prodigious waste of labour to drag the corn up under the cornice in which they are, whereas the other ascent is easy. The precautions taken to provide means of stabbing at an assailant point to this having been a fortress. My interpretation of the puzzle is this: first, that the left hand stair leading to the summit of the crag enabled one of the defenders to light a beacon, so as to warn the people of Brantôme when danger threatened; that next, the garrison, which could not have comprised more than five or six men, as Rochebrume is very small, retired within the rock. If this courtyard were invaded, they escaped into the lower chamber and barred the door, and were able to thrust at assailants through the slots. But if the door yielded they would scramble up the rock stair into the upper apartment, and as the enemy broke into the lower cavern, they stabbed and thrust at them through the six holes in the floor. Should their position be rendered untenable, they could slip through the two holes that opened outwards, into the brushwood and so effect their escape; for these holes would not be perceived, or their purpose understood by besiegers unfamiliar with the castle.

Usually, over the floor, riddled like a colander, planks 169 


\section{CLIFF CAS'TLES}

were laid, that on emergency could be turned up on their sides. I may add that the windows opening outwards are purposely so inartificially made that no one passing along the road underneath would suspect that there was a fortress above his head. He would certainly suppose that these holes were natural, such as are commonly found in the chalk cliffs. In fact the first time I visited Brantôme, and walked down the river to Bourdeilles, I passed this rock and entertained no suspicion that it contained anything remarkable, that it was as a matter of fact, a mere shell, with all the artificial work within.

Why was it that every city-nay, every little townhad to be not only walled about but to have its outposts? Because France was not a nation, only a congeries of individualities. As Michelet says of the fourteenth century : "The kingdom was powerless, dying, losing self-consciousness, prostrate as a corpse. Gangrene had set in, maggots swarmed, I mean the brigands, English and Navarese. All this rottenness isolated, detached the members of the poor body from one another. One talks of the Kingdom, but there were no States General, nothing at all general, no intercommunication, the roads were in the power of cutthroats. The fields were all battlefields, war was everywhere, and none could distinguish friend from foe."

How needful these outposts were may be judged from what Froissart says: "Rogues took advantage of such times (of truce), and robbed both towns and castles; so that some of them, becoming rich, constituted themselves captains of bands of thieves; there were among them those worth forty thousand crowns. Their method was to mark out particular towns or castles, a day or two's journey from each other; then they collected twenty or thirty robbers, and travelling through by-roads in the night-time, about daybreak entered the town or castle they had fixed upon, and set one of the houses on fire. When the inhabitants 


\section{CLIFF CASTLES}

perceived it they thought it had been a body of soldiers sent to destroy them, and took to their heels as fast as they could" (Bk. i., c. 147).

Passing on from the outposts to towns, or defences to highways, we must glance at such as guard the approaches to countries, or such as Gibraltar that commands the great waterway between the Mediterranean and the Atlantic. Gibraltar is certainly the most complete and marvellous of all cliff castles. This is too well known to English travellers to need description here.

The French Gibraltar, Urdos, commands one of the passes through the Pyrenees. It is hewn out of the mountain in a buttress of rock, and rises in stages from the road to the height of $\mathbf{5 0 0}$ feet. Externally the mountain looks harmless enough. A cave opens here, and a rift there, and a few streaks of masonry may be noticed, but actually the mountain is riddled with galleries, batteries, and long flights of stairs, and hollowed out for ammunition and other stores; and it is capable of containing a garrison of three thousand men.

Faron also, 1660 feet high, with its magnificent precipices of salmon-coloured limestone, commanding both the harbour of Toulon and the Bay of Hyères, is capped with fortifications and pierced with batteries, casemates, and chambers for military stores, a position made by Nature and utilised with supreme skill. Nor must the chain of rock-forts of Campi delle Alte and of Mont Agel above Monaco, dominating the Corniche road be forgotten, ready to drop bombs amidst an army from Italy venturing along that splendid road, nor must Besançon be forgotten, occupying its inaccessible rock-inaccessible that is, to an enemy.

"Oppidum maximum Sequanorum," as Casar described it in his day; "natura loci sic muniebatur ut magnam ad ducendum bellum daret facultatem."

Ehrenbreitstein faces the opening of the Moselle into the 171 


\section{CLIFF CAS'TLES}

Rhine; and Frankenfeste holds the key of the Brennerpass; and Dover Castle commands the strait at its narrowest. Königstein crowning a precipitous rock 748 feet above the Elbe, though in Saxony is garrisoned by Prussians, guards the pass down the river from Bohemia; and Peterwardein is a rock-built fortress, that has been called the Ehrenbreitstein and Gibraltar of the Danube. What are these frontier fortresses but the same on an extensive scale as the Gué du Loir, the Roche Corail, and the Rochebrune? In the Middle Ages every city, every little town had to have its outposts and watch-tower on the look-out for the enemy, and to break the first impetus of an attack. But now it is not the town but the nation that has to gird itself about with frontier fortresses. 


\section{CHAP'TER VII}

\section{SUBTERRANEAN CHURCHES}

T THEN the period! of persecution of the early Christians had come to an end, and they were able in security to assemble for worship, two distinct types of Church contested for the supremacythe Basilican and the Catacumbal.

Even during the times before Constantine, when persecution was in abeyance, Christians had been accustomed to gather together for the Divine mysteries in private houses. But after that Christianity was recognised and faroured, the wealthy and noble citizens of Rome, Italy, and Africa, who had become Christians, made over their stately reception halls, or basilicas, to be converted into churches. 'These basilicas, attached to most palaces, were halls comprising usually a nave with side aisles separated from the nave by ranges of columns, and an apse at the extremity of the nave in which the master of the house was wont to sit to receive his clients and his guests. This is the type upon which cathedral and parish churches in east and west are modelled. But the early Christians had become accustomed in times of danger to resort to the subterranean chapels in the Catacombs. The poorer members doubtless preferred these dingy meeting-places to the lordly halls of the nobles, and the slaves could not feel their equality with their masters under the same roof where they had served, and been whipped, as in the Catacombs, where all were one in fear of their lives and in the darkness that buried distinction. Moreover, the 


\section{SUBTERRANEAN CHURCHES}

cult of the martyrs had grown to a passion, and it had become customary to commemorate their nativities as it was called, i.e. the anniversaries of their deaths, at their tombs in the Catacombs. It was there that the faithful habitually prayed, it was near the bones of the Saints that it was believed special sanctity dwelt, and that prayers were most effectually answered through their intercession; and it was there, ad martyres, that they themselves purposed to be laid in expectation of the Resurrection.

In Rome, the tombs of the martyrs continued to enjoy popular favour, and to attract crowds, till the incursion of the Lombards, when, to save the relics of the Saints from profanation, they were transferred to the basilicas within the walls, whereupon the Catacombs ceased to interest the faithful, that were neglected and allowed to fall into oblivion. Gaul rejoiced in having had its soil watered with the blood of many witnesses to the Faith, consequently it had numerous hypogee chapels, and when, to the Martyrs were added hermits, abbots, bishops, devout women, and confessor's of all descriptions, their underground tombs became extraordinarily numerous, and were resorted to with great devotion. Such was the origin of the crypts found in profusion in France, not under cathedrals only, but under parish and monastic churches as well. The whole population having become Christian, the resort to these subterranean chapels became so great as to cause inconvenience, and the bishops proceeder to "elevate" "illate" and "translate" the bones of the saints from their original resting-places to the basilicas above ground. Thereupon the crypts lost most of their attraction, and the worshippers gathered about the altars in the upper churches to which the bones had been transferred.

In Britain, where there were no early martyrs save Alban at Verulam, and Julius and Aaron at Caerleon, the type of church from the beginning was basilican, as we may see 174 


\section{SUB'TERRANEAN CHURCHES}

by that unearthed at Silchester, and that of S. Martin at Canterbury.

It was the same in Germany and throughout Northern Europe.

John and Paul were chamberlains to the Princess Constantia. They had in some way incurred the anger of the Emperor Julian, and he sent orders for their despatch in their own house on the Coelian hill. They were accordingly executed in their bath, and were buried in the cellar under their mansion. At once a rush of the devout of Rome took place to the Coelian to invoke the aid of these new martyrs. The visitors picked off the plaster, scribbled their names on the walls, applied kerchiefs to the tomb, and collected the dust, stained with the blood of the chamberlains. Pope Hadrian IV., 1158, built a basilica on top of the house, driving the foundations through it, and transferred to this upper church the bones of SS. John and Paul. At once the stream of devotion was deflected from the substructure to the superstructure, and the former was filled up with earth and totally abandoned.

Herbert Spencer has established in his "Principles of Sociology" that the mausoleun was the egg out of which the temple was evolved. 'The first cave-dwellers buried their dead in the grottoes in which they had lived, and themselves moved into others. They periodically revisited the sepulchres to bring offerings to the dead. In time the deceased ancestor became invested by the imagination of his descendants with supernatural powers, and ascended from stage to stage till he was exalted into a deity. Thenceforth his cave became a temple. Ferguson, writing of the Chaldæan temples, and indicating their resemblance to tombs says, "The most celebrated example of this form is as often called (by ancient writers) the tomb or the temple of Belus, and among a Turanian people the tomb 


\section{SUBTERRANEAN CHURCHES}

and the temple may be considered as one and the same thing." 1

In the primitive Church there were, as we have seen, churches which had no connection whatever with sepulchres, and chapels underground that contained tombs. The current of popular feeling set so strongly towards the latter that the Popes yielded to it, as did also the Bishops, and converted every basilica into a mausoleum by the transfer to it of the bones of a saint.

But that was not all. The Holy Mysteries had been celebrated in private houses and basilicas on wooden tables, sometimes square, but often round, and with three legs. An illustration is in the cemetery of S. Calixtus, of the latter half of the second century, where a priest is represented celebrating at what looks like a modern tea-table. According to William of Malmesbury, S. Wulstan, Bishop of Worcester (1062-1095), destroyed the wooden altars in his diocese, which had been universal in England, altarea lignea jam inde a priscis diebus in Anglia. But with the transformation of the basilica into a mausoleum, the altar was also transformed into a sepulchre. If it did not contain the entire body of a saint, it had a hole cut in it to receive a box containing relics; and the Roman pontifical and liturgy were altered in accordance with this. The Bishop on consecrating an altar was to exact that it should contain relics, and the priest on approaching it was required to invoke the saints whose bones were stored in it. 'The cavity in the slab to contain

I Clement of Alexandria (Exhort. to the Heathen) had already said, "Temples were originally Tombs." Cf: also Eusebius (Præp. Evangelica ii. 6) heads the chapter, "The Temples of the Gods that are none other than Tombs."

2 Pontifex accepta mitra, intigit policem dextræ manus in sanctum Chrisma et cum eo signat confessionem, id est sepulchrum altaris, in quo reliquir deponendx. Pont. Roman. The priest on ascending to the altar kisses it, and refers to the relics contained in it. "Oramus te, Domine, per merita sanctorum tuorum quorum reliquiæ hic sunt-ut indulgere digneris omnia peccata mea." 


\section{SUBTERRANEAN CHURCHES}

the relics was liturgically entitled sepulchrum. The change from a table to a tomb involved a change of material from wood to stone.

The dedication of a church to a saint in the Latin Church implies the presence in the sepulchre of the altar of the relics of that saint. From the Roman point of view, a dedication without the relic is unmeaning. Among the Celts this was unknown, with them a church took its name after its founder, and the founder of a church dedicated it by a partial fast of forty days, and prayer and vigil on the spot. The early basilicas of Rome also took their titles from the families that surrendered their halls for Christian worship. The introduction of dedication to deceased saints marks unmistakably the transformation of a church from a basilica to a mausoleun.

It is certainly remarkable that whereas in Paganism the identification of the tomb with the temple passed away, and the temple acquired independence of such association, in the Latin Church the reverse took place; there the church unassociated with a tomb-a basilica in fact-was converted into a sepulchral monument.

The reverence of the early pontiffs shrank from dismembering the bodies of the saints. To Queen 'Theodelinda Pope Gregory I. would accord only oil that had burnt in the lamps at their tombs, or ribbons that had touched them. Gregory V., in 594, wrote to Constantia Augusta, who had built a church in honour of S. Paul, and craved a portion of his body: "Dear lady, know that the Romans when they give relics of the saints are not accustomed to parcel up their bodies, they send no more than a veil that has touched them." 1

But when the Latin Church was constrained by the force of popular prejudice to transform all her sacred temples into sepulchral churches, there was no help for it; the bodies of

1 Baronius, Hiérothonie de J. C., Paris, 1630, p. 173.

$1 \%$ 


\section{SUB'TERRANEAN CHURCHES}

the saints had to be torn in pieces for distribution. A toe, a finger was taken off, legs and arms were amputated, the vertebræ of the spine were dispersed over Christendom, the teeth were wrenched out of the jaws, the hair plucked from head and chin, moisture exuding from the body was carefully cherished, and bones were rasped to furnish a little sacred phosphate of lime to some church clamorous to be consecrated.

A plateau to the south of Poitiers had long borne the name of Chiron Martyrs. Chiron means a heap of stones, but why the epithet of Martyrs attached to the heaps of stones there nobody knew. The old Roman road leading to and athwart it was named La Route des Martyrs, also for no known reason. But in October 1878 the plateau was being levelled by the military authorities, when it was discovered that the stones were actually broken tombs, and that they were clearing a pagan, Necropolis. Soon they came on a portion where were sarcophagi orientated and crowded thickly about a subterranean building. The distinguished antiquary, Le Père de la Croix, now undertook the investigation, and discovered that these latter were the tombs of Christians, and that they surrounded a hypogee Martyrium. This was excavated and proved to be a chapel erected over the bodies of certain martyr's of Poitiers, of whom no records had been preserved, or at all events remained, whose very existence was unknown; also, that it had been constructed by an abbot Mellebaudes at the end of the sixth or beginning of the seventh century. It contained an altar built up of stone, plastered over and painted, measuring at the base 2 feet $8 \frac{1}{2}$ inches by 2 feet 2 inches and 3 feet 7 inches high. Also sarcophagi for the bodies of the martyrs there found, also one that Mellebaudes had prepared for himself. In the floor were many graves, possibly of his kinsfolk. Numerous inscriptions in barbarous Latin, some paintings and carvings, were also found. Among the latter 


\section{SUBTERRANEAN CHURCHES}

a rude sculpture represented two of the martyrs, Hilarius and Sosthenes, who had been crucified. A bracelet of amber

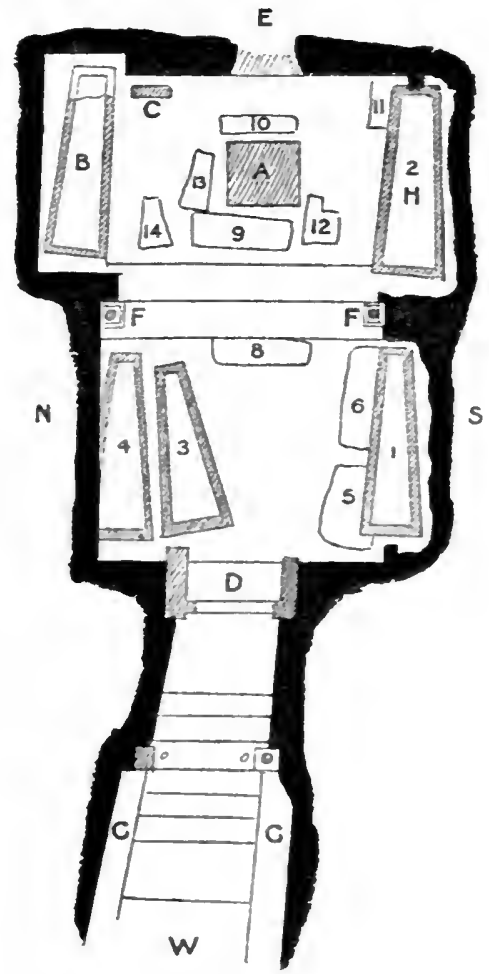

Plan of the Martyrium.

1-4. Stone sarcophagi.

$5,6,9,10,14$. Graves sunk in the rock, covered with flat slabs, containing bones.

8. Pit covered with a carved slab.

11, 13. Children's graves covered with carved slabs brought from elsewhere. 12. Pit contsining no bones.
A. Altar.

B. Arcosolium containing the sarco. phagus with the bones of the martyrs.

C. The sculpture of the crucified saints.

D. Doorway.

F.F. Pilasters.

0.O. Broken pilasters.

G.G. Benches.

H. Sarcophagus of Mellebsudes.

E. East window.

and coloured glass beads, amber ear-rings, and bronze ornaments were also discovered. 


\section{SUB'TERRANEAN CHURCHES}

Mellebaudes certainly built his mausoleum where there had been one earlier, that had become completely ruinous, for he complains that he had not been able to recover all the bones of the martyrs that had been laid in it. This destruction had probably been effected by the Visigoths, and the building by Mellebaudes took place some time after the defeat and expulsion of these Arians in 507. 'The final ruin of the Martyrium he raised may have been the work of the Saracens in 732. ${ }^{1}$

The hypogee was sunk nine feet in the rock, but the roof must have shown above ground. A window was to the east. S. Avitus in the sixth century speaks of the wondrous skill of architects in his day, who contrived to introduce daylight into the crypts. It is evident that no glass was inserted in the window, although the use of glass for windows was becoming general in the sixth century; and Fortunatus, Bishop of Poitiers, died 609, and Gregory, Bishop of Tours, died 595, both speak in terms of admiration of the glazing of windows for churches. It may well be understood that in the mind of the people long after the stream of public devotion had been directed to the churches above ground, a liking for those that are excavated underground should remain. Indeed, it is not extinct yet, as any one may see who visits the church of Ste. Croix at Poitiers, or S. Eutrope at Saintes, or S. Martin at Tours, to mention but three out of many. In all these are mere empty tombs, yet they are the resort of numerous devotees. 'The darkness, the mystery of these subterranean sanctuaries, impressed the imagination. Accordingly we find, especially in France, many cave-churches. Indeed they are so numerous that I can afford space to describe but a couple of the largest. Many are small, mere chapels, and shall be dealt with under the heading of hermitages.

1 For full account with plates see P. Oamille de la Croix, S. J. Hypogée Martyrium de Poitiers, Paris, 1883. 


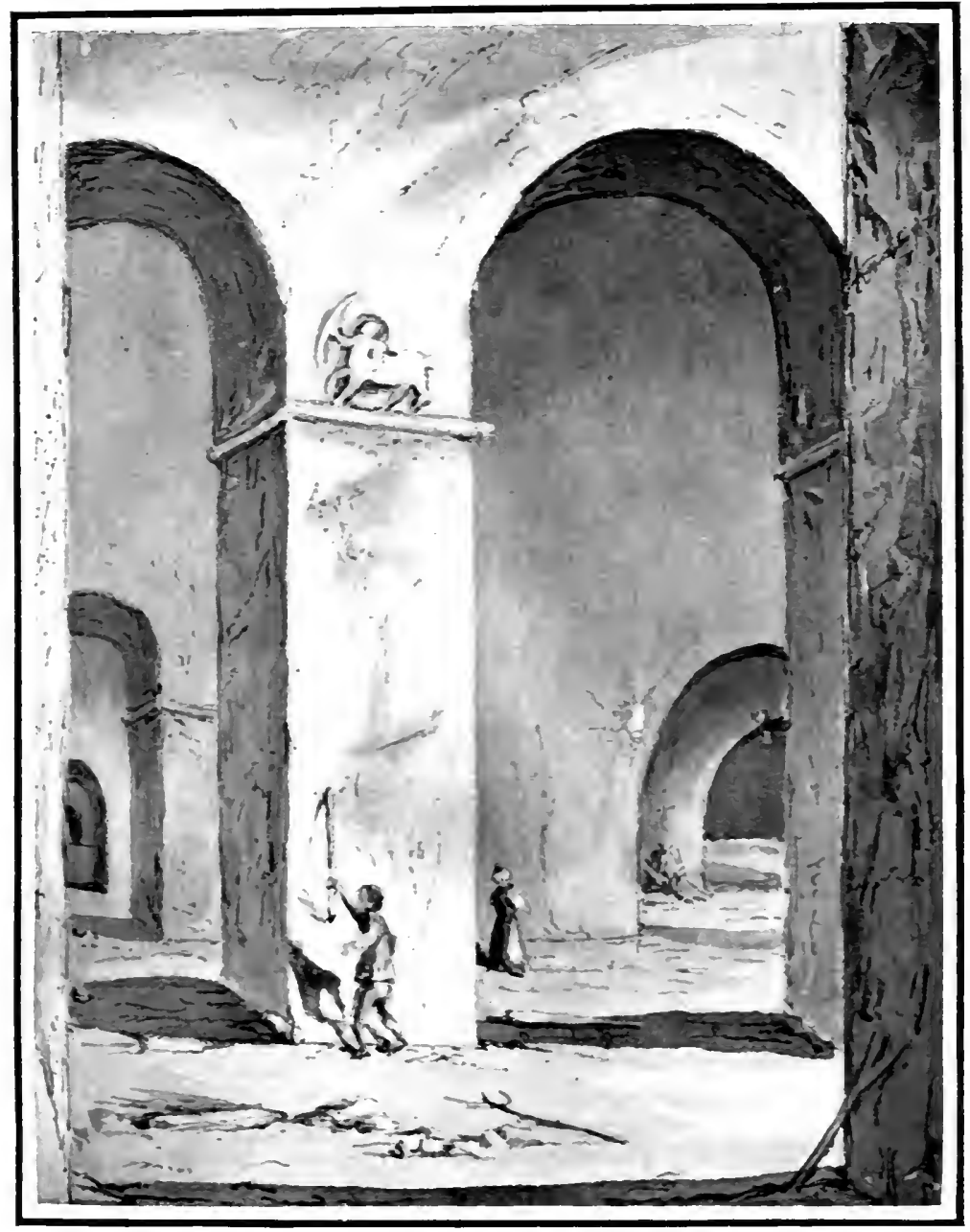

I.rterior of tile Moxolithic Church of S. Eyiliox, Dordogse Height from the foor, sixty feet. It is no longer used for divine worship. 


\section{SUBTERRANEAN CHURCHES}

Few scenes of quiet landscape can surpass that of the valley of the Dordogne from the road between Sauveterre and Libourne. It broke on me upon a breezy spring morning. The Dordogne, broad and blue, swept through the wide valley between banks dense with poplar and osier. The whole country wore a smiling aspect; the houses, built of freestone, looked fresh and comfortable, and were surrounded by their gardens. The maize-fields were as a rippling green sea. The flax-fields in bloom were sheets of the tenderest blue, and those of the Trifolium incarnatum red as blood, and the road was like a white ribbon binding together a variegated wreath. 'To the north of the Dordogne rose a grey cluster of buildings, the old town of S. Emilion, famous for its wine. It occupies the edge of a plateau. The only business pursued therein is the making of wine and of macaroons.

The entrance to S. Emilion is not striking. None of its buildings, except the keep of its castle are visible. The road dives into a grove of acacias, and then enters the town by a narrow street. 'The acacias were a mass of pink and white blossom, exhaling a sweet fiagrance.

In the middle of the eighth century lived a hermit named Emilian, born of obscure parents at Vannes in Brittany. He became known to the Count of that place, who took him into his service, where he showed himself profusely charitable to the poor with his master's substance. 'This led to his ignominious dismissal, and he wandered into the Saintonge, entered the Benedictine Order, and became baker to the monastery. But he proved so objectionable there that he was turned out. So he wandered further south, and finding a rock in the forest above the Dordogne, wherein was a small cave, out of which flowed a spring, he took up his abode therein. His fame soon brought disciples to him, and gathered admirers about him; and after his death in $\tau 6 \%$, a monastery of Bene181 


\section{SUBTERRANEAN CHURCHES}

dictine monks was settled there, and a town sprang up about it.

The cave of $\mathrm{S}$. Emilion still remains. In face of it rises a mass of rock with abrupt scarp towards the west and the market-place. Thence a street slopes up to the platform on the top of the rock. The front of the rock has an ambulatory before it pierced with windows and doors, and through these latter access is obtained to the interior of the rock, which is hollowed out into a stately church, dedicated to the three kings, Caspar, Melchior, and Balthazar.

This monolithic church has for its base a parallelogram measuring 120 feet by 60 feet. It is composed of two portions of unequal height. The anterior portion is a vestibule, narthex, or ambulatory to the church, and is only 21 feet high. The windows in this are of the flamboyant order, and the principal doorway is richly sculptured. 'The body of the church into which this vestibule opens is 95 feet long and 60 feet high. The body consists of a nave and side aisles, all excavated out of the living rock. Six windows light the interior, the three in the flamboyant style already mentioned, and above, set back the whole length of the narthex under circular-headed arches, are three plain, round-headed windows, like a clerestory, opening into the nave and aisles, one window in each.

Looking from the market-place at the church the spectators would suppose that the nave ran parallel with the vestibule, but this is not the case, it is at right angles to it.

The small upper windows cast but a chill and feeble light into the vast cavern, so that the choir and chapels are buried in perpetual twilight. The windows in the vestibule do very littletowards the illumination of theinterior. At the extremity of the nave, which is raised on steps to form a choir, anciently stood the high altar, but this has been removed. Above, where 182 


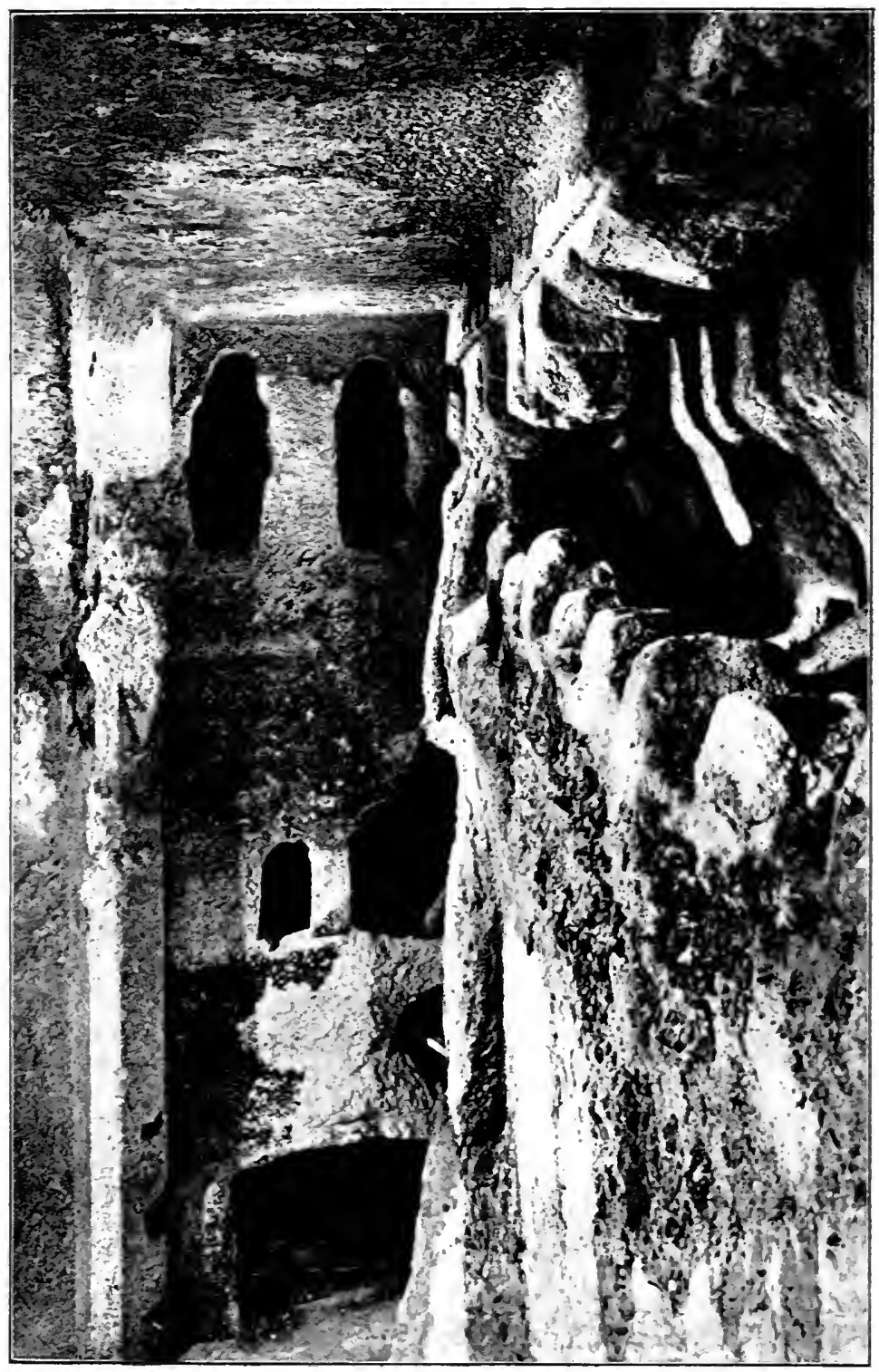

Interior of the Monolithic Cherch, AUbeterre, Charente. Showing the gallery of communication to the Seisneural pew, seen in face. The supports of the gallery vault have crumbled away within furty years, through neglect. 



\section{SUBTERRANEAN CHURCHES}

it was can be discerned faintly through the obscurity, a basrelief rudely sculptured, but very curious. It occupies the entire width of the choir ; on the right is an angel playing upon a stringed instrument, with outspread wings, as if in the attitude of soaring, and on the left, perched on a rock, is a monstrous animal with gaping jaws, bristling mane, and raised paws. In the midst of the group is a little old man armed with a stick, apparently repelling this monster. It has been conjectured that this is intended as a representation of the saint himself ready to deliver his votaries from the jaws of Hell. But it is more probable that the whole subject is allegorical of Death, armed with his scythe between the powers of Light and of Darkness. The choir arch is one of the boldest and most original conceptions in this marvellous temple. It consists of two gigantic angels carved out of the sandstone, with their feet upon the piers on each side, and their heads nearly meeting at the crown of the vault. Each has four wings, the two smaller wings are raised about their heads, forming a nimbus to each. The other two wings are depressed. These mighty angels were formerly whitened and partially gilt, and the effect of the great figures looming out of the dark vault is most impressive.

On the right side of the nave, at the spring of the arches, between two of the piers, is a centaur armed with a bow, cut in the stone, and on the opposite spandril are two goats, disposed back to back, also cut in the rock. On one of the piers is an inscription graven regarding the dedication of the church, but unfortunately the date is illegible. The exterior of the church is adorned with a noble portal, richly sculptured, of much later date than the church within.

On entering the church through this rich portal a feeling of astonishment comes over one. The exterior in no way corresponds with the interior, which is void of ornament. The piers are massive parallelograms without mouldings, 183 


\section{SUBTERRANEAN CHURCHES}

the arches between them semicircular, stilted, perfectly plain; a string alone marks the rise of the arch from the pier.

In the floor of one of the aisles is a hole through which a descent was anciently made into the crypt below the church; this crypt also is hewn in the solid rock, and has a funnel-shaped dome, a spiral flight of steps was cut in the rock round it descending from the church into the crypt. The descent must have been hazardous in the extreme unless the stairs were provided with a balustrade, of which at present no trace remains.

Admittance into the crypt is also obtained through a door cut in the face of the rock, but this was made in $\mathbf{1 7 9 3}$ when the soil and the bones of the old canons of the Church of the Three Kings were required for saltpetre to make gunpowder for the armies of the Republic. Over the door is a mask carved in the stone and a little window; above the monolithic church, standing on the platform of rock, is the exquisite flamboyant spire, not communicating with the church beneath, also a modern salle de danse.

Another subterranean church as interesting but not as well preserved is that of Aubeterre in Charente, on the Dronne. By the valley of the Dronne all movement of troops from the Limousin and Perigord into the Saintonge took place, and the rock of Aubeterre was considered of so great military importance that a strong castle was constructed on the summit, and its possession was contested repeatedly during the Hundred Years' War and the wars of religion. Its position was peculiar in this also, that it was in the seneschauté of the Angoumois, in the diocese of Périgueux, and for the purpose of taxation in the Limousin.

The town is built in the form of an amphitheatre on a chalk!hill that commands the Dronne. The hill is precipitous in parts, and is everywhere so steep that the roofs of the houses are below the gardens of those above them, 184 


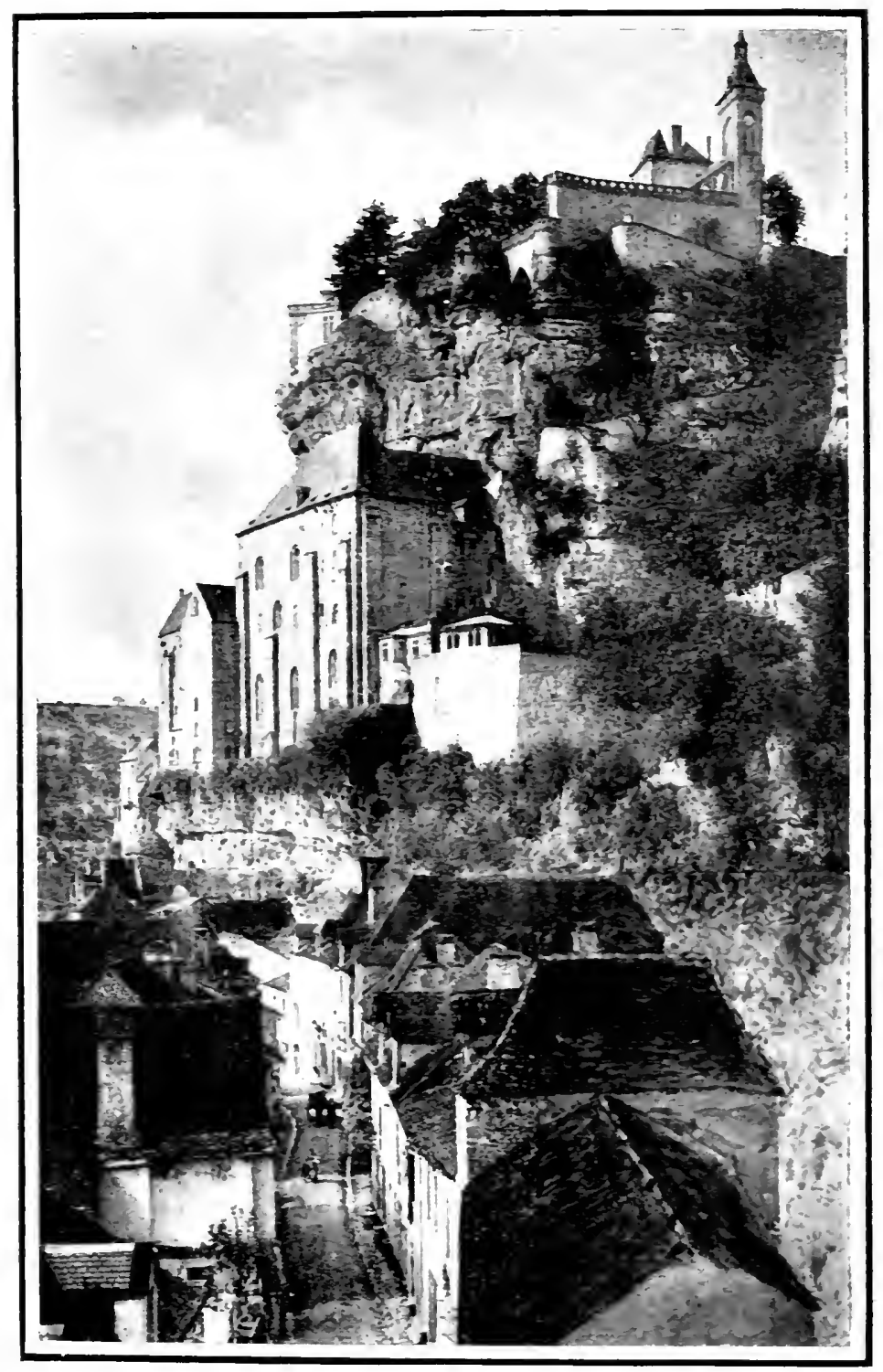

ROCAMADOTR

A cluster of chapels, some excavased in the rock. Zac haeus is erroneously supposed to have iived and died in one of them. A farrous place of pilgrimage. 


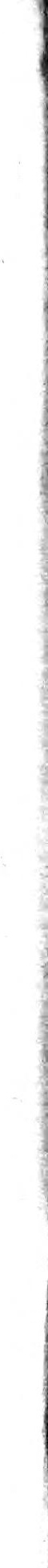




\section{SUBTERRANEAN CHURCHES}

and the saying there is, "Mind that your cattle be not found in your neighbour's stable by tumbling through the roof." The castle occupied a height cut off from the town by a deep cleft, that has its sides pierced with caverns, and its store chambers and cellars are dug out of the rock. But the most curious feature of Aubeterre is the monolithic church of S. John beneath the castle. The doorway admitting into it is on the lerel of the street, and gives access to a charnel-house with what would be termed arcosolia in the catacombs, on each side, and the floor is humpy with graves. This is 70 feet long by 16 feet wide. On the right hand it gives admission through a doorway cut in the rock to the church itself, consisting of a nave and side aisle divided from it by massive monolithic piers, very much decayed at the top. It is lighted by three round-headed windows like a clerestory without glass. At the further end is an arch admitting to an apse, in the midst of which is an octagonal monolithic tomb of Renaissance style, with columns at the angles, and surmounted by the statue of Francois d'Esparbes de Lussac, Marshal of Aubeterre, and the much mutilated figure of his wife in Carrara marble.

A gallery excavated in the rock above the arch into the apse is continued the whole length of the aisle, and turns to admit into the seigneural gallery or pew high up over the entrance whence he and his family could hear Divine Service.

On the right-hand side of the nave opens a second charnel-house, called by the people "the Old Church," also with its arcosolia; there is also a door by which exit is obtained into a small cemetery overgrown with briars and thorns, and with the head-crosses reeling in all directions, and utterly neglected. For centuries not this yard only, nor the two charnel-houses but also the floor of the church, have served as the burial-place of the citizens of Aubeterre, 185 


\section{SUBTERRANEAN CHURCHES}

and the floor is raised four feet above that of the apse though frequent interments. The last head cross I noted within the church bore the date 1860 .

The height of the church is said to be fifty feet. The castle above was sold about sixty years ago to a small tradesman of the town, who straightway pulled it down and disposed of the stones for building purposes, and out of the lead of the gutters, conduits, and windows made sufficient to pay the purchase-money.

Then he converted the site into a cabbage garden and vineyard. Not content with this he brought a stream of water in to nourish his cabbages. This leaks through and is rapidly disintegrating and ruining the church beneath, that was protected so long as the castle stood above it. Seven years ago the arched gallery in the aisle was perfect, now it has crumbled away. The piers were also intact, now they are corroded at the top. A stream pours down through the vault continuously by the monument of the Marshal. The church is classed as a monument historique, nevertheless nothing was done to prevent the damage effected by the destruction of the covering castle, and nothing is done now to preserve it from utter disintegration.

In my opinion the apse was excavated to receive the monument, which consists of a mass of chalk in position, with a hole on one side to receive the coffins let down into the seigneural vault; and this could not have been there with a high altar behind it. In a lateral chapel is a hole in the vault, through which the ropes passed to pull the bells that were hung in a tower above, but which has been destroyed.

In 1450 Aubeterre was in the possession of the English, and they sold it to the Count of Perigord. When the Huguenot troubles began, the Lord of Aubeterre threw himself into the movement and appropriated the lands and 


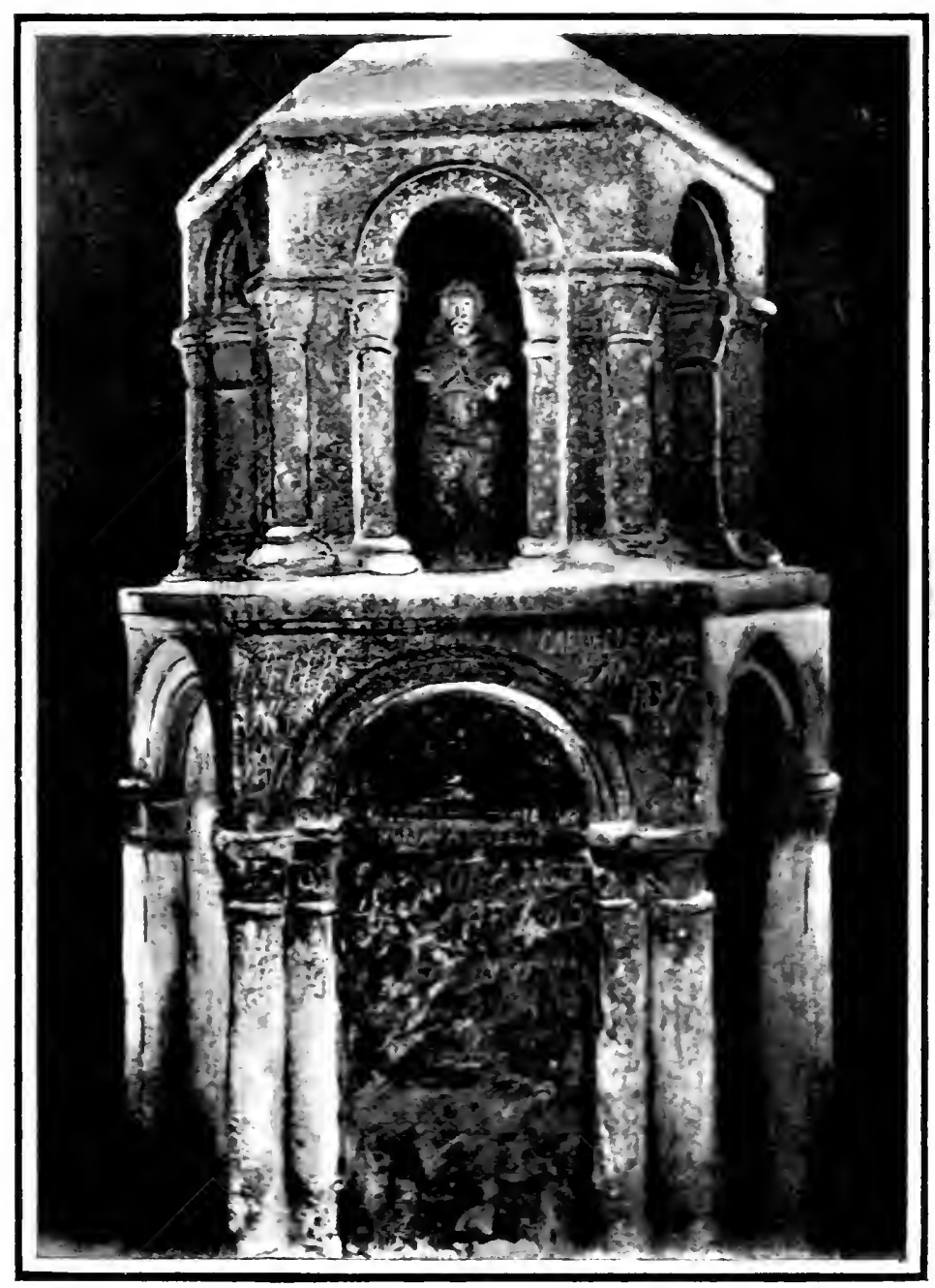

Atbeterre, Chareste

Mausoleum of François Espartes in the choir of the Subterranean Church. 



\section{SUBTERRANEAN CHURCHES}

revenues of the ecclesiastical foundations in the town. François d'Aubeterre was involved in the conspiracy of Amboise, and was sentenced to death, but pardoned. $\mathrm{He}$ deemed it expedient, however, to go to Geneva, where, as Brantôme informs us, he turned button-maker. In 1561 he was back again in Aubeterre, and converted the nonolithic church into a preaching "temple," sweeping away all Catholic symbols, and it remains bare of them to this day. His brother, Guy Bonchard, Bishop of Périgueux, was also an ardent Calvinist, and used his position for introducing preachers of the sect into the churches. Although disbelieving in Episcopacy, he did not see his way to surrendering the emoluments of his see. He was deposed in 1561, and Peter Fournier elected, whom the Huguenots murdered in his bed 14th July 1575 .

In 1568 Jeanne d'Albret issued orders to the gangs of men she sent through the country to lay hold of the royal revenues, to sequestrate and appropriate all ecclesiastical property, to raise taxes to pay themselres, and to require all municipalities to furnish from four to five soldiers apiece to replenish their corps.

Jeanne's power extended orer Lower Navarre, Béarn, the land of Albret, Foix, Armagnac, and other great seigneuries. Through her husband, Antoine de Bourbon, she could rule and torture Perigord, the Bourbonais, and the Vendomois. She had good cause to be offended with the Pope, for in 1563, with incredible folly, he threatened her with deposition from her throne, a threat he could not possibly execute. By enrolling and sending forth over the south to ravage and confiscate, she was a second Pandora letting loose the hurricane, slaughter, fire, famine, and pestilence, leaving Hope locked up behind.

Aubeterre played a conspicuous part in the wars of religion, and the Catholics in vain essayed to take it. The seigneur could always draw from the bands of Calvinist 187 


\section{SUBTERRANEAN CHURCHES}

soldiery to hold it, and it remained in their power till the peace of La Rochelle.

I might include Rocamadour in the Department of Lot among the interesting rock churches. It consists of a cluster of chapels clinging to the rock or dug out of it, and looking like a range of swallows' nests plastered against the face of the cliff. The people of the place fondly hold that Zaccheus, who climbed up a sycamore tree to see Our Lord pass by, came into Quercy, and having a natural propensity for climbing, scrambled up the face of the precipice to a hole he perceived in it, and there spent the remainder of his days, and changed his name to Amator. No trace of such an identification occurs before 1427, when Pope Martin V. affirmed it in a bull, although in the local breviary there was no such identification. It is extremely doulbtful whether any saint of the name of Amator settled here, the story concerning him is an appropriation from Lucca. ${ }^{1}$

But I will not describe this, one of the most remarkable sites in Europe, as I have done so already in my "Deserts of Southern France," and as of late years it has been visited by a good many English tourists, and the French railway stations exhibit highly coloured views of it, turning Rocamadour into a national show place.

At Lirac, in Gard, is La Sainte Baume, a small church or chapel, excavated out of the rock, 60 feet long, 45 feet wide, and 30 feet high. It is lighted by an aperture in the vault. Three other caves behind the choir are almost as large.

At Mimet, in Bouches-du-Rhone, is the church of Our Lady of the Angels, hewn out of limestone rock, with stalactites depending from the roof.

At Peyre, near Millau, in Tarn, is the church of S. Christophe, scooped out of the living rock, with above it an old crenellated bell tower.

1 Analecta Bollandiana, T. xxviii, pp. 57 et seq.

188 


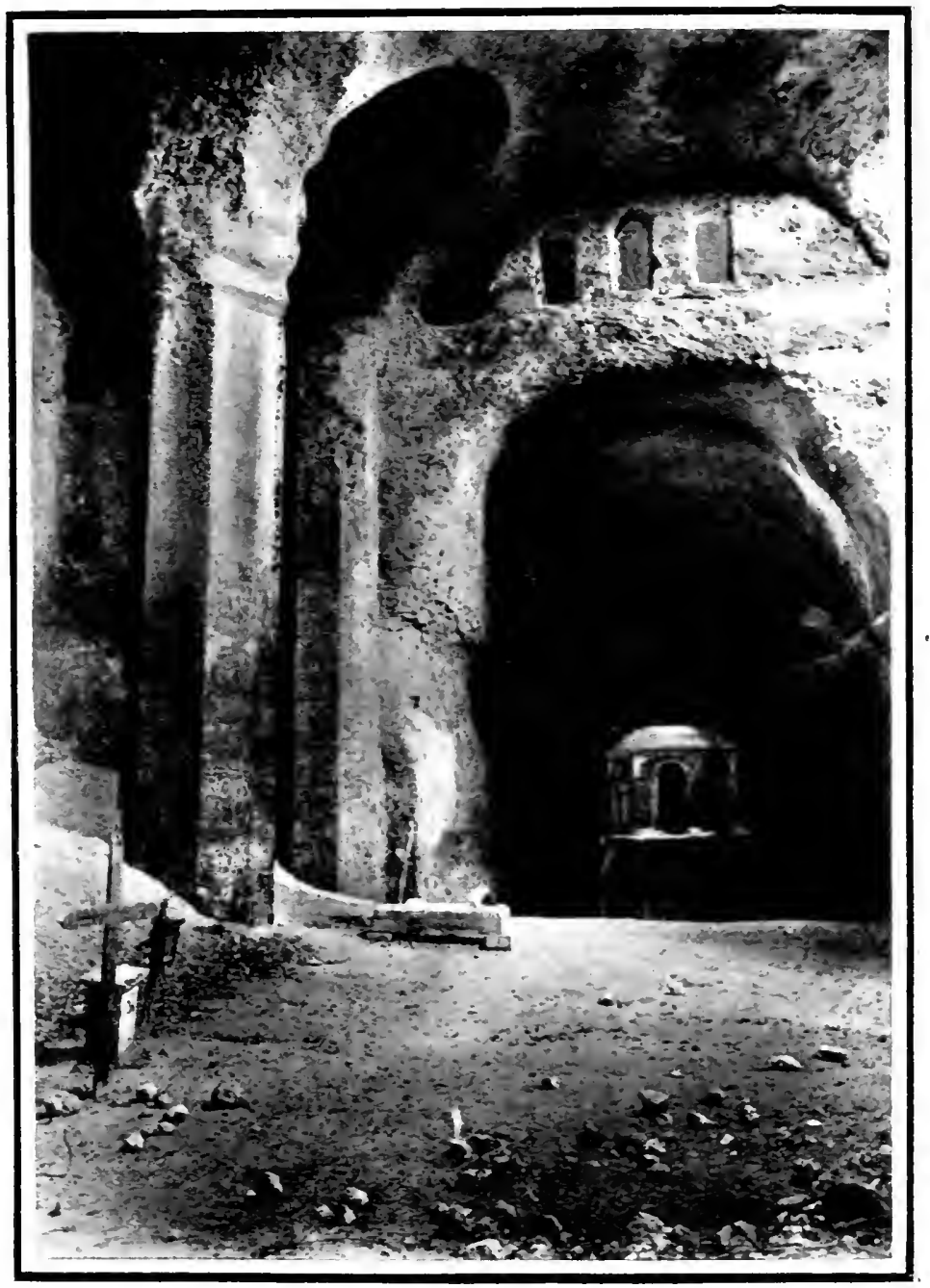

Subterraneax Church, AUbeterre

Looking east. In the choir is the mausoleum. The floor of the church is raised four feet by it having been made the parish cemetery. The process of degradation of the pillars is noticeable at their heads. 


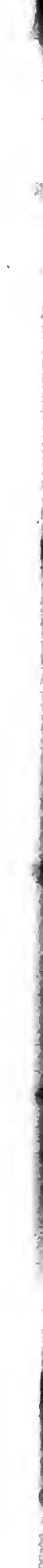




\section{SUB'TERRANEAN CHURCHES}

At Caudon, on the Dordogne, now in the parish of Domme, the old parish church is monolithic, entirely excavated in the rock, but with a structural bell-cot above it. As already mentioned, Caudon was a parish, but as owing to the devastations of the Companies, all the inhabitants had deserted it and fled to Spain, it was annexed to Domme. What is curious is that before it had been carred out of the limestone as a church there had been cave-dwellers in or about it, that have left their traces in the sides of the church. The Marquis de Maleville, who has his château near, has put the church in thorough repair, and it is still occasionally used.

Natural caves have been employed as churches or places of worship. 'Thus the Grotte des Fées, near Nimes, was used by the Calvinists for their religious assemblies before $\mathbf{1 5 6 7}$, when they obtained the mastery of the town, sacked the bishop's palace, and filled up the well with the Catholics, whom they precipitated into it, some dead and others half alive.

The Grotte de Jouclas, near Rocamadour, served the villagers of La Cave till the parish church was rebuilt. At Gurat, in Charente, the church of S. George is hollowed out of the rock ; it dates from the tenth century, it is believed, and preceded the present parish church, which was erected in the eleventh century, and is Romanesque. In the valley of the Borrèze, near Souillac (Lot), is a cave in which bones of the ursus speloeus have been found. It is used as a chapel to Notre Dame de Ste. Esperance.

At Lanmeur, in Brittany, is the very early crypt of S. Melor, a Breton prince put to death about the year 544 . The legend concerning him is rich in mythical particulars. His uncle, so as to incapacitate him from attaining the crown of Léon, cut off his right hand and left foot. The boy was then provided with a silver hand and a brazen foot. One day he was seen to use his silver hand in plucking filberts 


\section{SUB'TERRANEAN CHURCHES}

off a tree, whereupon his uncle had him murdered. 'The crypt is the most ancient monument of Christian architecture in Brittany. It measures 25 feet by 15 feet 6 inches, and is divided into a nave and side aisles by two ranges of columns hardly 4 feet high, sustaining depressed arches not rising above 3 feet 6 inches, and decorated with rudely sculptured trailing branches.

A still more curious subterranean chapel is near Plouaret,

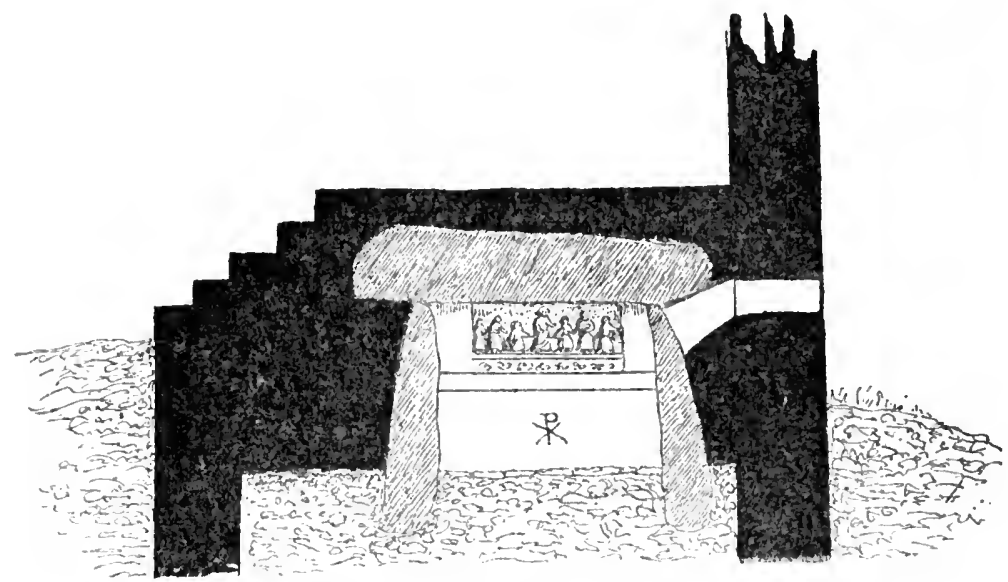

Section of the Dolmen Chapel of the Seven Sleepers near Plouaret.

in Côtes-du-Nord. It is, ingact,lalprehistoric dolmen under a tumulus, on top of which a chapel was erected in 1702-4. 'The descent into the crypt is by a flight of steps. 'The primitive monument consisted of two huge capstones of granite supported by four or five vertically planted uprights, but one, if not two of the latter have been removed. At the east end is an altar to the Seven Sleepers, and the comical dolls representing them stand in a niche above the altar.

In the north-west of Spain, at Cangas-de-Ones, near Oviedo, is a little church of probably the tenth or eleventh century, built on top of a cairn that covers a dolmen. This 


\section{SUBTERRANEAN CHURCHES}

latter consists of a circular chamber into which leads a gallery composed of fifteen upright slabs, corered by four others. The dolmen served as a crypt to the church, and from it have been recovered objects in stone and copper of a prehistoric period. A writer in the seventeenth century

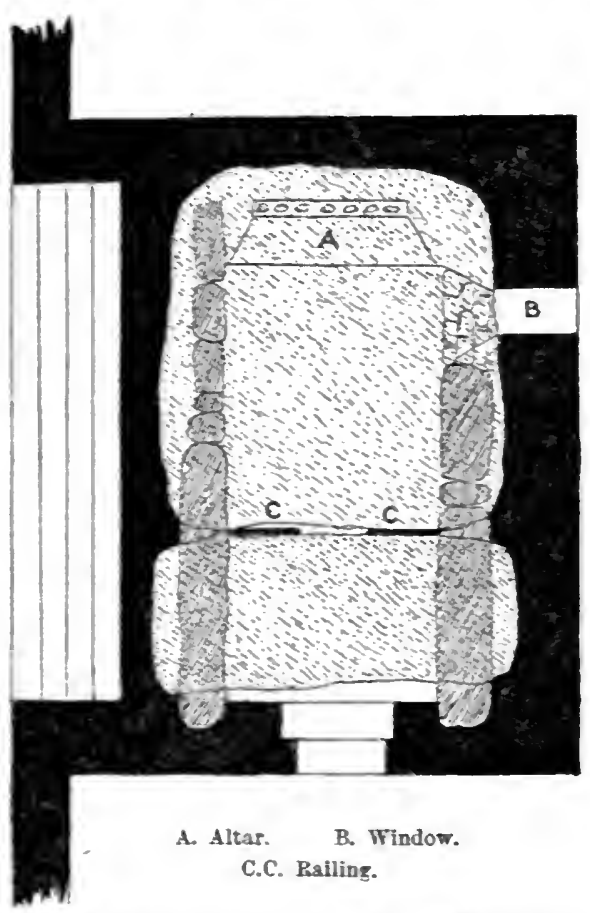

Plan of the Dolmen Chapel near Plouaret.

says that in his time devotees regarded the dolmen as the tomb of a saint, and scrabbled up the soil, and carried it away as a remedy against sundry maladies. ${ }^{1}$

The Bretons have a ballad, Gwerz, concerning the former monument. It is a miraculous structure dating from the Creation of the World: "Who will doubt that it was

1 Rerue mensulle de l'école d'A nthropologie, Paris, 1897.9 


\section{SUB'TERRANEAN CHURCHES}

built by the hand of the Almighty? You ask me when and how it was constructed. I reply that I believe that when the heavens and the earth, the sea, and all were created, then was this also made."

Although the dolmen is no longer underground, I must refer to that of Confolens near S. Germain-sur-Vienne, because it was originally under a tumulus. It is a dolmen, of which only the cover, a huge mass of granite remains intact, in an island of the Vienne. Underneath the slab are sculptured a stone axe with handle, and one without, also a cross. 'The capstone rests on four pillars of the twelfth century. Mr. Ferguson erroneously claimed the dolmen as evidence that rude stone monuments continued to be erected till late in the Middle Ages. But, in fact, the pillars are not of equal length, their capitals are not in line, nor are their bases. What is obvious is that the rude stone supports were removed one by one, and the Gothic pillars inserted in their place were cut exactly to the length required. Thus altered, the dolmen served as a baldachin or canopy over the stone Christian altar that is still in place beneath it. About this monument a chapel had been erected with apse to the east, measuring 36 feet by 15 feet. This has been destroyed, but the foundations remained till recently. 'The cross on the capstone was cut when the prehistoric monument was converted to use by Christians. To descend to the floor of the chapel a flight of steps had been constructed. The chapel was dedicated to S. Mary Magdalen.

In Egypt, in the Levant, cave-churches are common. The chapel of Agios Niketos, in Crete, is now merely a smoke begrimed grotto beneath a huge mass of rock on the mountain side. The roof is elaborately oruamented with paintings representing incidents in the Gospel story, and the legend of $\mathbf{S}$. Nicolas. Though it is no longer employed as a church, an event that is said to have happened some centuries ago invests it with special regard by the 


\section{SUBTERRANEAN CHURCHES}

natives. The church was crowded with worshippers on the eve of the feast of the patron, when the fires which the villagers who had assembled there had lighted near the entrance, where they were bivouacking for the night, attracted the attention of a Barbary corsair, then cruising off the island, and guided him to the spot unobserved. Suddenly and unexpectedly he and his crew, having stolen up the hill, burst upon the crowd of frightened Cretans. The Corsairs thereupon built up the entrance, and waited for day, the better to secure their captives for embarkation. But happily there was another exit from the cavern behind the altar, and by this the whole congregation escaped into another cave, and thence by a passage to a further opening, through which they stole out unobserved by the pirates.

The rock-hewn church of Dayn Aboo Hannes, "the convent of Father John," in Egypt, near Antinoe, has its walls painted with subjects from the New 'lestament; the church is thought to date back to the time of Constantine.

The passion for associating grottoes with sacred themes is shown in the location of the site of the Nativity at Bethlehem. 'There is nothing in the Gospel to lead us to suppose that the event took place in a cave, though it is not improbable that it did so. The scene of the Annunciation was also a rock-bewn cave, now occupied by a half-underground church, out of which flows the Virgin's Fountain.

In Gethsemane, "the chapel of the Tomb of the Virgin, over the traditional spot where the Mother of our Lord was buried by the Apostles, is mostly underground. Three flights of steps lead down to the space in front of it, so that nothing is seen above ground but the porch. But even after you have gone down the three flights of steps you are only at the entrance to the church, amidst marble pillars, flying buttresses, and pointed arches. Forty-seven additional marble steps, descending in a broad flight nineteen feet wide, lead down a further depth of thirty-five feet, and here you are surrounded by monkish sites and sacred 


\section{CHAPTER VIII}

\section{ROCK HERMITAGES}

\section{$\mathrm{T}$}

HERE is an account in the Times' Correspondent's record of Colonel Younghusband's expedition to Lhasa that when read haunts the imagination. It is the description made by $\mathrm{Mr}$. Landon of a Buddhist monastery, Nyen-de-kyl-Buk, where the inmates enter as little children and grow up with the prospect of being literally inmured in a cave from which the light of day is excluded as well as the society of their fellow-men, there to spend the rest of their life till they rot. Horace may say:

Jubeas miserum esse, libenter

Quatenus id facit;

but few Christians can feel this towards another human being, though of another race, religion, and under another clime.

"These men," said the abbot to Mr. Landon, "live here in the mountain of their own free will; a few of them are allowed a little light whereby reading is possible, but these are the weaker brethren; the others live in darkness in a square cell partly hewn out of the sharp slope of the rock, partly built up, with the window just within reach of the upraised hand. There are three periods of immurement. The first is endured for six months, the second, upon which a monk may enter at any time he pleases, or not at all, is for three years and ninety-three days; the third and last period is for life. Only this morning," said the abbot, "a hermit died after having lived in darkness for twenty-five 


\section{ROCK HERMITAGES}

years." Mr. Iandon goes on to say: "Voluntary this self-immolation is said to be, and perhaps technically speaking it is possible for the pluckier souls to refuse to go on with this hideous and useless form of self-sacrifice, but the grip of the Lamas is omnipotent, and practically none refuse."

$\mathrm{He}$ describes a visit to the cell of one of those thus immured: "'The abbot led us into a small courtyard which had blank walls all round it, over which a peach-tree reared its transparent pink and white against the sky. Almost on a level with the ground there was an opening closed with a flat stone from behind. In front of this window was a ledge eighteen inches in width with two basins beside it, and one at each end. The abbot was attended by an acolyte, who, by his master's orders, tapped three times sharply on the stone slab. We stood in the little courtyard in the sun and watched that wicket with cold apprehension. I think, on the whole, it was the most uncanny thing I saw in all 'I'ibet. What on earth was going to appear when that stone slab, which even then was beginning weakly to quiver, was pushed aside, the wildest conjecture could not suggest. After halfa-minute's pause the stone moved, or tried to move, but it came to rest again. Then, very slowly and uncertainly it was pushed back, and a black chasm was revealed. There was a pause of thirty seconds, during which imagination ran riot, but I do not think that any other thing could have been so intensely pathetic as that which we actually saw. A hand, muffied in a tightly wound piece of dirty cloth, for all the world like the stump of an arm, was painfully thrust up, and very weakly it felt along the slab. After a fruitless fumbling the hand slowly quivered back again into the darkness. A few moments later there was again one ineffectual effort, and then the stone slab mored noiselessly again across the opening. Once a day water and an unleavened cake of flour is placed for the prisoner upon that 197 


\section{ROCK HERMITAGES}

slab, the signal is given, and he may take it in. His diversion is over for the day, and in the darkness of his cell, where night and day, noon, sunset, and the dawn are all alike, the poor soul has thought that another day of his long penance was over."

Here is another account from the pen of Sven Hedin.

He visited the monastery of Sumde-pu-pe, where was a hernitage consisting of a single room five paces each way, built over a spring that bubbles up in the centre. Inside the hermit, had been walled up with only a tiny tunnel communicating with the outside world. Once inside, he was never again to see the light of day nor hear a human voice. The man Sven Hedin saw had been immured for sixty-nine year's, and wished to see the sun again.

"He was all bent up as small as a child, and his body was nothing but a light-grey parchment-like skin and bones. His eyes had lost their colour, and were quite bright and blind. Of the monks who sixty-nine years before had conducted him to the cell not one survived. ... And he had scarcely been carried out into the sunlight when he too, gave up the ghost." 1

S. Theresa once said that she had a vision of Hell. The torture did not consist of flames, but in being planted opposite a blank wall, on which to gaze through all eternity. The hermit in a Buddhist cell must have undergone this torture till all intelligence, all consciousness, save desire for food, was dead within him.

'There have been horrible instances of voluntary immurement in Christian Europe, and above all in the Christian East; but not quite-though very nearly-as bad as this. Moreover, not one line, not a single word in the Scriptures inculcates such self-annihilation. Christ set the example of retirement from the world into the wilderness for forty days, to a mountain apart for one night, to teach men 1 "Trans-Himalaya : Discoveries and Adventures in Tibet," Lond. 1910. 


\section{ROCK HERMITAGES}

occasionally and for a limited period, to withdraw from the swirl of business and the clatter of tongues. And S. Paul retired from the society of men after his conversion to gather his thoughts together, and prepare for his great missionary work. But that was something altogether different from ascetic abnegation of life and flight from its responsibilities.

The peopling of the solitudes of Syria and Egypt by solitaries was due, not to flight from persecution, but to revulsion from the luxury of the great cities, and very largely as an escape from compulsory military service. It was not a new thing. Judaism had been impregnated with Buddhism, or at all events with Brahminism, and with ideas of asceticism. 'The Essenes and 'Therapeutæ lived, the first in the time of the Maccabees upon the shores of the Dead Sea, and the last two centuries later, in Egypt. Both inhabited cells in the desert, preserving celibacy, renouncing property, pleasure, and delicate food, and consecrating their time to the study of the Scriptures, and to prayer. And yet celibacy was in violation of the principles of Judaism, which required every man to marry, in the hopes of becoming a progenitor of the Messiah. Further, they rejected the bloody sacrifices of the law, and would have nothing to do with the temple at Jerusalem. We can see by Philo's "On the Contemplative Life" how completely Alexandrian Judaism had sucked in Buddhist doctrine, and how Therapeutic asceticism formed the bridge from Buddhism to Christian monachism. In the same places where Essenes and Therapeutæ had been, there later we find Christian solitaries. "We can have no doubt," says Ferdinand Delaunay, "that the Therapeutic Convents which perhaps gave the first signal for conversion to the new faith, served also as the cradle for Christian monachism. History shows us, hardly a century later, this flourishing in the same localities on the borders of the lake Mareotis, 199 


\section{ROCK HERMITAGES}

and on the heights of Nitréa. And we cannot doubt but that Christian solitaries continued at Alexandria the work of their Jewish predecessors, and endeavoured to make their oracles serve for the propagation of the Gospel."

The language in which Philo describes the Therapeutre might be applied to the Christian monks of Egypt. I must condense his rambling account. The Therapeutæ abandon their property, their children, their wives, parents, and friends and homes, to seek out fresh habitations outside the city walls, in solitary places and in deserts. They pray twice in the day, at morning and evening, and the interval is wholly devoted to meditation on the Scriptures and elucidating the allegories therein. 'They likewise compose psalms and hymns to God, "and during six days each, retiring into solitude, philosophises, never going outside the threshold of the outer court, and indeed never looking out. But on the seventh day they all assemble, and sit down in order, and the eldest, who has the most profound learning, speaks with steadfast voice explaining the meaning of the laws."

They wore but one garment, a shaggy hide for winter, and a thin mantle for summer. Their food was herbs and bread, and their drink water. Philo concludes his account thus: "This then is what I have to say of those who are called Therapeutæ who have devoted themselves to the contemplation of nature, and who have lived in it, and in the soul alone, being citizens of heaven and of the world, and very acceptable to the Father and Creator of the universe because of their virtue; it has procured them His love as their most appropriate reward, which far surpasses all the gifts of fortune, and conducts them to the very summit and perfection of happiness."

It was not among the Jews alone that the solitary life was cultivated. In the Serapium of Thebes were also

1 Delaunay (F.), Moincs et Sibylles, Paris, 1874, p. 316. 200 


\section{ROCK HERMITAGES}

heathen monks leading a very similar life. That Persian Manichæism had infected Jews and heathen as well there can exist little doubt. ${ }^{1}$

In 177, in Lyons, when S. Pothinus and others were arrested, thrown into prison, tortured and killed for the Faith, there was one of the martyrs who caused offence to the rest because "he had long been used to a very austere life, and to live entirely on bread and water. He seemed resolved to continue this practice during his confinement, but Attalus (another martyr), after his first combat in the theatre, understood by revelation that Alcibiades gave occasion of offence to others by seeming to favour the new sect of the Montanists (a Christian phase of Manichæism), who endeavoured to recommend themselves. by their extraordinary austerities. Alcibiades listened to the admonition, and from that time ate of everything with thanksgiving to God." 2

But, although Buddhism affected the lives of certain Christians, it in no way touched their faith-that life was the result of contact with Manichæism, which taught that all matter was evil, and that the flesh must be subdued, as essentially ungodly. The Buddhist religion in its ethics is the absolute reverse of the Christian. The Buddhist prays and tortures, and stupefies himself for purely selfish reasons, so as to excape reincarnation in the form of a bug, a louse, or a worm, by the destruction within himself of all human passions and inclinations. His self-torture is undertaken for the object of absorption into Nirvana, only to be reached by reducing the mind and heart to absolute indifference to every animal desire, and thus to escape the eternal revolution of metempsychosis. "No man liveth to himself, and no man dieth to himself," is a maxim incom-

1 Philo gives an account of the sacred banquets of the Therapeuta that strongly reminds us of the Agaræ of the Early Christians.

: Eusebius, Hist. Eccl., v. i. 


\section{ROCK HERMITAGES}

prehensible to a Buddhist. As Mr. Landon says: "The spiritual brigandage of the Lamas finds its counterpart in many other creeds, but it would be unjust not to record in the strongest terms the great radical difference that exists between Lamaism at its best and Christianity at its worst. 'There has never been absent from the lowest profession of our faith a full recognition of the half-divine character of self-sacrifice for another. Of this the Tibetians know nothing. 'The exact performance of their duties, the daily practice of conventional offices, and continual obedience to their Lamaic superiors is for them a means of escape from personal damnation in a form which is more terrible perhaps than any monk-conjured Inferno. For others they do not profess to have even a passing thought. Now this is a distinction which goes to the very root of the matter. The fact is rarely stated in so many words, but it is the truth that Christianity is daily judged by one standard, and by one standard only-its altruism, and this complete absence of carefulness for others, this insistent and fierce desire to save one's own soul, regardless of a brother's, is in itself something that makes foreign to one the best that Lamaism can offer."

One day a gnat stung S. Macarius, and he killed it. To punish himself for this, he went to the marshes of Scete, and stayed there six months. When he returned to his brethren he was so disfigured by the bites of the insects that they recognised him only by the tone of his voice. A Brahmin would have been filled with remorse lest he had killed a reincarnation of his grandmother, but the Egyptian ascetic only because he had given way to momentary irritation.

One has but to read the sayings of the Fathers of the Desert to see that no vein of Brahminism or Buddhism had tinctured their faith, however deeply it may have coloured their practice. When plague raged in Alexandria, they were ready to quit their cells and hasten into the cities to 202 


\section{ROCK HERMITAGES}

minister to the sick and dying; when the faith, as they understood it, was menaced, to champion the truth.

That the Egyptian hermits, flying from association with the world, should betake themselves to caves, is hardly to be wondered at. In that land the rocks are pitted with artificial grottoes, which were the tombs of the ancient Egyptians, and were commodious and to be had without asking leave of any one.

Twice was Athanasius obliged to fly from the fury of the Arians, and to take refuge among the solitaries in their caves. Once he was constrained to remain in concealment in his father's tomb, also a cavern. When he was banished to Trèves, tradition says that he would not occupy a house, but sought out a grotto in a hill beyond the Moselle, and made his abode therein.

'The filiation between the Syrian and Egyptian solitaries with the hermits of Buddhism may be made out with some plausibility. In the East sanctity and asceticism are inseperable. The smug missionary who cannot preach the Gospel apart from a wife, mosquito curtains and a cottage piano, and who travels from one station to another in a palanquin borne by sweating natives, does not impress the imagination of an Oriental, and has small chance of making converts. It was possibly much the same with the barbarians who overwhelmed the Roman Empire. To strike their imagination and win them to the Cross, it may belthat asceticism was a necessary phase of mission work. "The Spirit breatheth where $\mathrm{He}$ wills, and thou canst not tell whence $\mathrm{He}$ cometh or whither He goeth," is the Vulgate rendering of S. John iii. 8. But if it was at one time a necessary phase, it ceased to be so when the effect required was produced; and from the close of mediæval times the hermit was an anachronism. The life of S. Antony by Athanasius, and the Historia Lausiaca or "Lives of the Fathers of the Desert," by Palladius (died c. 430), were published in the West, and inflamed minds 203 


\section{ROCK HERMI'TAGES}

with the desire to emulate the ascetics of Syria and Egypt; and speedily there were zealots who sought out retreats in the dens of the earth, in which to serve God in simplicity.

Some anchorites ${ }^{1}$ are commemorated in both the Greek Menæa and the Roman Martyrology more worthy to be esteemed Buddhists than Christian saints. Theodoret, who wrote A.D. 440, describes the lives of two women of Berca, whom he had himself seen. They lived in a roofless hovel with the door walled up and plastered over with clay, and with a narrow slit left for a window, through which they received food. They spoke to those who visited them but once in the year, at Pentecost; not content with the squalor and solitude of their hut, they loaded themselves with masses of iron which bent them double. Theodoret was wont to peer in through the chink at the revolting sight of the ghastly women, a mass of filth, crushed double with great rings and chains of iron. Thus they spent forty-two years, and then a yearning came on them to go forth and visit Jerusalem. 'The little door was accordingly broken open, and they crawled out, visited the Holy City, and crawled back again.

Another visited by 'Theodoret was Baradatus, who built himself a cabin on the top of a rock, so small that he was unable to stand upright in it, and was obliged to move therein bent nearly double. The joints of the stones were, moreover, so open that it resembled a cage and exposed him to the sul and rain. 'Iheodosius, patriarch of Antioch, as a sensible man, ordered him to leave it. 'Then Baradatus encased himself in leather so that only his nose.and mouth were visible. Nowhere was the imitation earried to such wild extravagance as in Ireland. S. Findchua is described as living like an Indian fakir. In his cell he suspended himself for seven years on iron sickles under his arm-pits, and only

1 Properly an anchoritc is a recluse, walled into his cell; a monk is a solitary; and an eremite or hermit is a dweller in the desert. 


\section{ROCK HERMITAGES}

descended from them to go forth and howl curses on the enemies of the King of Leinster.

In England also there was extravagance. S. Wulfric, who died in 1154, encased himself in a coat of chain-mail worn next his skin even in winter, and occupied a cell at Hazelbury in Somerset. S. Edmund of Canterbury (died 1242) wore a shirt of twisted horsehair with knots in it, and bound a cart rope round his waist so that he could scarce bend his body. In Advent and Lent he wore a shirt of sheet-lead. Thomas à Becket, when slain, was found by the monks of Canterbury to be wearing a hair shirt and hair-cloth drawers, and their admiration became enthusiastic when they further discovered that this hair-cloth was "boiling over" with lice. That this species of sanctity is still highly approved and commended to the imitation of the faithful we may suppose from the fact that Pius IX. in 1850 beatified the Blessed Marianna, because she was wont to sleep in a coffin or on a cross, and on Fridays hung herself for two hours on a cross attached to it by her hair and by ropes. On broiling hot days she denied herself a drop of water to quench an almost intolerable thirst. Verily Manichæism has eaten like a canker into the heart of the Latin Church.

But the early anchorites of Europe were not usually guilty of such extravagance. They were earnest men who sought by self-conquest to place themselves in a position in which they could act as missionaries. It was their means of preparing for the work of an evangelist. In most cases the apostle of a district sunk in paganism had no choice, he must take up his abode in a cave or in a hovel made of branches. In the Gallo-Roman cities the Christian bishops had gradually taken into their hands the functions of the civil governors. They were men of family and opulence, and lived in palaces crowded with slaves. They did nothing whatever towards the conversion of the country folk, the pagani. This was the achievement of the hermits. Till the peasants 205 


\section{ROCK HERMITAGES}

had been Christianised they would not invite the preacher of strange doctrines under their roofs, they looked on him with dislike or mistrust as interfering with their cherished superstitions and ancestral custons. He could not force his society on reluctant hosts.

S. Beatus, a British or Irish missionary, settled into a cave above the lake of Thun, dreaded by the natives as the abode of a dragon. He succeeded in his work, and died there at the advanced age of ninety. In 1556 the Protestant Government of Berne built up the mouth of the grotto and set soldiers to repel the pilgrims who came there. Now a monster hotel occupies the site, and those who go there for winter sport or as summer tourists know nothing or care less about the abode of the Apostle whence streamed the light of the Gospel throughout the land.

Below the terrace that surrounds the height on which Angoulême is built is the cave of S. Cybard (Eparchius died 581). An iron gate prevents access to it, and the path down to it is strewn with broken bottles and sardine tins. No one now visits it. But within, where are an altar and the mutilated statue of the saint, lived the hermit who in the sixth century did more than any other man to bring the people of the Angoumois out of darkness into light. But, as already said, when the work of evangelisation was done, then the profession of the hermit was no longer required, and such anchorites as lingered on in Europe through the Middle Ages to our own day were but degenerate representatives of the ancient evangelical solitaries.

A few years ago hermits abounded in Languedoc. 'They took charge of remote chapels on mountain tops, or in caves and ravines. They were always habited as Franciscan friars, but they were by no means a reputable order of men, and the French prefêts in conjunction with the bishops have suppressed them.

They were always to be seen on a market day in the 206 


\section{ROCK HERMITAGES}

nearest town, not infrequently in the taverns, and in the evening festooning along the roads on their way back to their hermitages, trolling out convivial songs spiced with snatches of ecclesiastical chants. "Mon Dieu," says Ferdinand Fabre," "I know well enough that the Free Brothers of S. Francis, as they loved to entitle themselves, had allowed themselves a good deal of freedom, more than was decorous. But as these monastically-habited gentry in no way scandalised the population of the South, who never confounded the occupants of the hermitages with the curés of the parishes, why sweep away these fantastic figures who, without any religious character, recruited from the farms, never educated in seminaries, peasants at bottom, in no way priests, capable, when required, to give a helping hand with the pruning knife in the vineyard, or with the pole among the olives, or the sickle among the corn. Alas! they had their weaknesses, and these weaknesses worked their ruin." The salt had lost its savour, wherewith could it be seasoned?

It was not in Southern France alone that the part of the hermit was played out. An amusing incident in the confession of Fetzer, head of a gang of robbers who infested the Rhine at the end of the eighteenth century, will go some way to show this. The gang had resolved on "burgling" a hermit near Lobberich. Had he been an eremite of the old sort, the last place in which robbers would have expected to find plunder would be his cell. But in the eighteenth century it was otherwise, and this particular hermit kept a grocer's shop, and sold coffee, sugar, and nutmegs. The rogues approached the cell at night, and as a precaution one of them climbed and cut the rope of the bell wherewith the hermit announced to the neighbourhood that he was about to say his prayers. Then they broke open his door. In Fetzer's own words, "The hermit was

1 Barnabé, Paris, 1899.

207 


\section{ROCK HERMI'TAGES}

not at home, but as we learned, had gone a journey in connection with his grocery business. In the hermitage, however, we found several men placed there to keep guard over his goods. We soon settled them, beat them with our cudgels and cast them prostrate on the floor. Then we burst open all the chests and cupboards, but found little money. There was, however, plenty of tea and sugar. As we were about to leave, a fearful storm came on, and without more ado we returned into the hermitage to remain there till it was overpast. In order to dissipate the tedium, we ransacked the place for food, and found an excellent ham and wine in abundance. I assumed the place of host. Serve the meal! Bring more! I ordered, and we revelled and shouted and made as great a din as we liked. In the second room the hermit had a small organ. I seated myself at it; and to make the row more riotous I played as well as I was able. The laughter and the racket did not cease till morning broke. Then I dressed myself up in the hermit's cowl and habit, and so went off with my comrades." 1

I remember visiting a hermit in 1868 who lived on a ledge in the cliff above S. Maurice in the Vallais, where was a cave that had been occupied by the repentant Burgundian King Sigismund. He cultivated there a little garden, and I have still by me a dried bouquet of larkspur that he presented to my wife on our leaving after a pleasant chat. A pilgrimage to the cave was due on the morrow, and he had just returned from the town whither he had descended to borrow mugs out of which the devotees might drink of the holy spring that issued from the cave.

The Wild Kirchlein, in Appenzell, is now visited rather by tourists than by pilgrims. A huge limestone precipice rises above the Bodmenalp, that is a paradise of wild flowers. A hundred and seventy feet up the cliff gapes a cavern, and at its mouth is a tiny chapel. It is reached by what is now 


\section{ROCK HERMITAGES}

a safe pathway and over a bridge cast across a chasm. But formerly the ascent could not be made without danger. In the beginning of the seventeenth century, some Alpine shepherds, who had reached the cave, reported that they had seen in it the remains of an altar. This aroused interest, and in the summer of 1621 a Capuchin named Tanner ascended to the cave, blessed, and consecrated it as a place of pilgrimage. He said mass there and preached. He was shortly afterwards called away to Freiburg, and for thirty years the cave was disregarded and neglected. But at the end of that time Tanner returned to Appenzell, and interested the parish priest Ulmann in it. When war broke out between Schwyz and Zurich in 1656, Ulmann concealed the treasures of the church in the care. This drew attention to it, and shortly after an altar was furnished with what was needful, and on the Feast of S. Michael in 1657 mass was again said there. Various matters-loss of friends, and contests with the secular authorities-wearied Ulmann, and he resolved on retiring as a hermit to the cave in the cliff, taking with him, however, an attendant. The swallows left, the winter storms came on, yet he braved the wind and cold, and remained a tenant of the cave for two winters and as many summers; but then, by order of the Bishop, he left to act as chaplain to a convent in Lindas. There he spent nine years, till falling ill, he felt a craving for the purer air of his Appenzell home, and obtained leave to return and again re-tenant the beloved cave. In his last will he bequeathed the Upper Bodmen Alp that was his ancestral inheritance for the maintenance of the Holy Grotto. After his death the little chapel with its tower was built, and a Capuchin friar occupied the hermitage. In 1853, the last hermit there, Brother Antony Fassler, fell down the precipice whilst gathering herbs. Since then there has been no such picturesque object to lead the visitor through the recesses of the cavern and show the stalactites; that office 209 


\section{ROCK HERMITAGES}

is now performed by the innkeeper of the hotel on the Alp.

The cave of S. Verena is one of the favourite pilgrim resorts in Switzerland. It is near Soleure, and lies in a valley of a spur of the Jura. According to the received tradition she ran after the Theban legion-in modern parlance was a camp-follower, but deserted the soldiers here, and took up her abode in this grotto. There is no mention of this hermitage earlier than 1426, and the legend has grown up since. That the cave was much more ancient, and was invested with holy awe, is no doubt true. In fact, there is reason to believe that Verena was a German goddess. ${ }^{1}$ Her symbol is a comb, and in the wall are cut these words :

Pcctore dum Christo, dum pectine servit egenis,

Non latuit quondam sancta Verena cavo;

that is to say, serving Christ and combing the heads of the poor, the holy Verena lived unconcealed in this grotto.

The way to the chapel is through woods, the valley closing in till bold rocks are reached. In a niche is a statue of the Magdalen, with the inscription, "I sleep, but my heart waketh." A few steps further is a representation of the Garden of Gethsemane. From this a long and steep stair leads up to the chapel, cut deep in the rock, with an altar in it. Behind this is the Holy Sepulchre carved in the stone, in the seventeenth century by the hermit Arsenius. On the other side of the chapel a long stone stair leads again into the open air. Under this stair is a hole in the rock into which the hand can be thrust. According to a "pious belief" the Saint one day was much tormented with the remembrance of the military, and longed to resume her pursuit of them, and she gripped the rock, which yielded like wax to her fingers.

1 Rocholz, Dei Gaugöttinnen, Leipzig, 1870. 


\section{ROCK HERMITAGES}

Another Swiss rock hermitage is that of the Magdalen near Freiburg, in the cliff on the right bank of the Saane. At the close of the seventeenth century it was enlarged by a hermit, John Baptist Duprés, and his comrade John Licht. They worked at it for twenty years. Duprés dug a number of cells out of the sandstone, a kitchen with a chimney, a dining-room, a church, and a stable. The church measures 63 feet long, 30 feet wide, and is 22 feet high. He built a tower to his church, and gave his chimney the height of 90 feet so as to ensure that his fire should not smoke. The hermit Duprés was drowned in $\mathbf{1 7 0 8}$ as he was rowing over the river a party of scholars who had come to visit him. No hermit lives there now. His residence is occupied by a peasant with his family.

On the Nahe, that flows into the Rhine, is the little town of Oberstein, whose inhabitants are nearly all employed in cutting and polishing agates, sardonyxes, and various other stones prized by ladies. Precipitous cliffs arise above the town, and contract the space on which houses could be raised, and these rocks are crowned by two ruined castles, the Older and the Newer Oberstein. About half-way up the face of the cliff, 260 feet above the river, can be seen a tiny church, to which ascent is made by flights of steps. The old castle rises above this, and stands 360 feet above the river, but its remains are reduced to a fragment of a tower. Separated from it by a notch in the rocks is the new castle that was destroyed by fire about thirty-five years ago.

In the old castle lived in the eleventh century two brothers, Wyrich and Emich von Oberstein. Both fell in love with the daughter of the knight of Lichtenberg, but neither confessed his passion to the other. At last, one day Emich returned to the castle to announce to his brother that he had been accepted by the fair maid; Wyrich, in an impulse of jealousy, caught his brother by the throat and hurled him down the precipice. His conscience at once 211 


\section{ROCK HERMITAGES}

spoke out, and in the agony of his remorse he had resort to a hermit who bade him renounce the world, grave for himself a cell in the face of the melaphyre clay-the hermit did not give to the rock its mineralogical name-and await a token from heaven that he was forgiven. Accordingly Wyrich von Oberstein scrambled up the face of the cliff as high as he could possibly go, and there laboured day after day till he had excavated for himself a grotto in which to live and expiate his crime. And a spring oozed out of the rock in his cave, and was accepted by him as the promised token of pardon. After a while he obtained that a little church should be consecrated which he had constructed at the mouth of his cave. On the day that the bishop came to dedicate the structure he was found dead.

What is supposed to be his figure, that of a knight in armour, is in the chapel. This latter was rebuilt in 1482, and the monument came from the older structure. The chapel has been handed over to the Calvinists for their religious services, which is the humour of it, as Nym would have said.

Beside the highroad (route nationale) from Brive to Cahors, but a very little way out of the town, is a mass of red Permian sandstone perforated with caves. In 1226 S. Anthony of Padua was at Brive, and resided for a while in one of them. Since then it has been held sacred and occupied by Franciscans, who erected a convent above it; in so doing they cut into and mutilated some very ancient artificial workings in the sandstone for the contrivance of rock habitations. The eave, however, was neglected when the Franciscans were expelled at the Revolution, but they returned in 1875 and rebuilt or greatly enlarged their convent, only to be expelled again in 1906. 'The grottoes, now converted into chapels to the number of four, are in a line under the superstructures, that in the middle the actual hermitage. This, moreover, has been cut out of the 212 


\section{ROCK HERMITAGES}

rock artificially, at a higher level than the others, that are natural and are untenable, owing to the incessant drip of water from the roofs. The first cave is dedicated to $\mathbf{S}$. Francis of Assisi, but it is a rock shelter rather than a cave. It is natural, but in one corner a small water-basin has been scooped. The second cave is mainly natural, but partly artificial; it is dedicated to Notre Dame Auxiliatrice. The third, reached by steps, is wholly artificial, and before the stairs were built to lead to it, was inaccessible save by a short ladder. It placed the occupant in safety from invasion by wolves or other objectionable visitors. It measures 21 feet by 15 feet. This, which was the habitation of S. Anthony, communicated with the two lower cares, one on each side, by lateral openings.

The fourth cave is that of Des Fontaines, in which are basins of water cut in the rock, receiving the everlasting drip from above.

It is impossible to give one tithe of the hermitages in caves that are to be seen in Europe; but a few words may be devoted to La Sainte Beaume in Var, where, according to tradition, Mary Magdalen spent the end of her days. The tradition is entirely destitute of historical basis, and rests on a misconception. Scott has described the cave with tolerable accuracy in "Anne of Geierstein," though he had not seen it himself.

The cave is in the range of cretaceous limestone that runs east and west to the north-east of Marseilles, and at La Beaume Sainte reaches the height of 3450 feet. The wild flowers, the fine forest, and the white rocks impart great interest to the visit without consideration of historical and legendary association. The botanist will find the globe flower, the anemone, the citisus, the man, the bee, the fly orchids, and the Orchis militaris in considerable abundance; also banks of scented violets.

The grotto is at a considerable height above the valley. 213 


\section{ROCK HERMITAGES}

According to the legend, as already said, Mary Magdalen spent the close of her life here, and numerous anchorites settled in the caves around. In the fifth century Cassian placed monks in the grotto, but they were driven away by the barbarians, and La Sainte Beaume fell into complete oblivion till the thirteenth century.

The cave is lofty and spacious, not a little damp, and water drips from the roof. To protect the altar a baldachin has been erected over it. At the extreme end is a raised dais of natural rock, on which the saint is supposed to have made her bed. Another cave is that of the Holy Sepulchre, which was formerly occupied by the monks of S. Cassian. From the Sainte Beaume a path leads upwards to the Saint Pilon, the highest pinnacle of the rock which here rises to a point, out of which grow wild pinks and aromatic shrubs, and where falcons make their nest. According to the legend, Mary Magdalen was elevated by the hands of angels to this point seven times a day, there to say her prayers, which proceeding surely entitles her to a place as the patroness of aviation.

At Sougé, on the Loir, a little below the troglodyte town of Trôo already described, half-way up the cliff is the cavechapel of S. Amadou. It is 45 feet deep and 15 feet wide. The altar is at the end surmounted by a niche containing a statue of the saint, and to this formerly pilgrimages were made from all the valleys round. But this is a thing of the past, for it is now private property and converted into a cellar. What is peculiar about this chapel is that it is surrounded by a gallery also rock-hewn, and it was customary for the pilgrims to pass round the chapel through this gallery before entering it.

At Villiers, near Vendôme, is the chapel of S. Andrew, that was formerly inhabited by a hermit. It is divided into two chambers. That on the left is the chapel proper, with its altar. Above the other opening is a bas-relief of 214 


\section{ROCK HERMITAGES}

the Crucifixion. When levelling the floor of this hermitage a few years ago, so as to convert it into a commodions private dwelling, a number of skeletons were found in graves sunk in the rock.

Montserrat is famous throughout Spain on account of its statue of the Virgin, which is supposed to have been made by $\mathrm{S}$. Luke, and brought to Barcelona in the year 50 by

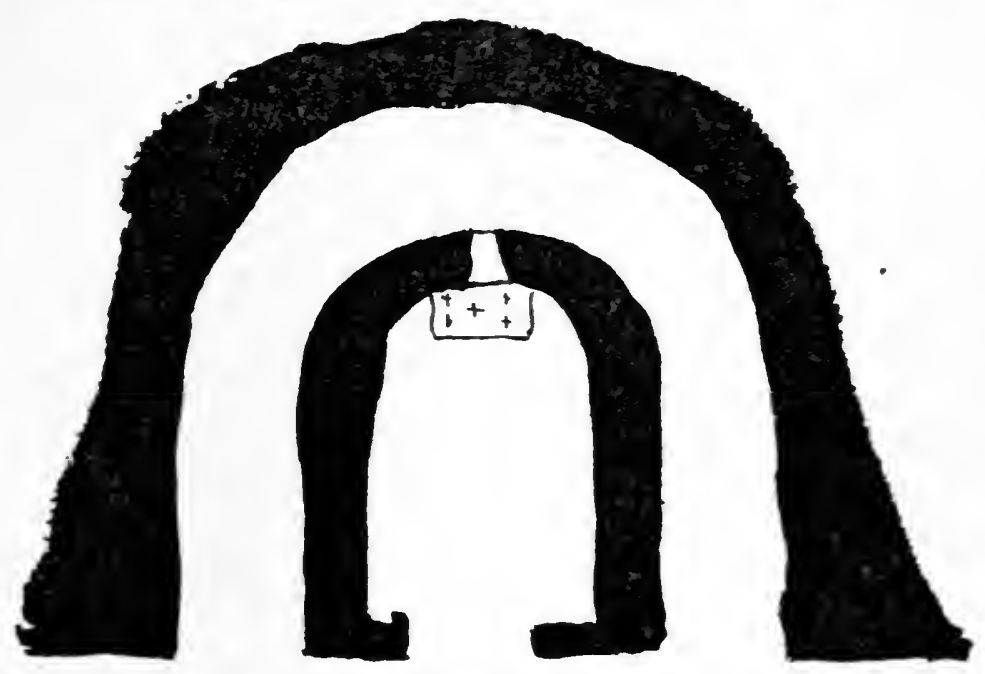

Plan of the Chapel of S. Amadon.

S. Peter, which, of course, is nonsense. S. Luke never painted, and S. Peter never visited Spain. This extraordinary mountain derives its name from its saw-like appearance, Mons serratus. It consists of pudding-stone, "a strange solitary exiled peak, drifted away in the beginning of things from its brethren of the Pyrenees, and stranded in a different geological period." Mr. Bayard Taylor thus describes the summit after a two hours' climb. "Emerging from the thickets we burst suddenly upon one of the wildest and most wonderful pictures I ever beheld. A tremendous wall of rock arose in front, crowned by colossal turrets, 215 


\section{ROCK HERMITAGES}

pyramids, clubs, pillars, and ten-pin shaped masses, which were drawn singly, or in groups of incredible distinction, against the deep blue of the sky. At the foot of the rock the buildings of the monastery and the narrow gardens completely filled and almost overhung a horizontal shelf of the mountain, under which it again fell sheer away down, down into misty depths, the bottom of which was hidden from sight. In all the galleries of memory I could find nothing resembling it." 1

The spires of rock range about 3300 feet high, jumbled together by nature in a sportive mood. Here and there, perched like nests of the solitary eagle, are the ruins of former hermitages, burnt by the French under Suchet in July 1811, when they amused themselves with hunting the hermits like chamois in the cliffs, hung the monks of the monastery, plundered it of all its contents, stripped the Virgin of her jewellery, and burnt the fine library. Hitherto the monks, when periodically dressing the image, had done so with modestly averted eyes, but Suchet's soldiers had no such scruples. This image had been entrusted in the ninth century to a hermit, Jean Garin. Now Riguilda, daughter of the Count of Barcelona, was possessed by a devil, in another word, crazy, and was sent to be cured by the image or the hermit. A temptation similar to that of S. Anthony followed, but with exactly the opposite result. To conceal his crime, Jean Garin cut off Riguilda's head, buried her, and fled. Overtaken by remorse he went to Rome, and confessed his sin to the Pope, who bade him become a beast, never lifting his face towards heaven until the hour when God himself would signify his pardon.

Jean Garin went forth from the Papal presence on his hands and knees, crawled back to Mon'serrat, and there lived seven years as a wild beast, eating grass and bark, and never looking up to heaven. At the end of this time

1 Taylor (B.), "Byways of Europe," Lond. 1869, i. p. 23.

216 


\section{ROCK HERMITAGES}

his body was entirely covered with hair, and it so fell out that the hunters of the Count snared him as a wild animal, put a chain round his neck, and brought him to Barcelona. Here an infant of five months old, on beholding the strange beast, uttered a cry and exclaimed, "Rise up, Jean Garin, God has pardoned thee." Then, to the amazement of all, the beast arose and spoke in a human tongue. Happily the story is no more true than that the image was made by S. Luke. It is an old Greek story of S. James the Penitent, with the penance of Nebuchadnezzar tacked on to it.

Forbes says: "The traveller should visit the ruined hermitages of Sta. Anna, San Benito, not forgetting La Roca Estrecha, a singular natural fissure; the highest and most interesting of all is the S. Jeronimo. 'These retreats satisfied the Oriental and Spanish tendency to close a life of action by repose, and atone for past sensualism by mortification. 'The hermitages were once thirteen in number; each was separate, and with difficulty accessible. The anchorite who once entered one, never left it again. There he lived, like things bound within a cold rock alive, while all was stone around, and there he died, after a living death to the world, in solitude without love. Yet they were never vacant, being sought for as eagerly as apartments in Hampton Court are by retired dowagers. Risco says that there were always a dozen expectants waiting in the convent the happy release of an occupant. To be a hernit, and left to live after his own fashion, exactly suited the reserved, isolated Spaniard, who hates discipline and subjection to a superior." 1

1 “"Handbook of Spain," Lond. 1845, p. 496. A risit to the image is heavily indulgenced. Pope Paul V. granted remission of all his sins to any one who entered the confraternity of our Lady of Montserrat. Mr. B. Taylor sars of the image: "I took no pains to get sight of the miraculous statue. I have already seen both the painting and the sculpture of S. Luke, and think him one of the worst artists that ever existed." 


\section{ROCK HERMITAGES}

Above Cordova, also in the Sierra, are rock hermitages serving in Andalusia the same purpose that did those of Montserrat in Catalonia. These also never wanted a tenant, for in the Iberian temperament, inedia et labor, violent action alternating with repose is inherent.

In Italy, Subiaco must not be left without a notice. It was hither that S. Benedict fled when aged fourteen. $\mathrm{He}$ chose a cave as his abode, and none knew what was his hiding-place save a monk, Romanus, who let down to him from the top of the rock the half of the daily loaf allotted to himself, giving him notice of its being ready for him by ringing a little bell. Here, once, troubled by the passions of the flesh, Benedict cast himself into a thicket of thorns, and afterwards planted there two rose-trees which still flourish. This is now converted into a garden, and near by all the monks of Subiaco are buried.

Near La Vernia, a favourite retreat of S. Francis, is a deep cleft in the rocks, and a cave to which he was wont to retire at times. One friar only, Brother Leo, was permitted to visit him, and that once in the day with a little bread and water, and once at night; and when he reached the narrow path at the entrance, he was required to say Domine labia mea aperies; when, if an answer came, he might enter and say matins with his master. In a second cave the saint slept. Outside this is the point of rock from which according to the Fiorette: "Through all that Lent, a falcon, whose nest was hard by his cell, awakened S. Francis every night a little before the hour of matins by her cry and the flapping of her wings, and would not leave off till he had risen to say the office; and if at any time S. Francis was more sick than ordinary, or weak, or weary, that falcon, like a discreet and charitable Christian, would call him somewhat later than was her wont. And S. Francis took great delight in this clock of his, because the great carefulness of the falcon drove away all slothfulness, and summoned him to prayers; 


\section{ROCK HERMITAGES}

and moreover, during the daytime, she would often abide familiarly with him."

The Warkworth hermitage in Northumberland was made famous by Bishop Percy's ballad.

In "Rambles in Northumberland and on the Scottish Border," 1835, it is thus described. "The hermitage of Warkworth is situated on the north bank of the Coquet, and about a mile from the castle. Leaving the castle yard and passing round the exterior of the keep, a footpath leads down the declivity on the north side of the river. Entering a boat and rowing a short distance along the river, the visitor is landed at the foot of a pleasant walk which leads directly to the Hermitage. This secluded retreat consists of three small apartments, hollowed out of the freestone cliff which overlooks the river. An ascent of seventeen steps leads to the entrance of the outer and principal apartment, which is about eighteen feet long, its width being seven feet and a half, and its height nearly the same. Above the doorway are the remains of some letters now illegible, but which are supposed when perfect to have expressed, from the Latin version of the Psalms, the words: Fuerint mihi lacrymæ meæ panes die ac nocte. The roof is chiselled in imitation of a groin, formed by two intersecting arches; and at the east end, where the floor is raised two steps, is an altar occupying the whole width of the apartment. In the centre, immediately above the altar, is a niche in which there has probably stood a figure either of Christ or of the Virgin.

"Near the altar, on the south side, there is carved in the wall a monumental figure of a recumbent female. In a niche near the foot of the monument is the figure of a man, conjectured to be that of the first hermit, on his knees, with his head resting on his right hand, and his left placed upon his breast. On the wall, on the same side, is cut a basin for the reception of holy water; and between the principal 219 


\section{ROCK HERMITAGES}

figure and the door are two small windows. At the west end is a third small window, in the form of a quatrefoil.

"From this apartment, which appears to have been the hermit's chapel, a doorway opens into the corner one, about five feet wide, and having also an altar at the east end, with a basin for holy water cut in the wall. In the north wall of this inner chamber an arched recess is cut, the base of which is of sufficient length and breadth to admit a middle-sized man reclining. An opening, cut slantwise through the wall dividing the chamber, allows a person lying in this recess to see the monument in the chapel. In the same wall there is rather an elegantly-formed window, which admits the light from the outer apartment. To the north of the inner chamber is a third excavation, much smaller than the other two, which led to an outer gallery to the west, commanding a view of the river. This gallery, which has been much injured by the fall of a part of the cliff; is said to have been arched like a cloister. After returning from these dimly-lighted cells to open day, and passing through a stone archway, a flight of steps cut in the side of the rock leads to the hermit's garden at the top."

$\mathrm{S}$. Robert of Knaresborough, who died 1218, was the son of one John 'Thorne of York, of which city his brother was mayor. Leland informs us that he forsook "the lands and goodes of his father to whom he was heire as eldest sonne." Leaving his home he came to Knaresborough, where he found a certain knight ensconced in a cave scooped out of the rock by the side of the Nidd, and dignified by the name of S. Giles's Chapel. But the knight had had enough of it, and instante diabolo quitted his cave and made it over to Robert Thorne, and "returned like a dog to his vomit," which is a monastic way of putting the fact that he returned to his wife and family.

Robert, however, did not spend an entire year in the cave, for certain latrunculi having stolen hys bred, hys chese, 220 


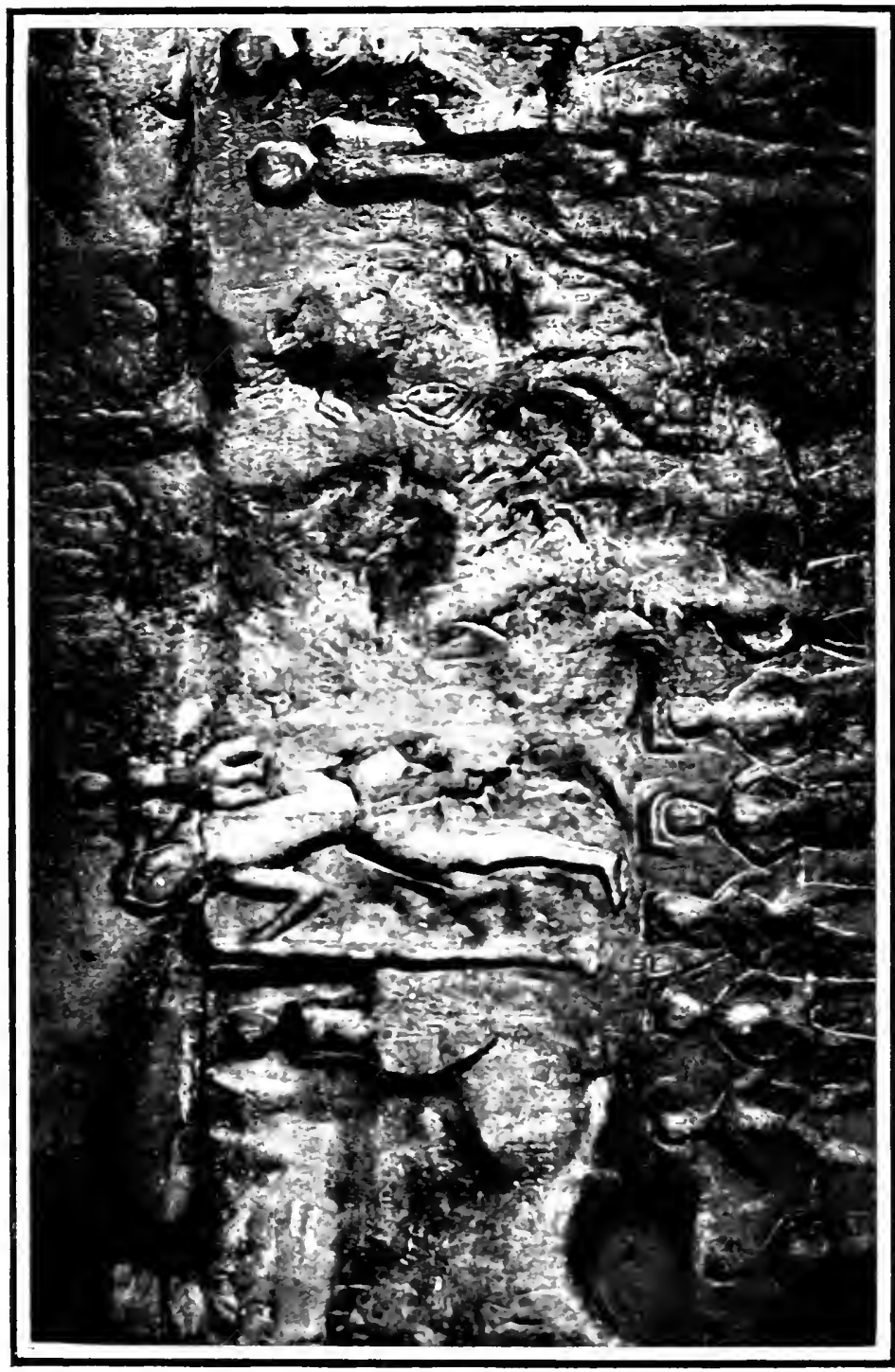

1 



\section{ROCK HERMITAGES}

hys sustenance, he quitted the grotto-doubtless at the approach of winter-and established himself in much more comfortable quarters at Bramham. He was certainly a hermit who boiled his peas, for we are told that he maintained four men-servants; two were occupied in tilling his farm, one attended to his personal wants-was, in fact, his valet-and one went about with him on his begging expeditions.

The cave is 10 feet long, 9 feet wide, and 7 feet high. There is an image of a knight at the entrance, by some supposed to be more modern; it is, however, said that S. Robert did much himself to adorn and enlarge his chapel.

It was in this cave that Eugene Aram and Richard Housman murdered Daniel Clarke on 8th February 1745, for the sake of some jewellery and plate they had induced him to bring to S. Robert's Chapel with him.

It was not till fourteen years after that the body of Clarke was found, and Mrs. Aram declared that her husband and Housman had murdered him; Housman turned King's evidence, and Aram was hung on 16th August 1759 .

Roche hermitage in Cornwall occupies a spire of rocks of schorl that shoots 100 feet above the surrounding moor. Built into the rocks is a little chapel, and beneath it is the hermit's cell. 'This seems to have been occupied continuously down to the Reformation, and various stories are told of the tenants.

There was once a steward under the Duchy named Tregeagle. He was a peculiarly nefarious agent, and very hard upon the tenants. His spirit is still supposed to roam over the moors, and not to be able to find peace till he has dipped the water out of Dozmare Pool with a nutshell.

Once, pursued by devils, he fled for sanctuary to Roche, and thrust his head through the east window of the chapel, 221 


\section{ROCK HERMITAGES}

but, being a broad-shouldered spirit, could force his way in no further. The devils were baffled and withdrew. But Tregeagle's position was not desirable. 'The wind, the rain, and the hail lashed that portion of his person that remained exposed, and he dared not withdiaw his head from sanctuary lest the devils should be on him again. At every cutting blast he howled, and his howls so disturbed the hermit of Roche, that he found it impossible to sleep or to attend to his prayers on windy nights. Unable to liberate Tregeagle himself, he sent for the monks of Bodmin, and they imposed on the wretched steward the task aforementioned, and assured him immunity from pursuit whilst engaged upon it.

"Robin Hood's Stable," in Nottinghamshire, at Pappewick, of which Throsby gives an illustration in his "History of the County," 1797, was in all probability a hermitage. Mr. W. Stevenson writes: "I am convinced, from its nearness to the great old road, its position due south, and its evidences of columns and arches, that it is an old cell or anchorite's cave of equal, if not superior age, to the neighbouring abbey. The interior would make a good picture, as the dampness of the rock is favourable to green vegetation in sportive lines and patches on the warm colours and the shadows of the rock. It is an artist's dream. Time, during the lapse of centuries, has made sad havoc with the entrance. Originally it had a level cutting running into the hill until a face of rock was won in which to make a door and hew an underground apartment.

"The hollow of this cutting has been raised, the banks rounded down, the roof over the door has fallen; the hand of destruction has worked back into the cave, and all evidence of the door and its whereabouts has vanished. The floor is loaded with sand and blocks fallen from the roof. The floor being so buried renders it difficult perfectly to judge of the depth of the apartment." What a habitation 222 


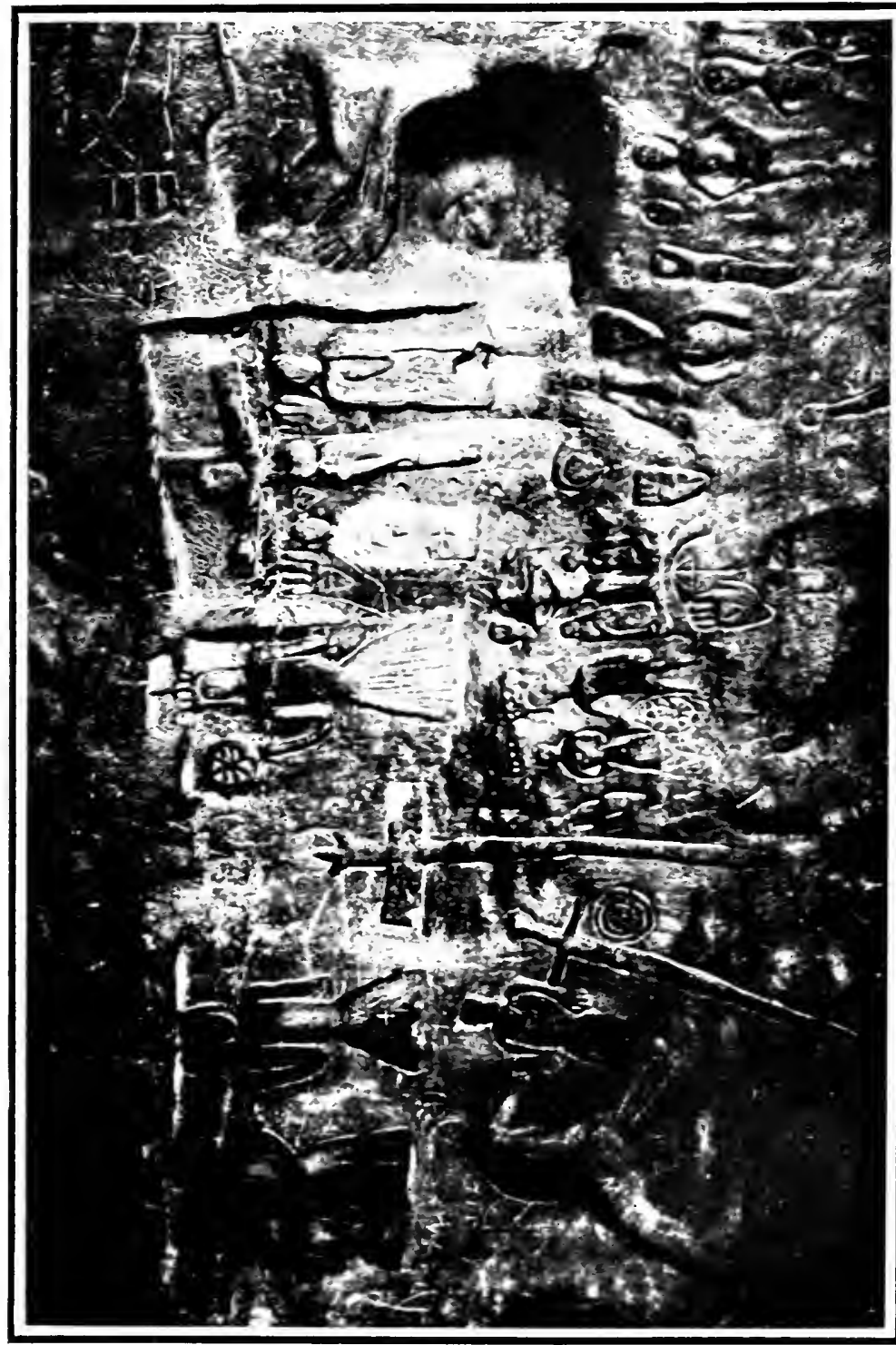





\section{ROCK HERMITAGES}

for a rheumatic hermit! The "sportive lines and patches" of vegetation suggest sportive tweaks and twinges of the loins.

Two miles from Repton is Anchor Church, where are the remains of a hermitage in a singular rocky bank, rising abruptly above the pastures on the verge of the Trent. "The summit is clothed with overhanging woods, forming only a portion of the high grounds, but the suddenness of the change which the scenery derives from the appearance of precipitous and broken rocks, occurring in the midst of a soft and beautiful region of pastoral luxuriance, is very striking. A curious series of chambers, communicating with each other, has been at some distant period beyond tradition excavated in that portion of the rock which is most naked and precipitous; and from this circumstance the site has been designated Anchor Church, signifying the residence of a hermit. At a distance it bears a very close resemblance to a Gothic ruin; the rude openings formed to admit light into the several cells, and the ruggedly fashioned doorway aiding, at first sight, the appearance of an artificial pile of grey antiquity. The rock is found principally to consist of rough grit-stone, and of a congeries of sand and pebbles. 'The Trent, which now flows at a short distance, formerly ran close under the rock, as is indicated by a dead pool of water situate near its foot, and communicating with the channel of the river.

"A tall flight of steep steps rudely fashioned of large unshapen blocks of stome, conducted to the entrance of the hermitage, and the dim light within its hoary, mossgrown, sloping walls is admitted through irregularly formed apertures, pierced through the dense body of the rock, and command magnificent views of the subjacent scenery." 1

In the month of August 1742, when occasion arose for

1 Bigsby (R.), "Historical and Topographical Description of Reptoc in the County of Derby," Lond. 1854. 


\section{ROCK HERMITAGES}

setting a post in a "Mercat House" at Royston in Hertfordshire in order to place a bench on it for the convenience of the market women, the men in digging struck through the eye or central hole of a millstone, laid underground, and on raising this found that it occupied the crown of a cave sixteen feet deep, as appeared by letting down a plumb line. There was a descent into it of about two feet wide, with holes cut in the chalk at equal distances, and succeeding each other like the steps of a ladder. It was accurately circular. They let a boy down, and from his report of its passing into another cavity, a slender man with a lighted candle descended, and he confirmed the report, and added that the second cave was filled with loose earth, which, however, did not quite touch the wall, which he could see to right and left.

The people now conceived the notion that a great treasure was concealed here, and some workmen were employed to enlarge the passage of descent. Then with buckets and a well-kerb, they set to work to clear it, and drew up the earth and rubbish that filled the cave. When they came to the floor of the descending passage they ran a long spit downwards and found that the earth was still loose. The vast concourse of people now became troublesome, and the workmen were obliged to postpone further operations till night.

After much time and labour had been expended, the cave was cleared, but no really scientific examination of it was made till 1852, when Mr. Beldam drew up a report concerning it, which he presented to the Royal Society of Antiquaries. The cave is bell-shaped, and from the floor to the top of the dome measures $25 \frac{1}{2}$ feet. The bottom is not quite circular, but nearly so, and in diameter is from 17 feet to 17 feet 6 inches. A broad step surrounds it, 8 inches wide and 3 feet from the floor. About 8 feet above 224 


\section{ROCK HERMITAGES}

the floor a cornice runs round the walls cut in a reticulated or diamond pattern two feet wide. Almost all the space between the step and this cornice is occupied with sculpture, crucifixes, saints, martyrs, and subjects not easy to explain. Vestiges of red, blue, and yellow are visible in various places, and the relief of the figures has been assisted by a dark pigment. In various parts of the cave, above and below the cornice, are deep cavities or recesses of various forms and sizes, some of them oblong, and others ovenshaped, of much the same character as those found in the French cares. High up are two dates cut in the chalk, in Arabic numerals, that have been erroneously read $134 \%$ and "Martin 1350 February 18," but these should be respectively 1547 and 1550 , as Arabic numerals were not in use in England in the fourteenth century, and the name of Martin and the February are distinctly sixteenth century in character. The figure carving was not done by the same hand throughout.

Apparently the cave was originally a shaft for burial or for rubbish, and a hole in the side and floor that Dr. Stukeley took for a grave was nothing but a continuation downwards of the ancient shaft, as is proved by what has been found in it. But in mediæval times the puticolus was enlarged and converted into a hermitage, and a hermit is known to have occupied it till the eve of the Reformation, for in the Churchwarden's book of the parish of Bassingborne, under the date 1506, is the entry, "Gyft of 20 d. recd. off a Hermytt depting at Roiston in ys pysh." It is true that this entry does not absolutely fix the residence of the hermit at the cave, but it is hardly probable that there were two hermitages in so small a town.

The cave was probably filled in with earth in $154 \tau$ and 1550, when the inscribed dates were affixed. After which its existence was forgotten, and the Mercat House was 225 


\section{ROCK HERMI'TAGES}

erected over it before 1610. The carvings have been supposed to belong to the period of Henry II. and Richard Cour-deLion, but it is not possible to put them earlier than the beginning of the sixteenth century, at all events such as represent the Crucifixion. It is possible, however, that some of the kingly or knightly figures may be somewhat earlier.

Stukeley was quite convinced that the Royston cave was the oratory of the Lady Rohesia, daughter of Aubrey de Vere, who succeeded his father in 1088, but there exists no evidence that she ever lived at Royston. The place takes its name from Rohesia, daughter of Eudo Dapifer.

In 1537, says Froude, while the harbours, piers, and fortresses were rising in Dover, "an ancient hermit tottered night after night from his cell to a chapel on the cliff, and the tapers on the altars before which he knelt in his lonely orisons made a familiar beacon far over the rolling waters. The men of the rising world cared little for the sentiment of the past. 'The anchorite was told sternly by the workmen that his light was a signal to the King's enemies" (a Spanish invasion from Flanders was expected), "and must burn no more; and when it was next seen, three of them waylaid the old man on his way home, threw him down, and beat him cruelly." 1

The following notice appeared in the Daily Express of 9th June 1910. "A subterranean chamber with a spiral staircase at one end and a Gothic roof has been discovered at Greenhithe. It is believed to have been a hermit's cell."

The hermit left a pleasant memory behind him when he disappeared from England, perhaps just in time before complete degeneration set in as in France and Germany, Italy and Spain. Shakespeare, whenever he introduces him, does so in a kindly spirit, and represents him as a consoler 


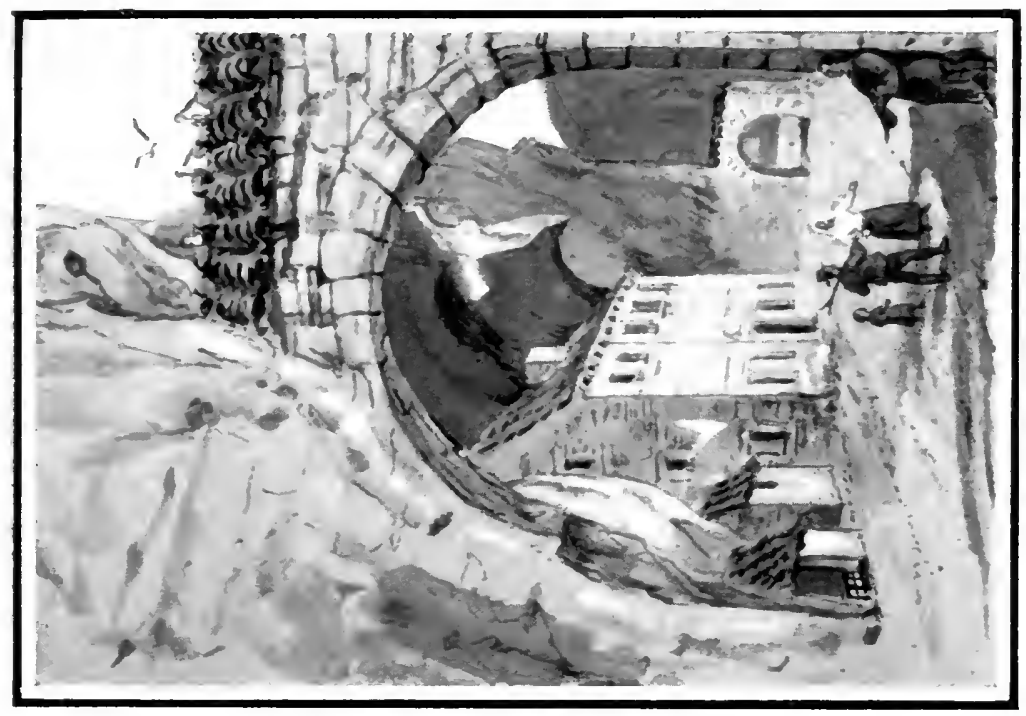

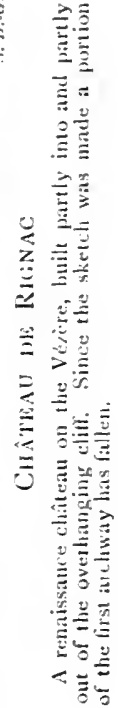
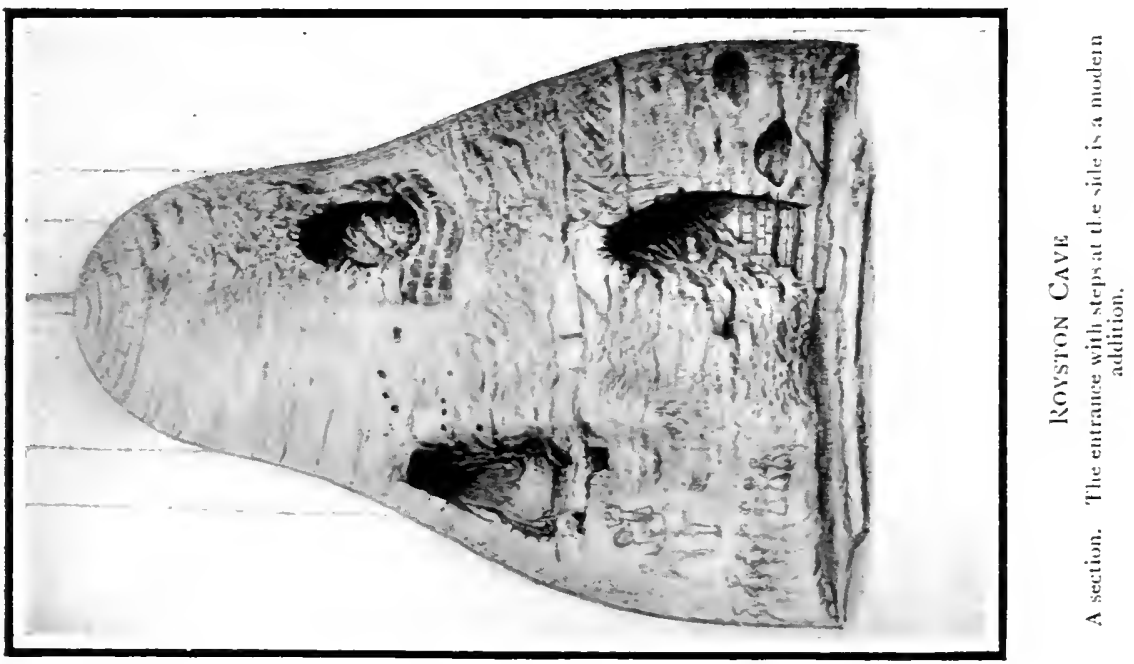



\section{ROCK HERMITAGES}

of the afflicted and a refuge to the troubled spirit. By Spenser also he is treated with affection.

"Towards night they came unto a plaine

By which a little hermitage there lay,

Far from all neighbourhood, the which annoy it may.

And nigh thereto a little chappel stoode,

Which being all with ivy overspred

Deckt all the roofe, and, shadowing the roode,

Seem'd like a grove faire braunched over hed :

Therein the hermit, which his life here led

In streight observance of religious vow,

Was wont his hours and holy things to bed;

And therein he likewise was praying now,

Whenas these knights arrived, they wist not where nor how."

I do not recall any harsh words spoken of the departed hermit. After the Reformation it was felt that a factor in life was gone that could be ill spared.

In these days when we live in a hurricane of new ideas, in the stress of business, we cannot understand the attractiveness of the peace of a cell away from the swirl of the storm, or the value of the hermits as guides of life. When the hermit was swept away, into his place as counsellor of the troubled stepped the witch, and to her those had recourse who had previously sought the eremite. The influence of the witch was always for evil, that of the hermit was usually good. The troubled soul desires a confidant and an adviser. The parish priest is not always spiritually minded, and is not always disinterested. What is hid from the wise and prudent is revealed to babes, and for the guidance of distracted consciences, the healing of wounded spirits, the words of the childlike hermit were a boon. However, he is gone past recall, and into his room have stepped the lawyer who demands six-and-eightpence for a word of advice, and the doctor whose charges are proportionate to the rental of our houses. 


\section{CHAPTER IX}

\section{ROCK MONASTERIES}

$\mathrm{T}$

HE early Syrian and Egyptian hermits would have become a sect of manichæan heretics but for the popularity of the profession and the Arian persecution. In quitting the world they cut themselves off from the churches. They no more took part in its assemblies, participated in the sacraments, nor observed the sacred seasons. Paul, the first hermit, deserted the society of men when aged fifteen, and lived till the age of a hundred and ten in solitude without ever having partaken of the Bread of Life. S. Mary of Egypt spent forty-seven years in the Wilderness, stark naked, covered with hair like a wild beast, and only received the Viaticum when dying, by the chance of a priest passing that way. A fifteenth century statue of her, nearly life-size, is in the National Museum at Munich, removed from the Cathedral of Augsburg as indelicate. S. Antony spent twenty years in a sort of cistern, and only twice a year received loaves, let down from above through the roof. Certainly all that time he was voluntarily excommunicate. If $\mathrm{S}$. Hilarius ever made sacramental communion we are not told, but we do know that he was for ever hiding himself from where were his fellow-men, in wilds and loases, and where there were no Christian churches.

In the desert, times and seasons slipped away, and became confounded, so that by the first hermits neither Easter nor the Lord's Day were observed. In the Gospel, the works of mercy, feeding the hungry, giving drink to the thirsty, clothing the naked, visiting the sick and prisoners, are 228 


\section{ROCK MONASTERIES}

appointed as the means of deserving a reward in heaven, but the anchorites neglected every one, cut themselves adrift from the chance of performing them, and sought to merit heaven in their own way. Christ declared, "Except ye eat the flesh of the Son of Man, and drink His blood, ye have no life in you," but they wilfully lived apart from the sacramental life as surely as any modern Quaker.

But when crowds of refugees from the duties and pleasures of life sought the desert, they ceased to be solitaries, and organisation on a monarchical system under an abbot became necessary; and when bishops and priests fled to them, or were banished and sought them, during the Arian persecution, they came to plume themselves as champions of orthodoxy, and conformed to Catholic usage, assembling on the Lord's Day for prayers and the Eucharist. When the fashion set in for deserting the world, floods of men, women, and children threw themselves into it, and flowed into the desert during a century with resistless force. Pachomius, who died at fifty-six, reckoned three thousand monks under his rule; the monasteries of Tabenna soon included seven thousand, and S. Jerome affirms that as many as fifty thousand were present at the annual gathering of the general congregation of monasteries that followed his rule.

There were five thousand on the mountain of Nitria; near Arsinoë the Abbot Serapion governed ten thousand. It has even been asserted that there were as many monks in the deserts of Egypt as inhabitants in the towns. The immense majority of these religious were cenobites; that is to say, they lived in the same enclosure, and were united under an elected head, the abbot. The cenobitical life rapidly and necessarily superseded that of the solitary. In fact the monks were now no more solitaries than are the jackdaws in a cleft, or the bees in a hive, but unlike the jackdaws, they were under discipline, and unlike bees were without a sting.

It was not mere love of an indolent life and a desire to 229 


\section{ROCK MONASTERIES}

escape from military service that swelled the numbers in the desert. The condition of the decaying Roman world led men to despair of the Commonwealth, and of the possibility of their being able to save their own souls in the midst of the general corruption. "The people were exhausted by compulsory taxes, to be spent in wars which did not concern them, or in Court luxury in which they had no share. In the municipal towns liberty and justice were dead. The curials, who were responsible for the payment of the public moneys, tried their best to escape the unpopular office, and when compelled to serve wrung the money in self-defence out of the poorer inhabitants by every kind of tyranny. Private profligacy among all ranks was such as cannot be described in any modern pages. The regular clergy of the cities were able to make no stand against the general corruption of the age because-at least if we are to trust such writers as Jerome and Chrysostom - they were giving themselves up to ambition and avarice, vanity and luxury; and, as a background to all these seething heaps of decay, misrule and misery, hung the black cloud of the barbarians, waxing stronger and stronger so that the wisest Romans saw clearly as the years rolled on, they would soon be the conquerors of the Cæsars and the masters of the Western world.

"No wonder, if in such a state of things, the minds of men were stirred by a passion akin to despair, which ended in a new and grand form of suicide. It would have ended often, but for Christianity, in such an actual despair as that which had led in past ages more than one noble Roman to slay himself, when he lost all hope for the Republic. 'That the world-such at least as they saw it then-was doomed, Scripture and their own reason taught them. They did not merely believe, but saw, in the misery and confusion, the desolation and degradation around them, that the world was passing away, and the lust thereof, and that only he who did the will of God could abide for ever. 'They did not merely 


\section{ROCK MONAS'TERIES}

believe, but saw that the wrath of God was revealed from Heaven against all unrighteousness of men. Under these terrible forebodings, men began to flee from a doomed world, and try to be alone with God, if by any means they might save each man his own soul in that dread day." 1

In the year 336 Athanasius was in exile at Trères. He is traditionally held to have there occupied a cave beyond the Moselle. The Bishop Maximinus received him with honour. Early in his episcopate Athanasius had visited the congregation of monks on the Upper Nile, and he was enthusiastic in his admiration of their mamner of life. It is supposed that whilst at Trèves he began to write the "Life of S. Anthony," if indeed he was the author of that popular work. Here he is thought to have been visited by Maxentius, Bishop of Poitiers, and brother of the Bishop of 'Irèves, bringing with him Martin, then a friend and pupil of $S$. Hilary, this latter at the time a wealthy noble of Poitiers. And from the discourse of Athanasius, if this meeting actually took place, the imagination of Martin was fired with ambition to reproduce in Europe the life of the fathers of the desert in Egypt.

Anyhow, to this residence of Athanasius at Trèves, "one may trace the introduction into the Western Church of the principle and laws of ascetic self-renunciation, which, though they had run to great extremes in the Nitrian desert and in the valley of the Nile, assumed noble form when the idea took possession of the more phlegmatic temperament and practical energies of the West. Without discussing the rexed question of the authorship of the 'Life of S. Anthony,' which is referred by many traditional testimonies to Athanasius, we think it obvious, from the 'Confessions' of Augustine, that the religious circles at 'Trèves had been strongly moved by the self-abandonment and entire consecration to the religious life of the exiled bishops. It was here, while

1 Kingsley (C.), "The Hermits," Lond. 1868.

231 


\section{ROCK MONASTERIES}

reading the 'Life of $S$. Anthony' that the friends of Augustine at length yielded themselves to God." 1

Martin was at Poitiers in 361 when S. Hilary had returned from exile to his bishopric and to his wife and daughter. He had been living the eremitic life on the isle of Gallinaria, shaped so like a suail, off the coast of Albenga, and had nearly poisoned himself with trying to eat hellebore leaves. On reaching Poitiers, he told his old friend the Bishop, that he desired to follow the monastic life in his diocese, and obtained his cheerful consent. Some way up the Clain, five miles from Poitiers, the little river glides through a broad valley, with meadows on its left bank often overflowed, but with a ridge of conglomerate rocks pierced with caves on the right bank. Here Martin settled, and there can exist no manner of doubt that his first settlement was in one of these grottoes, though at a later period the monastery was moved to the further side of the river, when the caves proved inadequate to harbour all the candidates for the religious life who placed themselves under his direction. One of his monks, however, named Felix, refused to quit his cave that is now shown, and in which he died perhaps, in an inaccessible cliff that is surmounted by a cross.

The friable conglomerate has yielded to storm and rain, and much of it has crumbled down; but the openings to the caves are visible from below, where the slopes are purple and fragrant with violets and, later, pink with primulas, and the rocks are wreathed with clematis. A pure spring bursts forth at the foot and works its way through beds of forget-me-not and marsh marigold to the Clain.

Martin had been ordained exorcist and then priest.

His most trusted disciples were Felix, Macarius, and Florentius. As already said, except in the Gallo-Roman cities, Christianity did not exist. 'The country-folk were

1 Reynolds (H. R.), "Athanasius, his Life and Life-work," Lond., R.T.S., 1889, p. 54. 


\section{ROCK MONASTERIES}

pagans. Martin lifted up his eyes and saw that the fields were white to harvest. He preached throughout Poitou and La Vendée, and visited the coast to the isles of Yeu and Ré. He travelled on foot, or mounted on an ass, sought every village and hamlet, to sow the seed of the Word of God, and where he could not go himself, he sent his disciples. Ligugé, his monastery, became a centre of evangelisation to the country round. It was the first monastery planted on Gaulish soil. It was ruined by the Saracens in 732, and again by the Normans in 848 . It was rebuilt in 1040. But Ligugé never had a worse enemy than one of its abbots, Arthur de Cossé. He made public confession of Calvinism; gave up the abbey to be pillaged, sold its lands for his own advantage, and did everything in his power to utterly ruin it. It owed its restoration to the care of François de Servier, Bishop of Bayonne.

Ligugé was, however, destroyed at the French Revolution. In 1864 it was acquired by the Benedictines, and rebuilt on a large scale. It was enriched with a valuable library, and became a nursery of Christian art and literature. But the law of 1901 banished the monks, and the vast building is now empty, as the State has not so far found any use for it.

In the year 971 the episcopal throne of Tours was vacant, and the citizens at once decided on securing Martin as their bishop. But when he arrivel on foot, dust-covered, with shaggy hair, the bishops assembled to consecrate protested against the election. It was customary to choose a bishop from among the nobility and the wealthy. Defensor, the Bishop of Angers, signalised himself by his opposition. He absolutely refused to consecrate the poor dishevelled monk. But when the lector opening the psalter at hazard read out the words, "Out of the mouths of babes and sucklings hast thou ordained strength, because of thine enemies : that thou mightest still the enemy and the defender " (defensor), ${ }^{1}$ the

1 So in the old Gallican Version; in the Vulgate the word is $l$ "ltor. 


\section{ROCK MONASTERIES}

people raised a great shout, God himself had spoken, and the bishops had to yield to the popular will. Martin was then aged fifty-four.

No sooner was he installed than he cast about him to establish on the banks of the Loire a monastic colony such as he had founded at Ligugé. He found a place where in later times rose the great abbey of Marmoutier, the wealthiest in France, and with a church that was called the Gem of Touraine. But then it was merely a chalk cliff rising above the Loire on its right bank, two miles above 'Tours, and on the summit had stood the old Gaulish city of Altionos. The Romans had transferred the capital of the Turones to its present site, and had given it the name of Cæsarodunum. But Althionos was probably not wholly abandoned, poor Gauls still dwelt there in their huts, and nothing had been done to bring them into the fold of Christ's Church.

The cliff with its caves had already been sanctified. It had been a refuge in time of persecution, and there S. Gatianus, the first Bishop of Tours, in the third century had sheltered. But now Martin and his disciples set to work to enlarge and remodel the subterranean habitations; they scooped out a chapel, and they formed a baptistry.

In 853 the Northmen came up the Loire and massacred a hundred and sixteen of the monks. Only twenty-four escaped. In 982 Marmoutier was refounded by Eudo, Count of Blois, and the noble basilica built below the rock was consecrated by Pope Urban II. in 1095. The vast wealth of the abbey led to enlargements and splendour of architectural work; but in $\mathbf{1 5 6 2}$ the Huguenots wrecked it, burned the precious library with all its MSS., broke down the altars, and shattered the windows. Its complete destruction, however, was due to the Revolution, when in 1791 it was completely pulled down, nothing left of the splendid church but the tower and a portion of the northern transept 234 


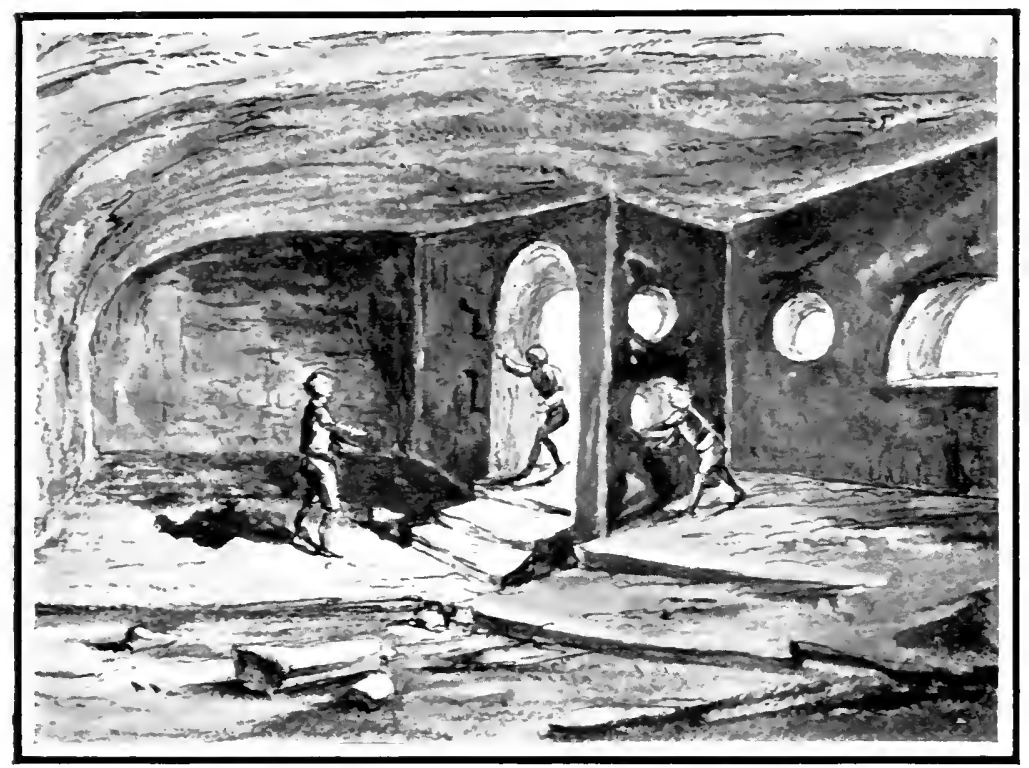

LE TROC BOCROC

A cave fortress on the Beune. The hole through which the man is prering was used for defence of the steep ascent to the eatrance. Note the arrangement for barring the door.

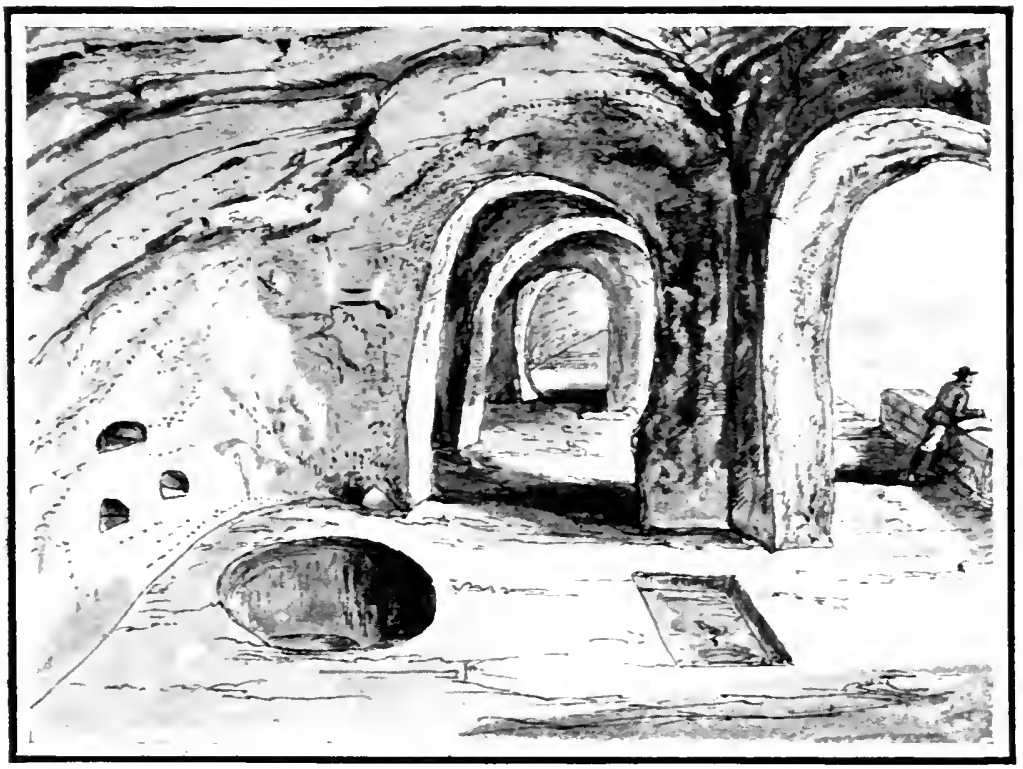

Rock Baptistery of S. Martis, Marmoutier

Excavated and occupied by S. Martin. Bishop of Tours, A.D. 371-396. On the right-hand side is the well, on the left the funt for immersion. The niches in the wa!l are for the boly oils. 


\section{ROCK MONASTERIES}

that was glued to the rock. The oratory of S. Martin was levelled to the rock on which it stood.

But the fact of the transfer of the monastery to the flat land below the cliff had this effect, that the old caves, the original cradle of Marmoutier, were neglected and forgotten. 'They were overgrown by brambles, crumbled away, and none visited them.

In 1859 the oratory in which S. Martin had prayed was restored or rather rebuilt from its foundations.

One night when Martin was engaged therein in reading the Scriptures, the door was burst open and in broke a party of masqueraders. They had disguised themselves as Jupiter, Minerva, and Mercury, and some damsel devoid of modesty presented herself before the startled modesty of the bishop without disguise of any sort, as Venus rising from the foam of the sea. Some were dressed as Wood Druses very much like the devils of popular fancy. Mercury was a sharp, shrewd wag, and bothered the saint greatly, as he admitted to Sulpicius, his biographer, but Jupiter was a "stupid sot." At the rebuke of Martin the whole gang good-humouredly withdrew.

I was in this cell on Mid Lent Sunday, when hearing a noise outside, I looked forth and saw a party of masqueraders frolic and frisk past on their way to a tavern where was to be a costume ball. So goes the world. Some fifteen hundred and thirty years ago the Gospel was being preached in Tours, as it is now, men and women were striving to follow its precepts as now, and tomfoolery was rampant in Tours fifteen hundred and thirty years ago as it is now.

And now, as to the remains in the rock of the primitive Marmoutier. The grottoes of S. Gatianus and of the disciples of S. Martin have been cleared out. There is a little arcade of three round-headed unadorned arches cut in the cliff that served as a cloister, and there is the old baptistry where Martin admitted his converts into the 235 


\section{ROCK MONASTERIES}

Christian Church, sunk in the rock for adult and complete submersion, and the niches in the wall for the sacred oils. Adjoining is the cave in which the neophyte unclothed and afterwards reclothed himself. There are graves sunk in the rock, where some of his disciples were laid, and there is the chapel partly in the rock and partly rebuilt, dedicated later by Gregory of 'Tours to the Seven Sleepers of Ephesus, but of which in after times a different story was toldnamely that seven brothers who had been devoted disciples of Martin prayed him when he was dying that they might speedily follow, and on the anniversary of his death they all seven fell asleep.

There is another cave that escaped destruction at the Revolution, though opening out of the transept of the church. It is that of the Penitence of Brice.

Brice had been adopted as a child by Martin, and brought up by him to be a monk. But Brice had no liking for the religious life, and was very disrespectful to his master. One day a sick man came to see Martin and asked of Brice where the saint was. "The fool is yonder," answered he, "staring at the sky like an idiot."

One day Martin rebuked Brice for buying horses and slaves at a high price, and even providing himself with beautiful young girls. Brice was furious, and said. "I am a better Christian than you. I have had an ecclesiastical education from my youth, and you were bred up amidst the license of a camp."

On the death of S. Martin, the people of Tours, tired of having a saint at their head, with proverbial fickleness chose Brice as his successor because rich-he was said to have been the son of the Count of Nevers-and because he was anything but a saint. As bishop he showed little improvement, and gave great scandal. Lazarus, Bishop of Aix, accused him before several councils. At last a gross outrage on morals was attributed to him, and caused his 236 


\section{ROCK MONASTERIES}

flight. A nun gave birth to a child, and confessed that she had been seduced by the bishop. Brice either ran away from Tours or was deposed. A priest named Justinian was elected in his room. On the death of Justinian, Armentius succeeded him. Brice remained in exile till the death of Armentius, and then ventured back to Tours to reclaim his episcopal throne. He was allowed to reascend it, and he occupied it for seven years; and the cave in which he did penance for his frailties and the scandal he had caused is intact to this day. He died, after having been nominally bishop for forty-seven years, the greater portion of which time he had spent in exile. The Church of Rome is certainly very charitably disposed in numbering him among the saints. Why he should be regarded as the patron of wool-combers one cannot see, ${ }^{1}$ but as such he enjoyed some popularity.

There is yet another cave in the Marmoutier rocks that may be mentioned; it is that of S. Leobard. Leobard was a saint of the sixth century, a native of Auvergne, who, coming to pray at the tomb of S. Martin, resolved on spending the rest of his days in one of the cells of Martin's monastery in the rocks. He settled into an untenanted cave, which he enlarged, and lived in it for twenty-two years. At the extremity he dug a deep pit in which he desired to be buried standing with his face to the East, thus to await the coming of the Lord. But although his desire was fulfilled, the monks of Marmoutier would not let his body rest there, but hauled it up, that it might become an object of derotion to the faithful.

1 The following prayer is recommended by the Archbishop of Tours to the faithful for use. "Nous rous supplions, Seigneur, par l'intercession de S. Brice, Evèque et Confesseur, de conserver votre peuple qui se confie en rotre amour; afin que, par les vertues de notre Saint Pontife, nous méritions de partager avec lai les joies celestes." The virtues of Brice! 


\section{ROCK MONAS'IERIES}

The Abbey of Brantôme on the Dronne (Dep. Dordogne) was originally, like Marmoutier, a cavern monastery, and like those of Marmoutier, the monks waxing fat, they kicked and abandoned the grottoes for a stately structural monastery. The beautiful Romanesque tower of the church stands on top of a rock that is honeycombed with their cells. The church, consisting of nave only, is of marvellous beauty, early pointed, and built on a curve, as there was but little space to spare between the river and the cliffs. Unhappily church and cloister were delivered over to be "restored" by that arch-wrecker, Abbadie, who has done such incalculable mischief in Perigord and the Angoumois, and his hoof-mark is visible here. 'The monks, not content with a sumptuous Gothic abbey, pulled it down and built one in the baroque style, and had but just completed it when the Revolution broke out "and the flood came and swept them all away." In the court behind this modern structure is to be seen the cliff perforated with caves; it has, however, been cut back to the detriment of these, so that we have them shorn of their faces. Nevertheless they are interesting. The old monolithic chapel of the monastery remains, turned into a pigeonry, and with the steps left that gave access to the pulpit, and two pieces of sculpture on a very large scale, cut out of the living rock. One represents the Crucifixion with SS. Mary and John; the other has been variously explained as the Last Judgment or the Triumph of Death. It perhaps represents the 'Triumph of Christ over Death. His figure and the kneeling figures of His Mother and the Beloved Disciple were, however, never completed, and remain in the rough.

Beneath the figure of Christ is Death, figured by a head surmounted by a crown of bones, and a crest representing a spectre armed with a club. On each side is an angel blowing a trumpet. Below are ranged a dozen heads of 238 


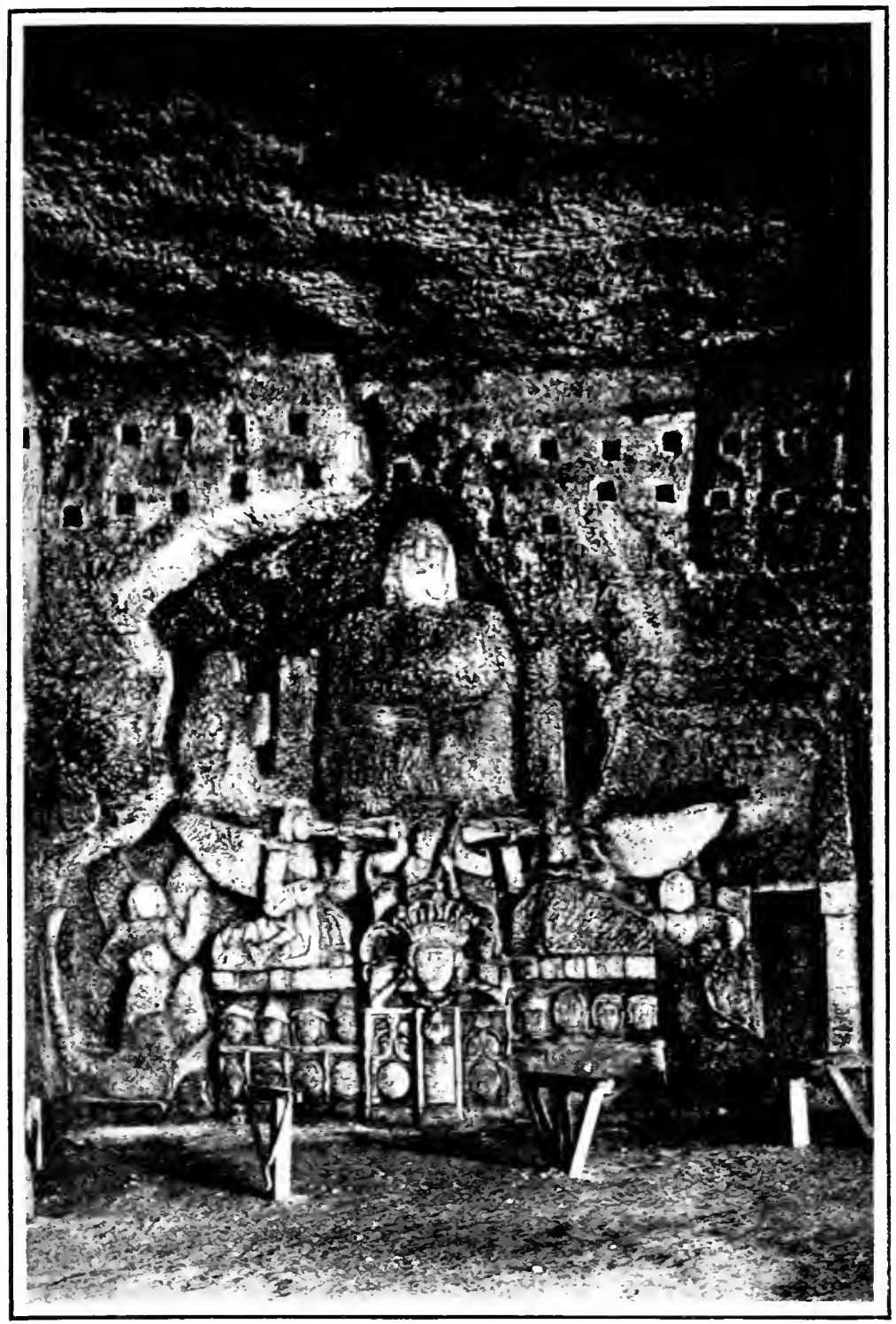

The TRIUMPh OF Christ ONER DeAth

Sculpture in the cave monastery of Brantime. The figure of Chrivt was never completed. Below is a head urowned with bones, for Death, with Tine as crest. Below. in boxes, are the dead, of various dezrees. 


\section{ROCK MONASTERIES}

popes, bishops, princes, knights, and ladies, in boxes to represent graves.

In the front of this huge piece of sculpture are trestles planted in the ground to support planks to serve as tables when the Brantômois desire to have a banquet and a dance.

The sculpture above described is not earlier than the sixteenth century. A few paces from it, in the same line and almost under the tower, is another grotto called $L a$ Babayou-that is to say "of the statue," and it probably at one time enshrined an image of a saint. On the left of the subterranean church is the fountain of the little Cut-throat already mentioned. S. Sicarius, whose relics were the great "draw" to Brantôme in the Middle Ages, was supposed to have been one of the Innocents slain by Herod; and the relics were also supposed to have been given to the abbey by Charlemagne. As there was no historic evidence that Charles the Great ever had a set of little bones passed off on him as those of the Innocent, or that he ever made a present to the abbey of a relic, it will be seen that a good deal of supposition goes to the story. As I have said before, how it was that the child of a Hebrew mother acquired a Latin name, and that one so peculiar, we are not informed.

Outside the town gate are other large excavations that are supposed to have formed a temple of Mithras, but this is mere conjecture. The largest is now employed as a Tir-a shooting gallery. That there were buildings connected with it is seen by the holes in the rock to receive rafters.

S. Maximus, Bishop of Riez, who died in 460 , was born at Château Redon, near Digne, and he entered the monastic life on the isle of Lerins, under S. Honoratus, and when that saint was raised in 426 to the episcopal throne of Arles, Maximus succeeded him as Abbot of Lerins. But this monastery was becoming crowded, and Maximus pined 239 


\section{ROCK MONASTERIES}

for the solitary life, so one day he took a boat, crossed to the mainland, and plunged into the wild country about the river Verdon, that has sawn for itself a chasm through the limestone; where it debouches, he planted himself at a place since called Moustier-Ste-Maric. The lips of the crevasse are linked by a chain, with a gilt star hanging in the midst, little under 690 feet above the bed of the torrent. No one knows when this star was hung there, but it is supposed to have been an ex voto of a chevalier, de Blac. Within the ravine, reached by a narrow goatpath, were caves in the cliffs, and into one of these Maximus retired in 4:34 and was speedily followed by other solitaries. The caves are still there, the faces walled up, but as at Ligugé, and as at Marmoutier, and as at Brantôme, so was it here. As the monastery grew rich, the solitaries crawled out of their holes into which the sun never shone, and erected their residence at the opening of the ravine. A chapel remains, founded by Charlemagne, but rebuilt in the fourteenth or fifteenth century, reached by a stair protected by a parapet.

Moustier was famous at the close of the seventeenth and beginning of the eighteenth century for its faience, with elegant designs and good colouring. Specimens are now extremely scarce. 'Two vases of this ware may be seen on the altar of the chapel. The principal potters there were Pierre Fournier, Joseph Olery, Paul Rouse, and Féraud. They usually signed their work with their initials. Maximus was just a century later than Martin; the fever for imitating the lives of the Fathers of the Deserts of Egypt was then in full heat. His master, Honoratus, had been wont to escape from his island monastery and hide in a cave in the glowing red porphyry rocks of the Esterelle. I can understand his retiring thither, above a sea blue as the neck of a peacock, among glowing red rocks, and masses of pines, and heather, and arbutus, and every kind of fragrant 240 


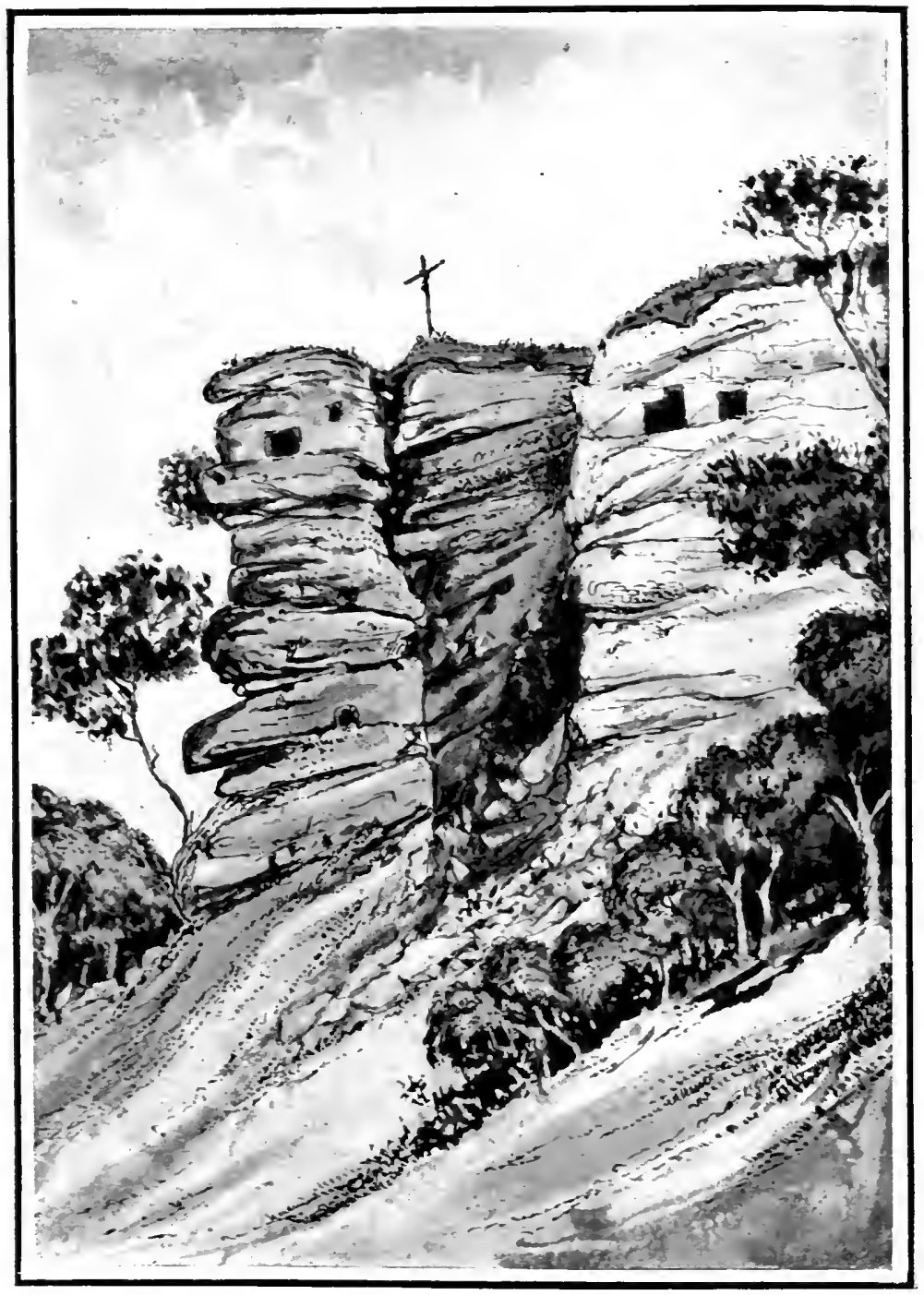

CAVES OF Ligug's

$5, B . G$.

The primitive rock monastery of S. Martin. It was abandoned later when the monks moved to the further side of the river; but Felix, a disciple of S. Martin, remained and died in the cave, now inaccessible, below the cross. 



\section{ROCK MONASTERIES}

herb, and where, when only snowdrops are appearing in England, the spires of white asphodel are basking in the sun.

Near Nottingham are the "Popish Holes," close to the river Lene. They are thus described by Stukeley. "One may easily guess Nottingham to have been an ancient town of the Britons; as soon as they had proper tools they fell to work upon the rocks, which everywhere offer themselves so commodiously to make houses in, and I doubt not first was a considerable collection of this sort. What is visible at present is not so old a date as their time, yet I see no reason to doubt but it is formed upon theirs. There is a ledge of perpendicular rock hewn out into aychurch, houses, chambers, dove-houses, \&c. The church is like those in the rocks of Bethlehem and other places in the Holy Land; the altar is natural rock, and there has been painting upon the wall, a steeple, I suppose, where a bell hung, and regular pillars. The river winding about makes a fortification to it, for it comes at both ends of the cliff, leaving a plain in the middle. The way into it was by a gate cut out of the rock, and with an oblique entrance for more safety. Without is a plain with three niches, which I fancy their place of judicature, or the like. Between this and the castle is a hermitage of like workmanship."

These remains pertain to a cell called S. Mary le Rock, a quarter of a mile west of the Castle, and belonged to Lenton priory. It was abandoned after the time of Edward IV., and is supposed to have come down in a perfect form to the time of the Civil War, when it was much injured by the Puritans as Papists' holes. A good many illustrations exist of it after the Civil Wars, as a large folding plate in 'Throsby's and Thoroton's "History of Nottinghamshire," 179\%, but there is none to show what it was before.

It possesses a pigeonry much like that at Brantôme, but on a smaller scale, that wiseacres have pronounced to be a 


\section{ROCK MONAS'IERIES}

Columbarium, not for doves, but for the reception of jars containing the ashes of the dead, and have attributed this dovecote to Roman times. Mr. William Stetton, a local antiquary, writing in 1806, stated that the excavation " appeared to have been made in the earliest ages of Christianity, when the converts resorted for secrecy and security to grottoes or caves, and similar places of retirement and seclusion. The style is evidently Roman. 'The whole interior appears to have been invested with a thin plastering, or perhaps, only a wash, which has been painted in various colours in mosaic devices. 'The altar still remains pretty perfect notwithstanding the ravages of time and wanton depredation. A Roman column still adorns the north side of it, but its corresponding one on the south side has long been destroyed."

An architect, John Carter, in the Gentleman's Magazine for 1860, stated that the "arrangements of the excavations are monastical; and we, with much satisfaction, trace out the infirmary, refectory, dormitory, chapter-house, and the chapel. The latter place gives two aisles, divided by perforated arches, with headways in the manner of groins, and at the east end an altar."

There can be no question now that although the original excavations were possibly enough Roman-British, the Papists' holes, as we have them now, are truly, as $\mathrm{Mr}$. Carter says, monastical.

How absurd old fashioned antiquaries were may be proved by the fact that the chimney that warmed the monks, and up which went the smoke from their kitchen, was pronounced to be a bustum, a flue employed for the cremation of the dead. As to the "Roman" column, that also is mediæval.

Curzon, in his "Monasteries of the Levant," 1849, says "the scenery of Meteora (Mt. Pindus in Albania) is of a very singular kind. The end of a range of rocky hills seems to have been broken off by some earthquake, or washed 242 


\section{ROCK MONASTERIES}

away by the Deluge, leaving only a series of twenty or thirty tall, thin, smooth, needle-like rocks, many hundred feet in height; some like gigantic tusks, some shaped like sugar-loaves, and some like vast stalagmites. These rocks are surrounded by a beautiful grassy plain, on three sides of which grow groups of detached trees, like those of an English park. Some of these rocks shoot up quite clean and perpendicularly from the smooth green grass, some are in clusters, some stand alone like obelisks. Nothing can be more strange and wonderful than this romantic region, which is unlike anything I have ever seen before or since. In Switzerland, Savoy, the Tyrol, is nothing at all to be compared to these extraordinary peaks. At the foot of many of these rocks there are numerous caves and holes, some of which appear to be natural, but most of them are artificial; for in the dark and wild ages of monastic fanaticism, whole flocks of hermits roosted in these pigeonholes. Some of these caves are so high up in the rocks that one wonders how the poor old gentlemen could ever get up to them, whilst others are below the surface, and the anchorites who burrowed in them, like rabbits, frequently afforded rare sport to parties of roving Saracens; indeed, hermit-hunting scenes seem to have been a fashionable amusement previous to the twelfth century. In early Greek frescoes and in small stiff pictures with gold backgrounds, we see many frightful representations of men on horseback in Roman armour, with long spears, who are torturing and slaying Christian devotees. In these pictures the monks and hermits are represented in gowns made of a kind of coarse matting, and they have long beards, and some of them are covered with hair ; these, I take it, were the ones most to be admired, as in the Greek Church sanctity is always in the inverse ratio to beauty. All Greek saints are painfully ugly, but the hermits are much uglier, dirtier, and older than the rest. They must have been very fusty 


\section{ROCK MONASTERIES}

people beside, eating roots and living in holes" like rats and mice."

On the summit of these needles of rock are monasteries. Of these there were twenty-four, but now seven alone remain tenanted by monks. The sole access to them is by nets let down by ropes and hauled up by a windlass, or as an alternative in the case of that of $\mathrm{S}$. Barlaam, by a succession of ladders.

As an example of a rock monastery and church in Egypt, I may quote the same author's description of that of Der el Adra, or of the Pully, situated on the top of Gebel el Ferr, where a precipice about 200 feet in height rises out of the waters of the Nile.

The access to it is by a cave or fissure in the rock, the opening being about the size of the inside of a capacious chimney. "The abbot crept in at a hole at the bottom, and telling me to observe where he placed his feet, he began to climb up the cleft with considerable agility. A few preliminary lessons from a chimney-sweep would have been of the greatest service to me, but in this branch of art my education had been neglected, and it was with no small difficulty that I climbed up after the abbot, whom I saw striding and sprawling in the attitude of a spread eagle above my head. My slippers soon fell off upon the head of a man under me. At least twenty men were scrambling and puffing underneath him. Arms and legs were stretched out in all manner of attitudes, the forms of the more distant climbers being lost in the gloom of the narrow cavern up which we were advancing. Thence the climb proceeded up a path. At the summit beside the monastic habitations was the church cut out of the rock, to which descent is made by a narrow flight of steps."

Mr. Curzon gives a plan of this church as half catacomb or cave, and one of the earliest Christian buildings which has preserved its originality. 


\section{ROCK MONASTERIES}

The caves of Inkermann in the Crimea have been already alluded to. Here is a description of a subterranean abandoned monastery and church.

"Having traversed a passage about fifty feet long, we reached a church, or rather the remains of one; for a portion of the living rock in which these works were cut had fallen and carried with it half of this curious crypt. Its semicircular vaulted roof, and the pillars in its corners, indicated it to be of Byzantine origin; while a Greek sculptured cross, in the centre of the roof, told that it was a temple dedicated to that religion. The altar, and any sculpture which might have existed near it, are gone, and have long since been burnt into lime, or built into some work at Sevastopol. Beyond the church we found a large square apartment, entered by another passage, and looking over the valley of Inkermann. A few more cells, resembling those on the stairs, composed the whole of this series of excavated chambers, the arrangements of which at once proclaimed them to have been a monastery. These were the cells, the refectory, and the church. There is nothing in their construction as a work of art; yet there is an absence of that roughness and simplicity which exist in many caverns of the opposite mountain, and which indicate their being of a much earlier date than these." 1

${ }^{1}$ Scott (C. H.), “The Baltic, the Black Sea, and the Crimea," Lond. 1854, p. 280. 


\section{CHAPTER X}

\section{CAVE ORACLES}

TANDING upon the pinnacle upon which is planted

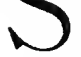
the marvellous Romanesque cathedral of Le Puy, and looking north, is seen in the distance the basaltic mass of Polignac crowned by a lofty donjon.

That mass of columnar basalt was occupied and held sacred in Roman times, and was dedicated to Apollo. In the courtyard of the castle is a well, l'Albime it is called, that descends to the depth of $\mathbf{2 6 0}$ feet, and there still exists an enormous stone mask of the solar god that closed it, and from the mouth of which oracles were given. How these were produced is now made clear. In the side of the well is a chamber cut out of the rock that concealed a confederate who uttered the response to the questioner, and the voice came up hollow and with reverberation betwixt the gaping lips of stone, to overawe and satisfy the inquirer.

"Before the old tribes of Hellas created temples to the divinities," says Porphyry in his treatise "On the Cave of the Nymphs,' "they consecrated caverns and grottoes to their service in the island of Crete to Zeus, in Arcadia to Artemis and Pan, in the isle of Naxos to Dionysos."

And from caves issued the most famous Grecian oracles, and the mysteries were often celebrated in them. 'The cave in which Zeus as an infant was concealed on Mount Ida naturally became sacred. Kronos had received the Kingdom of the World on condition that he should rear no male children. Accordingly when one was born he ate it. But when Zeus arrived, his mother gave Kronos a stone to eat 246 


\section{CAVE ORACLES}

in place of the child, and hurried off the babe to Crete, where it was nourished in a cave by the Corybantes, who sounded cymbals and drums to drown his cries.

There was a Charonion at Hierapolis, an account of which we get from Apulæus and Dio Cassius. It was deep. From the orifice, which was surrounded by a balustrade, escaped so dense a vapour that animals held in it died, and men who inhaled it were stupefied. The priests who ministered to the oracle professed to be immune, but Strabo tells us that they simply held their breath when they stooped over the fumes. He who desired to consult the oracle was for a while placed on a platform above the opening.

On the flank of Mount Citheron was a cave dedicated to the Nymphs. Those who desired to inquire of them entered the grotto, when it was supposed that the Nymphs inspired them with a knowledge of the future; and such persons were entitled Nympholeptes. The corresponding expression among the Latins was lymphatici, expressive of the pale and exhausted condition in which they were when they issued from the cave. Eusebius, Bishop of Cæsarea says: "There are exhalations that produce drowsiness and procure visions;" and Apulæus says: "Due to the religious fury they inspire, men remain without eating or drinking, and some become prophets and reveal future things."

Apollo was the god of prophecy above all others. He was born at Delos, according to the poets; and it is there that the Homeric poems say was one of his most ancient sanctuaries. Thence, doubtless, issued the twenty famous oracles at the epoch of the colonisation. At Delphi the priestess was seated on a tripod over a crack in the rock, from which exhaled mephitic vapours that rendered her delirious, and her incoherent exclamations were reduced into hexameters by the attendant priests. But there was also at Delos the Manteion, the prophetic grotto. This 


\section{CAVE ORACLES}

has of late year's been discovered along with the foundations of the temple. 'The Manteion is a gallery, naturally bored in the rock. The winds that penetrate it cause strange pipings and hollow moans, that served as an accompaniment to the oracles. But the most remarkable of these caverns was that of Trophonios in Beotia. Pausanius tells us the legend of its origin. The Beotians had suffered from drought for two years and sent to consult the oracle of Delphi. The reply received was that they must refer themselves to Trophonios at home. But who was the party? 'The Beotians had never heard of him. Then the oldest of their deputies recalled having once pursued a swarm of bees and followed it till it disappeared in a cave. That doubtless was the spot, and there, after the offering of sacrifices, 'Trophonios obligingly showed himself, and explained who he was and what were his powers. Since that time his oracle was much consulted, and happily an account of how he, or his priests, befooled visitors to the cave has been given us by Pausanius from his personal experience.

Those who wished to consult the oracle had first to purify themselves by spending some days in the sanctuary of the Guardian Spirit and of Fortune, to abstain from warm baths, but to bathe in the river Hercynia; they might eat as much as they liked of the meat offered in sacrifice. "You are conducted during the night to the river, where you are bathed and rubbed with oil by two boys of the age of thirteen. Then the priests take possession of you, and you are conducted to two fountains side by side. You drink of one, that of Oblivion, so as to disengage your thoughts from what is past, then that of Remembrance, to assure your recollecting what is about to take place. After having addressed your prayers to a statue, you go to the oracle, dressed in a linen tunic girded below the breast, and booted in the fashion of the country. 


\section{CAVE ORACLES}

The oracle is on the mountain above the sacred grove. It is surrounded by a marble wall, about the height of your waist. On this wall are planted twigs of copper linked together by copper filaments, and the gates are in this grating. Within this enclosure is a chasm, not natural, but excavated with a good deal of art and regularity, in form like a baker's oven. There is no ladder there for descent into the cave, and one is brought, that is light and narrow. Once at the bottom you see on one side, between the ground and the masonry, a hole about large enough for a man to squeeze through. One lies on the back, and holding in one hand a honey-cake, thrust the feet in at the opening, and then work oneself till the legs are in up to the knees. Then, all at once, the rest of the body is dragged down with force and rapidity, just as if you were swept forward by an eddy in a river.

"Once arrived in the secret place, all do not learn the future in the same manner. Some see what is to befall them unrolled in vision, others hear it by the ear. Then you ascend by the same opening whereby you descended, going feet foremost. No one, it is said, has died in the cave, with the exception of one of the guardsmen of Demetrius, and he went down, not to consult the god, but in hopes of plundering the sanctuary of its gold and silver; his carcase, they say, was not ejected by the orifice that is sacred, but was found in another spot. On issuing from the cave of Trophonios the priests lay hold of you, and after having planted you on the seat of Remembrance, question you as to what you have seen and heard. When you have told them, they hand you over, overwhelmed with fear, and unrecognisable by yourself and others, to other ministers who convey you to the edifice dedicated to the Good Genius and to Fortune."

'Those issuing from the cave for long after remained dejected, pale, and melancholy. Pausanius says that after a 


\section{CAVE ORACLES}

while one who had gone through the ordeal could laugh; but Suidas tells us that those who returned from having made the descent never smiled again, and this gave occasion to a saying relative to a preternaturally grave personage, "He has consulted the oracle of 'Trophonios."

Plutarch gives us some further particulars. The description made by one of the characters he introduces speaks of visions caught by inhaling a stupefying gas. Under its influence hallucinations were produced in which Trophonios himself was thought to appear, and the tortures of Tartarus were revealed. On emerging from the cave into fresh air, the questioner fell into fits of delirium, and thought he still saw strange visions. In the biography of Apollonios of Tyana, Philostratus tells us that the sage and wonder-worker was very desirous to penetrate into the cave, but that the priest raised objections and made difficulties, till at last his patience failed and he entered by main force and remained within seven days. So much in this semi-fictitious biography is true perhaps-that this hero did force his way in. It is also true that he had sufficient discretion not to tell what he had discovered of the tricks there perpetrated.

There was another of these caves at Acharaca, near Nysa, on the road to Tralles. The gas there exhaled had a medical healing virtue, and also gave occasion to the delivery of oracles. Persons suffering from an illness and placing confidence in the power of the gods, travelled thither and stayed some time with the priests, who lived near the care. 'Those ministers of the gods then entered the cavern and spent a night in it. After that they prescribed to their patients the remedies revealed to them in their dreams. Often, however, they took their patients along with them into the cave, where they were expected to remain for several days fasting and falling into prophetic sleep. 


\section{CAVE ORACLES}

About four centuries before the Christian era, there existed at Rome a temple dedicated to Jupiter Capitolinus, by the Tarquins, and beneath it was a subterranean chamber in which were preserved a collection of ancient oracles, the keeping of which was confided to his officers, the duumviri, and the penalty of death attached to the divulgation unlicensed, of their contents.

According to the legend, a strange woman, the sibyl of Cumæ, brought to Tarquin the old nine books of oracles, and demanded for them three hundred pieces of gold. The king considered the price exorbitant, scoffed at the woman, and refused to buy. Thereupon the sibyl cast three of the volumes into the fire, and demanded the same sum precisely for the remaining six. Tarquin again declined to purchase. She then burnt three more, but still required for the remainder the original price. The king now thought that he had acted unwisely, and hastened to conclude the bargain and secure the oracles that contained prophecies relative to the destiny of the Roman people.

The oracles were written on palm-leaves in Greek, and with various signs and hieroglyphs, and the volumes were bundles of these leaves tied together.

In the year 671 of Rome, eighteen years before the Christian era, the old Temple of Jupiter, built by the Tarquins, was destroyed by fire, and with it perished the Books of Destiny. Six years after the temple was rebuilt, and an attempt was made to recover the Sibylline oracles, by sending throughout Italy for oracles reported to be Sibylline. The deputies sent brought back from Erythæa a thousand verses, but the collection rapidly increased in such quantities that Augustus ordered them to be examined, and such as proved to be worthless he burnt. After a second sifting, those that remained were put into two golden coffers and placed under the pedestal of the statue of the Palatine Apollo. 


\section{CAVE ORACLES}

As is well known, there were in circulation a number of forged Sibylline oracles; some of these were the product of the Jewish Therapeutæ, others of Christians. In his hatred of Christianity, the Emperor Julian ordered search to be made for these fictitious oracular books, that they might be destroyed. In 363 the Temple of the Palatine Apollo caught fire and was destroyed. The Christians charged Julian with having caused the fire so as to get rid of the Sibylline oracles hid under the statue of Apollo. But these had not been injured; the gold boxes in which they were, were opened, and to their confusion the Christians found that the oracles contained no prophecies concerning Christ, only sortes celebrating the gods Zeus, Aphrodite, Hera, \&c.

The accusation brought by the Christians against Julian recoiled upon them, for it was they who, later, by the hands of Stilicho, destroyed the collection. The order for the destruction was given by two Christian emperors, Honorius and Arcadius, on the plea that these oracles favoured and encouraged paganism.

Saul, it will be remembered went to consult a witch in the cave of Endor, where she conjured up before him the spirit of Samuel.

Isaiah rebukes the Jews for "lodging in the monuments," doubtless to obtain oracles from the dead, to raise up the ghosts of the deceased, and exhort from them prophecies as to the future. As already pointed out, the dead and the pagan gods were one and the same. To consult a deity was to consult a hero or an ancestor of a former age.

There is a curious story in an Icelandic Saga of a shepherd, named Hallbjörn, on a farm where was a huge cairn over the dead scald or poet Thorleif. 'The shepherd, whilst engaged on his guard over his master's flock, was wont to lie on the ground and sleep there. On one occasion he saw the cairn open and the dead man come forth, and Thorleif promised to endow him with the gift of 252 


\section{CAVE ORACLES}

poetry if he would compose his first lay in his, the dead man's praise. And he further promised that Hallbjörn should become a famous scald and sing the praises of great chieftains. Thereupon the tenant of the tomb retired within again, and the shepherd on waking found himself endowed with poetic gift, and he sang a lay in honour of Thorleif. "And he became a famous scald, and went abroad, and sang songs in honour of many great men, and obtained high honour, and good gifts, and became very wealthy." 1

It will be remembered that Saul's interview was with the ghostly Samuel through the intervention of the witch. And there are many stories of living men endeavouring to obtain knowledge of the future through invocation of the spirits of the dead. Indeed spiritualists at the present day carry on the same business.

One thing that conduced to the belief that certain caves were inhabited by gods and spirits, was that strange sounds at times issued from them. These were caused by currents of air entering some of the apertures and vibrating through the passages, provoking notes as if these galleries were organ pipes. This is the explanation of the Eolian cavern of Terni, supposed to be the abode of spirits; and a cave near Eisenach was long reported to be an entrance to hell, because of the moans and sighs that were heard issuing from it.

The echo also was quite inexplicable to the ignorant, and was assumed to be the voice of some spirit or mountain gnome living in the heart of the rock, to whose habitation a cave gave access.

An abandoned mine with a pool at the bottom, on Dartmoor, is thought to be the abode of a spirit whose wails may be heard when the wind blows, and whence a voice issues calling out the name of that person who is next doomed to die in the parish of Walkhampton.

The most remarkable representative in the Middle Ages

1 Fornmanna Sögur, Copenh. 1827, iii. pp. 102-3. 


\section{CAVE ORACLES}

of the cave of Trophonios was that in Lough Derg in Ireland, the purgatory of S. Patrick as it was called. The origin is obscure, but it sprang into notoriety through the publication by a monk, Henry of Saltrey, of the descent of a knight Owain into it. Owain had been in the service of King Stephen, and he made his descent in the year 1153. Whether there ever were such a person as the knight Owain, or whether he was a mere invention of Henry of Saltrey is uncertain. Saltrey's account is precise as to the various stages through which Owain passed, and it is a vulgar rendering of the common stories of visits to purgatory, of which Dante's is the highest and most poetical version.

Lough Derg is among the dreary and barren mountains and moorlands in the south of the County of Donegal; in it is an island, with ribbed and curiously shaped rocks, and among these was supposed to be the entrance to purgatory.

Giraldus Cambrensis, who wrote his "Topography of Ireland" in 1187, mentions the island in Lough Derg as among the wonders of Ireland. ${ }^{1}$ It was, he says, divided into two parts, of which one was fair and pleasant, while the other part was wild and rough, and believed to be inhabited only by demons. In this part of the island, he adds, there were nine pits, in any one of which, if a person was bold enough to pass the night, he would be so much tormented by the demons that it was a chance if he were found alive in the morning; and it was reported that he who escaped alive would, from the anguish he suffered there, be relieved from the torments of the other world. Giraldus continues by telling us that the natives called the place Patrick's purgatory, and that it was said that the saint had obtained from God this public manifestation of the punishments and rewards of the other world, in order to convince his incredulous hearers.

1 But there is no mention of it among the wonders of Ireland in the Irish Nennius. 


\section{CAVE ORACLES}

Numerous visitors to Lough Derg in the Middle Ages published the narrative of what they had there seen and undergone, and rivalled each other in the extravagance of their accounts. There was a monastery on Lough Derg, and the monks had the key to the entrance to the carern, but no visitor was suffered to pass within without the consent of the bishop of the diocese, and the payment of a heary fee. Among all the extravagance that was written by visitors about the purgatory, some retained their common sense, and perceived that there was either fraud or hallucination in the visions there supposed to be seen.

Froissart gives an account of a conversation he had with Sir William Lisle on this subject: "On the Friday in the morning we rode out together, and on the road I asked him if he had accompanied the King in his expedition to Ireland. He said he had. I then asked him if there was any foundation of truth in what was said of S. Patrick's Hole. $\mathrm{He}$ replied that there was, and that he and another knight had been there. They entered it at sunset, remained there the whole night, and came out at sunrise the next morning. I requested him to tell me whether he saw all the marrellous things that are said to be seen there. He made me the following answer: "When I and my companion had passed the entrance of the cave, called the purgatory of S. Patrick, we descended three or four steps (for you go down into it as into a cellar), but found our heads so much affected by the heat that we seated ourselves on the steps, which are of stone, and such a drowsiness came on that we slept there the whole night.' I asked if, when asleep, they knew where they were, and what visions they had. He replied that they had many and strange dreams, and they seemed, as they imagined, to see more than they would hare done had they been in their beds. This they were both assured of. "When morning came and we were awake, the door of the cave was opened, and we came out, but instantly lost all recollection of 255 


\section{CAVE ORACLES}

everything we had seen, and looked on the whole as a phantasm." "

It is apparent from this that the wild descriptions given by others were merely an account of their dreams or hallucinations; in many cases purely imaginary accounts, given for the sake of creating a sensation. I do not suppose that the monks of Lough Derg devised any scenic effects, but left the imagination of the dupes to riot of its own accord unassisted. In the fifteenth century a monk of Eymstadt, in Holland, undertook the pilgrimage to Lough Derg. He arrived at the lake, and applied to the prior for admission, who referred him to the bishop of the diocese. The monk then repaired to him, but as he was "poor and moneyless," the servants refused to admit him into their master's presence. Having, however, with difficulty obtained an audience, he begged humbly to be suffered to visit S. Patrick's purgatory. 'The Bishop of Clogher demanded a certain sum of money, which, he said, was due to him from every pilgrim who came on this errand. The monk represented his poverty, and after much urgent solicitation, the bishop grudgingly gave him the necessary licence. He then went to the prior, performed the usual ceremonies, and was shut up in the cavern. There he remained all night, in constant expectation of seeing something dreadful; but when the prior let him out next morning he had to admit that he had seen no vision of any sort. 'Thoroughly dissatisfied with his experiences, he went direct to Rome, and reported what he thought of S. Patrick's purgatory to Pope Alexander VI. The Pope was convinced that the whole thing was a fraud, and ordered the destruction of the purgatory. It was the eve of the Reformation; mistrust of miracles was rife, and the Pope was anxious to suppress one that when investigated might prove a scandal.

The purgatory was accordingly suppressed, the cave 256 


\section{CAVE ORACIES}

closed, but not destroyed, and no pilgrims admitted to it; this was in 149\%. The closing of the cave did not, however, interfere with the pilgrimage, and the Archbishop of Armagh in 1503 urged on Pope Pius III. to withdraw the prohibition. This was done, and profuse indulgences were offered to such as revisited the cave or at all events took part in the Lough Derg pilgrimage. On 12th September 1632, Sir James Balfour and Sir William Stewart, carrying out the orders of the Government, seized "for her Majesty's use and benefit the Island of the Purgatory," and unroofed and otherwise destroyed the monastic buildings there. But superstition is not to be killed by Acts of Parliament. By a statute of the second year of Queen Anne all pilgrimages to S. Patrick's purgatory were decreed to be "riotous and unlawful assemblies," and were made punishable as such; and resort to the purgatory had become more frequent owing to Clement $\mathbf{X}$. having granted a Plenary Indulgence to such as visited it. Since then these Indulgences have been repeatedly renewed. At present the pilgrimages are again in full swing, and there is a prior on the island, a hospice for the reception of the visitors, and a chapel of S. Patrick and another of S. Mary. "Between the two churches the space is taken up with the Campanile and Penitential beds. There are five of these beds, and they are dedicated to SS. Dabeoc, Columba, Catherine, Brendan, and Bridget. They are circular in form, measuring, with the exception of S. Columba's, about ten feet in diameter. S. Columba's is about twice the size of the others. 'They are surrounded with walls, varying in height from one to two feet and each of them is entered by a narrow gap or doorway." 1

It would seem then that the old superstitious practices are being reverted to as nearly as the spirit of the times will allow, and the destruction of the!cave itself will admit.

1 "Lough Derg," by Rev. J. E. McKenna, Dublin, n.d. 


\section{CAVE ORACLES}

It is perhaps needless to sadd that there is no historical evidence for the apostle of Ireland having ever been at Lough Derg. Derg is probably a mistake for Deirg, and Lough Deirg would mean the Lake of the Cave. Gough, in his additions to Camden, thus described the purgatory: "It was about sixteen feet and a half long, by two feet one inch wide, built of freestone, covered with broad flags and green turf laid over them, and was so low and narrow that a tall man could hardly sit, much less stand in it. In the side was a window just wide enough to admit a faint ray of light; in the floor a cavity capable of containing a man at his length, and under a large stone at the end of the pavement a deep pit; the bottom of the cave was originally much below the surface of the ground. It stood on the east side of the church, in the churchyard, encompassed with a wall, and surrounded by circles or cells, called the beds, scarcely three feet high, denominated from several saints. The penitents who visited the island, after fasting on bread and water for nine days and making processions round these holy stations thrice a day barefoot, for the first seven days, and six times on the eighth, washing their weary limbs each night in the lake, on the ninth enter the cave. Here they observe a twenty-four hours fast, tasting only a little water, and upon quitting it bathe in the lake, and so conclude the ceremony.

"Leave being first obtained of the bishop, the prior represented to the penitents all the horror and difficulty of the undertaking, suggesting to them at the same time an easier penance. If they persevered in their resolution, they were conducted to the door with a procession from the convent, and after twenty-four hours confinement let out next morning with the like ceremony." 1

1 "St. Patrick's Purgatory," by Thomas Wright, London, 1844. A nalecta Bollandiana,'t. xxvii. (1908). O'Connor, "St. Patrick's Purgatory," Dublin, 1895. MacRitchie, "A Note on St. Patrick's Purgatory," in the Journal of the Roy. Soc. of Ant. of Ireland, 1901.

258 


\section{CAVE ORACLES}

As may well be supposed, after the long preliminaries and the heavy fees paid, the penitents could hardly, unless unusually strong-minded like the Dutch monk, declare roundly that they had seen nothing. I do not suppose, as already said, that there was any fraud deliberately enacted, personages dressing up as devils and angels, but that the visitor's own dreams, and his vanity or lively imagination were left to propagate the story of the marvels to be seen and heard in Lough Derg.

But wonderful caves, entrances to a mysterious underworld, are common in all countries. A story is told of Friar Conrad, the Confessor of S. Elizabeth of Thuringia, a barbarous, brutal man, who was sent into Germany by Gregory IX. to burn and butcher heretics. The Pope called him his "dilectus filius." In 1231 he was engaged in controversy with a heretical teacher, who, beaten in argument, according to Conrad's account, offered to show him Christ and the Blessed Virgin, who with their own mouths would ratify the doctrine taught by the heretic. To this Conrad submitted, and was led into a cave in the mountains. After a long descent they entered a hall brilliantly illumined, in which sat a King on a golden throne and by him the Queen Mother. The heretic prostrated himself in adoration, and bade Conrad do the same. But the latter drew forth a consecrated host and adjured the vision, whereupon all vanished.

The German stories of the mountain of Venus, in which the Tannhäuser remains, or of Frederick Barbarossa, in the Unterberg, or the Welsh stories of King Arthur in the heart of the mountain, seen occasionally, or the Danish fables of Holger Dansk in the vaults under the Kronnenburg, all refer to the generally spread belief in an underworld inhabited by spirits.

In the year 1529 died Lazarus Aigner of Bergheim, near Salzburg, a poor man. At his death he handed over to his 259 


\section{CAVE ORACLES}

son a MS. account of a descent he had made into the underworld in 1484, and this was at once published and created a considerable sensation.

According to his account, in the year just mentioned, he was on the Unterberg with his master, the parish priest, Elbenberger, and another, when they visited a chapel on the rock, above the entrance to which were cut the letters S.O.R.G.E.I.S.A.T.O.M., out of which they could make nothing.

On returning home the priest observed that he wished that Lazarus would revisit the place, and make sure that the inscription had been accurately copied. Accordingly, next day, Aigner reascended the mountain and found the chapel again. But he had started late, having his ordinary work to do before he had leisure to go, and the evening was darkening in. As the way led by precipices, he deemed it inadvisable to retrace his steps that night, and so laid himself down to sleep. Next morning, 'Thursday, he woke refreshed, but to his amazement saw standing before him an aged barefooted friar, who asked him whence he came and what had brought him there. To this Lazarus Aigner answered truthfully. Then the hermit said to him, "I will explain to you what is the siguification of these letters, and will show you something in vision."

Then the barefooted friar led him into a chasm, and unlocked an iron door in the rock, by means of which Lazarus was admitted into the heart of the mountain. There he saw a huge hall out of which went seven passages that led to the cathedral of Salzburg, the church of Reichenhall, Feldkirch in Tirol, Gemund, Seekirchen, S. Maximilien, S. Michael, Hall, St. Zeno, Traunstein, S. Dionysius and S. Bartholmæ on the Konigsee. Here also Aigner saw divine worship conducted by dead monks and canons, and with the attendance of countless dead of all times in strange old-world costumes. He recognised many whom he had known when 260 


\section{CAVE ORACLES}

alive. Then he was shown the library, and given the interpretation of the mysterious letters, but as it was in Latin, Aigner forgot it. After seven days and as many nights spent in the underground world, he returned to daylight, and as the hermit parted with him he solemnly bade him reserve the publication of what he had seen and heard till the expiration of thirty-five years, when times of distress and searchings of heart would come, and then the account of his vision might be of profit. And exactly at the end of the thirty-five years Lazarus Aigner died. There can be little doubt that, if the whole was not a clumsy fabrication, it was the record of a dream he had when sleeping on the mountain outside the chapel of the Unterberg.

Roderic, the last of the Goths, has been laid hold of by legend and by poetry. Southey wrote his poem on the theme, and Scott his "Vision of Don Roderic," an odd blunder in the title, as don was not used prior to the ninth century. Roderic ascended the throne of the Goths in Spain in 709. According to the legend he seduced the daughter of Julian, Count of the Gothic possessions in Africa. She complained to her father, and he in revenge invited the Moors, whom he had hitherto valiantly opposed, to aid him in casting Roderic from his throne, the issue of which was the defeat and death of Roderic, and the occupation of nearly the whole peninsula by the Moors. At Toledo is a cave with a tower at its entrance formerly dedicated to Hercules, and tradition said that he who entered would learn the future fate of Spain. The cave still exists. The entrance lies near San Ginos; it was opened in 1546 by Archbishop Siliceo, but has never since, according to Forbes, been properly investigated. The story went that in spite of the entreaties of the prelate and some of his great men, Roderic burst open the iron door, and descended into the cave, where he found a bronze 261 


\section{CAVE ORACLES}

statue with a battle-axe in its hands. With this it struck the floor repeatedly, making the hall reverberate with the sound of the blows. Then Roderic read on the wall the inscription, "Unfortunate king, thou hast entered here in evil hour." On the right side of the wall were the words, "By strange nations thou shalt be dispossessed and thy subjects departed." On the shoulders of the statue were written the words, "I summon the Arabs," and on its breast, "I do mine office." The king left the cave sorrowful, and the same night an earthquake wrecked the tower and buried the entrance to the cave.

Evidently Shakespeare had this story in his mind when he wrote the scene of the descent of Macbeth into the cave of Hekate.

Although the oracles had ceased to speak in the pagan temples and caves, yet the desire remained to question the spirits and to inquire into the future, and for this purpose throughout the Middle Ages either wizards were had recourse to that a look might be taken in their magic mirrors, or else the churches were resorted to and the sacred text received as the response of God to some question put by the inquirer. When Chramm revolted against his father Clothair, he approached Dijon, when, says Gregory of Tours, the priests of the cathedral having placed three books on the altar, to wit the Prophets, the Acts of the Apostles, and the Gospels, they prayed God to announce to them what would befall Chramm, and by His power reveal whether he would be successful and come to the throne, and they received the reply as each opened the book.

Gregory also says that Meroveus, flying before the wrath of his father Chilperic, placed three books on the tomb of S. Martin at Tours, the Psalter, the Book of Kings, and the Gospels; he kept vigil all night, and passed three days fasting. But when he opened the books at random, 262 


\section{CAVE ORACLES}

the responses were so alarming that he despaired, and left the sepulchre in tears. ${ }^{\text {? }}$

The councils sought to put an end to this superstition. The sixteenth canon of the Council of Vannes, held in 465, forbade clerks, under pain of excommunication, to consult these sortes sacre, as they were called. This prohibition was extended to the laity by the Council of Agde in 506, and by that of Orleans in 511. It was renewed repeatedly, as, for instance, in the Council of Auxerre in 595, by a capitulary of Charlemagne in 789, and by the Council of Selingstadt in 1022, but always in vain. If inquirers might not seek for answers in the churches, at the tombs of the Saints, they would seek them in the dens of necromancers. In spite of this condemnation, consultation of the divine oracles even formed a portion of the liturgy; and at the consecration of a bishop, at the moment when the Book of the Gospels was placed on his head, the volume was opened, and the first verse at the head of the page was regarded as a prognostication of the character of his episcopate. 'There are numerous accounts of such presages in the chronicles. Guibert of Nogent relates, for instance, that when Landric, elected Bishop of Noyon, was receiving episcopal unction, the text of the Gospel foreshadowed evil_- "A sword shall pierce through thine own soul also." After having committed several crimes, he was assassinated. He had, as his successor, the Dean of Orleans; "the new bishop on being presented for consecration, there was sought, in the Gospel, for a prognostication concerning him, but the page proved a blank. It was as though God had said, "With regard to this man I have nothing to say." And in fact he died a few months later.

The same usage was practised in the Greek Church. At the consecration of Athanasius, nominated to the patriarchate

1 For many more instances see Lalanne (L.), Curiosités des Tradilions, Paris, 1817. 


\section{CAVE ORACLES}

of Constantinople by Constantine Porphyrogenetos, "Caracalla, Bishop of Nicomedia, having brought forward the Gospel," says the Byzantine historian Pachymeros, "the people were alert to learn the oracle of the opening of the volume. The Bishop of Nicomedia having perceived that the leading words were 'prepared for the devil and his angels,' groaned in his heart, and covering the passage with his hand, turned the leaves and opened at these words, 'and the birds of the air lodged in the branches of it,' which seemed to have no connection with the ceremony. All that could be was done to conceal the oracles, but it was found impossible to cover up the fact. It was said that these passages condemned the consecration, but they were not the effect of chance, because there is no such thing as chance in the celebration of the divine mysteries." When Clovis was about to attack the Visigoths and drive them out of Aquitaine, he sent to inquire of the oracles of God at the tomb of S. Martin. His envoys arrived bearing rich presents, and on entering the church they heard the chanter recite the words of the psalm, "Thou hast girded me with strength unto the battle: 'Thou shalt throw down mine enemies under me. Thou hast made mine enemies also to turn their backs upon me: and I shall destroy them that hate me" (Ps. xviii. 39, 40). They returned with joy to the king, and the event justified the oracle.

I might fill pages with illustrations, but as these have no immediate reference to cave oracles, I will quote no more. It is obvious that recourse to churches and the tombs of the saints had taken the place of inquiries at the temples of the gods, and the grottoes dedicated to Fawns and Nymphs. So also it was by no means uncommon for recourse to be had to churches in which to sleep so as to obtain an oracle as to healing, as it had been customary for the same purpose to seek pagan temples. 'This was called Incubation. 


\section{CAVE ORACLES}

The dreams produced were often the result of inhaling a gas that escaped in some of the caves, or through fissures in the floors of the temples. At Hierapolis in Phrygia was a cavern of Cybele. At the close of the fifth century, when the temple of the goddess had been completely abandoned through the interdiction of paganism, the philosopher Damascius, who had remained faithful to the old beliefs of his country, descended, along with a companion, into the Charonion in spite of the danger attending it, or was supposed to exist. He came forth safe and sound, according to his own account, but hardly had he reached his home before he dreamt that he had become Attys, the lover of Cybele, and that he assisted at a festival held in his honour. There were other such caves. In the visions seen by those sleeping in them, the divinities of healing appeared and prescribed the remedies to be taken by those who consulted them. Pilgrimages to these resorts-temples and caves of Esculapius, Isis, and Serapis, were common events. 'Those who desired to consult Serapis slept in his temple at Canope. When Alexander was sick of the malady whereof he died, his friends went thither to learn if any cure were possible. "Those who go to inquire in dream of the goddess Isis," says Diodorus Siculus, "recover their health beyond expectation. Many have been healed of whom the physicians despaired." The temples were hung with exvotos. At Lebedes, in Lydia, the sick went to pass the night in the temple of the Soteri, who appeared to them in dreams. It was the same in a temple in Sardinia. So also in one of Ino in Laconia. In the Cheronese, the goddess Henithæa worked the same miracles as did Isis. She appeared in dream to the infirm and prescribed the manner in which they might be healed. In the Charonion of Nyssa it was the priest who consulted the gods in dream. In the temple of Esculapius near Citheræa, a bed was always ready for incubation. Christianity could 265 


\section{CAVE ORACLES}

not uproot so deeply founded superstitious convictions and practices.

The Emperor Constantine consecrated to the archangel Michael two churches near Byzantium, one was at Anaplous, on the Bosphorus, the other on the opposite shore at Brochoi. This second church replaced a temple that had, according to tradition, been founded by the Argonauts, and was called the Sosthenion. According to John Malala, Constantine slept in the temple and asked that he might be instructed in dream to whom the church which was to replace it should be dedicated. Great numbers from $\mathbf{B y}$ zantium and the country round had resort to these churches to seek the guidance of the archangel in their difficulties and a cure when sick. Sozomen, the ecclesiastical historian, relates an instance of a cure effected in one of the churches of S. Michael. Aquilinus, a celebrated lawyer, was ill with jaundice. "Being half dead, he ordered his servants to carry him to the church, in hopes of being cured there or dying there. When in it, God appeared to him in the night and bade him drink a mixture of honey, wine and pepper. He was cured, although the doctors thought the potion too hot for a malady of the bile. I heard also that Probian, physician of the Court, was also cured at the Michaelon by an extraordinary vision, of pains he endured in his feet." "Not being able to record all the miracles in this church, I have selected only these two out of many." 1

That which took place at the Michaelons on the Bosphorus occurred elsewhere, in churches dedicated to SS. Cosmas and Damian. At Egæ in Cilicia was a shrine of Asculapius, and incubation was practised in his temple. It afterwards became a church of Cosmas and Damian, and the same practices continued after the rededication. The chain of

1 Hist. Eccles., ii. 3 ; see for many illustrations Maury (A.), La Magie, Paris, 1860. Part II., chap. i. 


\section{CAVE ORACLES}

superstitious practices continued after the change in religion without any alteration. In the church of $\mathrm{S}$. Hilaire in France is to be seen the saint's bed, "to which they carry insane persons, and after certain prayers and religious rites, they lay them to sleep in the bed, and they recover." 1

In my "Book of South Wales" I have shown that the same usage continued as late as the beginning of the nineteenth century in the church of Christchurch near Caerleon, on the gravestone of one John Colmer, and have reproduced a print of 1805 , representing a man lying there to get cured.

We have accordingly a series of customs beginning in caves dedicated to heathen deities, transferred to their temples, then to churches under the invocation of Christian saints and of angels.

One might well have supposed that with the advance of education, there would have been an end to all cave oracles and grotto apparitions. But not so-there is a special mystery in a cave that stimulates the imagination, and the final phase of this tendency is the apparition at Lourdes, and the consecration of the grotto. The vision at Le Salette has not retained its hold on the superstitious, because it was on an alp, but that of Lourdes being in a cave, roused religious enthusiasm to the highest pitch. That the supposed apparition talked nonsense made the whole the more delightfully mysterious.

"Yonder, beneath the ivy which drapes the rock, the grotto opens," writes Zola, "with its eternally flaming candles. From a distance it looks rather squat and misshapen, a very narrow and humble aperture for the breath of the Infinite which issued from it. The statue of the Virgin has become a mere speck, which seems to move in the quiver of the atmosphere heated by the little yellow flames. To see anything it is necessary to raise oneself;

1 Jorlocus Sincerus, Iin. Galline, $161 \%$. 


\section{CAVE ORACLES}

for the silver altar, the harmonium, the heaps of bouquets thrown there, the votive offerings streaking the smoky walls, are scarcely distinguishable from behind the railing."

The floor of the grotto is scarcely raised above the level of the river Gave, which has had to be thrust back to make room for a passage to the mouth of the cavern. The whole story of the apparition of the Virgin there rests on the unsupported assertion of an hysterical scrofulous peasant girl. But who can say that the cult of sacred grottoes is a thing of the past when tens of thousands of pilgrims visit Lourdes annually, and believe in the story that confers sanctity on it! 


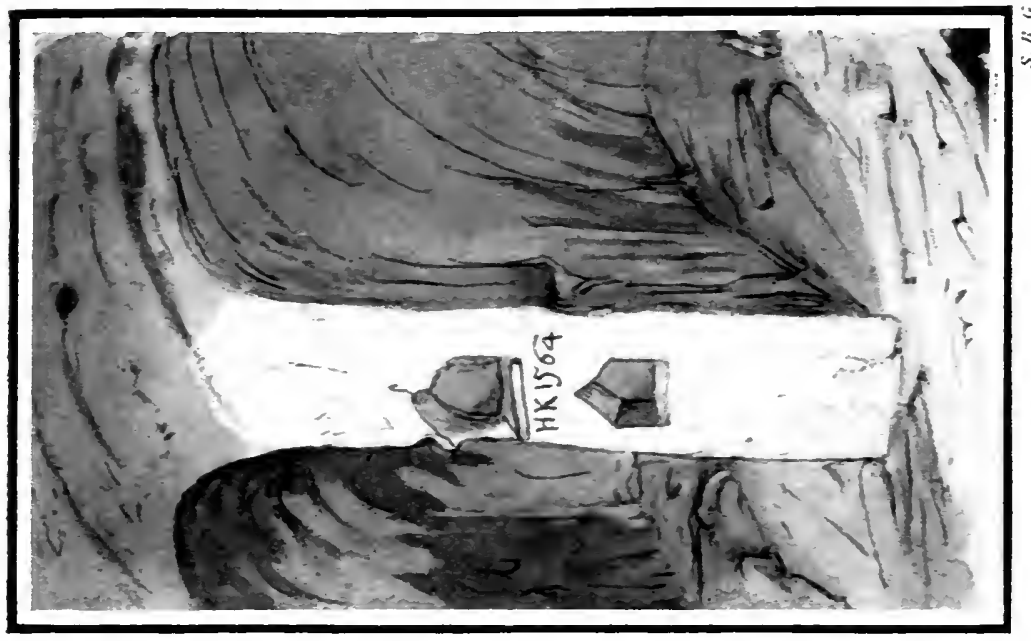

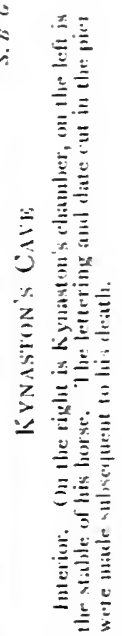

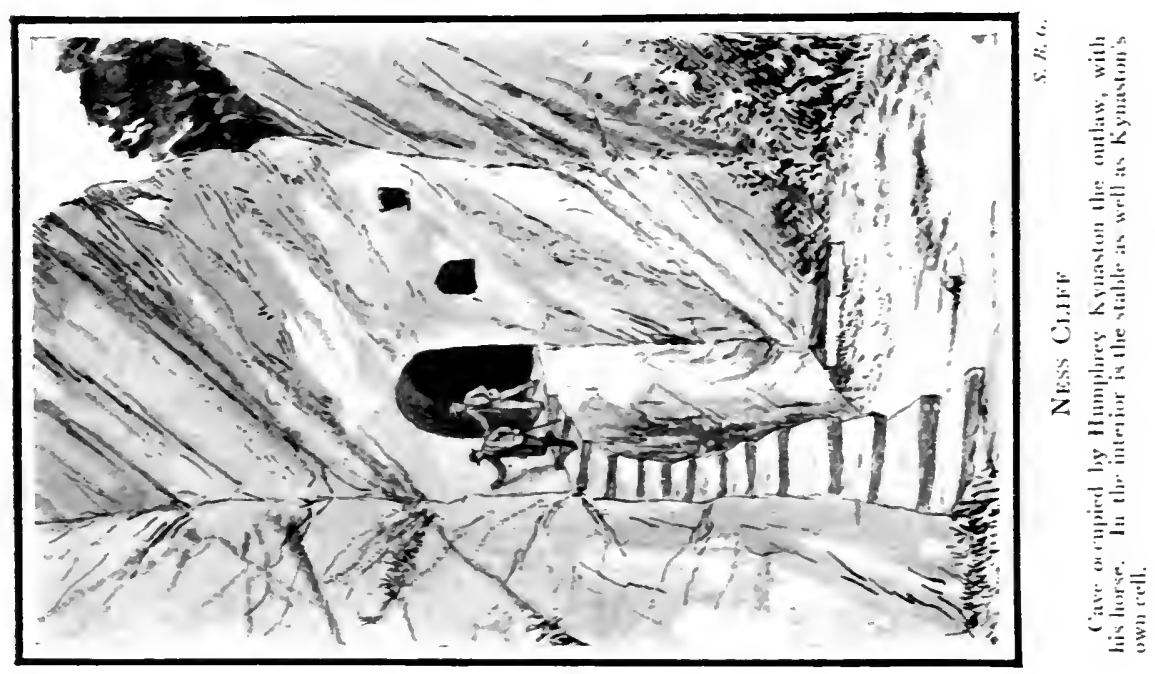





\section{CHAP'TER XI}

\section{ROBBERS' DENS}

THE name of the outlaw, Humphrey Kynaston, who, with his horse, lived in the face of a precipice, is not likely speedily to be forgotten in Shropshire; his exploits are still matter of tradition, and the scenes of his adventures are yet pointed out.

Humphrey was the son of Sir Roger Kynaston, of Hordley, near Ellesmere. The family derived from Wales and from the princes of Powys. Their arms were argent, a lion rampant sable.

Sir Roger Kynaston had zealously embraced the side of the York faction. King Henry VI. had attempted to make peace by holding a conference in London, when the Lord Mayor at the head of fire thousand armed citizens kept peace between the rival parties. Henry proposed an agreement, which was accepted, and then the King, with representatives of both sides, went in solemn procession to S. Paul's. To the great joy of the spectators, the Yorkist and Lancastrian leaders walked before him arm in arm, Richard, Duke of York, leading by the hand the queen, the real head of her husband's party.

But the pacification had been superficial. The Yorkists were determined to win the crown from the feeble head of Henry. At their head was the Earl of Warwick, and the King had hoped to get him out of the way by making him Governor of Calais. But strife broke out again six months after the apparent reconciliation at S. Paul's. The Earl of Salisbury was the first to move; but he had no sooner put 269 


\section{ROBBERS' DENS}

himself in march from Yorkshire to join the Duke of York at Ludlow, than Lord Audley, with 7000 men, attempted to intercept him. They met at Blore Heath, in Staffordshire. Audley was drawn into a snare, and slain by Sir Roger Kynaston with his own hand; along with him fell 2000 of his followers. 'Ihenceforth the Kynastons assumed, not only the Audley arms and the motto, "Blore Heath," but the rising sun of York as their crest.

Wild Humphrey was the son of Sir Roger Kynaston, by his wife the Lady Elizabeth, daughter of Henry Gray, Earl of 'Tankerville, and Lord of Powys. He was the second son, and not expecting to succeed to the family estates, was given the constableship of the castle of Middle, which had at one time belonged to the Lords le Strange, but which had lapsed to the Crown.

He sadly neglected his duties, and allowed the castle to fall into disrepair, almost into ruin. This was not altogether his own fault. 'The castle was of importance as guarding the marches against the Welsh, always ready, at the least provocation, to make raids into England. The office of constable was honorary rather than remunerative, a poor recompense for the services rendered by Sir Roger to the Yorkist cause. Humphrey was expected to keep up the castle out of his own resources, and he was without private means. It was true that with the accession of the House of Tudor, danger from the Welsh was less inminent: but Henry VII. was a parsimonious monarch, careful mainly to recover for the exchequer the sums of which it had been depleted in the Wars of the Roses.

As Humphrey was short of money, he took to robbery. 'The Wars of the Roses had produced anarchy in the land, and every man's hand was against his fellow, if that fellow had something of which he might be despoiled.

The story is told that one day Wild Humphrey rode to the manor-house of the Lloyds of Aston, and requested a 270 


\section{ROBBERS' DENS}

draught of wine. With ready hospitality a silver beaker was brought forth swimming with the juice of the grape. Humphrey, who was mounted, drained it to the last drop, then, striking spurs into his horse, galloped away, carrying the silver vessel with him. As has been said of Robin Hood, so it was told of the Shropshire freebooter, that he robbed the rich and befriended the poor. On one occasion he stopped the steward of a gentleman and plundered him of the rents just received. The Lord of the Manor sent him a message that he had been a forbearing landlord, but now he absolutely must put the screw upon his tenants to make up for his loss. Kynaston at once waylaid another gentleman's steward, and paid the first back to the last penny with the proceeds of the second robbery.

His depredations at length became so intolerable that he was outlawed in the eighth year of Henry VII. As this year began on the 22nd August 1490, and did not end till the 21st of August 1491, it is not quite certain in which year of our reckoning he was placed under ban.

He was now obliged to fly from the dilapidated castle of Middle, and seek himself out a place of refuge. This he found or made for himself in the face of the cliff of Ness.

This is a hill of new red sandstone, near Bass Church, that forms an abrupt scarp towards the south. The top commands a superb view of the Shropshire plain, with the Breiden Hills rising out of them, and the Long Mynd to the south. The western horizon is walled up by the Welsh mountains. Formerly the head and slopes of Ness Cliff were open down, but have been enclosed and planted of late years by Earl Brownlow, so that it is not easy to realise what the appearance was when Wild Humphrey took up his abode in the rock.

In the cliff, that is reached by a rapid ascent, and which rises above the slope some $\tau 0$ feet, he cut a flight of steps in the side of a buttress that projects, till he reached the 271 


\section{ROBBERS' DENS}

main face of the crag, about half-way up. Then he scooped out a doorway, next excavated two chambers, one to serve as a stable for his horse, the other for a habitation for himself. In the latter he formed a hearth, and bored a hole upwards in a slanting direction, till he reached daylight, and this served as chimney. Beside his door he cut a circular orifice to act as window. The doorway was closed by a stout door sustained in place by a massive bar, the socket holes to receive which remain.

In the pier between the stable and his own apartment, he cut two recesses, probably to receive a lamp. Between these a later hand has engraved the initials H.K., and the date 1564. As Humphrey died in 1534, this was, of course, none of his doing.

At the foot of the cliff near the first step is a trough or manger cut in the living rock, apparently to receive water, but as no water exudes from the rock, it must have served for the oats or other corn given to his horse. It is traditionally said that Wild Humphrey's horse pastured in proximity to the Ness. When Humphrey saw danger, and when the shades of evening fell, he whistled; whereupon the beast ran like a cat up the narrow steps in the face of the rock, and entered its stable. Once there, Kynaston was master of the situation, for only one man at a time could mount the stair, and this was commanded by his window, through which with a pike he could transfix or throw down an intruder.

Where now stands the National School at the foot of the hill was at that time a meadow, to the grass of which his horse was partial.

The farmer to whom the meadow belonged naturally enough objected, and collected a number of men who linked themselves together with ropes and surrounded the field. The horse took no notice but continued browsing. The ring gradually contracted on him. Kynaston saw the pro272 


\section{ROBBERS' DENS}

ceeding from his eyrie, and uttered a shrill whistle. At once the gallant steed pricked up his ear's, snorted, ran, leaped clean over the head of a man, and scrambled up the stair in the cliff, to his master's shelter. On another occasion a thief, thinking it no harm to rob a felon, succeeded in leaping on the horse's back. But the beast, feeling that some one was astride of him other than Wild Humphrey, ran to the cliff, and the rider, frightened at the prospect of being carried up the rock side and into the power of the desperate outlaw, was but too thankful to throw himself off and get away with a broken arm.

Humphrey had two wives, both Welsh girls, whom he carried off, but married. Gough, in his history of Middle, says: "Humphrey Kynaston had two wives, but both of soe mean birth that they could not claim to any coat of arms." By the first he had a son, Edward, who died young. By the second he had three sons, Edward, Robert, and Roger. If tradition may be trusted he proved so brutal and so bad a husband that his second wife left and returned to her kinsfolk in Wales. His son Edward was heir to the last Lord Powys, and continued the succession. Humphrey's elder brother died without lawful issue, and the honours and estates of the family devolved on Edward, upon his father's death in 1534 .

Now the laws relating to the marriage of Englishmen with Welsh women were still in force. 'The English Parliament, in 1401, had passed a series of the most oppressive and cruel ordinances ever enacted against any people; prohibiting marriage between English and Welsh, and disfranchising and disqualifying any Englishman from holding or inheriting property, if he had married a Welsh woman, and closing all schools and learned professions to the Welsh. These infamous laws had been reenforced by Parliament in 1413, and were not repealed when Henry VII. came to the throne, as might have been 273 


\section{ROBBERS' DENS}

anticipated. But Henry granted the Welsh a charter, which rendered the administration less rigorous. These tyrannous laws were not repealed till 1536. Now, the fact that Humphrey's marriage with Welsh women stood against him in no way justified his treatment of his wives.

Deserted by his second wife, Wild Humphrey was assisted by his mother, who came to Ruyton, in the neighbourhood, and carried him food on Sunday, a day of civil freedom.

On one occasion when he had been committing his usual depredations, on the further side of the Severn, the Under Sheriff at the head of a posse rode to arrest him, and for this purpose removed several planks of Montford Bridge, by which he was expected to return, and then laid in wait till he arrived. In due course Humphrey Kynaston rode to the Severn Bridge and prepared to cross. Thereupon the posse comitatus rose and took possession of the bridge end believing that they had him entrapped. But the outlaw spurred his horse, which leaped the gap, and he escaped. A farmer, who had been looking on, so the legend tells, called out, "Kynaston, I will give thee ten cows and a bull for thy horse." "Get thee first the bull and cows that can do such a feat," shouted the outlaw in reply, "and then we will effect the exchange."

'The leap of Kynaston's horse was measured and marked out on Knockin Heath, and cut in the turf, with the letters H. K. at each end.

The accession of a Welsh prince to the crown was in reality a fortunate thing for the Kynastons, especially for Wild Humphrey ; for ever since the rising of Owen Glendower, an Englishman who had married a Welsh woman was, as already said, legally disqualified from holding any office of trust, and from acquiring or inheriting land in England. Consequently Humphrey's issue by his Welsh wife might have been debarred from representing the family but for the accession of Henry VII. As it turned out, 274 


\section{ROBBERS' DENS}

since his elder brother left no issue, the son of Humphrey eventually inherited the family estates of the Kynastons.

Two and a half or three years after his outlawry, Humphrey was pardoned, 30th May 1493. The pardon is still extant, and is in the possession of Mr. Kynaston, of Hardwick Hall and Hordley, the present representative of the family. The direct line from Wild Humphrey expired in 1740 .

It is somewhat noticeable that in all the successive generations there was no further outbreak of the wild blood. The Kynastons descending from the outlaw, who was the terror of the countryside, were orderly country gentlemen, who did their duty and pursued harmless pleasures. Perhaps Wild Humphrey was rather a product of his lawless times, of the terrible disorders of the Wars of the Roses, and of the cruel law that blasted him and his issue, on account of his Welsh marriages, than a freebooter out of sporting propensities.

Tradition says that his continued misconduct and illtreatment of his wife kept her estranged from him. But on his deathbed he had one single desire, and that was to see her and obtain her pardon. He stoutly refused to be visited by any leech; and only reluctantly agreed to allow a "wise woman," who lived at Welsh Felton, near the scene of his old exploits at Ness Cliff, to visit him and prescribe herbs.

On her arrival, however, his humour had changed, and he impatiently turned away, saying, "I'll have none of your medicines. I want naught but my Elizabeth, my poor wronged wife."

"And she is here," answered the wise woman, throwing off her hood.

Humphrey turned and laid his head on her bosom, and without another word, but with his eyes on her face, breathed his last. 


\section{ROBBERS' DENS}

Is the story true or ben trovato? Who can say! It reposes on tradition.

Ness Cliff, the rock, in the face of which Humphrey Kynaston lived four hundred years ago, remains, with his cave, his flight of steps, up which ran his faithful horse, his stable, and the feeding trough, and the hearth on which burned Wild Humphrey's fire, very much as he left it. Only one feature is changed. There, from his rock, his eye ranged over the rolling woodland and open champagne country for miles so that he could see and prepare against the enemy who ventured to approach his stronghold; now it is buried in larch and Austrian pine plantations, so that nothing is visible from the cave, save their green boughs. It seems strange that for so many years he can have been suffered to continue his depredations without an attempt being made to surround his rock and keep him imprisoned therein till he was starved into surrender. But the explanation is probably this. He had made friends among the peasantry of the neighbourhood, whom he never molested, and to whom he showed many kindnesses; and they rewarded him by giving him timely warning of the approach of those bent on his capture, and thus enabled him to mount his horse, gallop away, and conceal himself elsewhere. Yet this only partly explains the mystery. If the cave were deserted, why did not the sheriff and his posse comitatus destroy the steps leading up into it, and thus render a retreat into it impossible? The only conclusion at which one can arrive is that the custodians of the law in the fifteenth century were half-hearted in the discharge of their duty, that there was a secret admiration for the wild outlaw in their hearts, and that they were reluctant to see the scion of a brave and ancient house brought to the gallows.

Some men have become predatory animals, and as such seek out lairs as would the beasts of prey.

The Chinaman possesses an instinctive reversion to old 276 


\section{ROBBERS' DENS}

subterranean life. Wherever he goes, wherever he succeeds in forming a "China-town," he begins to burrow and undermine the houses in which he and his fellow-countrymen live, and a labyrinth of passages and chambers is constructed, communicating with the several dwellings, so that a criminal Chinaman can rarely be trapped in the native quarter by the police. When San Francisco was burnt, the ground under the Chinese town was found to be honeycombed with runs and lurking-holes to an astounding extent.

When David had to escape from the pursuit of Saul, he fled first of all to Gath, but being recognised there, he made his way to the cave of Adullam. "And every one that was in distress, and every one that was in debt, and every one that was discontented, gathered themselves unto him, and he became a captain over them; and there were with him about four hundred men." I In a word, he became the head of a party of freebooters, who laid the neighbourhood under contribution.

The Palestine surveyors have identified the cave of Adullam with one now called by the peasants Aid-el-Ma. It lies in a round hill about 500 feet high, pierced with a number of caverns; the hill itself being isolated by several valleys and marked by ancient ruins, tombs, and quarryings. "A cave which completes the identification exists in the hill. It is not necessary to suppose that the one used by David was of great size, for such spacious recesses are avoided by the peasantry even now, from their dampness and tendency to cause fever. Their darkness, moreover, needs many lights, and they are disliked from the numbers of scorpions and bats frequenting then. The caves used as human habitations, at least in summer, are generally about twenty or thirty paces across, lighted by the sun, and comparatively dry. I have often seen such places with their roofs blackened by smoke: families lodging in one, goats,

11 Sam. xxii. 1-2. 


\section{ROBBERS' DENS}

cattle, and sheep, stabled in another, and grain or straw stored in a third. At Adullam are two such caves in the northern slope of the hill, and another further south, while the opposite sides of the tributary valley are lined with rows of caves, all smoke-blackened, and mostly inhabited, or used as pens for flocks and herds.

"The cave on the south of the hill itself was tenanted by a single family when the surveyors visited it, just as it might have been by David and his immediate friends, while his followers housed themselves in those near at hand." 1

The haunts of the bandits in the times of Herod must have been very much like those in Dordogne. 'They were high up in the face of precipices in Galilee, and he was able only to subdue these gangs of freebooters by letting his soldiers down in baskets from the top of the cliffs, with machines for forcing entrance. ${ }^{2}$

Stanley says ${ }^{3}$ : "Like all limestone formations, the hills of Palestine abound in caves. In these innumerable rents, and cavities, and holes, we see the shelter of the people of the land in those terrible visitations, as when 'Lot went up out of Zoar, and dwelt in a cave.' Or as when 'in' the days of Uzziah, King of Judah, they fled before the earthquake to the ravine of the mountains;' to the rocky fissures, safer, even though themselves rent by the convulsions, than the habitations of man. We see in them, also, the hiding-places which served sometimes for the defence of robbers and insurgents, sometimes for the refuge of those of whom 'the world was not worthy;' the prototypes of the catacombs of the early Christians, of the caverns of the Vaudois and the Covenanters. The cave of the five kings at Makkedah; the 'caves, and dens, and strongholds,

1 Geikie (C.), "The Holy Land and the Bible," Lond. 1887, i. p. 108.

2 Josephus, "Antiq.," xiv, 6.

3 "Sinai and Palestine," 1856, pp. 148-149. 


\section{ROBBERS' DENS}

and 'rocks,' and 'pits,' and 'holes' in which the Israelites took shelter from the Midianites in the time of Gideon, from the Philistines in the time of Saul; the cleft of the cliff Etam, into which Samson went down to escape the vengeance of his enemies; the caves of David at Adullam and at Maon, and of Saul at Engedi; the cave in which Obadiah hid the prophets of the Lord; the caves of the robber hordes above the plain of Gennesareth; the sepulchral caves of the Gadarene demoniacs; the cave of Jotopata, where Josephus and his countrymen concealed themselves in their last struggle, continue from first to last what has been called the cave-life of the Israelite nation."

The vast grotto of Lombrive in Ariège has been already mentioned. It became a den of a band of murderous brigands at the beginning of the nineteenth century. A detachment of soldiers was sent to dislodge them in 1802; to reach the great hall access is had by crawling through a narrow passage, and here the robbers murdered as many as 146 of the soldiers, taking them one after another as they emerged from the passage, and cutting their throats. ${ }^{1}$ The passage now bears the name of that of Du Crime.

The Surtshellir in Iceland has attracted a great deal of attention, perhaps because it is so different from other caves, being formed in the lava. Its origin is very easily explained. At a great eruption of lava from a neighbouring crater, the crust hardened rapidly whilst the viscid current below continued to flow, and this latter flowed on till it also became rigid, and left a great gap between it and the original crust. I visited it in 1860 . It has several branches, and in it lie pools perpetually frozen. There are gaps here and there in the roof through which rays of light penetrate, and also snow that heaps itself on the floor. In one sidechamber is a great accumulation of sheep-bones. In the thirteenth century a band of twenty-four robbers took up

$$
1 \text { "Spelunca," Paris, 1905, t. vi. p. } 169 .
$$




\section{ROBBERS' DENS}

their abode in this cavern, and made excursions in all directions around, robbing farmhouses, and driving away sheep. When this had gone on for some time the bonders united and succeeded in surrounding the gang, and killing eighteen of them. The six who escaped fled to the snow mountains, and were never heard of again. Now the strange thing is, how could the men live through a winter in this horrible cavern with a floor of ice in many places, and with a temperature below freezing even in summer? Fuel they could not procure, as there are but black sandy moors around that grow nothing but dwarf willow, and that is so scarce as to be inefficient for their purpose. 'They must have supplied themselves with light and heat by the tallow of the sheep they killed, run into a lamp. This is the only heating fuel used at present by the Icelanders, apart from the animal heat they give out in the closely sealed common room they occupy as sleeping quarters as well as diningroom and workshop. It may be vastly pleasant in theory to live at other people's expense, but it has its drawbacks, and in this instance le jeu ne valait pas la chandelle.

In Pitscottie's "Chronicles of Scotland," and in Holinshed's "Scottish Chronicle," at the end of the reign of James II. there is a story of a brigand who is said to have lived. in a den called Feruiden, or Ferride's Den, in Angus, who was burnt along with his wife and family for cannibalism, the youngest daughter alone was spared as she was but a twelvemonth old. But. when she grew up she was convicted of the same crime, and was condemned to be burnt or buried alive.

I have given elsewhere a very full account of the cavea den of robbers beside which that to which Gil Blas was cnrried was a paradise-La Crouzate on the Causse de Graniat in the Department of Lot. I will therefore here mention it but superficially. At the entrance are notches in the rock, showing that at one time it was closed by a door. A rapid descent is suddenly brought to a standstill 280 


\section{ROBBERS' DENS}

by an opening in the floor of a veritable oubliette, and this opening is crossed only by a bridge of poles, the hand helping to maintain the balance by pressing against the wall of rock on the right hand. Then comes a second hollow, but not so serious, and then a third that can only be descended by a ladder. This opens into a hall in the midst of which yawns a horrible chasm, across which lies a rough bridge of poles that give access to some small chambers beyond, which had formerly been tenanted by the brigands who had their lair in this cavern. Notches in the walls of the well show that across it were laid poles that sustained a pulley, by means of which a bucket could be let down to the well 265 feet, for water. My cousin, Mr. George Young, actually found remains of the crane employed for the purpose at the bottom of the well. About the year 1864, M. Delpons, prefect of the Department of Lot, observing a huge block of limestone lying in a field near La Crouzate, had it raised, and discovered beneath it twelve skeletons ranged in a circle, their feet inwards, and an iron chain linking them together; probably the remains of the bandits who made of La Crouzate their den, whence they issued to rob in the neighbourhood. According to the local tradition, the peasants of the surrounding country paid a poll-tax for every sheep and ox they possessed so as to raise a levée which should sweep the Causse of these marauders, and it was due to this effort that the band was captured and every member of it hung to the branches of the walnut tree beneath which lies the broad stone.

At Gargas, near Montzéjeau, in Hautes Pyrenées, is a prehistoric cavern of considerable extent. In it have been found sealed up in stalagmite the remains of primitive man. Now the significant fact exists that just ten years before the outbreak of the French Revolution this cave was inhabited by Blaise Ferrage, a stone-mason, who at the age of twenty-two deliberately threw aside his trade 281 


\section{ROBBERS' DENS}

and retired into the grotto, whence he sallied forth to seize, murder, and eat children and young girls. Men also he shot, strangled, or stabbed, and dragged to his lair, there to devour their carcases.

For three years this monster terrorized the countryside. The number of his victims was innumerable. As last he was caught and broken on the wheel in December 1782. There is no evidence that the naked prehistoric men who had inhabited the cave of Gargas were cannibals.

That the outlaw and he who has dropped out of the ranks of ordered social life, and he who seeks to prey on civilised society should naturally, instinctively, make the cave his home, is what we might expect. He is reverting to the habits of early man whose hand was against every man.

In the "Two Gentlemen of Verona," the outlaws are presented as living in a cave. The robbers in "Gil Blas" had their lair also in one.

One of the finest and most pathetic of Icelandic Sagas is the history of Grettir the Outlaw, who was born in 997 , and killed by his enemies in 1031. He spent nineteen years in outlawry in Iceland, and outlawry there in that terrible climate, with no house to cover his head, would seem an ordeal impossible for human endurance. Between the autunin of 1022 and the spring of 1024, that is to say during two winters, he lived in a cave in the west of the island. A steep shale slide was below a cliff, and above this a hollow in the rock. He built up the mouth of the cave, and hung grey wadmal before the entrance, so that none below could notice anything peculiar, or any one living there. Whatever fuel he wanted, all he had to eat, everything he needed, had to be carried up this slippery ascent by him. Down the shale slide he went when short of provisions, and over the marshes to this or that farm and demanded or carried off, sometimes a sheep, sometimes curds, dried fish-in a word what he required. 


\section{ROBBERS' DENS}

In the summer of 1862 a very similar lair which Grettir inhabited a little later in the east of Iceland was explored by a farmer living near. This is his description of it: "The lair stands in the upper part of a slip of stones beneath some sheer rocks. It is built up of stones, straight as a line, four and three-quarter ells long and ten inches wide, and is within the walls seven-eighths of an ell deep. Half of it is roofed over with flat stones; small splinters of stone are wedged in between these to fill up the joints, and these are so firmly fixed that they could not be removed without tools. One stone in the south wall is so large that it would require six men to move it. The north wall is beginning to give way. On the outside the walls are overgrown with black lichen and grey moss."

A chapman spending the winter in a farm hard by, named Gisli the Dandy, heard that a price of nine marks of silver was placed on the head of Grettir. "Let me but catch him," said he, "and I will dress his skin for him."

The outlaw heard of this threat, and one day looking down from his rock he saw a man with two attendants riding along the highway. His kirtle was scarlet, and his helmet and shield flashed in the sun. It occurred to Grettir that this must be the dandy, and he at once ran down the slide of stones, clapped his hand on a bundle of clothes behind the saddle, and said, "This I am going to take." Gisli, for it was he, got off his horse, and called on his men to attack Grettir. But the latter soon perceived that the chapman kept behind his servants, and never risked himself where the blows fell: so he put the two thralls aside and went direct upon the merchant, who turned and took to his heels. Grettir pursued him, and Gisli, in his fear, threw aside his shield, then away went his helmet, and lastly a heavy purse of silver attached to his girdle. Presently the flying man came to a bed of old lava full of cracks. He leaped the fissures and reached a river that flowed beyond. There he 283 


\section{ROBBERS' DENS}

halted, unable to make up his mind to risk a plunge into it, and that allowed Grettir to run in on him and throw him down.

"Keep my saddle-bags and what. I have thrown away," pleaded the fallen man, "only spare my life." "There must be a little skin-dressing done first," answered Grettir. 'Then he took a good handful of birch rods from the wood, pulled Gisli's clothes up over his head, and laid the twigs against his back in none of the gentlest fashion. Gisli danced and skipped about, but Grettir had him by his garments twisted about his head, and contrived to flog till the fellow threw himself down on the ground screaming. Then Grettir let go, and went quietly back to his lair, picking up as he went the purse and the belt, the shield, casque, and whatsoever else Gisli had thrown away. Also he retained the contents of his saddle-bags. ${ }^{1}$

At Dunterton, on the Devon side of the 'lamar, is a headland of rock and wood projecting above the river, and in this is a cave. In or about 1780 there was a man, the terror of the neighbourhood, who lived in this cave, but that he was there was unknown. He was wont to "burgle" the houses of the gentry round, and his favourite method of proceeding was to get on the roof and descend the chimneys, which in those days were wide. In my hall chimney was, till I removed it, an apparatus fitted with sharp spikes upward to impale the burglar should he attempt to get into the house that way. In the house of a neighbouring squire a funnel was made into which he might drop, and from which he could not escape. He was finally discovered by Colonel Kelly, when drawing the wood with his hounds; as the cave was held to be the den of the ogre, it was looked upon with fear, and was also long the lair of smugglers.

Perhaps the latest cave-dwelling criminal was Carl 1 "Grettir Saga," Copenh. 1859. "Grettir the Outlaw," Lond. 1890. 284 


\section{ROBBERS' DENS}

Friedrich Masch, who before his execution confessed to having committed twelve murders and to having attempted several more. This man carried on this warfare against society from 1856 to 1864 , that is to say for eight years, in Prussia. His presence in the district was always suspected rather than ascertained, by the numerous cases of arson, burglary, and robbery, as well as by murders and murderous attacks. One of his worst crimes was the butchery of a whole family, a miller, his wife, three children, aged respectively twelve, ten, and five, and a young servantmaid in 1861. In vain were large rewards offered for the capture of Masch; if he had confederates they were not bribed to betray him, and the police were powerless to trace him. Even soldiers were called out to search the forests, but all in vain, and he was not captured till 1864 when he was arrested when tipsy in the street of Frankfurt on the Oder, and then it was not till some hours later that it was discovered he had but just committed a fresh murder.

In March 1858 a miller named Ebel went into the Pyritz forest near Soldin, along with his servant-man to fetch away firewood he had purchased. After having laden his wagon he sent it home under the conduct of his man, and remained behind among the trees. He looked about among the bushes to find a suitable branch that he could cut to serve as a walking-stick. Whilst thus engaged he came on some rising ground overgrown with young birch, and on the slope of the hill not more than. 200 paces from the much-frequented highroad he noticed a spot where the snow was beaten hard, as if it had been the lair of a wild beast. To get a better sight of this, Ebel parted the bushes and came closer. Then he was arare of a patch of dried leaves uncorered by snow. Unable to account for this, he stirred the leaves with his recently cut stick, and to his surprise saw them slide down into the earth as into 285 


\section{ROBBERS' DENS}

a funnel. More puzzled than ever he began to examine the locality, when he noticed that the ground under his feet sounded hollow, and that there was hard by a second and larger hole. As he stood staring at this, suddenly a cudgel appeared followed by the white face of a man with black hair and beard and dark piercing eyes, rising out of the ground. For a moment Ebel stood paralysed with terror, and then, as the man was heaving himself to the surface, he beat a hasty retreat.

When he reported what he had seen to the forester and some wood-cutters, he was at first not believed, but he insisted that they should accompany him to the spot. They did so, and this is what they found: a board, covered with earth, but with a hole in the midst, through which a couple of fingers could be thrust so as to bring it from below into position, had been used to cover the entrance to an underground habitation. Jumping into a pit, a passage was seen about five feet high, in which a stove had been placed, and the hole the miller had seen, into which the leaves had fallen, was the chimney. Further on was a chamber seven feet long by seven feet broad, and five feet high, that had clearly served as a dwelling for some considerable time. It was full of clothing, linen, an axe, a hammer, a bunch of keys, and an assortment of burglar's tools. 'The roof was supported by posts and transverse beams, and from them hung legs of pork, bacon, and sausages. 'There was also a cellar well stocked with wine and brandy, and even champagne. A bed was fashioned of birch boughs and fir branches and hay. The boughs protected from the damp of the soil. Great quantities of bones of pigs, sheep, geese, and other poultry were found buried in the sides of the passage and about on the surface.

The forester reported to the police what he had seen. A good many of the articles found were reclaimed by peasants 286 


\section{ROBBERS' DENS}

who had been robbed; but the denizen of the cave-dwelling had vanished, and returned no more. At the same time, attacks on persons and property ceased in that neighbourhood, but began in the neighbourhood of Berlin. But in the spring of 1859 they were renewed in the district of Soldin. The military were ordered to manœuvre, surround, and traverse the woods, and search every moor. All was in vain, not a trace of the perpetrator of these crimes could be found, and no sooner were the soldiers withdrawn than a taverner and his young wife were discovered in their little inn, with their heads beaten in, and their throats cut, and the man's watch and his money taken. This was followed by the murder of a peasant girl, on the highroad, as she was returning from saying farewell to her lover who had to leave his village for military service. Next came the slaughter of the miller and his family. Renewed efforts to trace the murderer were made and were equally fruitless.

A toll-keeper was fired at in his bed and severely wounded. The would-be assassin had drawn a cart into position, placed boards on it, raised an erection on the boards to support himself so as to be able to take aim at the sleeping man through the window. He could see where he was, as a light burned in the room. He was prevented breaking into the house and murdering the wife and child by the approach of passengers. A farmer was shot at and also badly hurt when returning from market, and only saved from being killed and robbed by his horse taking fright and galloping out of reach.

A further hiding-place of Masch was discovered by accident, as was the first, in May 1861, in the neighbourhood of Warsin. It was more roomy than the first, constructed with more art, was also underground, and contained innumerable objects that had been stolen; amongst others a little library of books that Masch could read in the long winter evenings to pass away the time. 


\section{ROBBERS' DENS}

When after eight years of this sort of life, he was finally arrested, he was brought to confess his crimes. And one portion of his narrative concerned his place of concealment in the winter of 1858-59, before he had dug out his subterranean abode at Warsin, and after the discovery of his den at Pyritz.

That was also spent underground, but not in a cave of his construction. I will give the account in his own words.

"The winter came on and I had no money and no place of refuge against the cold. It was only when a hard frost set in that I found an asylum in the culvert constructed to carry off the water from the Bermling lake. The canal consists of a stone-built tunnel, the entrance to which is closed by closely-set iron stancheons. But accustomed as I was, like a cat, to contract and wriggle through narrow spaces, I succeeded in forcing my way in and I formed my lair on the solid ice. Before a fall of snow I provided myself with food, wine, brandy, clothing, and bedding, but I was constrained to spend many weeks in my hiding-place lest I should betray it by my footprints in the snow. My abode there was terribly irksome, for the culvert was not lofty enough to allow one to stand upright in it, and I was constrained to wriggle about in it, crawling or thrusting myself along with hands and feet. I had indeed covered my legs with leather wound about them, but my limbs became stiff. Sitting on the ice was almost as uncomfortable as lying on it. An upright position when seated became unendurable with my legs stretched out straight before me. Accordingly I hacked a hole through the ice into the frozen mud, and thrust my legs down into it. But my blood chilled in them, and my legs would have been frozen in, had I not withdrawn them and stretched them out as before, 'well enveloped. Moreover I could not sit with my back leaning against the ice-cold stone walls, and the 288 


\section{ROBBERS' DENS}

air in the tunnel was dense and foggy. As soon as the ground was clear of snow I escaped from my horrible prison, and enjoyed myself in the open, but for safety had to retreat to it again. On one occasion I narrowly escaped discovery. The owner of the estate hard by and his son were out one day with their hounds. These latter rushed to the entrance of the culvert and began snuffing about at it. Their masters observed this, and made the brutes enter the tunnel. I crouched, my loaded gun in my hand, and peered betwixt the iron bars. If one of the hounds had come near me, I would have shot it. Happily the beasts did not venture far in, probably on account of the heavy vapour they had lost the scent. They withdrew, and I remained in my cellar-dwelling till the spring. When the ice melted and the mud became soft, I had to quit my winter quarters. I had suffered so unspeakably that I resolved without more ado to excavate for inyself a new habitation underground which in comparison with the culvert seemed a paradise to me." 1

Masch was executed on 18th July 1864.

A picturesque walk through the woods near Wiesbaden on the Taunus road leads to the Leichtweishöhle, a cave under a mass of fallen rock, in the Nerothal. The cave measures 100 feet in length, and at its entrance and exit are now set up portraits of the former occupant of this retreat and his mistress. Within, in a side chamber, is the bedroom of the robber, and his bed, that was covered with dry moss. In the midst of the cave is a round, massive stone table, and under its foot is a pit excavated to receive his money and other valuables. The cave, now accessible, is an object of many a pleasant excursion from Wiesbaden; over a century ago it was in a dense and pathless forest, the intricacies of which were unknown.

Henry Antony Leichtweiss was born in 1\%30 at Ohrn, and

1 Der neue Pitaral, Leipzig; neue Serie, ii. 1867, pp. 104-105.

289 


\section{ROBBERS' DENS}

was the son of a forester in the service of the Duke of Nassau. He was put apprentice to a man who was at once a baker and a besom-maker, and he learned both professions with readiness. Being a well-built, handsome youth, he managed to get engaged as courier in a noble family, and in the situation made many journeys and learned to know the world, and also to lay by some money. In September $\mathbf{1 7 5 7}$ he married the daughter of the magistrate (Schultheiss) of Dotzheim, and he obtained appointment under him as scrivener. By his wife he had seven children. On the death of his father-in-law, and the appointment of a new magistrate, the aspect of his affairs changed. He was detected in attempts to appropriate trust-money to his own use, and was dismissed his office. He sank deeper and deeper, and was arrested and imprisoned at last for theft. On leaving Wiesbaden, where he had been confined, he returned to Dotzheim, but there no one would have anything to say to him, and his own wife refused to receive him into her house.

Leichtweiss now gave himself up to a vagabond life, and as he had of old been associated with the chase, he turned to poaching as a resource. The wide stretch of forests of the Taunus, well stocked with game, and the proximity to such markets as Frankfort and Mainz, offered him a prospect of doing a good business in this line. He managed to induce a wench to associate herself with him, and he dug out a cave of which the description has already been given, in which he made his headquarters, and where he lived and carried on his depredations unmolested for seven years. The spot was so secret and the confusion of rocks there was so great, that he trusted never to be discovered. The main danger lay in smoke betraying him when his fire was lighted, or of his track bring followed in the snow during the winter. But, as already said, for seven years he remained undiscovered, although the keepers of the Duke were well 290 


\section{ROBBERS' DENS}

aware that the game in the forests was being shot down and disposed of in the town, and although villagers declared that he had stayed and robbed them. These allegations were, however, never proved. When he was at last captured, he was tried and sentenced to be placed in the stocks at Wiesbaden in the market. Two days after he hung himself in prison.

In the chapter on Souterrains I have spoken of the Adersbach and Wickelsdorf rock labyrinths, without mentioning that they have served as a haunt for robbers. I will now deal with them from this point of view. Take a piece of veined marble, and suppose all the white veins of felspar washed clear, leaving the block cleft in every direction from top to bottom, and all the cleavages converging to one point and through that one point only, on the Wickelsdorf side, is access to be had to the labyrinth. But then conceive of the block thus fissured towering three hundred feet or more sheer up, and having narrow rifts as the passages by which the interior may be penetrated. In the eleventh century sixty knights of the army of Boleslas III., when the latter was driven back by the Emperor Henry II., took refuge in the neighbourhood of Trauterau, and built there a castle, and subsisted on robbery. The captain was a Pole named Nislaf. As they prospered and multiplied, Nislaf divided his company, and placed one portion under Hans Breslauer, who said to his men, "IVe have a treasure-house in these rocks, only unhappily it is empty. We must pillage the merchants and travellers, and fill it." Nislaf's party fell out with one another, and one, named Alt, led off the discontented and built a fortress, the remains of which may be traced at the highest point above the Adersbach labyrinth. One day the crowing of a cock betrayed where Nislaf had his abode, and troops were sent from Prague to clear the country. Most of the bandits were captured and executed. 


\section{ROBBERS' DENS}

In the early part of the nineteenth century a notorious ruffian at the head of a gang lurked in this neighbourhood. His name was Babinsky.

One evening, in the autumn of 1839 , a carriage drew up at the outskirts of the Dobrusch forest. A couple of ladies descended from it at the door of a tavern, and asked the Jewish landlady if they could be accommodated with supper and a bed. "We are afraid to proceed," said one of the ladies, "for fear of Babinsky." "Babinsky," answered the hostess, "has never shown his face here."

The ladies were shown into a plain apartment, but were made uneasy by seeing a number of ferocious looking men in the passage and bar. "Who are these?" asked the lady. "Only packmen," replied the landlady. After supper the two ladies were shown into a large bedroom in which at one side was an old-fashioned wardrobe. When left alone they examined this article of furniture, and perceived an unpleasant odour issuing from it. By some means or other they succeeded in forcing open the door, when they perceived that at the bottom of the wardrobe was a trap-door. This they raised, and to their dismay discovered a well or vault, out of which the umpleasant odour issued. They now set fire to some newspaper, and threw it down the hole, and to their unspeakable horror saw by the flames a halfnaked corpse. The ladies closed the trap and considered. It was clear that they were in a murderous den, probably controlled by Babinsky. The youngest lady, who had most presence of mind and courage, descended the stairs, opened the guest-room, and said to her coachman, "Hans, it is now half-past nine. 'This is the hour at which Captain Feldegg, my brother-in-law, promised to start at the head of a military escort to conduct us through the forest. We will leave as soon as you can harness the horses to save him the trouble of coming on so far as this."

Hans finished his glass of wine and rose. The men in 292 


\section{ROBBERS' DENS}

the guest-room looked at one another. Before half-an-hour had elapsed the carriage rolled away, and next morning the police were communicated with. It need hardly be said the ladies met with no escort.

A few days later a middle-aged, ragged fellow, with a grinding organ, arrived at the inn, and called for a glass. In the guest-room were the "packmen," and some equally wild-looking girls. The grinding organ was put in requisition, and to its strains they danced till past midnight, when Babinsky himself entered and the dancing ceased. The organ-grinder had so ingratiated himself into the favour of the robbers, that they resolved on retaining him as the musician of the band. He was conveyed across country till they reached some such a rocky retreat as that of Wickelsdorf or Adersbach, and there spent three weeks, only allowed to accompany the band when they were going to have a frolic. On these occasions they betook themselves to the resort agreed on, by twos and threes. One day as some of them passed along a road, they saw a blind beggar in the hedge, asking for alms. Some cast him coppers, and the organ-grinder slipped into his hand a kreutzer, wrapped in a bit of paper.

That night the tavern was surrounded by the military, and the whole gang, along with Babinsky, was captured. This was on 15th October 1839. The organ-grinder was the Prague detective Hoche.

The trial dragged on for several years; some of the robbers were executed, some sentenced to ten, others to twenty years of imprisonment. No evidence was produced that actually convicted Babinsky of having committed, or been privy to the murders, and he was sentenced to penal servitude for life.

I was rambling in Bohemia and tracing the Riesen Gebirge in 1886. On reaching home I read what follows from the Vienna Correspondent of the Standard. "At the 293 


\section{ROBBERS' DENS}

little market town of Leitomischl in Bohemia," at the foot of the continuation of the Giant Mountains I had been exploring, " an innkeeper and his wife and son have just been arrested by the police on a charge of having, during the last twenty-five years, murdered no fewer than eleven persons. The victims were all travellers who had put up for a night at his house, and who had shown that they were in possession of ready cash. For a considerable time the suspicions of the police had been aroused by the sudden disappearance of various visitors staying at this inn. Among the latest cases was a cattle dealer who, after visiting the market, was returning home with the proceeds of the sale of a herd of cattle, and a young baron who had won a large sum in a public lottery. After putting up at the inn in question, these men, like others before them, were never heard of again. 'The very last case was that of the sudden disappearance of a lady, who was undoubtedly murdered and robbed by the arrested persons."

I did in fact find the inns in Bohemia, in certain places infested, but not with bandits and cut-throats. 


\section{CHAPTER XII}

\section{ROCK SEPULCHRES}

NOTEWORTHY distinction exists between the count-
less rock-tombs in Palestine and those equally countless
in Egypt. In the former there has not been found a single inscription to record the name of the occupant, whereas among the latter not one was umnamed.

The reason probably was that the Jew had no expectation of existing in a state after death, and those of his family he put away in their holes in the rocks had ceased to be to him anything more than a recollection. All his hopes, his ambition, were limited to this life and to the glorification of his nation. The highest blessing he could personally reckon on was that his days might be long in the land which the Lord his God would give him.

The horizon of the Egyptian, on the other hand, was full of anticipation of a life of the spirit when parted from the body. "Instead of the acres of inscriptions which cover the tombs of Egypt," says Dean Stanley, "not a single letter has been found in any ancient sepulchre of Palestine."

When the Israelites escaped from the iron furnace of Egypt, they carried with them so intense an abhorrence of all that savoured of Misraim that they put away from them polytheism and repudiated idolatry; they swept away as well the doctrine of life after death, such as dominated the Egyptian mind, that they might focus all their desires on this present life.

"Let me bury my dead out of my sight," expressed the feeling of the Israelite before and after the Exodus. 


\section{ROCK SEPULCHRES}

The patriarchs had no conception of the resurrection of the body. The idea was unknown to them. Their faith did not even embrace a belief in the immortality of the soul. A passage in Job (xix. 25-27) has been adduced to prove the contrary, but it does so only because it is a mistranslation, and was manipulated by the translators according to their own preconceptions. Even the word rendered Redeemer has no such signification, it means "the Avenger of Blood." It was probably through contact with other nations that had a wider hope, that slowly and haltingly the conception of a prolonged existence after death made its way among the Jews.

Christianity invested the body with a sacredness undreamt of under the Old Covenant, and gave assurance, not of a continued existence after death alone, but of a resuscitation of the body. "If in this life only we have hope in Christ, we are of all men most miserable." "As in Adam all die, even so in Christ shall all be made alive."

The Jews entertained a strong aversion towards incineration, because the latter was a pagan usage, and they gloried in their singularity. In Rome they had their catacombs hewn out of the rock, and the Christians followed their example.

A short time before the Christian era, Judea had been made tributary to Rome by the victories of Pompey, and many thousands of Jews were transferred to Rome, where a particular district was assigned to them on the right bank of the Tiber. We know how tenaciously Jews clung to their religion and to their traditional practices, and they sought to lay their departed members in rocky sepulchres, such as those of their distant country. And, in fact, outside the Porta Portese, the gate nearest to their quarter of the town, a Jewish catacomb exists, discovered in 1602, excavated in Monte Verde, that contains the tombs of the Hebrews. Irom this all emblems exclusively Christian 296 


\section{ROCK SEPULCHRES}

are absent. There are representations of the Ark of the Covenant, of the seven-branched candlestick. 'The lamps also were impressed with the same symbols; and in a fragment of a Greek inscription is traced the word "Synagogue."

The catacombs of the Christians resembled those of the Jews in every other particular.

Three different kinds of stone compose the basis of the Roman Campagna; the tufa litoide, as hard and durable as granite, used extensively for building purposes; the tufa granolare, which is consistent enough to retain the form given to it by excavators, but it is useless as building material, and lastly the Pozziolana, largely employed in the making of Roman cement. Neither the arenaria or sand quarries, nor those for the building stone were ever employed for excavation to make catacombs, whereas the granular tufa has been so largely excavated for this purpose that if the galleries were continued in one line, it has been reckoned that they would stretch the entire length of the Italian peninsula. They form a labyrinth of passages and cross-passages, and are moreover in several stages called piani. But they do not extend far from the Eternal City, not beyond the third milestone. The galleries have a breadth of from two to four feet, and their height is governed by the nature of the rock in which they are hewn. The walls on both sides are lined with graves dug out of the rock, in a horizontal position, one above the other, like bunks in a cabin. In each of these reposed one or more bodies. Here and there the sequence is broken by a cross-passage that leads to a small chamber, and in these chambers the sides, like those of the galleries, are perforated with graves. All these graves were originally closed by slabs of marble or tiles. This is about the only distinction between the graves of the rich aud those of the poor, of the slave from his master. Those who desired to set some 297 


\section{ROCK SEPULCHRES}

mark on the resting-place of a relative, to distinguish it from those around, either had the name engraved upon the slab, or rudely scratched with the sharp end of a trowel in the mortar by which the slab was secured, or else a bit of ornamented glass or a ring or coin was impressed in the mortar while it was still wet.

The martyrs in many cases were accorded a more elaborate grave. They were laid in a sarcophagus in an arcossolium, and on the covering slab the Holy Mysteries were celebrated on the anniversary of their martyrdom. But sometimes a wealthy family had its own chamber, cubiculum, reserved for its members.

The puticoli, of which mention has already been made as ash and refuse pits, were of a totally different description. They were funnel-shaped shafts sunk in the rocks, the narrow orifice being on the level of the ground. Into this were precipitated the carcases of slaves and of the poor. Indeed, they are still in use at Naples, when a cart with a lantern may be followed till it reaches the place of interment, where a hole gapes. The corpse that is enveloped in a shroud only, is shot down into the hole, without its winding sheet, that is reserved for further use.

But to return to the catacombs. There are not only over thirteen in the neighbourhood of Rome, but they are found also at Otricoli, Soriano, Spoleto, Vindena, Chiusi, Lucca, Castellamare, Prata by Avellino, Aquila, Puzzuoli, Baiæ, Nola, Canesa, Tropea, Manfredonia, Venisa-this last perhaps Jewish. 'There are five sets of them at Naples. Others in Malta. In Spain at Ancona, Siviglia, and Elvira. In France is the hypogee opening out of the early church of S. Victor at Marseilles. In Germany is one at Trèves. In Hungary at Fünfkirchen. One in the Greek island of Melos, at Alexandria also, and at Cyrene. One at Salamis in Cyprus. The catacombs of Syracuse are like those of Rome, of vast extent. They have lofty vaults very superior to the narrow 298 


\section{ROCK SEPULCHRES}

gangways of the cemeteries of Rome. A broad gallery runs athwart the whole labyrinth, and from this branch out innumerable passages. One large circular hall is lighted from above. Along the sides are niches that served as sepulchres. Paintings as at Rome decorate the walls and vaults, all of an early Christian character, representing men and women in the attitude of prayer, the peacock, and the sacred monogram.

Numerous inscriptions from the tombs are collected in the museum of Syracuse.

The catacombs of Paris are not of ancient date as catacombs. They were originally, like those of Syracuse, quarries for the construction of the calcaire grossier for building the city, down to the seventeenth century. They extend under the communes of Vauregard, Montrouge, and Gentilly on the left bank of the Seine, and it is said that a tenth part of Paris is thus undermined. In 1774, and again in 177\%, accidents occurred through the giving way of the crowns of the caverns, bringing down with them the houses built above. In the Boulevard Neuf a building near the Barrière d'Enfer suddenly sank into a hole 80 feet deep, and this drew public attention to the danger.

Until the end of the reign of Louis XVI. the principal burying-ground of Paris had been the Cemetery of the Innocents. Originally situated beyond the walls of the town, it had in due course been so surrounded by the growing metropolis as to render it impossible to continue its use as a cemetery, and in $1 \% 84$ the practice of burying therein was discontinued, the accumulated bones of Parisians were removed thence with great precaution, on account of the insalubrity of the operation, and they were deposited in the old quarries, and the catacombs were solemnly consecrated for their reception by the Archbishop of Paris on 7th April 178\%. A public market-place was then established on the site of the former cemetery. 


\section{ROCK SEPULCHRES}

To protect the town from settling down into this necropolis, vast sums were expended in substructures, so as to remove all danger of future collapse.

Gradually many other cemeteries that had been encroached upon, or surrounded, were required to yield up their dead, so that it was estimated that the catacomb contained the remains of three million persons. 'Ihe bodies of some victims of the Revolution were placed here as well.

For many years the bones remained as they were thrown down on their removal, in heaps, but after 1812 they were gradually arranged in a fantastic manner, and turned into an exhibition for the curious. Sixty-three staircases lead from the different parts of the town into the catacombs, and are used by workmen and agents appointed to take care of the necropolis. 'l'wice in the year tours of inspection are made by the surveyors, but visitors are no longer allowed access to the catacomb. There have occurred cases of men having been lost in the intricate labyrinth.

The crypts in which were laid the bodies of saints gave occasion to kings, princes, and great men employing like mausoleums.

'The poor and mean might lie in the earth, but men of consequence must have vaults in which the members of their families might be laid. What hideous profanation of sepulchres would have been spared had the kings of France been laid in the earth! 'They elected to repose in the crypt of the splendid minster of S. Denis. When the Revolution broke out, the Convention resolved that the tombs should be destroyed in accordance with the motion of Barrère, 31st July 1793, "La main puissante de la République doit éfiacer impitoyablement ces épitaphes superbes, et demolir ces mausolées qui rappeleraient des rois l'effrayant souvenir;" and "of the coffins of our old tyrants let us make bullets to hurl at our enemies." The 300 


\section{ROCK SEPULCHRES}

decree for the destruction was sacrilegiously executed; the coffins were opened-Henri II. and his queen in their robes, Henri IV. in a perfect state of preservation, Louis XIV. still recognisable. The body of Turenne, with the fatal bullet visible in it, was preserved as a peep-show. The rest were thrown into "fosses communes" dug in the neighbourhood. By a singular coincidence, the work of desecration was begun on 12th October 1793, the anniversary of the day on which, one hundred years before, Louis XIV. had caused the demolition of the tombs of the German Emperors at Spires. Not only so, but the agent employed by the Convention was Hentz, a namesake of the superintendent of the work of destruction carried out at Spires.

And thus the whirligig of time brings in his revengesLouis XI. escaped. He had been buried in a crypt at Cléry, and had been forgotten. In 1889 the abbé Saget, curé of Cléry, opened the vault and found the body intact. Louis XI. had this sepulchre made for himself during his lifetime. Now the risitor can take in his hand the head, and muse over it on the treachery, cunning, and cruelty that once lodged in that little brain-pan. Scott may have been incorrect in his history in "Quentin Durward," but he was accurate in his characterisation of the king.

The instinct of immortality is implanted in the human breast. The reverential care with which prineval man treated his dead, showed a confusion of ideas between soul and body. His senses told him, and told men in the historic period, that the body dissolved to dust, yet as a temple of the spirit it was treated with respect. The soul to the Egyptians was in some manner always related to the body. The " $\mathrm{ka}$ " must have something to which to return, if not to the mummy, then to its model.

The dead in the first ages were given the cares in which they had lived, but they began to press out the living, to monopolise all caves, and afterwards artificial dwellings 301 


\section{ROCK SEPULCHRES}

were reared to receive them, stone structures, dolmens, that were heaped over with earth, to make them resemble their former subterranean habitations. Sometimes these structural caves consist of a series of chambers connected by a passage, the so-called allées couvertes of France, but of which we have fine examples in Scotland and Ireland.

Where huge slabs of granite, limestone, or sandstone were not available, the living scooped out underground cemeteries, closely resembling their own underground dwellings.

In the Petit Morin are many of these that have been explored and described by the Baron de Baye. I have already spoken of the habitable caves there found. But there were sepulchral chambers excavated in the chalk as well. These differ from the others in that the entrances are blocked by a large slab, and in some instances have sculptured figures in them of the goddess of Death, or of a stone hammer.

The Norsemen buried their sea-kings in the ships in which they had sailed on their piratical expeditions. King Ring, when he slew Harold Hilditön, buried him in his chariot and with his horses. In Gaulish tombs such chariots have been found. The Scandinavians seem to have had but a confused idea of what death was; the dead were but in a condition of suspended animation. Hervör went to the isle of Samsey where, under a huge cairn, lay her father Angantyr and his eleven brothers who had fallen in single combat. Angantyr had been buried along with his sword 'Tyrfing.

When she reached the grave mound she sang:-

"Wake thou up, Angantyr!

Wakens thee Hervör

Thy only daughter.

Give from the grave mound

Freely thy good sword. 


\section{ROCK SEPULCHRES}

"Wake thou up Hervard!

Wake thou, Hjorvard!

Hrani, Angantyr !

Shake off your slumbers

Under the tree-roots."

From his grave Angantyr replies :-

"Hervör, my daughter,

Wherefore disturb me?

Full of temerity

Madly thou seekest

Dead men to waken."

But she persists. She will have the sword. Whereupon the cairn gapes, and she sees fire therein, and from out of the mound and flame the sword is hurled forth and falls at her feet. ${ }^{1}$

Grettir the Strong broke into the tomb of Karr the Old, an ancient Viking, to obtain his sword, and had to wrestle with the dead man before he could wrench it from him. ${ }^{2}$ I will quote another case of cairn-breaking that exhibits the same conception of suspended life in the grave, and that in Christian times. I shall slightly condense the story. "Gest started breaking into the mound in the day. At evening, with the help of the priest, he had got down to make a hole in the vault, but next morning it was all closed up again." T'o obviate this the priest watched all night by the cairn furnished with holy water. Next morning when Gest returned, the mound was as he had left it, and the two continued their operations. Gest was let down into the cavity, and the priest and other men held the rope. It was fifty fathoms down to the floor. Gest had a candle in his hand, and he now lighted it and looked about him. $\mathrm{He}$

1 “Hervarar Saga," Copenh. 1785.

2 "Grettir Saga," Copenh. 1859, chap. xviii. 303 


\section{ROCK SEPULCHRES}

saw a big ship with five hundred men in it, and they were all preparing to start up, but as the light of the (consecrated) candle fell on them none stirred, but they stared blankly and snorted. Gest smote at them to cut off their heads, but it was as though his sword passed through water. He cleared the dragon-ship of all its valuables and sent them up by the rope. Then he searched for Raknar (the Seaking whose tomb it was). He found a descent still further underground, and there he discovered Raknar seated on a throne. He was frightful to look upon, and the vault was both cold and stinking. A cauldron was uuder his feet full of treasure, and he had a torque about his neck, very resplendent, and a gold ring on his arm. He was in breastplate and helmet, and had a sword in his hand. Gest went up to Raknar and saluted him courteously in a song, and Raknar bowed in acknowledgment. Gest said to him : "I cannot commend your appearance at present though I can praise your achievements. I have come a long way in quest of you, and I am not going away unrewarded for my trouble. Give me some of what you have, and I will sing your renown far and wide." Raknar bowed his head to him, and allowed him to remove his helmet and breastplate. But when Gest attempted to deprive him of his sword, Raknar sprang up and attacked Gest. He found him neither old nor stiff. And now the consecrated candle went out. Raknar became so strong that Gest could hardly bear up against him; and all the men in the ship now rose up. Then Gest invoked his father Bard who appeared, but availed naught, then he called upon Him who had created heaven and earth, and vowed to accept the faith which King Olaf was preaching. Thereupon Olaf appeared in a blaze of light, and Raknar collapsed, with all his men. His power was gone from him. Whereupon Gest cut off his head and laid it at his thigh. At the apparition of King Olaf all the dead men who had stood up reseated 304 


\section{ROCK SEPULCHRES}

themselves on their benches. After that Gest removed all the treasures out of the tomb. 1

The cairn of the outlaw Gunnar was seen open occasionally. "Sharphedin and Hogni were out of doors one evening by Gunnar's cairn on the south side. 'The moon and stars were shining clear and bright, but every now and then the clouds drove over them. Then all at once they thought they saw the cairn standing open, and lo! Gunnar had turned himself in the grave-mound and was looking at the moon. They thought they saw four lights burning within, and none of them threw a shadow. They saw Gunnar, that he was merry, and wore a right joyful face. He sang a song, and that so loud it might have been heard though they had been further off." The song of the dead man is given, and then it is added: "After that the cairn was shut up again." 2

Helgi Hundingsbane was visited in his grave-mound by his wife Sigrun, who spent a night there with him. $\mathrm{He}$ informed her that all her tears fell on and moistened him. "Here Helgi have I prepared for thee in thy mound a peaceful bed. On thy breast, chieftain, I will repose as I was wont in thy lifetime." To which the dead Helgi replies: "Nothing is to be regarded as unexpected, since thou, living, a king's daughter, sleepest in a grave-mound, in the arms of a corpse." Next morning Sigrun departs. ${ }^{3}$

Saxo Grammaticus tells us a grimly tale. Asmund and Asvid, brothers in arms, had vowed not to be separated in death. It fell out that Asvid died, and was buried along with his horse and dog in a cairn. And Asmund, because of his oath of friendship, had courage to be buried with him, food being put in for him to eat. Now just at this

1 "Bartða Saga," Copenh. 1860, chap. xx.

2 "Nials Saga," chap. Ixxix., trans. by Dasent, Edin. 1861, chap. Ixxvii.

3 "Helgi Kr. Hundingsbana," ii. 45-47. 


\section{ROCK SEPULCHRES}

time, Eric (King of Sweden) happened to pass nigh the barrow of Asvid, and the Swedes thinking it might contain treasure, broke into it with mattocks, and saw disclosed a cave deeper than they had anticipated. To explore this, a youth, chosen by lot, was let down in a basket. But Asmund, when he saw the boy descend, cast him out, and got into it himself. Then he gave the signal to draw up. Those above drew in the basket, thinking by the weight that it contained much treasure. But when they saw the unknown figure of a man emerge, scared by his strange appearance, and thinking that the dead had come to life again, they flung down the rope and fled. For Asmund looked ghastly, covered with the corruption of the charnelhouse. He tried to recall them, and assured them that they were needlessly alarmed. And when Eric saw him, he marvelled at the aspect of his bloody face, the blood flowing freely and spurting out. Then Asmund told his story. He had been buried with his friend Asvid, but Asvid came to life again every night, and being ravenously hungry, fell on and devoured his horse. That eaten, he had treated his $\operatorname{dog}$ in the same manner, and having consumed that he turned on his friend, and with his sharp nails tore his cheek and ripped off one of his ears. Asmund, who had no ambition to be eaten, made a desperate resistance, and finally succeeded in driving a stake through the body of the vampire. Out of delicacy due to old friendship, Asmund did not have recourse to the usual means of quelling the posthumous vivacity and vitality of a corpse, which was to cut off the head and make the dead man sit on it. ${ }^{1}$

The notion of suspended animation after death by no means expired with paganism. When Severus, Bishop of Ravenna, was about to die, he went in full pontificals to the tomb of his wife and daughter, had the stone removed,

\section{1 "Saxo Gramm.," V., chap. clxii-iii.}




\section{ROCK SEPULCHRES}

and bade the dead ones make room for him between them, and they obeyed. When S. Meven died, and his faithful friend Austell followed him shortly after, the dead body moved on one side in the sarcophagus to accommodate his companion. When an irreverent man struck the coffin of S. Cadoc with a staff, the incensed Saint "roared like a bull." In the Life of S. Germanus of Auxerre is a curious episode. A pagan named Mamertinus being overtaken by night and a storm, took refuge in a solitary building in which was a sarcophagus. He put his knapsack under his head on the upper slab of the tomb, and lying down there went to sleep. At midnight he was roused by a young man at the door of the cell, who called out, "Corcodemus, Corcodemus, levite of Christ, arise!"whereupon a voice answered from the tomb, "What do you want?" The youth replied, "Bishop Perigrinus and Bishop Amator want you at the church, where they are holding vigil." "I can't go," replied the dead man, "I have a visitor here and I must show him hospitality." After an interval the young man returned with two others and again summoned Corcodemus, who now got out of his grave and said to one of those who was at the door, "I will go with you, but you must abide here and protect my visitor, for there is a bitch with her young, to the number of seven, ready to tear him to pieces."

So late as 1680 a book appeared, De Miraculis Mortuorum, by L. C. F. Garmann, published at Leipzig, opposing opinions not merely of the ignorant but of the learned as to a kind of prolongation of physical life in the deadtheir issuing from the graves to suck the blood of the living, their continuing their wonted avocations underground, as a shoemaker being heard cobbling in his coffin, of infants shedding their milk teeth and growing second teeth, of gnawing their grave clothes, and many other horrible superstitions-showing how persistent the 307 


\section{ROCK SEPULCHRES}

belief was that the dead did continue to live in their sepulchres. ${ }^{1}$

The idea that by symbolic burial a man became regenerate, that he put off the old condition and entered into another that was new, by passing through the earth or a hole in the rocks, was very general, and it has continued to the present day in the modified form of enabling a sufferer by this means to leave behind his infirmities and pass into a condition of robust health, or of one charged with a crime clearing himself by this ordeal.

The passing of a child through the earth was forbidden by the Canons of Edgar (A.D. 969). ${ }^{2}$ Women who had crying children dug a hole in the earth and thrust the child through, drawing it out at a further hole. Men were forbidden also to pass cattle through a hollow tree or per terram foratam transire. In France weak children were passed through a hollow stone of S. Tessé. In the crypt of Ripon Minster is a hole in the rock through which young women crept to establish their innocence when charged with incontinence. In Iceland a long turf was cut attached to the soil at both ends, and such as would pass out of a condition of hostility into one of brotherhood crawled through the gap. At Ilefeld, in the Harz, is a holed stone called the Nadelöhr. Any one coming to settle in the Harz for the first time is required to creep twice through the perforation. In a good many places in Germany a similar process is gone through to cure lumbago. Indra, the god

1 The confusion between the ghost and the corpse is exemplified in " Hamlet."

"Tell

Why thy canoniz'd bones, hearsed in death,

Have burst their cerements ; why the sepulchre,

Wherein we saw thee quietly inurn'd,

Hath op'd his ponderous and marble jaws

To cast thee up again."

Act i. sc. 5 .

2 Thorpe, "Ancient Laws and Institutes," Lond. 1840.

308 


\section{ROCK SEPULCHRES}

of Thunder among the Hindoos, drew a sick man thrice through a hole, and thereby gave him health and new birth. The many Helfensteins that are found in Germany were in like manner stones of Help, by traversing which the old man was put off and the new man put on. ${ }^{1}$ Creeping through a holed stone, or under one suspended over another, is still practised in Ireland as a cure for disorders. From passing under the earth the custom passed to going through a split tree, the tree representing the coffin. An interesting account of this usage will be found in White's "Selborne."

And now let us turn to something else.

A religion of the worship of ancestors formed the ground-work of many religions that in process of time have totally changed their character. It lies at the root of the creeds and practices of most peoples in east and west. It was in Greece before its religion passed into the stage of the deification of natural forces. The Assyrians and Chaldeans clung to it in Western Asia. The Egyptians in the valley of the Nile, the Etruscans in Italy. At the other extremity of the world, the Chinese and Anamites perform its rites to this day from Saghalien to Cambodia.

But in Western Asia and in Europe the primitive religion became modified little by little. On the borders of the Tigris and the Euphrates, as well as on the banks of the Nile, appeared the beginnings of a different eschatology and a vague expectation of a resurrection of the dead. The Hellenes and Romans, under the influence of philosophy, acquired another conception of immortality, and their institutions, issuing from collectivism, broke up into individualism.

In the extreme East, on the other hand, the ancient beliefs and institutions remained stationary, and Buddhism was unable materially to disturb them. It introduced its doctrine of Metampsichosis, its Nirvana, and its hell ; but

${ }^{1}$ Sepp, Altbayerischer Sagenschats, Munich, 1876, p. 87 et seq. 309 


\section{ROCK SEPULCHRES}

these notions did not modify, they got mixed up with the old conceptions in a jumble of heterogeneous and contradictory beliefs. To the present day the family remains the unit in the State; it is under the patriarchal despotism of the head of the line, the priest of the domestic hearth, the proprietor for the time being of the family estate. Every household has its particular gods and protectors-the ancestors thus sublimated, and the master of the family, the prospective god. The condition beyond the grave in no way depends on conduct during life, it is determined by the descendants. If the defunct be honoured, enriched with sacrifices, he becomes a beneficent protector and is happy; neglected and abandoned, he avenges his unfortunate condition on his forgetful posterity. To transmit the family cult and the patrimonial field to an heir is the first duty of man. We inherit unconsciously, not the physical character of our ancestors only, but also their ideas and prejudices. Our practices are often dictated by custom of very ancient date, not at all by reason or by conviction. Expense and trouble are incurred to convey a corpse from one end of Europe to England, that it may repose in the family vault. We decorate our graves with flowers as though the dead appreciated them; they are but the representatives of the ancient sacrifice to the dead. We drink to the memory of the deceased as though pouring out libations to them. Our tombstones are direct descendants of the menhir and the obelisk, our altar-tombs of the dolmen, our family vault of the primeval cave ossuary.

But in one point we have diverged very far from the path of old beliefs. We have lost touch with the invisible world; we put our dead out of sight and remember them no more, as though no part of the community to which we belong, nor links in a chain of which every link is living.

It was one of the sayings of Swedenborg, that the Aryan West had something to learn from the 'Turanian East. It 


\section{ROCK SEPULCHRES}

is so-the reverend thought of the dead as still forming a part of the organism of the family. With the revolt at the Reformation at the trade made out of the feelings of the bereaved, the coining of their tears into cash to line the pockets of the priests, came an unwarranted oblivion of the dead, a dissociation from them. The thought that the departed had still a claim on our sympathy and on our prayers was banished as smacking of the discarded abuse. Prayer for the dying was legitimate and obligatory at ten minutes to three, but prohibited at five minutes to three when the breath had passed away. We have gone too far in this direction. We live in an immaterial as well as in a material world. We are planted at the overlap of two spheres, that which is spiritual and that which is physical, and we gravitate so sensibly and so rapidly to the latter as to lose touch with the former, and finally to disbelieve in the existence of such a sphere.

The earth can radiate its heat, and receive and be steeped in the falling dew only when the sky is not overcast; but our hearens are so thick with clouds that our spirits can exhale no warmth into the Infinite, nor drink in any balm descending from the Unseen. It is only by detachment from the routine of vulgar life that we can enter into any relation with the spiritual world. Political interests, social obligations, financial concerns, choke the spiracles of our inner being, and we lose all concern about what is supersensible, and hold no communication with it. There are stars and planets overhead, Orion with his spangled belt, Cassiopeia in her glittering chair, and Pleiades in their web of silver, but we cannot see them because of the fog that envelops us.

According to an Indian legend, the first men were bred like maggots in the heart of the earth, but laying hold of some depending fibres drew themselves up into the light of day. We reverse the order, and from the bright spiritual 


\section{ROCK SEPULCHRES}

sphere crawl underground by the thousand tendrils of daily life.

The early Methodists and the Quakers broke away from the low material conception of life common in their day, and asserted the reality of the spiritual world, and the duty of living for it, as also the certainty of holding intercommunion with the spirits. 'The 'Other worldliness' of the mediæval monastic mysticism had produced a revolt against a conception of life that was false, its passive hostility to civilisation, the hollowness of its ideal existence, its exaggerated asceticism, its disparagement of the family life, and the result was the swing of the pendulum in the opposite direction. The recoil came with the Methodists. But we cannot live wholly in the world of spirit, any more than we ought to live wholly in the world of matter, for our nature is double, and no portion of it should be atrophied. Extreme mysticism is as falsifying of our nature as is extreme worldliness. The stupidity and charlatanism of modern spiritualism is the rebellion of men and women against the materialism of present conception of life. Where natural expression of a need is checked, it breaks out in a disordered form, just as arrested perspiration and circulation of the blood produce fever. If all recognition of supersensible existence be denied, the assertion that it does, has its place, and makes its demands on us, will call forth, if not a wholesome, then a diseased expression.

We are intended to rise at times and breathe the atmosphere above us, and then to descend again to the lower region. It is only the dab and the common plaice that are content to lie ever on the bottom, and they are but onesided fish. 'They see with one eye only, the other' has been absorbed and become dead. Every creature has in it a promise of something better than what it is. The slowworm has rudimentary legs, but they are never developed; 


\section{ROCK SEPULCHRES}

the oyster has rudimentary eyes, but they come to nothing. The larva has in it the promise of wings, and it grows into a butterfly or dies a grub. The soul of man has its wings so battered by its cage and is so enamoured of its groundsel and bit of sugar, that even if the door be left open it will not look forth, certainly not break away. Yet there is a world beyond the bars, and a world peopled by happy spirits, and if it cannot at once join them, it can call to them and unite with them in rapturous song. The old turnspit was bred in the kitchen, and its daily task was to run in the revolving drum that helped to roast the meat. Its legs became deformed like those of the dachshund. It cared not to romp in the green meadows, to run with the hounds, it waddled about the kitchen floor looking out for the bones and scraps of fat cast to it, as payment for its toil. And that is what we are becoming through unremitting neglect of our spiritual avocation.

More than fifty years ago I was walking at night through lanes near Dartmoor, and caught up a trudging postman who daily, nightly, measured long distances. I soon found that he was a man who had his spiritual eye open.

"Do you not feel lonely in these long walks in the dark?" I inquired.

"I am never alone," he replied, "the spirits are always with me."

"Your thoughts," I suggested.

"My thoughts are indeed within me, humming in my head. I must go forth to meet the spirits. Look here," he went on, "the soul of man is like a fly in a cobweb. It can't spread its wings till it breaks loose, and then it very often carries away some of the threads with it."

Mr. Jacks gives us, in his "Human Studies," one of a shepherd on the Wolds, the counterpart of my postman. There be more of these men than is generally supposed. But he who would deal with this subject would be con313 


\section{ROCK SEPULCHRES}

strained to say with the knight in the "Canterbury Pilgrims"-

"I have, God wot, a large field to ere

And wayke ben the oxen in the plough."

I have broken away from my caves, and have rambled-I know not whither.

Vive, vale : si quid novisti rectius istis,

Candidus imperti; si non, his utere mecum.

-Horace, Epist. i. 6. 


\section{A P P E N D I X}

Owing to the great kindness of Mr. Wm. Stevenson, author of "Bygone Nottinghamshire," I am able to give some additional matter that must be of interest, with which he has supplied me.

(p. 32.) "Your account reminds me of a rock excavation of great extent with turns and windings on the old time 'Way to the Gallows,' in Nottingham, where a number of cave-dwellings existed down to a century ago. The last tenant was a sandman who stabled his ass in the cave behind. He passed the greater part of his life in selling sand about the town, carrying it in a sack across the back of his ass. Time wore him out, and he had to enter the workhouse. His cave was then explored, and it was found of enormous extent, in two storeys. It is supposed to have been mainly wrought day after day and year after year by this sandman. It is still to be seen, but dangerous to explore. One party of investigators a few years ago carried a string with them as a clue by means of which to find their way out again. There is a story of it becoming a lurking place of robbers after the sandman's day. A number of the excavations under the town are held to have been made or extended by the tenants above, obtaining their supply of sand from below. Formerly floors were sanded."

(p. 35.) Puticoli. Slave pits have been found in South Africa. "When the old town hall and town prison at Nottingham was demolished a few years ago, and the site was excavated for the advance of the Great Central Railway, seven or more pits were found, one with a rusty chain in it. They were about four feet in diameter at the top, and seven feet at the bottom, with dished floors. They varied from about twelve to eighteen feet in depth. We had no knowledge of anything of the kind in local history. Two others were found a distance away that could have had no connection with the prison site." 315 


\section{APPENDIX}

Formerly at Monte Carlo the bodies of suicides were thrust into the holes that riddle the limestone rock and gave it the name of Les Spelunges. But the conditions became insanitary, and Italian workmen were employed to get them out, and carry them away to sea and there sink them.

(p. 50.) "Formerly it was the way in which wells were ascended and descended in Nottingham, by means of notches cut in the side for the insertion of toes and fingers. I have had to do with the exploration of the base of Edward IV.'s Tower at Nottingham Castle, destroyed with gunpowder during the Civil War. In one corner of the basement we found a well filled with rubbish. This the workmen cleared out for over fifty feet, and all the way down were notches in the wall, and the men went up and down like monkeys, using no other means for ascending and descending."

(p. 83.) Ventholes for smoke were common in Nottingham, Sneinton, and Mansfield.

(p. 82.) Souterrains. Mr. Stevenson writes relative to the pits before the entrance doors of refuges: "Some years ago I had a part in exploring the Norman Keep of Scarborough Castle, erected early in the reign of Henry II.; we worked under the entrance staircase, and found a pit arched over at a later period and covered with a stone landing, but originally it must have been a pit or well in front of the only entrance door. It was partly cleared out of fallen masonry and rubbish, but not properly explored. Overhead was a shoot for stones or molten lead. It would appear that the pit system was abandoned about the close of the Middle Ages."

(p. 98.) "It is fairly well determined in the "History of Nottingham' that the Roman Catholics in Elizabeth's and James I.'s reign met secretly in the caves in the rock of the town. They were also refuges of the Dissenters in the days of Charles 1I."

(p. 153.) Nottingham. "There have been several falls of the rock, both at Nottingham itself and at Sneinton. Mortimer's Hole, under the Castle, is only one of four that are known to exist, three of which ean be traversed, one wholly and two in part; one of these latter is by many regarded as the true 316 


\section{APPENDIX}

historical passage. It started at the meadow level, and was partially closed by a wall; the rock wasted with time, and the thin wall gave way, bringing down a vast amount of rock above, and leaving the cavern in this part an open alley. The cave was then converted into malt offices, which yet remain in the higher and perfect part. The rock-caverns in the park, the old cell of S. Mary-le-rocke, formed possibly the parent of Lenton priory, just as those at Ligugé were the parent of the abbey on the further side of the river. The rock monastery, the 'Papists' Holes,' has long ago lost most of its front by falls of rock and the destruction wrought by the Roundheads. A huge artificial pillar has of recent years been erected to prevent further falls. A fall in 1829 brought down from 1000 to 1400 tons, a mass some seven or eight feet thick. On 10th May in the same year, evidently due to an earth tremor, a like great fall occurred at the rock habitations at Sneinton. The inhabitants escaped as by a miracle. A dog barked furiously in the night, and the inhabitants of the cave dwellings rushed forth, fancying that robbers were at work there. In 1830 a portion of the town cliff fell, as did also some of that in the park.

"The county or sheriff prison for Notts and Derby was, as far as can be traced back by records, half-way up the over ninety feet cliff of the town of Nottingham, and was entered from the King's hall at the top. Light holes were made in the face of the rock to the south. In these vaults, now closed, men and women were confined like wild beasts, on straw. The prior and monks were enclosed here in the time of Henry VIII., and were marched thence to the gallows. The inhabitants of the lower part of the town under the prison complained of the ordure exuding from the prison and trickling down the rock. There are records of marvellous escapes of prisoners, both male and female, down the face of the rock, till comparatively recently. As may well be supposed, gaol-fever raged in these horrible dens. One vault is still shown under the castle. Leland and Camden both speak of an underground dungeon in which tradition (this time falsely) says that King David of Scotland was confined, and on the walls of which with a nail be 317 


\section{APPENDIX}

carved a crucifix. These travellers do not say that they actually saw it; but Thomas Bailey, in publishing his 'Annals of Notts,' employed a local artist to depict the scene. After the erection in the seventeenth century of the Italian castle, the vault was converted into a wine-cellar. Leland says that there had been three chapels in the castle, but he does not say where.

"In the town of Nottingham are two rock-hewn stairs. The most important is called the 'Long Stairs,' they begin, cut out of the perpendicular face of the rock, at its highest point, landing opposite the old mother church. The steps are now faced with harder material than the local sandstone. On the side there are louses, and indeed houses on the tops of houses, a tenant at a lower level, another at a higher, each obtaining entry from the stairs. The 'Short Stairs' are not wrought in the face of the cliff, and have houses on both sides. These are clearly in a prehistoric quarter of the town, where was onee a hill-fort."

(p. 159.) Ford Castles. The ancient ford at Retford, Notts, was more north than the present, and beside it is a red cliff largely cut into with joist-holes, \&c., for floors and roofs, and give inclications of former habitations.

Radford, a name borrowed by the priory, alias Worksop, is a hill of red sandstone that dominated the ford. On the hill is an entrenchment.

(p. 160.) Mr. Stevenson remarks on the holes in the floor at Rochebrune; "This is what I should expect to find in a maltery, which must be of two floors, the lower one for steeping and sprouting the corn, and holding the fire-crates, the higher one for drying and storing the malt. The higher floors are now made of perforated tiles, the holes too small for the grains to pass through, but in old times I think the malt was dried in braziers something like large frying-pans. Drying rooms for wheat were attached to corn-mills to dry the corn before grinding. In some seasons corn is difficult to dry; perhaps in France they did not make malt, but they may have dried grapes." Malt was not made in Perigord, I believe; and the indications at Rochebrune are strongly those of defence against assailants. Grapes would hardly be dried in a cavern, but in the sun, and there is plenty of sun in the South of France. 


\section{N D E X}

ABBADIE, 238

Acharaca, 250

Adersbach, 70-71, 291

Adullam, 277-278

Afghanistan, 6

Agapæ, 201

Agel, Mont, 171

Aigner, Lazarus, 259-261

Alban, 78

Albigenses, 7T, 113, 124

Albret, the Bastard of, 127, 129, 134. 136

,' Jeanne d', 162, 187

Algeria, 102

Altamira, 25

Altars of wood, 176

Amadou, care of S., 214-215

Amator, S., 188

Anaplous, 266

Ancestor worship, 175, 309

Anchor Church, 223

Anchorites, 204-205. See also Hermits Anglais, Châtean des, 136-137, 141

Angoulême, 65, 206

Antinoe, 193

Antoine de Bourbon, 162, 187

Antony the Great, 228

of Padua, 212 213

Apollonios of Trana, 250

Aquitania, 75- $76,95,106,119,159$

Arabia Petræa, 21

Aram, Engene, 221

Arc, Jeanne d', 128

Archerfield, 98

Arian persecution, 229, See also Visigoths

Armenia, 6

Arsinoë, 229

Arthur, King, 259

Asmund and Asvid, 305-306

Athanasius, S., 203, 231

Auberge du Paradis, 23, 132

Aubeterre, 78, 184-187

Austell, S., 307
Austin's Rock, Holy, 59

Auvergne, 112, 129, 143-146

BABIYSKY, 292-293

Balmes du Montbrun, 51

Bamian, caves of, 6

Baptistery, 234, 235-236

Baradatus, 204

Basilican churches, 173-174, 176$1 \% 7$

Basket makers, 47

Bauer, the German, 20

Beatus, S., 206

Beaumont-la-Ronce, 40

Benedict, S., 218

Beræa, 204

Besançon, 171

Besserat, Bertrand de, 136

Bethhoron, 72

Bethlehem, 193-194

Beune River, 47

Bigaroque, 133

Bishops, Gallo-Roman, 205, 233

Blancs, les, 45-46

Blandas, grotto, 28

Boissière, 51

Bonnaventure, Château, 162

Borne River, 52-53, 152

Bottor rocks, 116

Boundoulaou care, 109

Bourg-sur-Garonne, 78

Bourré, 46

Boydan, Châtean, 36

Brantôme, 48-49, 167, 195, 238-239

Brengues, cliff castles, 110, 135-136

Bretigny, Treaty of, 77, 119

Brice, S., 236-237

Brittany, 88-89, 189-192

Brive, 111, 212-213

Backland, Dr., 21

Buddhism,'196-198, 199, 201- 204, 309

Burgstein, 153-154

Buxton cave, 114

Byzantium, 266 


\section{INDEX}

Cabrenets, 134, 136

Cadoc, S., 307

Caerleon, 267

Caer Penselcoit, 20

Cahors, 133, 135-137

Cajarc, 133-134

Calvin, 164-165

Calvinism, see Huguenots

Cann, John, 116

Canope, 205

Capdenac, 133

Carlux, 129

Carmel, Mount, 195

Catacombs, 173-174, 296-299

$$
\text { " } \quad \text { Jewish, 296 }
$$

Catacumbal churches, 173, 176

Caudon, 129, 189

Causse de Quercy, 128-131, 134, 281

Cazelles, 104

Célé River, 28, 48, 110, 133, 135-137

Ceyssac, 53

Chalk, 17-20, 23, 26, 97, 146, 162-163, 167,302

Champagne, 26

Charente River, 163

Charonion, 247, 268

Château des Anglais, 136-137, 141 " du Diable, 134, 136-137, 141

, de Fayrolle, 83-84

" Robin, 78-82

Chauvigny, 160

Cheney, Sir Robert, 125

Chinamen, 277

Chislehurst caves, 95-97

Christchurch, Incubation at, 267

Chysoyster, 20

Citheron, 257

Civilis, 72-73

Cluseau, 56

Commarques, 55

Companies, Free, 55, 106, 123, 125$128,129,131,133$. See also Routiers

Conduché, 28, 133, 137

Confolens, Dolmen at, 192

Conrad, Friar, 249

Conscription, 89-90

Conteaux, 52

Contigne, 87

Corbulo, 72

Corcodemus, 307

Cordova, 218

Corent, 112

Corn, 133-135
Cornwall, 60-61, 67, 98, 221-222

Corrèze, 54-56

Cosmas and Damian, SS., 266

Courtineau, 47

Covolo, 155

Crassus, 72

Crete, 101-102, 192-193, 246-248

Crimea, 50-51, 245

Crouzate, la, cave, 280-281

Crusaders, 195

Crypts, 174, 184, 189, 195

Cuzorn, 48

Cybard, S., 206

DALE abbey, 60

Darenth wood, 95

Dartmoor, 253, 313

David, 277

Death, goddess of, 302

Défilé des Anglais, 48, 137

Delos, 277

Delphi, 247

"De Miraculis Mortuorum," 307

Dene holes, 95-97

Derbyshire, 59-60, 114-115

Der-el-Adra, 249

Devil's Dyke, 66

Devonshire, 66

Dolmen chapels, 189-192

Dordogne River, 7, 104, 129, 149, 151, 181

Dover, 172, 226

Drakelow, 59

Dronne River, 167, 184

Duclair, 43

Dunterton, 284

Écorcheuns, 44

Edmund, S., of Canterbury, 205

Edrei, 30

Egg, Isle of, 99-100

Egypt, 51, 193, 199, 229, 244, 295

Egyptian sepulchres, 295

Ehrenbreitstein, 171

Emilion, S., 181-184

Essenes, 199

Esterelle, 240

Eyzies, les, 22-23, 24, 118

Ezy, 40-43

Fadarelles, Grottoes de, 110-111

Faron, 171 


\section{INDEX}

Fauroux, 84-85

Fayrolle, Château de, 83

Ferrage, Jules, 281-282

Feruiden, 280

Fetzer, 207-208

Feudal barbarity, 87, 93-95, 119, 125, $143-144,146$

Figeac, 133

dnties, 86,117

Findchua, S., 204-205

Fogous, 98

Francis, S., 218-219

Frederick Barbarossa, 259

Freiburg, 211

Froissart, 93, 125, 126-127, 170

\section{GAPENwES, 90-91}

Gargas, cave of, 281-282

Gatianus, S., 234-235

Gauderic, S., 84

Gest, 203-204

Gethsemane, 193-194

Gibraltar, 171

Glass windows, 180

Gluges, 181

Gorlitz, 195

Gortina, 101

Grammat, 131, 152

Grands Jours, les, 144-145

Greenhithe, 226

Grettir, 283-284, 303

Grioteanx, 47

Grotte de Jioux, 161

,, Jouclas, 189

", des Fées, 189

,, ,, Vierges, 37

Grottoes de Boissière, 31

", "Jonas, 52

Gubbins, the, 66

Gué du Loir, 162-163

Gunnar, 305

Gurat, 189

HABICHSTEIN, 152-153

Hallbjörn, 252-253

Ham, 63

Han, 28-29

Hasting, 76

Hauran, 30

Hautefaye, 49

Hawkwood, 125

Helfenstein, 209

Helgi Hundingsbane, 305
Hermits in Bohemia, 154

,, , Egypt, 198-199, 228-229, 231

, ,, England, 220-221, 225227

", ,, France, 205-206, 214-215

", , Germany, 207-208

, , Ital5, 218-219

, , Languedoc, 206-207

,, ," Switzerland, 206, 208-211

", ", Syria, 198-199, 228-229

," " Tibet, 196-198

Herodotus, 30

Hervör, 302-303

Holy Austin's Rock, 59

Holy Land, grottoes in, 193-195

Honoratus, S., 240

Horseflesh, 27

Hnguenots, 112-113, 135, 139, 148, $150-151,166-167,189,233,234$

Hundred Years' War, 77, 105, 123, 150,184

ICELAXD, 95, 252-253, 282-284

Immortality, instinct of, 301-304

Incubation, 240, 264-267

Indulgences, 217,257

Ingrandes, 78

Inkermann, 51, 245

Ispica, Val d', 49-51

Italy, disorders in, 120

", hermitages in, 218

Jioux, Grotte de, 161

John and Paul, SS., 175

Jonas, Grottoes de, 52

Jordas cave, 116

Jouclas, Grotte de, 189

Julins Sabinus, 73-74

Jura limestone, 18, 149, 154

KLiver, 59

Knaresborough, 220-221

Knollys, Sir Robert, 125

Königstein, 172

Kronmetz, 155

Kynaston, Humphrey, 269-276

LALANDE, 151

Lamorcière, General, 102 


\section{INDEX}

Lamouroux, Grottoes de, 56

Landon, Mr., 196-197

Lanmeur, 189

Lartet and Christy, 22, 28

Larzac, Causse de, 109

Laugerie Basse, 27

Lavardin, 37, 80

La Vendée, 88-89

Lavergue, 131

Lazarus Aigner, 259-261

Leichtweiss, 289-291

Leitomischl, 294

Leobard, S., 237

Les Fyzies, 22-24

Les Roches, 35-36

Lhern, 131

Ligugé, 233-234

Lirac, 188

Lisle, 39

Loir River, 32, 35, 162, 214

Loire River, 32, 43, 76, 234

Lombrive, cave of, 77, 114, 279

Lot River, 7, 75, 129, 133

Loudun, 40

Lough Derg, 254-259

Lourdes, 267-268

Lyall, Sir Charles, 21-22

Lydford, 66

Lyons, 201

MACAIRE, Saint, 78

Macarius, S., 202

Macdonalds, massacre of, 99

Mad shepherds, 68-69, 313

Makkedah, 72, 278

Mansfield, 58

Manteion, 247-248

Marmoutier, 234-237

Martin, S., 231-237

Mary Magdalen, 213-214

" of Egypt, 228

Masch, Karl F., 285-289

Maskers, 235

Maximus, S., 239-240

Mas d'Azil, 26]

Mées, Les, 110

Melidoni, 101

Mellebaudes, 178-180

Melor, S., 189-190

Mercader, 33

Meschers, Grottoes de, 112

Meteora, 242-243

Meullac, 89

Middle Castle, 270-271
Milan, 109

Mimet, 188

Misdon, 88

Montserrat, 215-217

Mont Agel, 171

Montoire, 31, 35, 37

Montvalon, 86-87

Mortimer, 157-159

Moustier-Ste-Marie, 240

Murat, 87

Murcens, 107

NAHE River, 211

Naours, 91

Naples, 298

Napoleon, 89

Navacelles, 28

Ness Cliff, 271-272, 276

Northmen, 92, 147, 234, 302

Nottingham, 76, 157-159, 227-233, $234,241-242,315-318$

OBERSTEIN, 211-212

Olmie, 86

Oracles, 246-252

Orvar Odd, 76, 95

Paintings, prehistoric, 24-26, 295?

Palestine, 6, 71-72, 193-195, 277-279, 295-296

Palevez, 133

Pappewick, 222-223

Passing under the earth, 308

Paulin, 87

Pausanius, 248-2500

Petit Morin, 302

Peuch S. Sour, 105-106

Peyre, 188

Peyrousse, 137-139

Philo Judæus, 199-201

Picardy, 90-93

Pit dwellings, 20

Plouaret, 190-192

Plutarch, 250

Poitiers, 144, 178-190, 232

Polignac, 246

Popish Holes, 241-242, 317

Porphyry, 246

Potters, 240

Pueblos, 5-6

Puit qui parle, le, 35

Purgatory of S. Patrick, 254-257 


\section{INDEX}

Poticoli, 35, 298, 315

Pay Labrousse, 111

Puxerloch, 155-157

QUERCY, 75-76, 85-86, 129, 130-131, 151,188

\section{RADFORD, 318}

Rathlin Island, 100-101

Reign of Terror, 114

Relics, $176-177$

Reneral, 92

Repton, 223

Retford, 318

Revolution, the French, 212, 233, 234, 236, 238, 300-301

Ribauds, 125, 126, 132, 148, sce also Routiers

Riou Ferrand, 109

Robber knights in Germany, 120

Robert, S., of Knaresborough, 220-221

Robin Hood's Cave, 222

Rocamadour, 188-189

Roc d'Aucor, 106-10s

, de Cuze, $15 i$

, de Tajac, 24, 132-133, 148

Rochambeau, $37-38$

Rocbe, 221-222

Roche Beaucourt, 49

Rocbebrune, $167-170,318$

Roche Corail, 163-167

" de Corbon, 39

" Gageac, 149-151

, Lambert, 152

", Saint Christophe, 133, 146-148

,, Sanadoire, 140-141

Roches, les, 35-36

Roderic, King, 261-262

Roquefort, 135

Roqueville, 152

Routiers, 108, 113, 119, 121, 123-124, $128,137,140-141,142-143$, see also Ribauds and Companies, Free

Royston care, 224-227

SABINCS, Julius, 72-74

Sainte Beaume, la, 213-214

Salles-la-Source, 87

Sanadoire, 140

Sandstone, $54-56,70-71,84,142-143$, $183,212-213,271$

Santerre, 91
Saracens, $74-75,85-86,114,180,233$, 243

Sarlat, 129, 149-150

Saul, King, 252, 253

Sauliac, 48

Saumur, 43-45

Scoop wells, 53

Scotland, 61-64, 98, 280-281

Sens, 68

Serapion, 229

Seven Sleepers, 190, 236

Severus, B. of Ravenna, 306

Shepston, 110

Sibyls, 251-252

Sicarius, S., 195, 239

Sicily, 45-50, 298-299

Siourat grottoes, 56

Sneynton, 59, 316

Sortes Sacræ, 233, 262-264

Sonillac, 189

Soulier-de-Chasteanx, 111-112

Sour, S., 105

Spain, hermitages in, 208-211

Springs in crypts, 195

Staffordshire, 59

Subiaco, 218

Sulpice, S., 87

Surtshellir, 279-280

Swedenborg, 310

Swiss bermitages, 208-211

Syracuse, 298-299

TABENXA, 229

Tannhäuser, 259

Tarde, Jean, 149-151

Tarn, gorges of 41

Tayac, Roc de, 132-133, 178

Temniac, 129, 133

Terni, 253

Therapeutæ, 199-200, 252

Theresa, S., 198

Thomas à Becket, 205

Thor's Care, 115

Tibet. 106-108

Tilbury Dene Holes, 97

Toledo, 261

Tombs for aitars, 175-176

Tours, 233-237

Trèves, 231

Triumph of death, 238

Trôo, 32-35, 214

Trophonios, cave of, 248-250

Trosky, 139-140

Tursac, 133 


\section{INDEX}

URDOS, 171

Utraquists, 140

VAL d'Ispica, 49

Var, 213

Vendôme, 37, 86, 162, 214

Verena, S., 210

François de, 38-39

Vernia, La, 218

Vers River, 106, 109

Vézère River, 22, 27, 47, 105, 111, 146

Victor Hugo, 88-89

Vienne, dep. 88

Villaines, 47
Villiers, 7, 214

Visigoths, 114, 159-160, 180

Voulon, 114, 161

WARKWORTH, 219, 220

Welsh marriages, 273

Wick, Bay of, 61-64

Wickelsdorf, 70-71, 291

Wiesbaden, 289-291

Wild Kirchlein, 208-209

Wulfric, S., 205

Würzburg, 195

ZACCHEUS, 188

THE END

Printed by Ballantyne, hanson $\&$ Co.

Edinburgh \& London 


\title{
THE NEW ART LIBRARY
}

EDITED BY

\author{
M. H. SPIELMANN, F.S.A., and P. G. KONODY \\ "The admirable New Art Library."-Connoissexr
}

T

1HE volumes in this series are primarily intended for the use of Art Students. The instruction given is of the most thorough kind, and is based on long practical experience and intimate knowledge; the names of the authors will be a sufficient guarantee for the high excellence of their work. The greatest care is being bestowed on the illustrations, which are very numerous and in a remarkable degree explanatory of the text. It may be doubted whether artistic processes have ever before been so clearly illustrated.

It is hoped that the volumes will also be welcomed by those amateur artists who, although they do not follow art for a livelihood, are in no way content with inferior craftsmanship, but are earnestly bent on acquiring a sound and workmanlike method, based upon knowledge of technical processes in all their details.

But there is a third class to whom these volumes may prove of high interest, the lovers of art, who, though they produce nothing themselves, are not content with an unintelligent enjoyment of artistic creations. No one can be said to understand them who is ignorant of the principles on which they are executed. The special enjoyment which an artist finds in a work of art may be shared by the art-lover if he will take the pains to examine it in the same way as the professional artist, and thus gain some understanding of the purely technical means of expression employed. The cultivation of a correct taste is thus assured-the knowledge not only of what to like, but why to like it. Appreciation is thus founded on reason.

The prices of the volumes will be lower than those of any similar publications; at the same time, the publishers believe the series will be as complete, thorough, and practical as any hitherto issued, and will contain many novel features not hitherto found in kindred works. The intention has been to meet the requirements of students and of Art Schools throughout the country, who will at length be able to procure trustworthy and authoritative instruction books at a modest expenditure.

\section{VOL. I.}

\section{The Practice of Oil Painting \& Drawing} By SOLOMON J. SOLOMON, R.A.

With so Illustrations from Mr. Solomen's Drawings and ofher sources. Extra crosen 85o. 6s. not

\footnotetext{
" The work of an accomplished painter and experienced teacher."-Scotsman.
}

"If students were to follow his instructions, and, stil] more, to heed his warnings, their painting would soon show a great increase in effciency." - Maschester Guardiax.

"The drilling that yon get at the cost of many fees in an art school is all to be found at a single sitting in this book." -Illastrated Londos News.

LONDON : SEELEY \& CO. LIMITED. 38 GREAT RUSSELL STREET, W.C. 


\section{VOL. II. \\ Human Anatomy for Art Students}

BY

SIR ALFRED D. FRIPP, K.C.V.O., C.B., M.B., M.S.(Lond.), F.R.C.S.

Surgeon-in-Ordinary to H.M. the King; Lecturer upon Anatomy at Gny's Hospital, London AND

RALPH THOMPSON, M.B., Ch.M., F.R.C.S. (Eng.)

Senior Demonstrator of Anatomy, Guy's Hospital

And an Appendix on Comparative Anatomy, and Illustrations, by HARRY DIXON, M.S.B.S.

Profusely Illustrated with Photographs, and by Drawings by

INNES FRIPP, A.R.C.A.

Master of Life Class, City Guilds Art School

With 151 Illustrations. Square extra croten 8vo. 7s. 6d. net

"An ideal manual for the student of the most difficult and most easential branch of art stady."

Liverpool Daily Post.

" This book, with its abundant and excellent illustrations, will be a real help to knowledge."

Pall Mall Gazette.

"Excellently illustrated from the first page to the last by original drawings and photographa most carefully taken."-Westminster Gazette.

"Combines the best acientific and artistic information."-Connoisseur.

"A book which we can unhesitatingly recommend to the art student, because it is written by men who are thoroughly at home in the subject treated of, and wbo, moreover, have been mindful not to encumber their exposition with unnecessary minutiæ." -Studio.

\section{VOL. III. \\ Modelling and Sculpture}

BY

ALBERT TOFT, A.R.C.A., M.S.B.S.

Profusely Illustrated with Photographs and Drawings

Square extra crown 8vo., 6s. not. With 119 Illustrations

"The details are very clearly set out, and the instruction throughont is of a thoronghly practical kind."-Nottingham Guardian.

"A model of clearness. A book that should be found most attractive to all art lovers, as well as invaluable to atudents of the processes described therein." -School Guardian.

"Will be exceedingly useful and even indispensable to all who wish to learn the art of aculpture in its many branches. The book will also appeal to those who have no intention of learning the art, but wish to know something about it. Mr. Toft writes very clearly." - Field.

"Written in a most interesting manner, beautifully printed on excellent paper, and illustrated as Messrs. Seeley know how to illustrate."-Glasgow Citizen.

"Will be found an invaluable aid to the student. ... Takes the student step by step through the various technical processes, the text being supplemented by over a hundred excellent illustrations." - Studio.

LONDON : SEELEY $\&$ CO., LIMITED, 38 GREAT RUSSELL STREET, W.C. 


\section{PORTFOLIO MONOGRAPHS ON ARTISTIC SUBJECTS}

"A triumph of magnificent illustration and masterly editing." - The Times.

With many Illustrations, some in colours. Super-royal $8 \mathrm{vo}, 5 \mathrm{~s}$. nett, and in cloth, $7 \mathrm{~s}$. nett. Many of the Volumes are issued in two forms and at various nett prices. Where two prices are given, the first is that of the paper cover edition; the second that of the cloth. When only one price is given, the Volume is bound in paper only.

ANDERSON, Prof. W.

Japanese Wood Engravings. 2s. 6d. and 35. 6 d.

ARMSTRONG, Sir WALTER.

The Art of Velazquez. 3s. 6 d.

The Life of Velazquez. 3s. $6 \mathrm{~d}$.

The Peel Collection and the Dutch School of Painting. 5s. and 7s.

Thomas Gainsborough. Half-linen, 3s. 6d.

W. Q. Orchardson. 2s. 6d. and 3s. 6d.

BEDFORD, W. K. R.

Malta. 2s. $6 \mathrm{~d}$.

BENHAM, Canon, and CHARLES WELCH, F.S.A.

Mediæral London. 3s.6d., 5s., and 7 s.

The Tower of London. 5s. and $7 \mathrm{~s}$.

BENHAM, Canon.

Old St. Paul's Cathedral. 5s. and $7 \mathrm{~s}$.

BINYON, LAURENCE.

Dutch Etchers of XVIIth Century. 2s. 6d. and 3s. 6d.

John Crome and J. S. Cotman. 3s. 6d.

BIRCH, G. H., F.S.A.

London on Thames. 5s. and 7s.

CARTWRIGHT, JULIA (Mrs. ADY).

Jules Bastien-Lepage. 2s. 6d. and 3s. $6 \mathrm{~d}$.

The Early Work of Raphael. 2s. 6d. and 3s. $6 \mathrm{~d}$.

Raphael in Rome. 2s. 6d. and 3s. 6d.

CHURCH, A. H., F.R.S.

Josiah Wedgwood. 5s. and 7s.

CORNISH, C. J.

The Isle of Wight. 2s. $6 \mathrm{~d}$. and 3s. $6 \mathrm{~d}$.

The New Forest. 2s. 6d. and 3s. 6d.

CUST, LIONEL, F.S.A.

The Engravings of Albert Dürer. 2s. 6d. and 3s. 6d.

The Paintings and Drawings of Albert Dürer. 3s. $6 \mathrm{~d}$.

DAVENPORT, CYRIL, F.S.A.

Royal English Bookbindings. 35. 6d. and 45. 6 d.

Cameos. 5s. and $7 \mathrm{~s}$.

SeEley \& CO., Ltd., 37 Great Russell Street 
DAVIES, RANDALL, F.S.A.

English Society of the Eighteenth Century in Contemporary Art. DESTREE, O. G.

The Renaissance of Sculpture in Belgium. 2s. 6d. and 3s. 6d.

FLETCHER, W. Y.

Bookbinding in France. 2s. $6 \mathrm{~d}$. and $35.6 \mathrm{~d}$.

GARDNER, J. STARKIE.

Armour in England. 3s. $6 \mathrm{~d}$.

Foreign Armour in England. 3s. 6d.

GARNETT, RICHARD, C.B., LL.D.

Richmond on Thames. 3s. 6d. and 4s. $6 \mathrm{~d}$.

GRAHAME, GEORGE.

Claude Lorrain. 2s. 6d. and 3s. 6d.

HAMERTON, P. G.

The Etchings of Rembrandt. 2s. 6d. and 3s. 6d.

HUTTON, C. A.

Greek Terracotta Statuettes. 5s. and 7s.

LOFTIE, W. J.

Whitehall. 2s. 6d. and 3s. 6d.

MURRAY, A. S., LL.D.

Greek Bronzes. 3 s. $6 \dot{d}$. and 4 s. $6 \mathrm{~d}$.

NETTLESHIP, J. T.

George Morland. 5 s. and $6 \mathrm{~s}$.

PHILLIPS, CLAUDE.

Frederick Walker. 2s. 6d. and 3s. 6d.

Antoine Watteau. 2s. 6d. and 3s. 6d.

The Picture Gallery of Charles I. $3 \mathrm{~s}$. $6 \mathrm{~d}$.

The Earlier Work of Titian. 3s. 6d.

The Later Work of Titian. 3s. 6d.

POLLARD, ALFRED W.

Italian Book Illustrations. 2s. 6d. and 3s. 6d.

PRIOR, E. S., F.S.A.

The Cathedral Builders in England. 5s. and 7s

SHARP, WILLIAM.

Fair'Women. 2s. 6d. and 3s. $6 \mathrm{~d}$.

STEPHENS, F. G.

Dante Gabriel Rossetti. 2s. 6d.

STEVENSON, R. A. M.

Peter Paul Rubens. 3s. 6d.

WAERN, CECILIA.

John La Farge. 3s. 6d.

WEALE, W. H. JAMES.

Gerard David, Painter and Illuminator. 2s. 6d. and 3s. 6d.

SEELEY \& CO., Ltd., 38 Great Russell Street 
THE PORTFOLIO MONOGRAPHS, No. 46

With 4 Illuminations in Colours and Gold, and 33 other Illustrations. Price $5 s$. nett, or in cloth, 7s. nett

\section{THE CATHEDRAL \\ BUILDERS IN ENGLAND \\ By EDWARD S. PRIOR, M.A., F.S.A. Autbor of "A History of Gotbic Art in England" \&s.}

In this volume Mr Prior treats of the Great English Medizval Cathedrals, with special reference to the men by whom they were designed, and the craftsmen by whom they were erected. He thus characterizes the successive periods of Cathedral building in England :-

1. Norman, Benedictine, "Romanesque."

2. Angevin, Neomonastic, "Transitional to Gothic."

3. Insular, Episcopal, "Early English."

4 Continental, Regal, "The Summit of Gothic."

5. English, Aristocratic, "Decorated."

6. After the Black Death : Oficial, "Perpendicular."

7. Fifteenth Century: Parochial and Trading, "Perpendicular."

8. Sixteenth to Eighteenth Centuries: the Craftsman and the Architect.

9. Nineteenth Century : the Restorer and Revivalist.

\section{LIST OF ILLUSTRATIONS}

Menutukes, trom Illominatzo MSS. in the British Moszom, printed in Colovas. Christ in Glory. From a Missal of the Fourteenth Century.

The Angels with the Seren Vials. From an Apocalypse of the 14th Century Bishop carrying the Sacrament. From a Lectionary of the Fifteenth Century. Group of Bishops. From a Psalier of the Fifteenth Century.

\section{Othre Inustrations}

Westminster Abbey. Confessor's Chapel. Lincoln Cathedral, from the East. HoLlan. BorcE.

Westminster Abbey. N. Ambulatory. NAss.

Canterbury Cathedral, from the S. Holuax.

Durham Cathedral, from the River. Davisul.

Durham Cathedral, from the West. Cotmax.

Winchester Cathedral, N. Transept. BLORE.

Norwich Cathedral, Nave. F. Mackznziz.

Canlerbury Cathedral. N. Aisle of Choir. G. Cattramole.

Wells Cathedral, Arches under the Cestral Tower. Garland.

Wells Cathedral, N.W. Tower. J. H. Gibnons. Chichester Cathedral, S.E. View. GarlaND.

Sonthwark Cathedral, Nave. DibDr.s.

Salisbury Carbedral, Small Transept. F. MACKENZ1E.

York Minster, from the North. ED. BLokE. York Minster, North Transept. Garland. Lincoln Cathedral, from the West. $\mathrm{Dr}$ Wint. Lincoln Cathedral, the Chancel. Garland.
Salisbury Cathedral, the Chapter Honse. F. Mackenziz.

Salisbury Cathedral, from Cloisters. Turner. Exeter Cathedral, from the S.E. S. RAYNEx. Ely Cathedral, the Octagon. Garland.

Gloncester Cacbedral, Presbytery. J. Harold GisBons.

Gloucester Cathedral, Cloisters. Garland.

York Minster, East End. F. Macxenzue.

Winchester Cathedral, West Front. Garland.

York Minster, Cboir. F. MACKENzJE.

Sherborne Minster. Constable.

St George's Chapel, Windsor, from S. Howlax.

St George's Chapel, Windsor, Interior of Choir. Hollar.

St Paul's Cathedral, West Front. T. MALToN. St Paul's Catbedral, Interior of Choir. $\mathbf{R}$ TREVITT.

Truro Calhedral, from the Sonth-East.

"An extremely suggestive and stimulating essay. . . Certainly gives renewed interest to the study of the Cathedrals." - Manchester Gwardian.

"One of the fine "Portfolio Monographs." . . The reader can hardly fail to derive keen artistic pleasure from the series of illustrations." - Scotsman.

London: SeEley \& COMPANY, Limited, $3^{8}$ Great Russell Stregt 


\section{NEW AND NOTABLE BOOKS \\ A TRANSFORMED COLONY \\ SIERRA LEONE}

AS IT WAS, AND AS IT IS, ITS PROGRESS, PEOPLES, NATIVE

CUSTOMS, AND UNDEVELOPED WEALTH

BY T. J. ALLDRIDGE, I.S.O., F.R.G.S.

Formerly Travelling Commissioner in the Upper Mendi Country and for many years District Commissioner of the Sherbro in the Crown Colony of Sierra Leone Anthor of "The Sherbro and its Hinterland"

With Sixty-six Illustrations and a Map. Demy 8vo. 16s. net.

Mr. Alldringe is one of very few who saw the colony emerge from the darkness of barbarism, and knew its peoples intimately in their primitive state. This renders his record particularly valuable, as he is able to describe with great minuteness many habits and customs now long past, and his description of the secret societies is extremely interesting.

He did pioneer work in opening up and mapping out the far distant and unknown parts of the Hinterland. He tells us of the causes which led to the forming of the Protectorate, and on behalf of the Government made many treaties with powerful chiefs whose names are known to history. So far from deserving the opprobrium under which it so long laboured, the author paints an exceedingly fair land, the salubrity of which will yield to few other places, and says that the natural resources of the country are such that with some energy and a little capital to develop them, the colony might be rendered one of the richest dependencies of the Crown.

The photographs taken by the author himself are of a delightfully varied character, and illustrate every subject on which he touches.

\section{TO ABYSSINIA THROUGH AN UNKNOWN LAND}

AN ACCOUNT OF $\triangle$ JOURNEY THROUGH UNEXPLORED REGIONS OF BRITISH EAST AFRICA AND THE LAKE RUDOLF TO THE KINGDOM OF MENELIK

\section{By Captain C. H. S'IIGAND, F.R.G.S., F.Z.S. \\ West Kent Regiment \\ With 36 Illustrations and a Map. Demy 8vo, 16s. net.}

Captain STIGAND is an explorer, big-game hunter, and a naturalist, and his experiences and adventures on his journey through the unexplored regions from Gilgil south of Lake Rudolf to Addis Ababa in Abyssinia form a book of intense interest. He faced many dangers both from wild beasts and human beings, but perhaps the greatest of all was the danger of not finding water. He and his band of natives, who were his only companions, tramped for days under a broiling sun over arid plains, through ankle-deep dust or broken lava with the smallest possible allowance of water to cool their parched throats at the end of each day. Much of the ground covered had never before been trodden by the foot of any white man, and, owing to the lack of water, was emphatically declared by earlier explorers and the natives to be impassable.

His tact and firmness kept together his band of porters, and conciliated the natives, and intending travellers in the wilds of Africa could not do better than adopt some of his methods in this respect. It is worthy of note that this judicious handling of his men so inspired them with confidence, that from being a timorous and insubordinate crew, they became his devoted followers ready to encounter any danger which he himself was willing to face.

The book is authoritative and informative, and the author's sense of humour makes it extremely pleasant reading. The photographs are beyond question perfectly unique, and possess the merit, so rare in the case of books of travel, of illustrating the text.

$$
\text { SEEley \& CO., Ltd., } 38 \text { Great Russell Street }
$$




\section{THE SCIENCE OF TO-DAY SERIES}

With many Illustrations. Extra Crown 8vo. 58. net.

AERIAL NAVIGATION OF TO-DAY. A Popular Account of the Erolution of Aeronautics. By Charles C. TURNER.

"If ever the publication of a book was well timed, surely it is the case with this book on ariation. . . O Of the technical chapters we need only say that they are so simply written as to present no grave difficulties to the beginner who is equipped with an average educa. tion."-Globe.

BOTANY OF TO-DAY. A Popular Account of the Erolution of Modern Botany. By Prof. G. F. Scotr-Elilor, M.A., B.Sc., Author of "The Romance of Plant Life," Ecc. Erc.

"This most entertaining and instractive book. It is the fruit of wide reading and much patient industry."-Globe.

SCIENTIFIC IDEAS OF TO-DAY. A Popular Account, in Non-technicsl Language, of the Nature of Jiatter, Electricity, Light, Heat, Electrons, Esc. Esc. By Charles R. GiBson, F.R.S.E., Author of "Electricity of To-Day," \&-c.

"As a knowledgeable writer, gifted with the power of imparting what he knows in a manner intelligible to all, Mr. C. R. Gibson has established a well-deserved reputation."-Field.

ASTRONOMY OF TO-DAY. A Popular Introduction in Non-technical Language. By Cecil G. Dolmage, LL.D., F.R.A.S. With frontispiece in colours, \& 45 other illustrations. Times.

"A lacid exposition much helped by abundant illustrations."-The

"From cover to cover the book is readable, and every word is in. telligible to the layman. Dr. Dolmage displays literary powers of a very high order. Those who read it withont any previous knowledge of astronomy will find that a new interest has been added to their lives, and that in a matter of 350 pages they have gained a true con. ception of the meaning of astronomy." - The Standard.

ELECTRICITY OF TO-DAY. Its Work and Mysteries Explained. By Charles R. Gibson, F.R.S.E.

"Mr. Gibson has given us one of the best examples of popular scientific exposition that we remember seeing. His aim has been to produce an account of the chief modern applications of electricity withont using technical langnage or making any statements which are beyond the comprehension of any reader of ordinary intelligence. In this he has succeeded to admiration, and his book may be strongly commended to all who wish to realise what electricity means and does in our daily life."-The Tribure.

SEELEY E CO., Ltd., 38 Great Rusgrll Stregt 


\section{A MILITARY CONSUL IN TURKEY}

\section{By Captain A. F. TOWNSHEND}

Late of the Scottish Rifles, Sometime British Military Consul at Adrianople and at Mersina, Asia Minor

With many Illustrations and a Map. Demy 8vo. 16s, net.

"Every word of Captain Townshend's book is worth reading."-Pall Mall Gazette.

"It leaves no department of Turkish life untouched."-Scotsman.

"Full of interest. . . . It embodies valuable information."-Westminster Gazette.

"Straightforward, sensible, and unbiassed."-The Queen.

"Crowded with instructive experiences which give one a clearer and sounder impression than volumes of more pretentious work."-Daily Mail.

\section{FAMILY NAMES AND THEIR STORY \\ By THE REv. S. BARING-GOULD}

Demy 8vo, 7s. 6d. net

"Extremely interesting and suggestive; written on popular lines and in lively style."-Scotsman.

"No living writer is more competent to deal with this subject than Mr. Baring Gould."-Church Family Newspaper.

"An immense mass of detailed information."-Times.

"This most entertaining of volumes; of absorbing human interest." Evening Standard.

“We might wander for hours among Mr. Baring-Gould's pleasant and instructive pages, and we heartily commend them to any one who wants to know what his own name means, or how much of the history of the country is enshrined in those of his friends."-Globe.

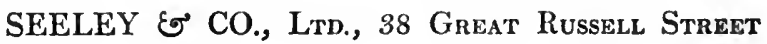




\section{RECENT NOTABLE BOOKS \\ AMONG THE WILD TRIBES OF THE AFGHAN FRONTIER}

$\triangle$ RECORD OF SIXTEEX YBARS'"CLOSB INTERCOURSE WITH THE NATITES OF THB INDIAN MARCHES

BY T. L. PENNELL, M.D., B.Sc., F.R.C.S.

WITH AN INTRODCCTION BY

FIELD-MARSHAL EARL ROBERTS, V.C., K.G.

With Thirty-seven Illustrations and Two Maps. Demy 8vo. 16s. net. THIRD EDITION

"A full and modest record of a work of the ralue of which Lord Roberts speaks highly, and throws many new sidelights on the wild border tribesmen." -Times.

"A brilliant example of what can be done (and what is being done in nearly all the dark quarters of the world) by one resolute man who is fired with the spirit that animated the early disciples. . . . His book can be warmly commended, too, to those who merely delight in narratives of trarel and adventure."-Daily Mail.

"A veritable storehouse of facts and deductions presented in most attractive fasbion."-Daily Telegraph.

"A record of real merit, a record of brave work, travel, and no little adventure, told without pretentiousness, and lightened by a true literary sense and much humour."-Guardian.

"The whole book is interesting in the highest degree."-Spectator.

"Seldom does a volume appear of such immediate and absorbing interest." -Graphic.

\section{BEHIND THE VEIL IN PERSIA AND TURKISH ARABIA}

AN ACCOUNT OF AN BXGLISHWOMAN'S BIGHT YEARS' RESIDENCB AMONGST THE WOMEN OF THE BAST

By M. E. HUME-GRIFFITH

With Thirty-seven Mlustrations and a Map. Demy 8vo. 16s. net. SECOND EDITION

"The writing is good ; there is vivacity, humour, and careful observation in the chapters, and much valuable information is conveyed."-Evening Standard.

"Anthoritative and deeply interesting."-Daily Neurs.

"A book that adds to one's koowledge of eastern life in its most intimate phases, and we are grateful to the writers for having set out their experiences so clearly and straightforwardly."- Westminster Gazette.

"Written attractively and without pretence or ostentation. It is accom. panied by excellent photographs which bave the rare merit of really illustrating the text."-Manchester Guardian.

"A book full of human interest... gives a better idea of the land of Hajji Baba than any book we remember."-Morning Post.

SEElEy E CO., Ltd., 38 Great Russell Street 


\section{THE PORTFOLIO MONOGRAPHS, No. 45}

With Four Photographic Plates, and many other Illustrations Price 5s. nett, or in cloth, 7s. nett

\section{THE PEEL COLLECTION \\ AND THE}

\section{DUTCH SCHOOL OF PAINTING}

\section{By SIR WALTER ARMSTRONG}

The Peel Collection in the National Gallery is chiefly famous for its fine group of works by the Dutch painters of the Seventeenth Century (excluding Rembrandt and his followers). It is with these artists that Sir Walter Armstrong's monograph deals.

"Vastly interesting to read . . . charmingly illustrated."-Acadewy.

"A model of what such a study should be."-Standard.

\section{LIST OF ILLUSTRATIONS}

\section{PHOTOGRAVURE PLATES}

The Guitar Lesson. By Gerard The Avenue. By Hobbrma TERBORCH

The Court of a House. By Pirtre dr Chapeau de Poil. By Rubzns

Hooch

Other ILLUSTrations

A Family Portrait. By Gonzales The Interior of a Stable. By P. Coquzs

On the Maas. By Curp

A Ruined Castle. By Cuyp

A Dutch Interior. By Piztzr ar. Hooch

The Duet. By G. Mersu

The Music Lesson. By G. Mrtsu

The Alchemist. By A. van Ostade

A Village Scene. By I. van Ostadr

Landscape and Cattle. By Paur PotTzR

WouwERMaN

On the Sea Shore. By P. Wouwrrman

Blowing Bubbles. By Netscher

The Farm Cottage. By A. van dE Vexpr

Frost Scene. By A. van dr. Ver.dz

A Gale. By W. vaN DE VELDE

A Lady Feeding a Parrot. By F. van Mieris

Landscape with Figures. By JAN WrNANTS

The Triumph of Silenus. By Rubens

The Waterfall. By JaKoB VAN RUISDAEL

The Music Master. By Jan Steen

The Surprise. By D. Teners (the Younger)

The Poulterer's Shop. By Gerard Dou

Figures and Animals in a Meadow. By KAREL DU J ARDIN

A Street in Cologne. By J. van der HeYden

London: SEELEY \& COMPANY Limited, 38 Great Russell Street 


\title{
THE ROMANCE OF MODERN PHOTOGRAPHY
}

\author{
ITS DISCOVERY
}

\author{
By C. R. GIBSON \\ ALTHOR OF " BLBCTRICITY OP TO-DAY," MTO.
}

"Mr. Gibson tells the romantic story of the discovery of this won. derful art, and the steps by which its range has been extended, until it can achieve results which only a few rears ago would have been thought impossible."-Nerocastle Chronicle.

"The explanation of the complicated system of photographing in colours is particularly lucid, and, indeed, the narrative is everywhere remarkable for its fluency and clear style."-Bystunder.

"Should prove one of the most popular and fascinating of this writer's books, and will interest all who are connected with photog. raphy."-The Photographic Monthly.

"A fascinating story of triumpbs of thought and patience, and illustrated with remarkable photograpbs."-Church Times.

"The author has made his book remarkably comprehensive, while there is not a dry or nninteresting page thronghont."-Country Life.

\section{THE ROMANCE OF MODERN GEOLOGY}

\author{
By E. S. GREW, M.A.
}

With Twenty-five Illustrations. Extra Croun 8vo. 5s.

"Mr. Grew possesses the golden gift of a graceful style as well as a complete mastery of his subject, and he has written a popular intro. duction to modern geology which any one can read with pleasure and anderstand from beginning to end."-Daily Graphic.

"A fascinating outline filled in with many valuable facts and much well-founded knowledge of the history and animal life of the earth." Shefield Daily Telegraph.

"Mr. Grew has done extremely good work in this volume of Messro. Soeley's excellent 'Library of Romance.' He is one of the few wen who can make special knowledge interesting to the general reader. . . . The illustrations are singularly felicitous."-Daily Telegraph.

\section{SEeley \& CO., Ltd., 38 Great Russell Street}


Demy 8vo, 415 Illustrations, gilt top, 16s. nett

\section{A Nere and Fascinating Work on Primitive Man The Childhood of Man \\ A POPULAR ACCOUNT \\ OF THE LIVES, CUSTOMS AND THOUGHTS \\ OF THE PRIMITIVE RACES \\ BY \\ DR. LEO FROBENIUS}

TRANSLATED BY

PROF. A. H. KEANE, LL.D., F.R.G.S.

Late Vice-President of the Royal Anthropological Institute of Great Britain, Author of "Ethnology:" Man Past and Present," Eंo., \&c.

With 415 Illustrations

\section{PRESS NOTICES}

"A book full not only of interesting facts, but of fascinating speculations. The numerous illustrations make the book doubly helpful, and doubly interesting."Daily Neres.

"A book brimful of interest, which sums up in picturesque fashion all that is known on the subject."-

Evening Standard.

"The general reader will find much that is entertaining in 'The Childhood of Man,' while the student cannot afford to overlook it."-Dr A. C. Haddon in The Nation.

"Brightly written and well got up."

-Western Daily Press.

"The work is a distinct addition to our knowledge of this rapidly growing science."-Aberdeen Free Press.

"Professor Keane is an authority of high standing in the study of anthropology and ethnology."-Times.

"The illustrations alone, of which there are 415 , will ensure a welcome for this excellent version of Dr Frobenius' important book."-British Weekly.

SEELEY \& CO, LD, 38 GREAT RUSSELL ST, W C 


\section{A Catalogue of Books on Art,}

History, and General Literature Published by Seeley $\oiint^{\circ}$ Co Ltd 38 Great Russell Street, London

Some of the Contents

Elzevir Library .

Events of Our Own Times Series . . 6

Miniature Library of Devotion . . 9

Miniature Portfolio Monographs . . Io

New Art Library . . . . . II

Portfolio Monographs . . . . I2

Science of To-Day Series . . . . 14

Seeley's Illustrated Pocket Library - . I4

Seeley's Standard Library •. . . . I 5

Things Seen Series : . . . ${ }_{1} 6$

The Publishers will be pleased to post their complete Catalogue or their Illustrated Miniature Catalogue on receipl of a post-card 


\section{CATALOGUE OF BOOKS}

\section{Arranged alphabetically under the names of Authors and Series}

ABBOTT, Rev. E. A., D.D.

Hints on Home Teaching. Crown 8vo, 3 s.

How to Parse. An English Grammar. Fcap. 8vo, 3s. 6d.

How to Tell the Parts of Speech. An Introduction to English Grammar. Fcap. 8vo, 2s.

How to Write Clearly. Rulesand Exercises on English Composition. Is. 6d. Latin Gate, The. A First Latin Translation Book. Crown 8vo, 3s. 6d.

Via Latina. A First Latin Grammar. Crown 8vo, 3s. 6d.

ABBOTT, Rev. E. A., and Sir J. R. SEELEY.

English Lessons for English People. Crown 8vo, 4s. 6d.

ADY, Mrs. See Cartwright, Julia.

A KEMPIS, THOMAS.

Of the Imitation of Christ. With Illuminated Frontispiece and Title Page, and Illuminated Sub-Titles to eacb book. In white or blue cloth, with inset minia. tures. Gilt top; crown $8 \mathrm{vo}, 6 \mathrm{~s}$. nett ; 2lso in vellum, ros. 6 d. nett.

"It may well be questioned whether the great work of Thomas a Kempis has ever been presented to better advantage." - The Gxardian.

ALLDRIDGE, T. J., I.S.O., F.R.G.S.

A Transformed Colony. Sierra Leone as it was and as it is. With Sixty-six Illustrations and a Map. Demy 8vo, x6s. nett.

ANDERSON, Prof. W.

Japanese Wood Engravings. Coloured Illustrations. Super-royal 8ro, sewed, 2s. 6d. nett ; half-linen, 3s. 6d. nett ; also small 4to, cloth, 2s. nett ; lambskin, 3s. nett.

ARMSTRONG, Sir WALTER.

The Art of Velazquez. Illustrated. Super-royal 8vo, 3s. 6d. nett.

The Life of Velazquez. Illustrated. Super-royal 8vo, 3s. 6d. nett.

Velazquez. A Study of his Life and Art. With Eight Copper Plates and many minor Illustrations. Super-royal $8 \mathrm{vo}$, cloth, 95 . nett.

Thomas Gainsborough. Illustrated. Super-royal 8ro, half-linen, 3s. 6d. nett. Also new edition, small 4 to, cloth, 28. nett ; leatber, 3 s. nett and 5s. nett.

The Peel Collection and the Dutch School of Painting. With many Illustrations. Super-royal $8 v 0$, sewed, 5s. nett; cloth, 75 . nett.

W. Q. Orchardson. Super-royal 8vo, sewed, 2s. 6d. ; half-linen, 3s.6d. nett. AUGUSTINE, S.

Confessions of S. Augustine. With Illuminated pages. In white or blue cloth, gilt top, crown 8vo, 6s. nett; also in vellum, ros. 6d. nett.

BARING-GOULD, Rev. S.

Family Names and their Story. Demy 8vo, 7s.6d. nett.

Cliff Castles and Cave Dwellings of Europe. With 54 Illustrations and Diagrams. Demy 8vo, x2s. 6d. nett.

BEDFORD, Rev. W. K. R.

Malta and the Knights Hospitallers. Super-royal 8vo, sewed, 2s. 6d. nett; half-linen, 3 s. $6 \mathrm{~d}$. nett.

BENHAM, Rev. Canon D. D., F.S.A.

The Tower of London. With Four Plates in Colours and many other Illustrations. Super-royal 8vo, sewed, 5s. nett; clotb, 7s. nett.

Medizval London. With a Frontispiece in Photogravure, Four Plates in Colour, and many other Mllustrations. Super-royal 8vo, sewed, 5s. nett; cloth, gilt top, 7s. nett. Also extra crown 8vo, $3 \mathrm{~s}$. $6 \mathrm{~d}$. nett.

Old St. Paul's Cathedral. With a Frontispiece in Photogravure, Four Plates printed in Colour, and many other Illustrations. Super-royal 8vo, sewed, 55. nett or cloth, gilt top, 7s. nett. 


\section{Seeley $\xi^{\circ}$ Co Limited}

BICKERSTETH, Rev. E.

Family Prayers for Six Weeks. Crown 8vo, 3s. 6d.

A Companion to the Holy Communion. $32 \mathrm{mo}$, cloth, Is.

BINYON, LAURENCE.

Thomas Girtin: His Life and Works. An Essay. With Twenty-one Reproductions in Autotype. Imperial 4 to, 62, 2s. nett.

Dutch Etchers of the Seventeenth Century. Illustrated. Super-royal 8vo, sewed, 2s. 6d.; half.linen, 3s. 6d. nett.

John Crome and John Sell Cotman. Illustrated. Super-royal 87o, sewed, 3s. 6d. nett.

BIRCH, G. H.

London on Thames in Bygone Days. With Four Plates printed in Colour and many other Illustrations. Super-royal 8vo, sewed, 5s nett; cloth, 7s. nett.

BRIDGES, Rev. C.

An Exposition of Psalm CXIX. Crown 8vo, 5 s.

BUTCHER, E. L.

Things Seen in Egypt. With Fifty Illustrations. Small 4to, cloth, 2s. nett; lambskin, 3s. nett; velvet leather, in box, $5 \mathrm{~s}$. nett.

CAMERON, D. Y.

Six Etchings by D. Y. Cameron and William Strang. Imperial 4to, 6s nett.

CARTWRIGHT, JULIA.

Jules Bastien-Lepage. Super-royal 8vo, sewed, 2s. 6d.; cloth, 3s. 6d. nett. Sacharissa. Some Account of Dorothy Sidney, Countess of Sunderland, ber Family and Friends. With Five Portraits. Demy 8vo, 75. 6d.

Raphael in Rome. Illustrated. Super-royal 8vo, sewed, 2s. 6d. ; halflinen, 35 . 6d. nett; also in small 4 to, cloth, $2 \mathrm{~s}$ nett; leather, $3 \mathrm{~s}$. nett and 55 . nett.

The Early. Work of Raphael. Illustrated. Super-royal 8vo, sewed 2s. 6d.; halfolinen, 3s. 6d. Also new edition, revised, in small 4to, in cloth, 2s. nett; leather, 3s. nett.

Raphael : A Study of his Life and Work. With Eight Copper Plates and many osher Illustrations. Super-royal 8vo, 75. 6d. nett.

CESARESCO, The Countess MARTINENGO.

The Liberation of Italy. With Portraits on Copper. Crown 8vo, 5s.

CHITTY, J. R.

Things Seen in China. With Fifty Illustrations. Small 4to; cloth, 2s.;

leather, $3 \mathrm{~s}$; velvet leather in 2 box, $5 \mathrm{~s}$. nett.

CHORAL SERVICE-BOOK FOR PARISH CHURCHES, THE.

Compiled and Edited by J. W. ElLtorT, Onganist and Choirmaster of St. Mark's,

Hamilson Terrace, London. With some Practical Counsels taken by permission from

"Notes on the Church Service," by Bishop Walsham How.

A. Royal $8 \mathrm{vo}$, sewed, is.; cloth, is. $6 \mathrm{~d}$.

B. $16 \mathrm{mo}$, sewed, $6 \mathrm{~d}$. ; cloth, $8 \mathrm{~d}$.

The following portions may be had separately :-

The Ferial and Festal Responses and the Litany. Arranged by J. W. ElLioTt. Sewed, 4 d.

The Communion Service, Kyrie, Credo, Sanctus, and Gloria in

Excelsis. Set 10 Music by Dr. J. NAYLoR, Organist of York Minster. Sewed, 4d. 


\section{Seeley $\mathscr{G}^{\circ}$ Co Limited}

CHURCH, Sir ARTHUR H., F.R.S.

Josiah Wedgwood, Master Potter. With many Illustrations. Superroyal $8 \mathrm{vo}$, sewed, 5s. nett ; cloth, $7 \mathrm{~s}$. nett ; also small 4 to, cloth, $2 \mathrm{~s}$. nett; leather, 35. and 5s. nett.

The Chemistry of Paints and Painting Third Edition. Crown 8vo, 6s.

CHURCH, Rev. A. J.

Nicias, and the Sicilian Expedition. Crown 8vo, Is. 6d.

For other books by Professor Church see Complete Catalogue.

CLARK, J. W., M.A.

Cambridge. With a coloured Frontispiece and many other Illustrations by A. Brunet-Debaines and H. Toussaint, Ec. Extra crown 8vo, 6s. ; also crown 8vo, cloth, 2s. nett; leather, 3s. ; special leather, in box, 5s. nett.

CODY, Rev. H. A.

An Apostle of the North. The Biography of the late Bishop Bompas, First Bishop of Athabasca, and with an Introduction by the ARCHBishop of RUPERTsLAND. With 42 Illustrations. Demy 8vo, 7s. 6d. nett.

COLVIN, Sir AUCKLAND, K.C.S.I., K.C.M.G.

The Making of Modern Egypt. Fourth Edition. With Portraits and a Map. Demy 8vo, r8s. nett.

CORBIN, T. W.

Engineering of To-day. With Seventy-three Illustrations and Diagrams. Extra crown 8 vo, 5 s.

CORNISH, C. J.

Animals at Work and Play: Their Activities and Emotions. With Twelve Illustrations. Second Edition. Crown 8vo, 6s.

Animals of To-day: Their Life and Conversation. With Illustrations from Photographs by C. REid of Wishaw. Crown 8vo, 6s.

The Isle of Wight. Illustrated. Super-royal 8vo, sewed, 2s. 6d. nett; half-linen, 3s. $6 \mathrm{~d}$. nett; also a new edition, small 4 to, cloth, 2s. ; leather, $3 \mathrm{s.}$

Life at the Zoo. Notes and Traditions of the Regent's Park Gardens. Illustrated from Photographs by Gambier Bolton. Fifth Edition. Crown 8vo, 6s.

The Naturalist on the Thames. With many Illustrations. Demy 8ro, 7s. $6 \mathrm{~d}$.

The New Forest. Super-royal 8vo, sewed, 2s. 6d. nett; half-linen, 3s. 6d. nett ; also new edition, small 4 to, cloth, $2 \mathrm{~s}$.; leather, $3 \mathrm{~s}$. nett ; and special velvet leather, each copy in a box, 5 s.

The New Forest and the Isle of Wight. With Eight Plates and many other Illustrations. Super-royal 8vo, 7 s. $6 \mathrm{~d}$. nett.

Nights with an Old Gunner, and other Studies of Wild Life. With Sixteen Illustrations by Lancelot SpeEd, Charlas Whymper, and from Photographs. Crown 8vo, 6s.

Wild England of To-day and the Wild Life in it. With Sixteen Illustrations from Drawings by LANCELOT SPEED, and from Photographs. Crown 8vo, $6 \mathrm{~s}$.

\section{CUST, LIONEL.}

The Engravings of Albert Dürer. Illustrated. Super-royal 8vo, halfinen, 3s. 6d. nett.

Paintings and Drawings of Albert Dürer. Illustrated. Super-royal 8vo, sewed, 3s. 6 d. nett.

Albrecht Dürer. A Study of his Life and Work. With Eight Copper Plates and many other Illustrations. Super-royal 8vo, 7s. 6d. 


\section{Seeley $\circledast^{\circ}$ Co Limited}

DALE, J. M.

The Clergyman's Legal Handbook and Churchwarden's Guide.

Seventh Edition. Revised and brought up 20 date by J. S. RiscEY. 7s. 6d.

\section{DAVENPORT, CYRIL.}

Cameos. With examples in Colour and many other Illustrations. Superroyal $8 \mathrm{vo}$, sewed, 5s. nett; cloth, 7s. nett.

Royal English Bookbindings. With Coloured Plates and many other Illustrations. Super-royal 8vo, sewed, 35. 6d. ; cloth, 4s. 6d.

\section{DAVIES, RANDALL, F.S.A.}

English Society of the Eighteenth Century in Contemporary Art. With Four Coloured and many otber Illustrations. Super royal 8vo, sewed, 5s. nett; cloth, 7s. nett.

\section{DAWSON, Rev. E. C.}

The Life of Bishop Hannington. Crown 8vo, paper boards, 2s. 6d.; or with Map and Illustrations, cloth, 3s. 6d.

\section{DESTREE, O. G.}

The Renaissance of Sculpture in Belgium. Illustrated. Super-royal 8vo, sewed, 2s. 6d. nett; half-linen, 3s. 6d. nett.

\section{DOLMAGE, CECIL G., M.A., D.C.L., LL.D., F.R.A.S.}

Astronomy of To-Day. A popular account in non-technical language. With Forty-six Illustrations and Diagrams. Extra crown 8ro, 5s. nett.

\section{EARDLEY, WILMOT, Rear-Admiral S.}

Our Fleet To-day and its Development during the last Half Century.

With many Illustrations. Crowa 8vo, 5s.

\section{ELZEVIR LIBRARY, THE.}

Selections from the choicest English Writers. Exquisitely Illustrated, with Frontispiece and Title-page in Colours by H. M. Brock, and many other Illustrations. Half bound in cloth, gilt top, Is. 6d. nett; full leather, 2s. nett; velvet leather, gilt edges, in 2 box, 35. net?.

Volume I. Fancy \& Humour of Charles Lamb.

, II. Wit \& Imagination of Benjamin Disraeli.

"III. Vignettes from Oliver Goldsmith.

"IV. Wit \& Sagacity of Dr. Johnson.

, V. Insight and Imagination of John Ruskin.

" VI. Vignettes of London Life from Dickens.

"VII. XVIIIth Century Vignettes from Thackeray.

" VIII. Vignettes of Country Life from Charles Dickens.

", IX. Wisdom and Humour of Thomas Carlyle.

"Decidedly natty and original in get-up."-The Saturday Revirw. 


\section{Seeley $\mathscr{\vartheta}^{\circ}$ Co Limited}

\section{EVENTS OF OUR OWN TIMES}

Crown 8vo. With Illustrations, 5s. each.

The War in the Crimea. By General Sir E. Hamley, K.C.B. With Copper Plates and other Illustrations. 5 s.

The Indian Mutiny. By Colonel Malleson, C.S.I. With Copper Plates and other Illustrations. 5 s.

The Afghan Wars, I839-42, and 1878-80. By ARchibald Forbes. With Portraits and Plans. 55.

Our Fleet To-Day and its Development during the last Half Century. By Rear-Admiral S. EARDLRY WILMOT. With many Illusirations. 5 s.

The Refounding of the German Empire. By Colonel Malleson, C.S.I. With Portrait and Plans. 55.

The Liberation of Italy. By the Countess Martinengo Cesaresco. With Portraits on Copper. 5s.

Great Britain in Modern Africa. By Edgar Sanderson, M.A. With Portraits and a Map. 5 s.

The War in the Peninsula. By A. Innes Shand. With Portraits. $5 \mathrm{~s}$

FERRAR, NICHOLAS.

The Story Books of Little Gidding: Being the Religious Dialogues recited in the Great Room at Little Gidding Hall, $16_{3} \mathrm{I}-2$. From the Original Manuscript of Nicmolas FrRrar. With several Illustrations. Crown 8ro, 6s.

FLETCHER, W. Y.

Bookbinding in England and France. Seventeen Coloured Plates and many orher Illustrations. Super-royal 8vo, $7 \mathrm{~s}$. $6 \mathrm{~d}$. nett.

Bookbinding in France. Coloured Plates. Super-royal, sewed, 2s. 6d. nett; half-linen, 3s. $6 \mathrm{~d}$. nett.

FORBES, ARCHIBALD.

The Afghan Wars of $1839-1842$ and $1878-1880$. With Four Portraits on Copper, and Maps and Plans. Crown 8vo, 5 s.

FRASER, Sir ANDREW, H.L.

Among Indian Rajahs and Ryots. With 34 Illustrations and a Map. Demy 8vo, 18s. nett.

FRIPP, Sir ALFRED D., K.C.V.O., \& R. THOMPSON, F.R.C.S. Human Anatomy for Art Students. Profusely Illustrated with Photographs and Drawings by INNES FrIPP, A.R.C.A. Square extra crown 8vo, 6s. nett.

FROBENIUS, LEO.

The Childhood of Man. A Popular Account of the Lives and Thoughts of Primitive Races. Translated yy Prof. A. H. KeANE, LL.D. With 4 I6 Illustrations. Demy 8vo, 16s. nett.

FRY, ROGER.

Discourses Delivered to the Students of the Royal Academy by Sir

Joshua Reynolds. With an Introduction and Notes by ROGER FRY. With Thirty-three Illustrations. Square Crown 8vo 7s. 6d. nett.

GARDNER, J. STARKIE.

Armour in England. With Eight Coloured Plates and many other Illustrations. Snper-royal 8vo, sewed, 3s. 6d. nett.

Foreign Armour in England. With Eight Coloured Plates and many other Illustrations. Super-royal 8vo, sewed, 3s. 6d. nett.

Armour in England. With Sixteen Coloured Plates and many other Illustrations. The two parts in one volume. Super-royal 8vo, clotb, gilt top, gs. nett.

GARNETT, R., LL.D.

Richmond on Thames. Illustrated. Super-royal 8vo, sewed, 3s. 6d. nett. 


\section{Seeley $\mathscr{\theta}^{\circ}$ Co Limited}

GIBERNE, AGNES.

Beside the Waters of Comfort. Crown 8vo, 3s. 6d.

GIBSON, CHARLES R., A.I.E.E.

Electricity of To-Day. Its Works and Mysteries described in nontechnical language. With 30 Illustrations. Extra crown 8 vo, 5s. nett.

"One of the best examples of popular scientific exposition we remember seeing."-The Tribune.

Scientific Ideas of To-day. A Popular Account in non-technical language of the Nature of Matter, Electricity, Light, Heat, \& c., Evc. With 25 Illustrations. Extra crown 8vo, 5s. nett.

How Telegraphs and Telephones Work. With many Illustrations. Crown 8vo, 1s. 6à. nett.

The Autobiography of an Electron. With Eight Illustratious. Long 8vo, 3s. 6d. nett.

GODLEY, A. D.

Socrates and Athenian Society in his Day. Crown 8vo, 4s. 6d. Aspects of Modern Oxford. With many Illustrations. Crown 8ro, cloth, 25. nett; lambskin, 35 . nett; velvet leather, in box, 5 s, nett.

GoldEN RECiter. (See James, Prof. Cairns.)

GOMES, EDWIN H., M.A.

Seventeen Years among the Sea Dyaks of Borneo. With 39 Illustrations and a Map. Demy 8vo, 16s. nett.

GRAHAME, GEORGE.

Claude Lorrain. Illustrated. Super-royal 8vo, 2s. 6d. nett; half-linen, 35. 6d. Deth.

GRIFFITH, M. E. HUME.

Behind the Veil in Persia and Turkish Arabia. An Account of an Englishwoman's Eight Years' Residence amongst the Women of the East. With 37 Illustrations and a Map. Demy 8vo, 16s. nett.

GRINDON, LEO. Lancashire. Brief Historical and Descriptive Notes. With many
Illustrations. Crown 8vo, 6s.

GRUBB, W. BARBROOKE.

An Unknown People in an Unknown Land. With 40 Illustrations and a Map. Demy 8vo, 165, nett.

HADOW, W. H. A Croatian Composer. Notes toward the Study of Joseph Haydn.
Crown 8vo, 2s. 6d. nett.

Studies in Modern Music. First Series. Berlioz, Schumann. Wagner. With an Essay on Mnsic and Musical Criticism. With Five Portraits. Crown 8vo, 75. 6d. Studies in Modern Music. Second Series. Chopin, Drorak, Brahms. with an Essay on Musical Form. With Four Portraits. Crown 8vo, 7s. 6d.

HAMERTON, P. G.

The Etchings of Rembrandt, and Dutch Etchers of the Seventeenth Century. By P. G. Hamgrton and LaURence Binvon. With Eight Copper Plates and many other illustrations. Super-royal 8vo, 75. 6d. nett.

The Mount. Narrative of a Visit to the Site of a Gaulish City on Mount Benvray. With a Description of the neighbouring City of Autun. Crown 8vo, $35.6 \mathrm{~d}$. Round my House. Notes on Rural Life in Peace and War. Crown 8vo, with Illustrations, 2s. 6d. nett. Cheaper edition, 2s. nett.

Paris. Illustrated. New edition. Cloth, 2s. nett; leather, 3s. nett in special leather, full gilt, in box, 55 . nett. 


\section{Seeley $\mathscr{\sigma}^{\circ}$ Co Limited}

HAMLEY, Gen. Sir E.

The War in the Crimea. With Copper Plates and other Illustrations. Crown 8vo, 5 s.

Cheap Edition, paper cover. Demy 8vo, 6d. nett.

HARTLEY, C. GASQUOINE.

Things Seen in Spain. Wich Fifty Illustrations. Small 4to, cloth, 2s.; leather, 3s. ; velvet leather in a box, 5s. nett.

HENDERSON, Major PERCY E.

A British Officer in the Balkans. Through Dalmatia, Montenegro, Turkey in Austria, Magyarland, Bosnia and Herzegovina. With 50 Illustrations and a Map. Gilt top. Demy 8vo, x6s. nett.

\section{HERBERT, GEORGE.}

The Temple. Sacred Poems and Ejaculations. The Text reprinted from the First Edition. With Seventy-six Illustrations after AlBERT DÜRER, HolbeiN, and other Masters. Crown 8vo, cloth, 2s. nett ; leather, $3 \mathrm{~s}$. ; and in velvet leather in box, 5s. nett.

HOLLAND, CLIVE.

Things Seen in Japan. With Fifty beautiful illustrations of Japanese life in Town and Country. Small 4to, cloth, 2s. nett; leather, 3s. nett; in box, in velvet leather, 5 s. nett.

HOW, W. W.

Hannibal, and the Great War between Rome and Carthage. 2s.

HUTCHINSON, Rev. H. N.

The Story of the Hills. A Popular Account of Mountains and How They were Made. With many Illustrations. Crown 8vo, 5 s.

HUTTON, C. A.

Greek Terracotta Statuettes. With a Preface by A. S. MurRay, LL.D. With Seventeen Examples printed in Colour and Thirty-six printed in Monochrome. 5s. nett ; or cloth, 7s. nett.

JAMES, CAIRNS.

The Golden Reciter. With an Introduction by CaIrns James, Professor of Elocution at the Royal Academy of Music, \&c. With Selections from Rudyard Kipling, Thomas Hardy, R. I. Stevenson, Seton Merriman, H. G. Wells, Christina Rossetti, Anthony Hope, Austin Dobson, Maurice Hewlett, Conan Doyle, \&્c. \&c. Extra crown 8vo, 704 pp. Cloth, 3s. 6d., and thin paper edition in cloth with gilt edges, 5s. Courier.

"A more admirable book of its kind could not well be desired." - Liverpeol

The Golden Humorous Reciter. Edited, and with a Practical Introduction, by Cairns James, Professor of Elocution at the Royal College of Music and the Guildhall School of Music. A volume of Recitations and Readings selected from the writings of F. Anstey, J. M. Barrie, S. R. Crockett, Jerome K. Jerome, Barry Pain, A. W. Pinero, Owen Seaman, G. B. Shaw, Ecc. \&cc. Extra crown 8vo, over 700 pages, cloth, 3s. 6d.; also a thin paper edition, with gilt edges, $5 \mathrm{~s}$.

JOY, BEDFORD.

A Synopsis of Roman History. Crown 8vo, 2s.

KEANE, Prof. A. H. (See Frobenius.) 


\section{Seeley $\otimes^{\circ}$ Co Limited}

\section{LANG, ANDREW.}

Oxford. New Edition. With 50 Illustrations by J. H. LORIMER, R.S.A., T. Hamilton Crawrord, R.S.W., J. Pennell, A. Brunet-Drbaines, A. Toussaint, and R. Kent Thomas. Extra crown 8vo, 6s. Also Pocket Editiod, 2s. nett; leather, 35. Dett. Special yapp leather, full gilt, in box, 5 s. aett.

\section{LEE, SIDNEY.}

Stratford-on-Avon. From the Earliest Times to the Death of Shakespeare. New revised edition, with additional Illustrations. Extra crown 8vo, 6s. Pocket Edition, 2s. pett; leatber, 3s. nett; and in special yapp leather, full gilt, in box, 55 s. nets

LEFROY, W. CHAMBERS.

The Ruined Abbeys of Yorkshire. With many Illustrations by $A$. Brunit-Drbaines and H. Toussaint. Crown 8vo, cloth, 2s. nett; leather, 3 s. neir and 5s. nett.

LEGROS, ALPHONSE.

Six Etchings by Alphonse Legros. With a Biographical Note. Imperial 4 to, Es. nett.

LEYLAND, JOHN.

The Peak of Derbyshire. With Map, Etchings, and other Illustrations by Herbert Railton and Alrkis Dawson. New Edition, Crown 8vo, cloth, 2s,; leather, 3s.; velvet leather, in a box, 55 nett.

The Yorkshire Coast and the Cleveland Hills and Dales. With Etchings and other Illustrations. Crown 8vo, 7s 6d.

LOFTIE, Rev. W. J.

The Inns of Court and Chancery. With many Illustrations, chiefly by Hermert Railton. Crown 8vo, cloth, 2S, nett; leather, 3s, nett and 3s, nett.

Westminster Abbey. With Serenty-four Illustrations, chiefly by HrR BERT RaILTON. Large crown 8vo, 7s. 6d.

Whitehall. With many Illustrations. Super-royal 8ro, sewed, 2s. 6d. nett; half-linen, 35. 6d. nett.

MACKENZIE, Rev. W. B.

Married Life and the Dwellings of the Righteous. 3s. 6d, white silk, 7s. 6d.

MALLESON, Colonel G. B., C.S.I.

The Indian Muting. With Copper Plates and other Illustrations. Crown 8vo, 55.

The Refounding of the German Empire. With Portrait and Plans. Crowa 8ro, 5s.

\section{MINIATURE LIBRARY OF DEVOTION}

Little Volumes of Short Extracts from the Christian Fathers. With Decorative Title-page and Photogravure Frontispiece. $32 \mathrm{mo}$, cloth extra, each is. nett; leather, each 15. 6d. nett. Also Three Volumes in leather in case, 4s. 6d. nett. Also bound in white vellum with gilt edges, each volume in a box, 2s. nett.
I. Saint Augustine.
2. Jeremy Taylor.
3. Saint Chrysostom.
4. Bishop Andrewes.
5. John Keble. 8. Fénelon.
7. Canon Liddon.
9. William Law. 


\section{Seeley $\mathcal{\Theta}^{\circ}$ Co Limited}

\section{MINIATURE PORTFOLIO MONO- GRAPHS}

A New Edition in $16 \mathrm{mo}$. Most of the Volumes have been carefully revised by the Authors. Each Volume profusely Illustrated. Cloth, 2s. nett; leather, 3s. nett ; velvet leather, in box, 5s. nett.

Peter Paul Rubens. By R. A. M. Stevenson.

Japanese Wood Engravings. By Professor W. Anderson.

Josiah Wedgwood. By A. H. Church, F.R.S., Professor of Chemistry, Royal Academy of Arts. New \& Revised Edition.

D. G. Rossetti. By F. G. Stephens, One of the Seven Members of the Pre-Raphaelite Brotherhood.

The Early Work of Raphael. By Julia Cartwright (Mrs. Ady).

Fair Women in Painting and Poetry. By William SHaRp (Fiona Macleod).

Antoine Watteau. By Claude Phillips, Keeper of the Wallace Collection.

Raphael in Rome. By Julia Cartwright (Mrs. Ady).

The New Forest. By C. J. Cornish, Author of "Life of the Zoo," Erc. The Isle of Wight. By C. J. CORNisH.

Gainsborough. By Sir Walter ArMstrong, Keeper of the National Gallery of Ireland.

MITFORD, MARY RUSSELL.

Country Stories. With 68 Illustrations by Grorge Morrow. Crown $8 \mathrm{vo}$, cloth, gilt top, 2s. nett; also in leather, 3s. nett; and in special leather yapp, full gilt in box, $5 \mathrm{~s}$. nett.

MONKHOUSE, W. COSMO.

The Earlier English Water-Colour Painters. With many Illustrations. Crown 8vo, 6s.

MORIARTY, G. P.

Dean Swift. His Life and Writings. Cheaper Edition, with Two Portraits on Copper. 3s. $6 \mathrm{~d}$.

MOULE, Archieacon A. E.

New China and Old. Notes on the Country and People made during a Residence of Thirty Years. With Thirty Illustrations. New Eoition, Revised. Crown 8vo, 5s.

MOULE, Right Rev. H. C. G., D.D. (Bishop of Durham).

The Sacred Seasons. Readings for the Sundays and Holy Days of the Christian Year. With text printed in red and black throughout, and illuminated with specially drawn initial letters and other ornaments, and with twelve illuminated pages printed in three colours and gold after illuminations in manuscripts at the British Museum. Extra crown 8vo, 6s. nett; also white cloth, in box, 7s. 6d. nett.

At the Holy Communion. Helps for Preparation and Reception. Cloth, is.; leather, 2s. nett; calf, 4s. 6d.

Christ's Witness to the Life to Come. Crown Svo, 3s. 6d.

Cross and the Spirit, The. Studies in the Epistle to the Galatians. Foolscap 8vo, rs. 6d.

Grace and Godliness. Studies in the Epistle to the Ephesians. Crown

In the House of the Pilgrimage. Hymns and Sacred Songs. 2s. 6d. Imitations and Translations. Crown $8 v 0,2 s .6 \mathrm{~d}$. nett.

Jesus and the Resurrection. Expository Studies on St. John xx. and xxi. Third Edition, 2s. 6d.

Lord's Supper, The. By Bishop Ridley. Edited with Notes and a Life by the BISHop of DURhaM. Crown 8vo, 5s. 


\section{Seeley $\circledast^{\circ}$ Co Limited}

MOULE, Right Rev. H. C. G., D.D.-Continued.

Our Prajer Book. Short Chapters on the Book of Common Prayer. $16 \mathrm{ma}$, Is, ; leather, 2S, nett.

Pledges of His Love, The. Thoughts on the Holy Communion. I6mo, Is, leacher, 25. nett.

Prajers for the Home. A Month's Cycle of Morning and Evening Family Worship, with some Occasional Prayers. Crown 8va, 3s. $6 \mathrm{~d}$.

Prajers and Promises. Messages from the Holy Scriptures. 16mo, 1s.; leather, 2s. nett; celf, 4s. 6d.

The Secret of the Presence, and other Sermons. Crown 8ro, 3s. 6d.

Temptation and Escape. Short Chapters for Beginners in the Christian

Life $26 \mathrm{mo}$, is.; leather, 2s, nett.

Thoughts on Christian Sanctity. 16mo, cloth, Is. ; leather, 2s. nett.

Thoughts on Secret Prayer. I6mo, cloth, 1s.; leather, 2s. nett; calf, 4s. 6d.

Thoughts on the Spiritual Life. $16 \mathrm{mo}$, cloth, 1s.; leather, 2s. nett.

Thoughts on Union with Christ. 16mo, cloth, Is.; leather, 2s. nett.

MURRAY, A. S., LL.D.

Greek Bronzes. With Four Copper Plates and many other Illustrations.

Super-royal 8ro, sewed, 35. 6d. nett; cloth, 4s. 6d. nett.

Greek Bronzes, by Dr. Murray, and Greek Terracotta Statuettes, by

C. A. Hurros. With Four Photogravures, Eight Coloured Plates, and Seventy-seven orber Illustrations In one Volume. Super-royal 8vo, cloth, zos 6d, nett.

NETTLESHIP, J. T.

Morland, George. With Six Copper Plates and Thirty other Illustrations.

Saper-5oyal 8ro, sewed, ss. nett; cloth, 6s. nett.

\section{THE NEW ART LIBRARY}

EDITED BY M. H. SPIELMANN, F.S.A., \& P. G. KONODY.

VOL. I.

THE PRACTICE OF OIL PAINTING AND DRAWING.

By Solomon J. Solomos, R.A. With Eighty Illustrations. 6s. nett.

VOL, II.

HUMAN ANATOMY FOR ART STUDENTS.

By Sir ALFRed Dowisg FrIPP, K.C.V.O., Lecturer upon Anatomy at

Guy's Hospital, London, and RaLPH Thompsos, Ch.M., F.R.C.S., with 2 chapter cn Comparative Anatomy, and Drawings by HARRY Dixos. With Ose hundred and fiftynine Photographs and Drawings. Square extra crown 8vo, 75. 6d, Dett.

VOI. III.

MODELLING AND SCULPTURE.

By ALBERT TOFT, A.R.C.A., M.S.B.S. With 1 ig Photographs and Drawings. Square extra crown 8 vo, 6s nett.

PAGE, J. LI. WARDEN.

Dartmoor, An Exploration of. With Map, Etchings, and other Illustrations Cheap Edition, 33. 6d.

Exmoor, An Exploration of. With Maps, Etchings, and other Illus. trations. Cheap Edition, 3s. 6d. 


\section{Seeley $\mathscr{G}$ Co Limited}

PENNELL, T. L., M.D., B.Sc., F.R.C.S.

Among the Wild Tribes of the Afghan Frontier. A Record of Sixteen Years' Close Intercourse with the Natives of the Indian Marches. With an Introduction by Field-Marshal Lord ROBgrts, V.C. Demy 8vo. With 37 Illustrations and a Map. I6s. nett.

PHILLIPS, CLAUDE.

The Earlier Work of Titian. With many Illustrations. Super-royal 8vo, sewed, 3s. 6d, nett ; cloth, 4s. 6d. nett.

The Later Work of Titian. With many Illustrations. Super-royal 8vo, sewed, 3s. 6d. nett ; cloth, 4s. 6d. nett.

Titian, a Study of his Life and Work. With Eight Copper Plates and many other Illustrations. Super-royal 8vo, 9s. nett.

The Picture Gallery of Charles I. With many Illustrations. Superroyal $8 \mathrm{vo}$, sewed, 35. $6 \mathrm{~d}$. nett ; cloth, 45. 6d. nett.

Frederick Walker. Sup.-roy.8vo, sewed, 2s. 6d. nett; half-linen, 3s.6d.nett. Antoine Watteau. Sup.-roy. 8vo, sewed, 2s.6d.nett; half-linen, 3s.6d. nett; also small 4 to, clotb, $2 s$. nett; and 3 s. and 5 s. nett in leather.

POLLARD, A. W.

Italian Book Illustrations. Super-royal 8vo, sewed, 2s. 6d. nett ; half-linen, 3s. 6 d. nett.

\section{PORTFOLIO MONOGRAPHS ON ARTISTIC SUBJECTS}

"A triumph of magnificent illnstration and masterly editing."-The Times.

With many Illustrations, some in colours. Super-royal $8 \mathrm{vo}$, 55. nett, and in cloth, 75. nett. Many of the Volumes are issued in two forms and at various nett prices. Where two prices are given, the first is that of the paper cover edition; the second that of the cloth. When only one price is given, the Volume is bound in paper only.

ANDERSON, Prof. W.

Japanese Wood Engravings. 25. 6d. and 35. 6d.

ARMSTRONG, Sir WALTER.

The Art of Velazquez. 3s. 6 d.

The Life of Velazquez. 3s. 6d.

The Peel Collection and the Dutch School of Painting. 5s. and 7s.

Thomas Gainsborough. Half-linen, 3s. 6d.

W. Q. Orchardson. 2s. 6d. and 3s. 6d.

BEDFORD, W. K. R.

Malta. 2s. 6d.

BENHAM, Canon, and CHARLES WELCH, F.S.A.

Medizval London. 3s. 6d., 5s., and $7 \mathrm{~s}$.

The Tower of London. 5s. and 7s.

BENHAM, Canon.

Old St. Paul's Cathedral. 5s. and 7s.

BINYON, LAURENCE.

Dutch Etchers of XVIIth Century. 2s. 6d. and 3s. 6d. John Crome and J. S. Cotman. 3s. $6 \mathrm{~d}$. 


\section{Seeley $\circledast^{\circ}$ Co Limited}

BIRCH, G. H., F.S.A. London on Thames. 5s. and 75 .

CARTWRIGHT, JULIA (MrS. ADY).

Jules Bastien-Lepage. 2s. 6d. and 35. 6d.

The Early Work of Raphael. 2s. 6d. and 3s. 6d.

Raphael in Rome. 2s. 6d. and 35. 6d.

CHURCH, A. H., F.R.S.

Josiah Wedgrood. 5s. and 7s.

CORNISH, C. J.

The Isle of Wight. 2s. 6d. and $35.6 \mathrm{~d}$.

The New Forest. 2s. 6d. and 3s. 6d.

CUST, LIONEL, F.S.A.

The Engravings of Albert Dürer. 2s. 6d. and 3s. $6 \mathrm{~d}$.

The Paintings and Drawings of Albert Dürer. 35. 6d.

DAVENPORT, CYRIL, F.S.A.

Royal English Bookbindings. 3s. 6d, and 4s. $6 \mathrm{~d}$.

Cameos. 55. and 7s.

DAVIES, RANDALL, F.S.A.

English Society of the Eighteenth Century in Contemporary Art.

DESTREE, O. G.

The Renaissance of Sculpture in Belgium. 2s. $6 \mathrm{~d}$. and $3 \mathrm{~s} .6 \mathrm{~d}$.

FLETCHER, W. $Y$.

Bookbinding in France. 25. 6d. and 35. 6d.

GARDNER, J. STARKIE.

Armour in England. 35. 6d.

Foreign Armour in England. 35.6d.

GARNETT, RICHARD, C.B., LL.D.

Richmond on Thames. 3s. 6d. and 4s. 6d.

GRAHAME, GEORGE.

Claude Lorrain. 2s.6d. and 35. 6d.

HAMERTON, P. G.

The Etchings of Rembrandt. 2s. $6 \mathrm{~d}$, and $35.6 \mathrm{~d}$

HUTTON, C. A.

Greek Terracotta Statuettes. 5s. and 75.

LOFTIE, W. J.

Whitehall. 2s. 6d. and 3s. 6 d.

MURRAY, A. S., LL.D.

Greek Bronzes. 35. 6d. and 4s. 6d.

NETTLESHIP, J. T.

George Morland. 55 and 65.

PHILLIPS, CLAUDE.

Frederick Walker. 2s. 6d. and 3s. $6 \mathrm{~d}$.

Antoine Watteau. 2s. 6d. and 3s. 6d.

The Picture Gallery of Charles 1. 3s. $6 \mathrm{~d}$.

The Earlier Work of Titian. 3s. 6d.

The Later Work of Titian. 35.6d.

POLLARD, ALFRED W.

Italian Book Illustrations. 2s. $6 \mathrm{~d}$. and $3 \mathrm{~s} .6 \mathrm{~d}$.

PRIOR, E. S., F.S.A.

The Cathedral Builders in England. 5s. and 7s. 


\section{Seeley $\mathscr{\sigma}^{\circ}$ Co Limited}

SHARP, WILLIAM.

Fair Women. 2s. 6d. and 3s. 6d.

STEPHENS, F. G.

Dante Gabriel Rossetti. 2s. 6d.

WEALE, W. H. JAMES.

STEVENSON, R. A. M.

Peter Paul Rubens. 3s. 6d.

WAERN, CECILIA.

John La Farge. 3s. 6d.

Gerard David, Painter and Illuminator. 2s. 6d. and 35. $6 \mathrm{~d}$.

PRIOR, E. S., F.S.A.

The Cathedral Builders of England. Illustrated. Super-royal 8vo, sewed, 5 s. nett; cloth, extra gilt top, 75 . nett.

QUILLER COUCH, A. T.

The Pilgrims' Way. A Little Scrip for Travellers. In Prose and Verse. With end papers in colour, and gilt top. Fcap. 8 vo, cloth, 3s. 6d. nett; on thin paper, leather, 5s. nett.

REYNOLDS, Sir JOSHUA.

Discourses Delivered to the Students of the Royal Academy. With an Introduction and Notes by RoGBR FRY. With Thirty-Three Illustrations. Square extra Crown 8vo, 7s. 6d. nett.

ROCHE, C. E.

Things Seen in Holland. With Fifty Illustrations. Small 4to, cloth, 2 . nett; lambskin, 3s. nett ; velvet leather, 5 s. nett.

ROPES, A. R.

Lady Mary Wortley Montagu. With Eight Illustrations. Crown 8 vo, cloth, 2s. 6d. nett.

RUSSELL, W. CLARK.

The British Seas. With upwards of Fifty Illustrations. Crown 8ro, cloth, 2s. ; leather, $3 \mathrm{~s}$. ; special yapp leather in box, $5 \mathrm{~s}$. nett.

SANDBY, W.

Thomas and Paul Sandby, Royal Academicians. Their Lives and Works. With many Illustrations. Crown 8vo, 7s. $6 \mathrm{~d}$.

SANDERSON, E.

Great Britain in Modern Africa. With Four Portraits on Copper and a Map. Crown 8vo, 5 s.

SCOTT-ELLIOT, Professor G. F., M.A., B.Sc.

Botany of To-day. With Twenty-seven Illustrations. Large crown 8vo, 5s. nett.

\section{SCIENCE OF TO-DAY SERIES}

The volumes of this series give an attractive, lucid, yet at the same time scientifically accurate account of various subjects in non-technical language. Large crown $8 \mathrm{vo}$, $5 \mathrm{~s}$. nett.

Aerial Navigation of To-day. By Charles C. Turner.

Astronomy of To-Day. By C.G. Dolmage, M.A., LL.D., D.C.L., F.R.A.S. Botany of To-day. By Prof. G. F. ScotT-Elliot, M.A., B.Sc.

Electricity of To-Day. By Charles R. Gibson, F.R.S.E.

Scientific Ideas of To-Day. By CharLes R. Gibson, F.R.S.E.

Engineering of To-day. By Thomas W. Corbin.

\section{SEELEY'S ILLUSTRATED POCKET LIBRARY}

Crown $8 \mathrm{vo}$, cloth, gilt edge, 2s. nett; also in leather, 3 s. nett; and

yapp leather in box at 5 s.

ADDISON and STEELE.

The Spectator in London. With Fifty-six Illustrations by RALPH Cleaver, and Headpieces by W. A. Atrin Berky, Clovgr Bromley, \&c. 


\section{Seeley $\&^{\circ}$ Co Limited}

CLARK, J. W., Registrary of the University of Cambridge.

Cambridge. With many Illustrations.

GODLEY, A. D.

Aspects of Modern Oxford. With many Illustrations.

HAMERTON, P. G.

Paris. With many Illustrations.

LEE, SIDNEY.

Stratford-on-Aron. From the Earliest Times to the Death of Shakespeare. With 52 Illustrations by HrRBERT RAILTON and E. HULL.

MITFORD, MARY RUSSELL.

Country Stories. With 68 Illustrations by George MoRrow.

HERBERT, GEORGE.

The Temple. Sacred Poems and Ejaculations. The Text reprinted from the first edition. With 76 Illustrations after DURER, HOLBziN, and other Masters.

LANG, ANDREW.

Oxford. With 40 Illustrations by various artists.

LEFROY, W. CHAMBERS.

The Ruined Abbeys of Yorkshire. With many Illustrations.

LEYLAND, JOHN.

The Peak of Derbyshire : its Scenery and Antiquities.

LOFTIE, W. J.

The Inns of Court. With 60 Illustrations.

RUSSELL, W. CLARK.

British Seas. With 50 Illustrations by J. C. Hook, R.A., HAMILTON MacCallum, Colin Honter, \&c.

STEVENSON, R. L. Edinburgh. With many Illustrations by $T$. HAMilton CRAivford, R.S.A. (This volume is only to be had in this series in leather, 5s. nett. For other editions of this book, see next page.)

\section{THE STANDARD LIBRARY}

Extra Crown 8vo, With many Illustrations. Price 2s. 6d. nett. Lady Mary Wortley Montagu. By A. R. Ropes.

Mrs. Thrale. By L. B. SezLey.

Round My House. By P. G. Hamerton.

Fanny Burney \& Her Friends. By L. B. Seeley.

SEELEY, Sir J. R.

Goethe Reviewed after Sixty Years. With Portrait. Crown 8vo, 3s. 6d. A Short History of Napoleon the First. With Portrait. Crown Svo, $5 \mathrm{~s}$. SEELEY, Sir J. R., and Dr. ABBOTT.

English Lessons for English People. Crown 8ro, 4s. 6d.

SEELEY, L. B.

Mrs. Thrale, afterwards Mrs. Piozzi. With Eight Illustrations. Crown 8vo, 2s. 6d nett.

Fanny Burney and her Friends. With Eight Illustrations. Crown 8 vo. 2s. $6 \mathrm{~d}$ nett.

SHAND, A. INNES.

General John Jacob. Commander of the Sind Irregular Horse, and Founder of Jacobabad. With many 1llustrations. Demy 8vo, 6s.

The War in the Peninsula. With Portraits and Plans. $5 \mathrm{~s}$.

SHARP, WILLIAM.

Fair Women. Illustrated. Super-royal 8vo, sewed, 2s. 6d. nett; half-

linen, 3s. 6d. nett. Also new edition, small 4to, cloth, 2s. nett; leather, $3 \mathrm{~s}$. nett.

SHIPLEY, M. E.

Daily Help for Daily Need. A Selection of Scripture Verses and Poetry for Every Day in the Year. Crown 8vo, 4s. 6d. 


\section{Seeley $\&$ Co Limited}

SOLOMON, SOLOMON J., R.A.

The Practice of Oil Painting and Drawing. Illustrated with many Drawings by the Author, and by Paintings.

STEPHENS, F. G.

Rossetti, D. G. Super-royal 8vo, sewed, 2s. 6d. nett ; also small 4to, cloth, 2s. nett ; leather, 3s. nett ; velvet leather, in a box, 5s. nett.

STEVENSON, R. L.

Edinburgh. Fcap. 8vo, with Frontispiece, gilt top, cloth, 2s. nett; leather, 35. nett. Crown 8vo, Illustrated, cloth, 35. 6d. Roxburgh, gilt top, 5s. Library Edition. Crown $8 v 0$, buckram, dark blue, gilt top, Sixteen Full-page Illustrations, $6 s$. Presentation Edition. Extra crown 8vo, with Sixty-four Illustrations, 6s. nett; also People's Edition, demy $8 v 0,6$ d. nett.

STEVENSON, R. A. M.

Rubens, Peter Paul. Illustrated. Super-royal 8vo, 3s. 6d. nett, sewed. also small, 4 to, cloth, 2s. nett ; leather, $3 \mathrm{~s}$. nett and $5 \mathrm{~s}$. nett.

STIGAND, Captain C, H., F.R.G.S., F.Z.S.

To Abyssinia Through an Unknown Land. With Thirty-six Illustrations and Two Maps. Demy 8vo, 16s. nett.

SWANN ALFRED J.

Fighting the Slave Hunters in Central Africa. With Forty-five Illustrations and 2 Map. Demy 8vo, x6s. nett.

\section{"THINGS SEEN" SERIES}

Each volume with 50 Illustrations. Small 4to, cloth, 2s. ; leather, 35. ; and velvet leather, in a box, $5 \mathrm{~s}$. nett.

Things Seen in Japan. By Clive Holland.

Things Seen in China. By J. R. Chrtry.

Things Seen in Egypt. By E, L. BuTcher.

Things Seen in Holland. By C. E. Roche.

Things Seen in Spain. By C. Gasquoine Hartley.

TOFT, ALBERT, Hon., A.R.C.A., M.S.B.S.

Modelling and Sculpture. Profusely Illustrated with II9 Photographs and Drawings. Square extra crown 8vo, 6s. nett.

TOWNSHEND, Captain A. T.

A Military Consul in Turkey. With many Illustrations. Demy 8vo, I6s. nett.

TURNER, CHARLES C.

Aerial Navigation of To-day. With Seventy Illustrations and Diagrams. Extra crown 8 vo, 5 s. nett.

WACE, Very Rev. H., Dean of Canterbury.

The Sacrifice of Christ. Its Vital Reality and Efficacy. Cloth, Is.

WAERN, C.

John La Farge. Illustrated. Super-royal 8vo, sewed, 35. 6d. nett.

WEALE, W. H. JAMES.

Gerard David, Painter and Illuminator. Illustrated. Super-royal 8vo, sewed, 2s. 6d. nett; half-linen, 3s. 6d. nett.

WELCH, C., and Canon BEN HAM.

Medizval London. With a Frontispiece in Photogravure, Four Plates in Colour, and many other Illustrations. Super-royal 8vo, sewed, 5s. nett; cloth, gilt top, 75. nett. Also extra crown 8vo, 3s. 6 d. nett.

WICKS, MARK.

To Mars via the Moon. An Astronomical Story. With Sixteen Illustrations and Diagrams. Extra crown 8vo, 5s. 
() $\quad 5 y^{5} \leq 7 x$

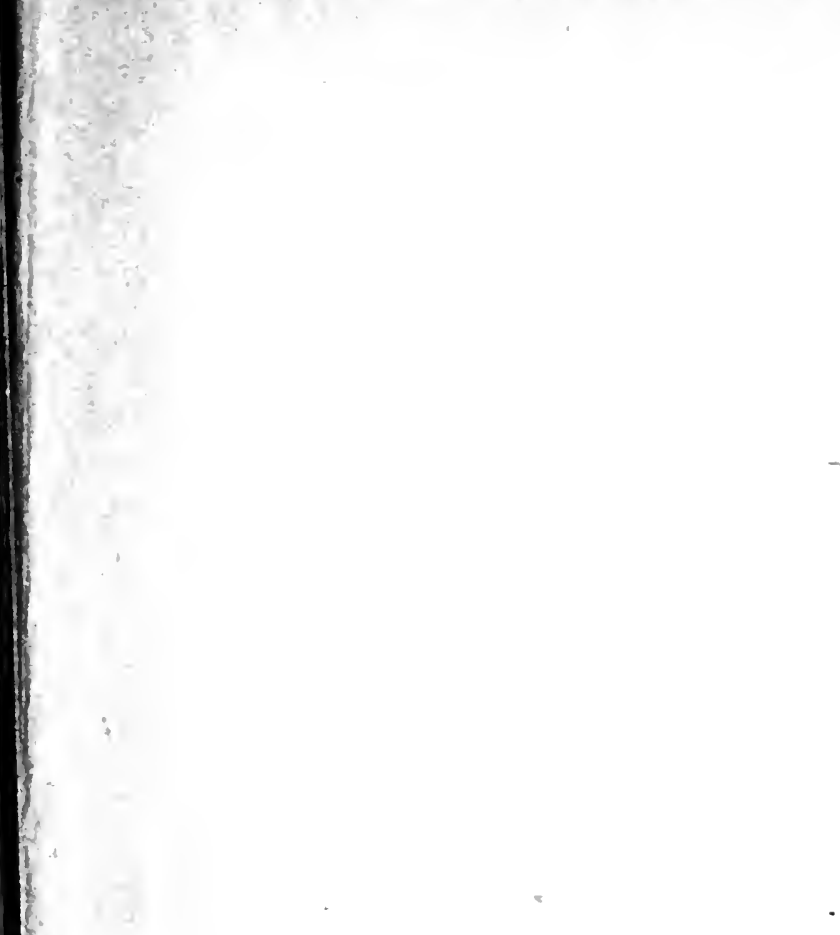





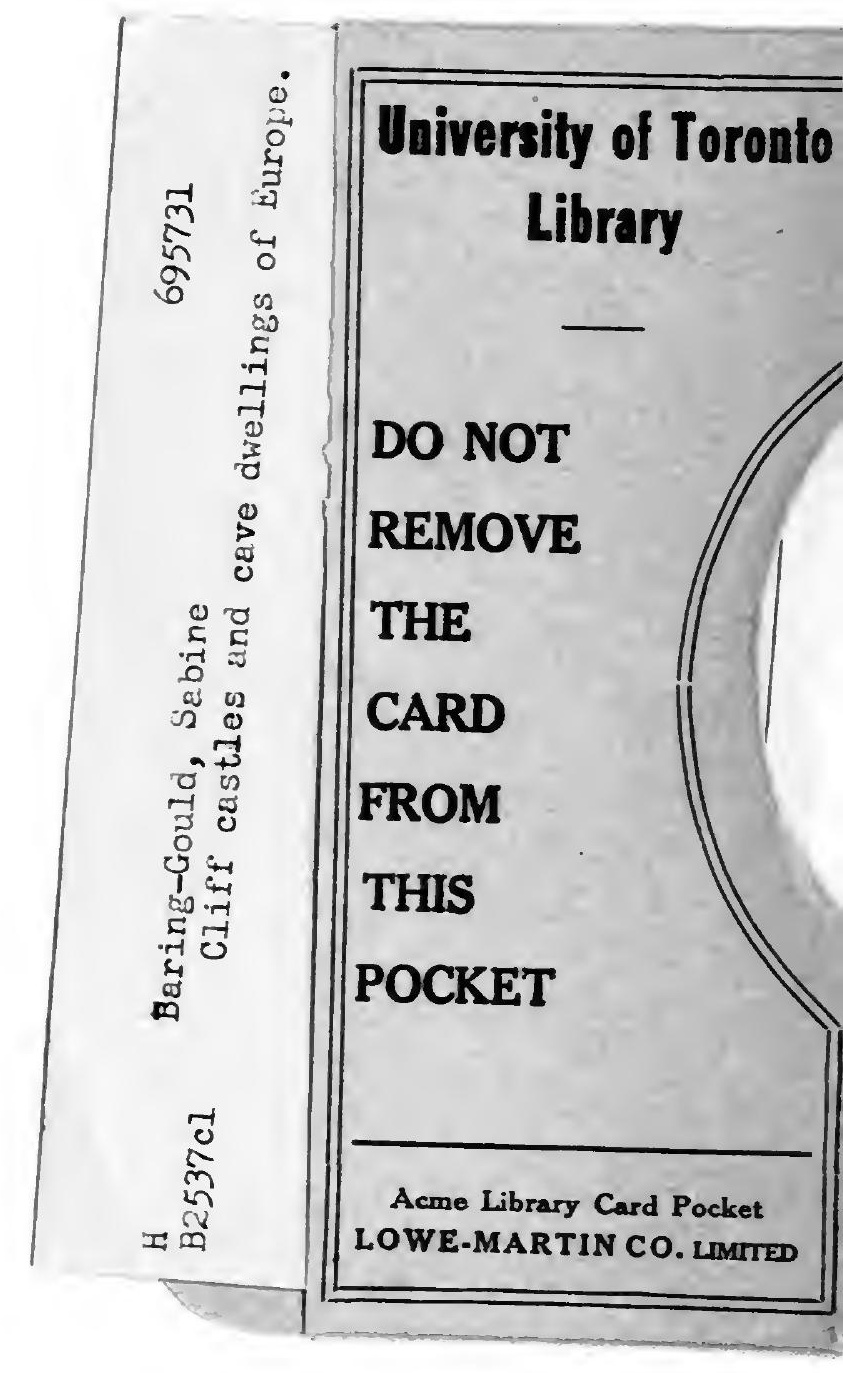


